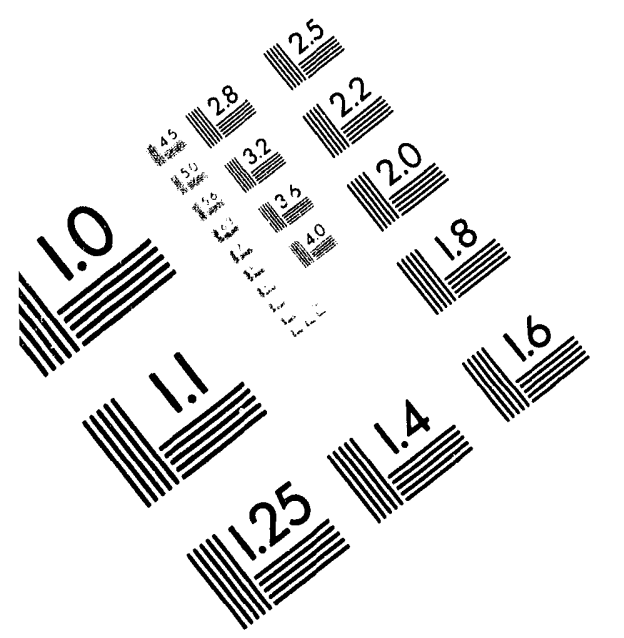

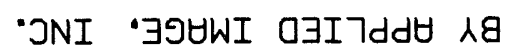

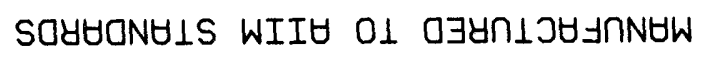
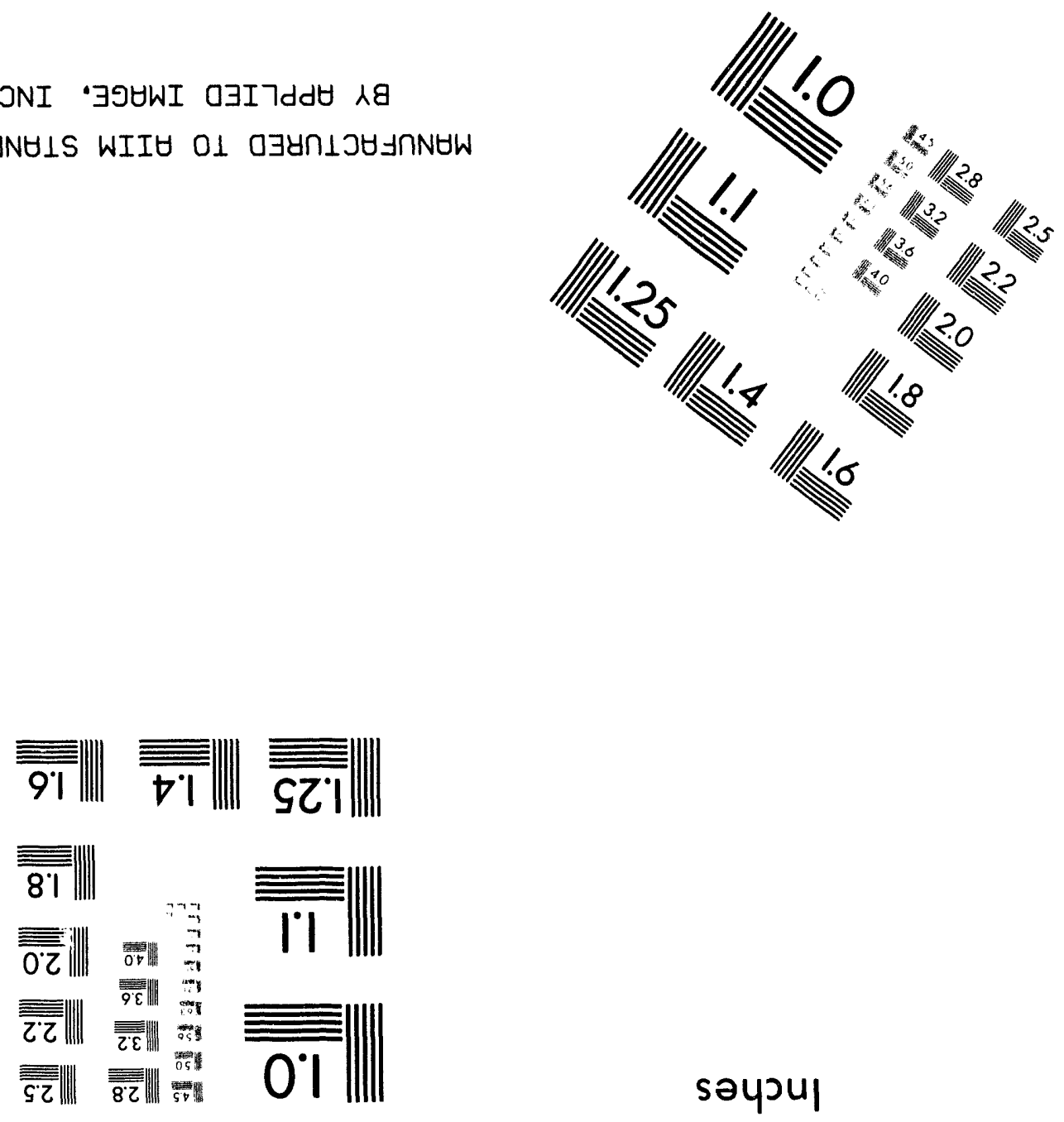

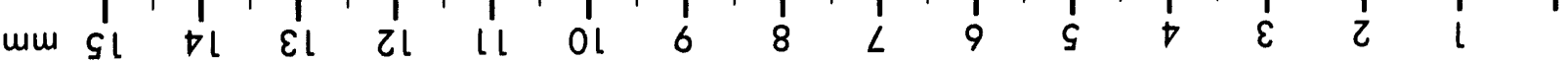
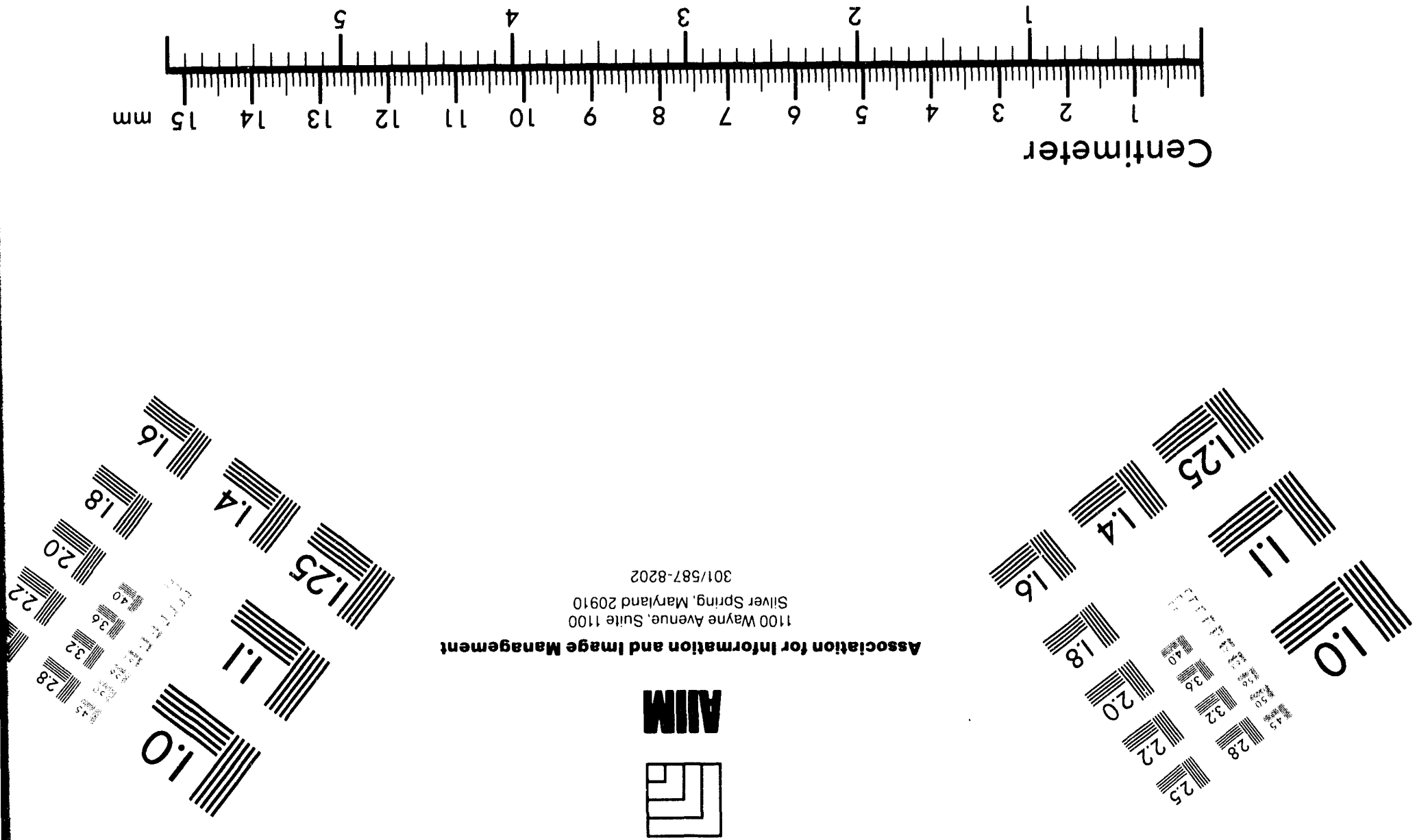
$\nabla$
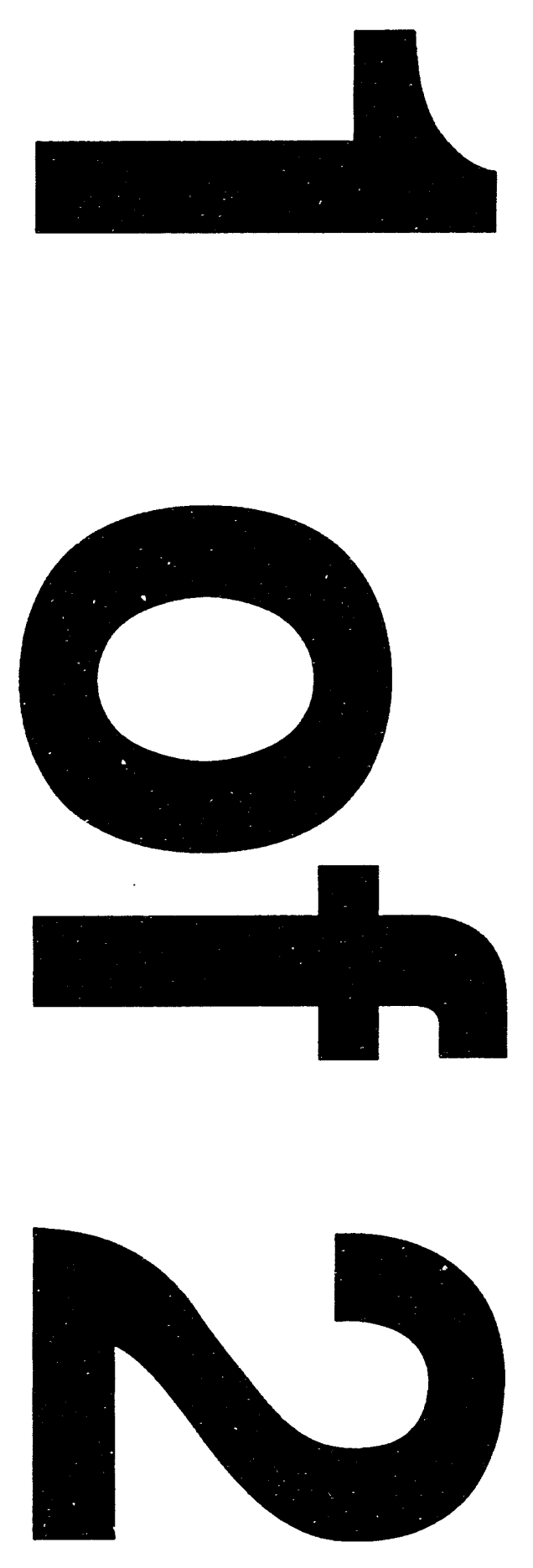

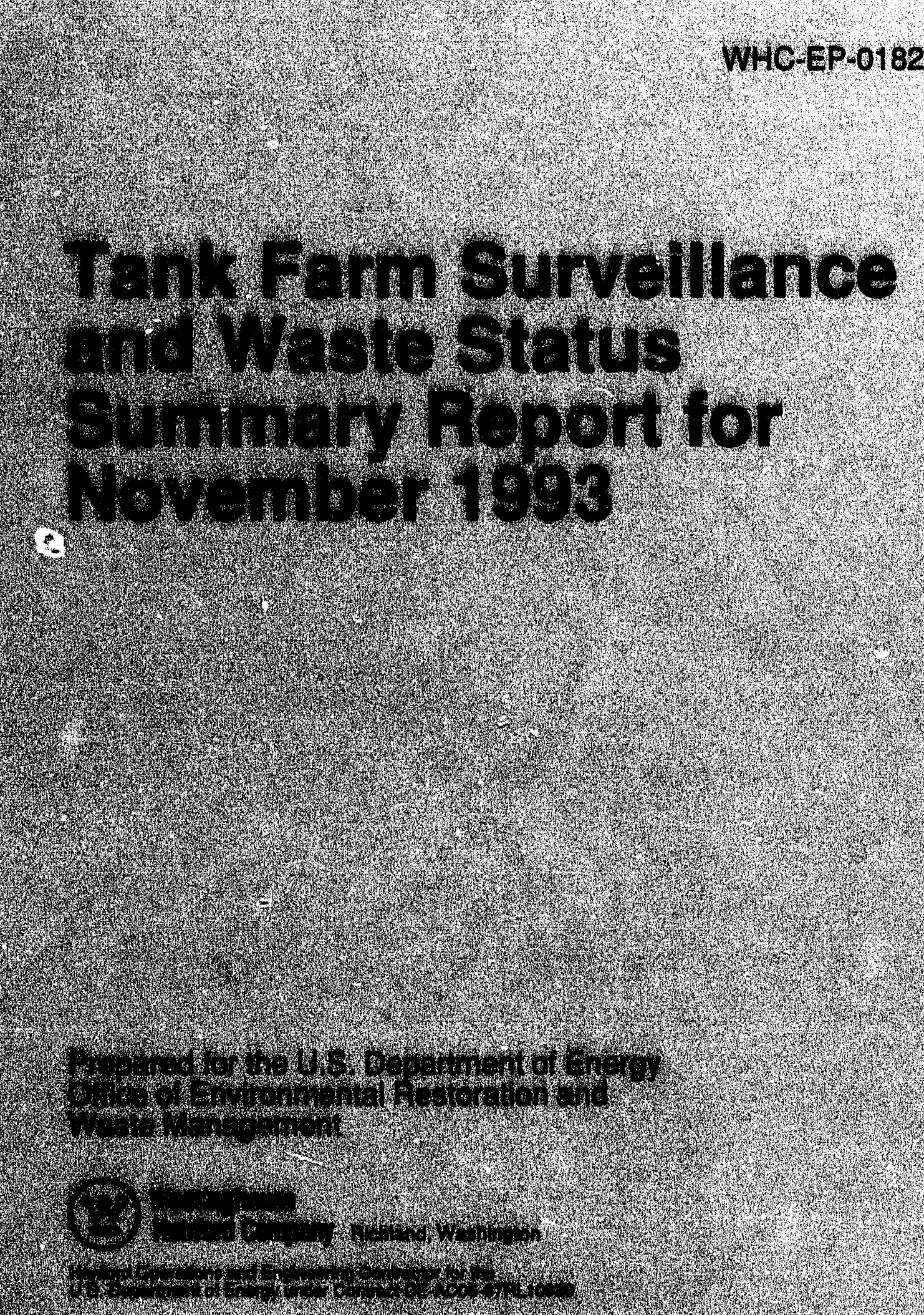

7x+7x 
1.4.

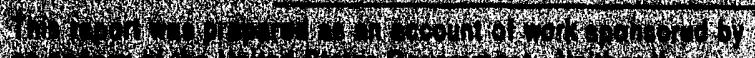
1.

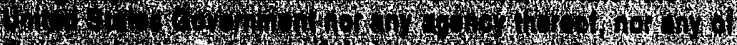
- 3 .

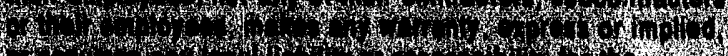

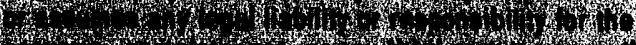

H. 1 (1) * 1 (1) (4.7.t.

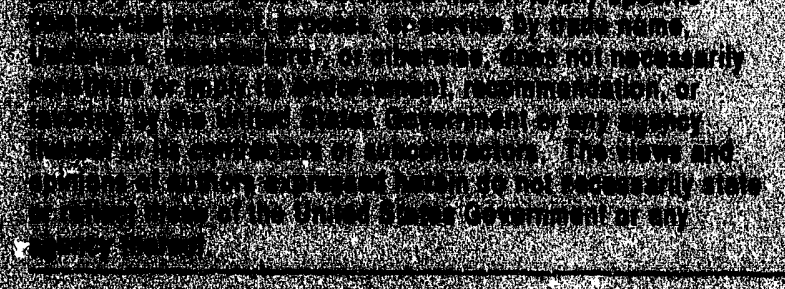

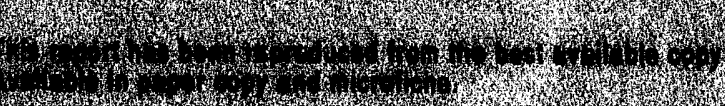

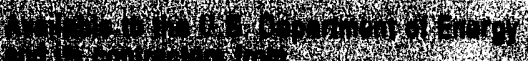

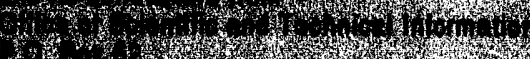 \\ $5,4,1,1$}

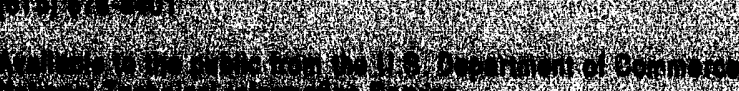

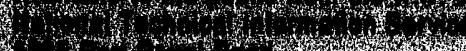

$14,1,+3$

\section{t.}

1. 


\title{
Tank Farm Surveillance and Waste Status Summary Report for November 1993
}

\author{
B. M. Hanlon
}

Date Published

February 1994

Prepared for the U.S. Department of Energy Office of Environmental Restoration and Waste Management

\footnotetext{
(2) Westinghouse P.O. Box 1970

Hanford Company Richland, Washington 99352

Hanford Operations and Engineering Contractor for the

U.S. Department of Energy under Contract DE-AC06-87RL10930
}

Approved for Public Release 
WHC-EP-0182-68

\section{APPROVAL}

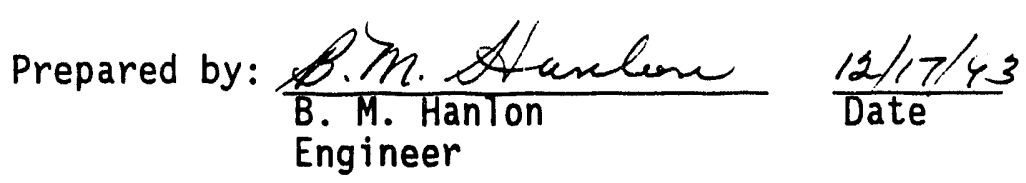

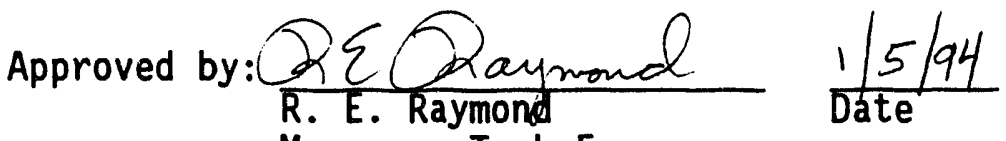

$$
\begin{aligned}
& \text { Manager, Tank Farms } \\
& \text { Plant Engineering }
\end{aligned}
$$




\begin{tabular}{|c|c|c|c|}
\hline Date Received: & थार्द & INFORMATION RELEASE REQUEST & $\begin{array}{l}\text { Reference: } \\
\text { WHC-CM-3-4 }\end{array}$ \\
\hline
\end{tabular}

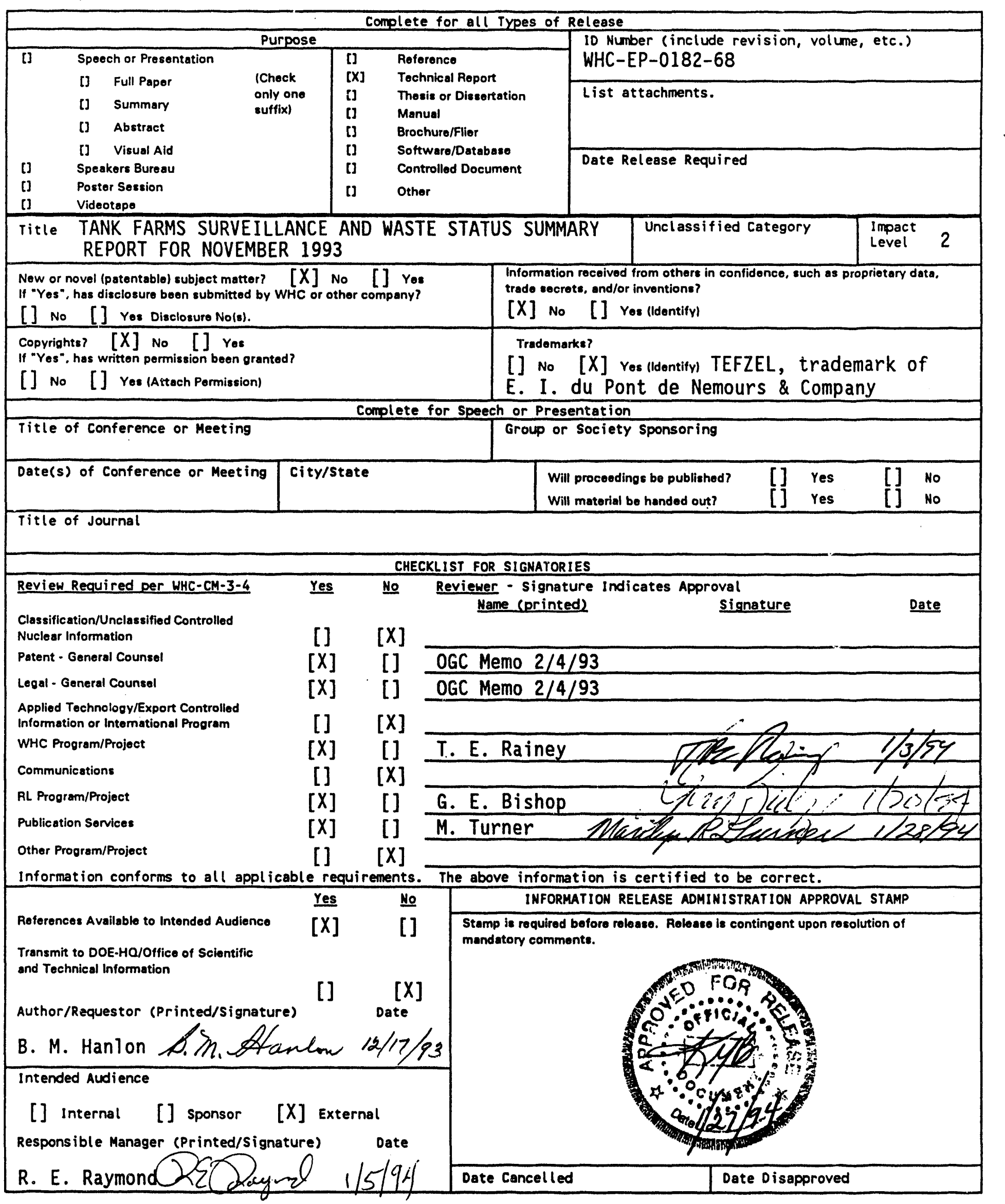




\title{
TANK FARM SURVEILLANCE AND WASTE STATUS \\ SUMMARY REPORT FOR NOVENBER 1993
}

\author{
B. M. Hanlon
}

\begin{abstract}
This report is the official inventory for radioactive waste stored in underground tanks in the 200 Areas at the Hanford Site. Data that depict the status of stored radioactive waste and tank vessel integrity are contained within the report. This report provides data on each of the existing 177 large underground waste storage tanks and 49 smaller catch tanks and special surveillance facilities, and supplemental information regarding tank surveillance anomalies and ongoing investigations. This report is intended to meet the requirement of $U$. S. Department of Energy-Richland Operations office Order 5820.2A, Chapter I, Section 3.e. (3) (DOE-RL, 1990, Radioactive Waste Management, U.S. Department of Energy-Richland Operation Office, Richland, Washington) requiring the reporting of waste inventories and space utilization for Hanford Tank Farm Tanks.
\end{abstract}




\section{WHC-EP-0182-68}

This page intentionally left blank. 
WHC-EP-0182-68

CONTENTS

SUMMARY . ...................... 1

I. WASTE TANK STATUS .................... 1

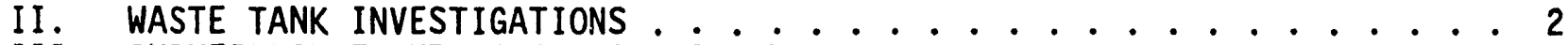

III. SURVEILLANCE AND WASTE TANK STATUS HIGHLIGHTS . . . . . . . . . 7

Apperdixes:

A. WASTE TANK SURVEILLANCE MONITORING TABLES ............ A-1

Tables:

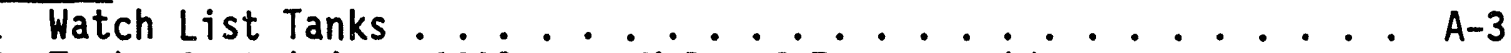

2 Tanks Containing $>1000$ Gram Mole of Ferrocyanide . . . . . . A-5

3 Tanks With Potential for Hydrogen or Flammable Gas

Accumulation above the Flammability Limit . . . . . . . . A-7

4 Single-She11 Tanks Containing Concentrations of Organic Salts . A-8

5 Single-Shell Tanks With High Heat Loads $(>40,000 \mathrm{Btu} / \mathrm{h}) \ldots$. . A-10

6 Non-Watch List Low Heat List Tanks $(<40,000 \mathrm{Btu} / \mathrm{h})$. . . . . . A-12

7 Single-Shell Tanks Monitoring Compliance Status . . . . . . A-15

8 Double-Shell Tanks Monitoring Compliance Status ...... . A-20

9 Automatic Food Instrument Corporation (FIC) Gauges

Fiqures:

Out of Service ................ . A-22

1 Discrepancy Report Status ................ A-23

2 Discrepancy Report Cumulative Total ............. A-24

3 Discrepancy Report Status by Age . . . . . . . . . . . A-25

B. DOUBLE-SHELL TANK WASTE TYPE AND SPACE ALLOCATION . . . . . . . B-1

Tables:

1 Double-She11 Tank Waste Type and Space Allocation ....... B-3

2 Double-Shel1 Tank Waste Inventory ........... B-14

Figures:

1 Current Status and Contingency Space for the 242-A

Evaporator Restart .......... . . . . B-4

2 Total Available Usable Tank Space . . . . . . . . . . . B-5

3 Priority Space Availablity and Usage ........... . B-6

4 Comparison of Monthly Average Waste Generation to

Management Limit by Facility . . . . . . . . . . B-7

5 PUREX Monthly Waste Generations ............... B-8

6 Talik Farm Monthly Waste Generations . . . . . . . B-9

7 B Plant Monthly Waste Generations .............. B-10

8 T Plant Monthly Waste Generations ............. B-11

9 S Plant Monthly Waste Generations ............. B-12

10300 Area Monthly Waste Generations . . . . . . . . . . . . B-13

C. TANK AND EQUIPMENT CODE AND STATUS DEFINITIONS ........... c-1

1 Tank and Equipment Code/Status Definitions ......... C-3 


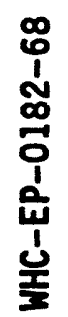

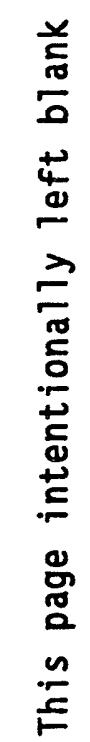


D. TANK FARM CONFIGURATION, STATUS AND FACILITY CHARTS . . . . . . . . . D-1 Figures:

I High-Level Waste Tank Configuration . . . . . . . . . . D-3

2 Double-Shel1 Tank Instrumentation Configuration . . . . . . D-4

3 Single-Shell Tank Instrumentation Configuration . . . . . . D-5

4 Double-Shell Tank Status . . . . . . . . . . . . D-7/8

5200 E Single-Shell Tank Status . . . . . . . . . . . . D-9/10

$6200 \mathrm{~W}$ Single-Shell Tank Status . . . . . . . . . . . . . D-11/12

7 Hanford Tank Farms Facilities Chart: 200-West Area . . . . . D-13/14

8 Hanford Tank Farms Facilities Chart: 200-East Area . . . . . . D-15/16

E. MONTHLY SUMMARY . . . . . . . . . . . . . . . . E-1 Tables:

l Monthly Summary . . . . . . . . . . . . . . . E-3

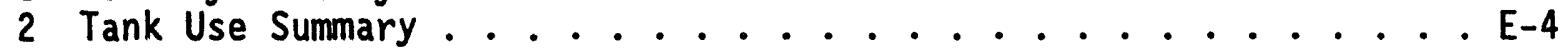

3 Inventory Summary by Tank Farm . . . . . . . . . . E-5

4 Inventory and Status by Tank - Double-Shell Tanks ........ E-6

5 Inventory and Status by Tank - Single-Shell Tanks . . . . . . E-9

F. PERFORMANCE SUMMARY .................... F-1 Table:

1 Performance Summary . . . . . . . . . . . . . F-3

G. PUMPING RECORD/LIQUID STATUS AND PUMPABLE LIQUID REMAINING IN TANKS . . G-1 Tables:

1 Pumping Record . . . . . . . . . . . . G-3

2 Liquid Status and Pumpable Liquid Remaining in Tanks . . . . G G-4

H. CATCH TANKS AND SPECIAL SURVEILlanCE FACILITIES . . . . . . . . H-1

\section{Tables:}

1 East and West Area Catch Tanks and Special

Surveillance Facilities (Active) . . ......... H-3

2 East Area Catch Tanks and Special Surveillance

Facilities (Inactive) ............. . . H-4

3 West Area Catch Tanks and Special Surveillance

Facilities (Inactive) .................. H-5

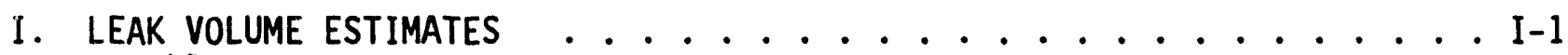
Table:

I Single-Shell Tank Leak Volume Estimates . . . . . . . . . I-3

J. INTERIM STABILIZATION STATUS . . . . . . . . . . . . J-1 Table:

$\frac{7 a b l e}{1}$ Single-Shell Tanks Interim Stabilization Status ....... J-3 


\begin{tabular}{|l|c|c|}
\hline \multicolumn{3}{|c|}{ METRIC CONVERSION CHART } \\
\hline 1 inch & $=$ & 2.54 centimeters \\
\hline 1 foot & $=$ & 30.48 centimeters \\
\hline 1 gallon & $=$ & 3.80 liters \\
\hline 1 ton & $=$ & 0.90 metric tons \\
\hline${ }^{\circ} \mathrm{F}=\left(\frac{9}{5}{ }^{\circ} \mathrm{C}\right)+32$ \\
\hline \multicolumn{1}{|c|}{$\begin{array}{c}\text { Btu/h }=2.930711 \text { E-01 watts } \\
\text { (International Table) }\end{array}$} \\
\hline
\end{tabular}


WHC-EP-0182-68

\section{TANK FARM SURVEILLANCE AND WASTE STATUS SUMMARY REPORT FOR NOVEMBER 1993 SUMMARY}

Note: Changes from the previous month are in bold print.

\section{WASTE TANK STATUS}

\begin{tabular}{|c|c|c|}
\hline Category & Quantity & Date of Last Change \\
\hline In-Service Tanks ${ }^{c}$ & 28 double-she 11 & $10 / 86$ \\
\hline Out-of-Service Tanks & 149 single-shell & $07 / 88$ \\
\hline Assumed Leaker Tanks ${ }^{\dagger}$ & 67 single-shell & 7/93 \\
\hline Sound Tanks & $\begin{array}{l}28 \text { double-shell } \\
82 \text { single-shell } \\
\end{array}$ & $\begin{array}{l}1986 \\
7 / 93 \\
\end{array}$ \\
\hline Interim Stabilized Tanks ${ }^{b, d}$ & 106 single-shell & $04 / 93$ \\
\hline Not Interim Stabilized ${ }^{f}$ & 43 single-shell & $04 / 93$ \\
\hline Intrusion Prevention Completed & 98 single-shell & $09 / 91$ \\
\hline $\begin{array}{l}\text { Watch List Tanks } \\
\text { Total }\end{array}$ & $\begin{array}{l}45 \text { single-she11 } \\
6 \text { double-she11 } \\
51 \text { tanks }\end{array}$ & $\begin{array}{l}8 / 93^{h} \\
6 / 93 \\
8 / 93\end{array}$ \\
\hline
\end{tabular}

although all 149 single-shell tanks were removed from service (i.e., no longer authorized to receive waste) as of November 21, 1980, the category of "Out-of-Service" was not established until July 1988.

b of the 106 tanks classified as interim stabilized, 59 are listed as assumed leakers. The total of 106 interim stabilized tanks includes six tanks that do not weet current establ ished supernatant and interstitial liquid stabilization criteria: B-104, B-110, B-111, T-102, T-112, and U-110. (The five tanks did meet the criteria in existence when they were declared interim stabilized). B-110, B-111, and U-110 are assumed leakers but surveillance data do not show an indication of a continuing (eak.)

C six double-shell tanks listed as "in service" are currently included on the Hydrogen Watch List and are thus prohibited from receiving waste in accordence with uSafety Measures for Haste Tanks at Hanford Nuclear Reservation," Section 3137 of the Mational Defense Authorization Act for Fiscal Year 1991, November 5, 1990, Public Law 101-510.

d of the 45 single-shell tanks on Watch Lists, 19 have been Interim Stabilized.

- of the 45 single-shell tanks on Watch Lists, 28 have completed Intrusion Prevention (this category replaced Interim Isolation). See Appendix C. Tank and Equipwent Codes and Status Definitions, for "Intrusion Prevention" definition.

f Eight of the tanks are both assumed leakers and not Interim Stabilized. See Appendix I, Leak Volume Estimates, for more details. Tank SX-102 was declared an essumed leaker in May, and.reclassified as Sound in July, 1993. See "Waste Tank Investigations" section of the July 1993 report for more details.

9 see Tables $A-1$ through $A-5$ for more information on Watch List Tanks. Three tanks are currently on more than one Watch List.

h Dates for the Watch List tanks are "officially added to the Watch List" dates. See Table A-1, Watch List Tanks, for further information. 


\section{WASTE TANK INVESTIGATIONS}

This section includes all single-shell tanks or catch tanks which are showing surface level or interstitial liquid level (ILL) decreases, or drywelll lateral radiation level increases.

There were no tanks under investigation for surface or ILL decreases or for drywell/lateral radiation increases during November 1993.

A. Assumed Leakers or Assumed Re-leakers: (See Appendix C for definition of "Re-Teaker")

This section includes all single- or double-shell tanks or catch tanks for which an off-normal or unusual occurrence report has been issued for assumed leaks or re-leaks. Tanks/catch tanks will remain on this list until either a) completion of Interim Stabilization, or b) the updated occurrence report indicates that the tank/catch tank is not an assumed leaker.

Tank 241-BX-111. This tank was declared an assumed re-leaker on April 30 , 1993. Pumping of the tank commenced on October 22, 1993. A total of 31,000 gallons was pumped by the end of November. The surface level measurement was 68.50 inches on November 30, 1993.

Resolution status: Upon completion of pumping, the surface level baseline for the tank will be adjusted. Tanks 241-BX-110 and 111 were. removed from the ferrocyanide Watch List on July 9, 1993, on the basis that the tanks contain $<1000 \mathrm{gm}$ moles of ferrocyanide.

Pumping stopped on October 29, 1993, when a leak in the 244-BX pit was detected, and resumed on November 5, after a faulty connection was repaired. Saltwel1 pumping from BX-111 is halted upon reaching maximum allowable level in 244-BX Double Contained Receiver Tank (DCRT). The contents of the DCRT are then transferred to $A N-101$, and pumping is resumed in BX-111. This wil1 be ongoing until pumping is completed for BX-111. A total of 31,000 gallons was pumped by the end of November 1993.

\section{B. Tanks with increases indicating possible intrusions:}

This section includes all single-shell tanks for which the surveillance data show that the surface level or ILL has met or exceeded the increase criteria, or are still being investigated.

Tank 241-8-202. A steady increase in the surface level measurement has been observed since December 1984. The manual tape pencil plummet is contacting liquid. When the quarterly reading was obtained on October 6, 1992, the level was recorded as 144.75 inches, thus exceeding the 2.00-inch increase criteria from the established baseline of 142.50 inches. The surface level measurement was rechecked on October 9, 1992, (145.50 inches) and October 13 (145.00 inches), verifying the increase and that the criteria had been exceeded. The surface level remained stable at 145.50 inches for November 1993. The monitoring frequency has been increased from quarterly to monthly. Occurrence Report RL-WHC-TANKFARM-1993-0024 was issued February 13, 1993. This tank is Sound, and Interim Stabilized/Intrusion Prevention completed. 
Resolution status: A photo package was initiated on May 11, 1993, to investigate the possibility of an intrusion. Review of previous photos was inconclusive. New photos are required to determine the actual supernatant increase, if any. A temporary baseline was established at 145.25 inches, until the new photos are available.

Tank 241-BX-101. On September 2, 1993, the surface level increased from 10.00 to 12.00 inches and has remained stable through November, fluctuating between 11.50 and 12.00 inches. In-tank photographs show the manual tape donut plummet contacting liquid in a shallow pool. This tank is an Assumed Leaker, and Interim Stabilized/Intrusion Prevention completed.

Resolution Status: Comparison of October 1986 photos with November 1988 photos shows evidence of an ongoing intrusion. A work package was initiated October 14, 1993, to obtain in-tank photographs which will be used to inspect the area under the plummet and investigate the possible intrusion. A sitewide in-tank photography program is being formed and photo schedules will be produced upon finalization. A finalized photo schedule is not complete, however, in-tank photos for this tank are tentatively scheduled for May 1994.

Tank 241-BX-103. This tank has shown an erratic increase in surface level measurements since January 6, 1986. On January 18, 1993, the surface level measurement in 103-BX exceeded the 0.50-inch increase criteria from the reference baseline of 19.50 inches, and was verified on January 20, 1993. Discrepancy Report S\&DA 93-522 was issued January 21, 1993. Occurrence Report RL-WHC-TANKFARM-1993-0036 was issued March 25, 1993. The surface level measurement has remained stable at 20.50 inches during the month of November. The FIC plummet is contacting liquid as indicated by in-tank photographs taken October 31, 1986. This tank is Sound, and Interim Stabilized/Intrusion Prevention completed.

Resolution status: The current level is greater than that prior to stabilization in November 1983. The tank was previous1y determined to have experienced an intrusion from 1977 to March 1983 (prior to stabilization). Subsequent isolation was expected to halt the intrusion, however, the intrusion is apparently ongoing. A work package was initiated on May 11 , 1993, to re-seal pits and risers and to obtain in-tank photos. The photos will be used to assess the current stabilization status of the tank. A visual survey of the area was performed to determine possible paths for precipitation to enter the tank. The weather covering on the pits and risers was found in place and undamaged. The existing grade is level and revealed no obvious draining problems. Ongoing design/isolation drawing review revealed that nozzles, floor drains and some transfer lines entering the heel pit have been left open. Photo verification of the intrusion will determine the need to provide additional isolation measures. A finalized photo schedule is not complete, however, in-tank photos for this tank are tentatively scheduled for May 1994.

Tank 241-BY-105. The LOW ILL has shown a slow increasing trend since 1986. Discrepancy Report S\&DA-93-561 was issued June 15, 1993. This tank showed what appeared to be an intrusion based on the old LOW analysis system, which assumed a constant baseline. Under the new LOH analysis system, however, the ILL is within acceptable tolerance (assuming a sloping baseline). The ILL is currently at 13.38 feet. The baseline is 13.392 feet. The monitoring frequency has been increased from quarterly to weekly. The manual tape 
surface level measurement does not show an increase. This tank is on the ferrocyanide Watch List, an Assumed Leaker, and not yet Interim Stabilized.

Resolution Status: The surface level and ILL are displaying behavior similar to TX-113 and TX-115. The ILL is showing an increase, while the surface level measurement is showing a decrease. This phenomena could be due to either solids dissolution or formation of a depression in the solids beneath the plummet in conjunction with an intrusion. Review of previous photos indicates the liquid volume is increasing, although it cannot be verified that the solids level is decreasing. A photo package was initiated to investigate the possibility of intrusion, or solids dissolution. A finalized photo schedule is not complete, however, in-tank photos for this tank are tentatively scheduled for May 1994.

Tank 241-5-103. The FIC was out of service from March 8 to May 14, 1993. The surface Tevel increased from 104.15 inches on March 8 to 104.80 inches after FIC repair on May 14, 1993. On August 20, 1993, a temporary basel ine of 104.80 inches was established. This tank has previously been on report for an increase but showed an erratic decreasing trend the latter part of November 1993. The readings ranged from 104.80 to 103.80 inches. The surface level measurement is currently at 104.00 inches. A request has been made for a reference elevation check. The LON, last scanned November 29, 1993, is within the .08 foot tolerance. This tank is Sound, and not yet Interim Stabilized.

Resolution status: After recalibration of the FIC on June 7, 1993, the surface level (SL) remained stable at approximately 104.65 inches. The SL shows a general increase since 1981. Review of tank level history has also shown the SL to show sudden increases following calibration. Recalibration has normally returned the SL to previous levels. Since the SL currently remains high after recalibration, it is possible that the SL has indeed reached the action criterion for this tank. A photo package for in-tank photos was initiated to investigate the possibility of an intrusion and will still be pursued. A finalized photo schedule is not complete, however, intank photos for this tank are tentatively scheduled for April 1994.

Tank 241-TX-111. The ILL has been showing a slow increase since 1989 based on the old LOH analysis system, which assumed a constant baseline. Under the new LOW analysis system, however, the ILL is within acceptable tolerance (assuming a sloping baseline). Discrepancy Report S\&DA 93-600 was issued September 8, 1993, when the ILL reached the 0.4-foot increase criteria from the reference baseline of 4.6 feet. The monitoring frequency has been increased from quarterly to weekly.

Resolution Status: The ILL trend was re-analyzed for this tank using the new "count rate" method. A steady, significant increase of 1.32 inch/year is evident. Surface level data is showing a decrease. Photos show a dry surface. The surface level decrease is expected to be caused by crumbling of the waste beneath the plummet. Overall, the waste level behavior of the tank is similar to that of $T X-113$ and 115 . A photo package was initiated on October 13, 1993, to investigate the possibility of an intrusion. A finalized photo schedule is not complete, however, in-tank photos for this tank are tentatively scheduled for March 1994.

Tank 241-TX-113. The LOW ILL has shown a slow increase since March 12, 1986, with both the neutron and gamma probes. The scan data on February 5, 1993, showed the ILL to be 5.5 foot and at the 0.4 -foot increase criteria from the 
reference baseline. S\&DA Discrepancy Report 93-534 was issued March 10, 1993. On September 3, 1993, the ILL exceeded the 0.4-foot increase criteria from the reference baseline of 5.1 feet. A revision to Discrepancy Report S\&DA 93-534 was issued September 9, 1993. This tank showed what appeared to be an intrusion based on the old LOW analysis system, which assumed a constant baseline. Under the new LOW analysis system, however, the ILL is within acceptable tolerance (assuming a sloping baseline). The ILL is currently at 5.26 feet $_{y} .001$ feet above the reference baseline of 5.259 feet. This tank is an Assumed Leaker, and Interim-Stabilized/Intrusion Prevention completed.

Resolution status: The technical evaluation of this tank was completed April 14, 1993. The results were inconclusive, with recommendation to accelerate the October 1997 waste characterization of the tank. This characterization is expected to confirm that solids are dissolving, causing an increase in ILL. Acceleration of waste characterization is not possible. Watch List tanks have first priority for core sampling. In-tank photos are expected to be available for review by February 1994. LOW scans are taken weekly, and surface level readings have been increased from a quarterly to a monthly frequency. A finalized photo schedule is not complete, however, intank photos for this tank are tentatively scheduled for March 1994.

Tank 241-TX-115. This tank has been on report since 1988 for what appeared to be an intrusion based on the old LOW analysis system, which assumed a constant baseline. Under the new LOW analysis system, however, the ILL is within acceptable tolerance (assuming a sloping baseline). Comparison of past and present in-tank photographs show no significant change in surface conditions or obvious evidence of intrusion. This tank is an Assumed Leaker, and Interim Stabilized/Intrusion Prevention completed.

Resolution status: The technical evaluation of the alert condition in this tank was completed April 14, 1993. The results were inconclusive, with recommendation to accelerate the October 1997 waste characterization. Waste characterization is expected to confirm that solids are dissolving, causing an increase in ILL. Acceleration of waste characterization is not possible for non-Watch List tanks. The 1981 photos show evidence of rain intrusion through a central pump pit riser. However, it cannot be concluded from the 1988 photos that the intrusion is ongoing. This tank will be included in the waste characterization with TX-113. LOW scans are taken weekly, and surface level readings have been increased from a quarterly to a monthly frequency. A finalized photo schedule is not complete, however, in-tank photos for this tank are tentatively scheduled for April 1994.

Tank 241-TY-102. On November 8, 1992, the automatic FIC surface level measurement of 32.10 inches exceeded the 0.50 -inch increase criteria from the reference baseline of 31.40 inches. Discrepancy Report S\&DA-92-489 was issued November 9, 1992. The tank has a history of intrusions and icicle-shaped mineral buildup on the FIC plummet. The FIC plummet is contacting a shallow pool of 1iquid. The surface level measurement was 31.70 inches for November 1993. The increase criteria of 0.50 inch, considered to be an extremely tight tolerance for this tank, was revised to 1.00 inch, which is more in line with other tanks that exhibit similar erratic surface level behavior. This tank is Sound, and Interim Stabilized/Intrusion Prevention completed.

Resolution status: This tank is experiencing an ongoing intrusion as is evident by comparison of November 1984 photos with July 1987 photos and an increasing trend in surface level data. A visual survey was conducted to 
determine possible paths for precipitation to enter the tank. The grade around the tank is level and weather covering is on the pits and intact. The photo package, initiated May 17, 1993, will be required to assess the current stabilization status of the tank, and to assist in determining the possible paths of intrusion. Ongoing design/isolation drawing review revealed that nozzles, floor drains and some transfer lines entering the pump pit have been left open. Photo verification of the intrusion will determine the need to provide additional isolation measures. A finalized photo schedule is not complete, however, in tank photos for this tank are tentatively scheduled for June 1994.

Tank 241-TY-106. Surface level readings were stable during 1990 through 1992 , ranging between 13.25 to 13.50 inches. The surface level readings fluctuated between 13.50 to 15.00 inches during 1993. In-tank photographs taken August 22, 1989, show the manual tape pencil plummet contacting a dry cracked surface with discarded tapes near the plummet. This tank is an Assumed Leaker, and Interim Stabilized/Intrusion Prevention completed.

Resolution status: Two readings reached 15.00 inches on October 2 and October 4, 1993, which constitute a sudden increase from 14.50 inches on August 1, 1993. On October 6, 1993, the readings returned to 14.25 inches. Similar behavior occurred on October 8,1987 , when the surface level jumped to the same level then returned to allowable limits. Photos taken August 22, 1989, show a number of discarded tapes beneath the plummet. Occasional anomalous readings would be expected because of the plummet touching the discarded tapes rather than the dry waste. The monitoring frequency has been increased from quarterly to monthly in order to determine a consistent trend.

241-E/N-151 Vent Station Catch Tank. The zip cord surface level reading exceeds the maximum operating limit of 36.00 inches. The manual tape has been out of service since July 7, 1992. A temporary zip cord was installed December 16, 1992. The level was 45.50 inches which exceeded the active tank limit of $50 \%$ volume of 40 inches ( 400 gallons). Transfers are not permitted until the tank is pumped and the level is within limits. Discrepancy Report S\&DA-92-511 was issued December 24, 1992. A new calibrated zip cord was installed May 26, 1993. The surface level reading is currentiy 69.00 inches.

Resolution status: Work packages are out to repair the manual tape and pump the catch tank. Extensive surface contamination in the surrounding area is hampering efforts to perform the needed activities. Sampling of the solution in the tank is necessary before pumping can begin. Because of the current stand down of work in tank farms, the resolution to pumping this vent station is on hold. Efforts to resolve this issue will resume as priority allows and transfers are required through this facility.

UX-302-A Catch Tank. The surface level measurement exceeds the maximum operating limit of 50.00 inches. Discrepancy report S\&DA-92-465 was issued May 12, 1992. The current surface level reading is 64.90 inches, which exceeds the $50 \%$ volume of 54 inches ( 8840 gallons). The FIC plummet is contacting liquid.

Resolution status: Work packages for the transfer of waste from UX-302-A and the repair of necessary instrumentation are being prepared, and the transfer of waste is being scheduled as a prestart item for the Cross Site Transfer. A work package has been prepared to sample/pump this catch tank. Because of the 
current stand down of work in tank farms, the resolution to pumping UX-302-A is on hold. Efforts to resolve this issue will resume as priority allows.

\section{SURVEILLANCE AND WASTE TANK STATUS HIGHLIGHTS}

\section{Tank 241-BX-111 Saltwell Jet Pumping}

Saltwel1 jet pumping began on October 22, 1993, to pump tank BX-111 into 244-BX Double Container Receiver Tank. Pumping continued until October 29, when a leak in the 244-BX pit was detected. Pumping was resumed on November 5 after a faulty connection was repaired. Saltwell pumping from BX-111 is halted upon reaching maximum allowable level in 244-BX Double Contained Receiver Tank (DCRT). The contents of the DCRT are then transferred to AN101 , and pumping is resumed in BX-111. This will be ongoing until pumping is completed for BX-111. A total of 31,000 gallons was pumped by the end of November 1993.

\section{Tank Waste Remediation System Safety Initiatives}

The U. S. Secretary of Energy has directed that six safety initiatives be implemented in the Tank Waste Remediation System Program to accelerate the mitigation/resolution of the higher priority waste tank safety issues at the Hanford Site. Forty two milestones were established for accomplishing the initiatives. In FY 1993 four milestones were completed on or ahead of schedule. One milestone was completed behind schedule. In November 1993, one milestone was completed (2a "Accept Interim Safety Basis by November 1993"). This brings the total for FY 1994 to two milestones completed on schedule.

\section{Tank Farms Stand Down (Administrative Hold)}

On August 12, 1993, non-essential work activities in the tank farms were put on administrative hold by WHC senior management, with only minimal essential activities to be conducted. Corrective actions were addressed in a Tank Waste Remediation System Tank Farm Resumption of Work Plan, dated September 13, 1993. Contained within the Work Plan is the Integrated Schedule for reinitiating individual work activities on an ongoing basis.

Testing of the SY-101 mixer pump continues to be successfully accomplished. Radioactive waste is being saltwell jet pumped from BX-111, with completion of the pumping scheduled for the end of January 1994. Many other tank farm work activities have now been fully resumed. In addition, reorganization is taking place to reduce management layers, and a new action plan for total upgrade is expected by February 1994.

\section{Tank 241-SY-101 Mixer Pump}

Test $\$ 16$ of Phase $B$ testing was completed on November 29. This test was six 30-minute runs at a motor speed of $750 \mathrm{rpm}$, at nozzle orientations of 35, $65,95,125$ and 185 degrees. This successfui test lasted the entire 3-hour run. Gas concentrations reached the following levels: 250 ppm hydrogen and $111 \mathrm{ppm}$ ammonia from a baseline of $31 \mathrm{ppm}$ and $58 \mathrm{ppm}$, respectively. This successful test will allow operations to proceed to test $\# 17$, scheduled to be performed on December 1, 1993. 
WHC-EP-0182-68

5. Tank Being Reviewed for Potential Addition to Watch List List.

Tank T-107 continues to be reviewed for inclusion on the Hydrogen Watch

\section{Criticality Safety Issues}

On April 30, 1992, an Unreviewed Safety Question (USQ) concerning criticality safety issues in the Tank Farms was declared to be a reportable event. Unusual occurrence report RL-WHC-TANKFARM-1992-0037 was issued. A prohibition was placed on all waste transfers into and between the tank farm facilities which is negatively affecting various Hanford programs. On September 1, 1992, the approved Justification For Cont inued Operations (JCO) was received. This establishes the 1 imitations for all tanks receiving transfers and also excludes any interim stabilization of single-she11 tanks until further evaluations are completed and approved by DOE-HQ. On December 15, 1992, the approved JCO was issued as WHC-SD-WM-JCO-001, "Justification for Continued Operations of Hanford High Level Waste Tanks Resulting From the Criticality USQ, 492-CRITSAS."

\section{Interim Safety Basis (ISB) for the Hanford High-Level Waste Storage Tanks}

Westinghouse Hanford Company (WHC) developed an integrated approach for Site compliance with DOE orders (5480.21, 5480.22, 5480.23). These orders required contractors to provide "a basis for interim operation and restrictions on interim operations" for existing facilities, and a plan for upgrading Safety Analysis Reports (SAR) and developing Tank Safety Reports (TSR). The MHC approach called for the preparation of "Interim Safety Basis" (ISB) documents to satisfy the first requirement while providing a basis for planning the SAR and TSR upgrades.

Among the first Hanford Site facilities for which this approach was implemented are the High Level Maste Storage Tanks of the Hanford Tank Farms. The Tank Farms ISB document provides a ready reference to the tank farms safety envelope. The safety envelope constitutes the technical basis for safe operation and maintenance of tank farm facilities, equipment, and processes. The ISB is intended to facilitate understanding of the safety envelope and its corresponding justification, until formalized SAR upgrades can be completed in accordance with requirements. This information is intended to be utilized for consideration of proposed changes, tests, or experiments to determine any potential adverse effects on the existing safety envelope. The ISB was approved by the Department of Energy for Implementation in November 1993.

\section{Review of Interstitial Liquid Level (ILL) Data Using New Analysis Method}

New ILL interpretation software was developed and went into effect October 1, 1993, for the purpose of re-evaluating ILL data using a new analysis method to determine the validity of the current classifications. A seven-year period was studied. The results of this review indicate that none of the 58 tanks reviewed were misclassified as a result of improper ILL interpretations. A11 tanks currently classified as "assumed leakers" remain the same. Those tanks classified as "sound" showed no data trends which would compromise that classification. 


\section{Occurrence Reports}

RL-WHC-TANKFARM-1993-0092 (OFF NORMAL) - INSTRUMENT CABLE SEVERED DURING SUBCONTRACTOR EXCAVATION RESULTS IN LOSS OF REMOTE ALARM SIGNALS FROM WEST TANK FARM FACILITIES (10-Day Report, 11/05/93)

On October 22, 1993, a subcontractor to Kaiser Engineers Hanford (KEH) was performing excavation work for piping installation when a Computer Automated Surveillance System (CASS) line was severed. The cable was severed by a backhoe while a trench was being dug for treated effluent transfer piping installation. This resulted in the 200 West Area tank farms being without remote alarm monitoring capabilities. Included in the cable severing was a 480 volt power line to the East-West vent station which had no impact to the facility. Electrical utility personnel were immediately dispatched to de-energize the power 1ine. The CASS contingency plan was initiated by operations personnel in accordance with the procedure.

Previous excavation work conducted by KEH was to identify all known utilities in the area where excavation was to be conducted. However, the CASS cable and power line were not identified. Engineering drawings were provided showing CASS lines but were inaccurate as to location.

A work package was initiated to repair the severed CASS cable. Repairs have been delayed pending MHC company procurement of repair material.

Contributing to this incident was the lack of supervision provided to the offsite personnel by Kaiser Engineers Hanford (KEH). There were no KEH personnel at the job site when the cable was severed. Kaiser line management had the responsibility to ensure that the subcontractor personnel were aware of all utilities, including the physical markers that identified the power lines.

The root cause to this incident were the inadequate administrative controls in place to ensure that all known utilities are identified on the civil engineering drawings being used at the job site. KEH personnel are performing another verification of all drawings to ensure the proper location of all underground utilities.

RL-WHC-TANKFARM-1993-0093 (OFF NORMAL) - ROLLOVER OF WASTE TANK 241-SY101 CAUSED MIXER PUMP TO SHUT DOWN DURING PHASE "B" ACCEPTANCE TESTING (10-Day Report. 11/09/93)

On October 25, 1993, rollover of double-shell waste tank 241-sY-101 occurred resuiting in the shutdown of the hydrogen mixer pump which was operating. The pump shutdown was caused by high vent header flow resulting from the rollover. The tank rollover occurred 11 minutes into a 20-minute pump run, as part of Phase "B" testing of the mixer pump Acceptance Test Procedure. The rollover was consistent with previous hydrogen releases of the tank. Hydrogen gas peaked at a concentration of 2144 parts per million (ppm) and ammonia at $423 \mathrm{ppm}$. the highest tank pressure obtained was -1.1" weight gravity (w.g.), and recorded temperature was $119.8{ }^{\circ} \mathrm{F}$ at thermocouple sensor $\$ 4$.

The decomposition of water and organic compounds appears to be the source of the flammable gas concentration below the surface of the waste 
in the tank. Prior to the mixer pump being installed on July 3, 1993, the trapped gasses would be released approximately every 100 days, which resulted in a temporary positive pressure in the tank.

The venting of waste tank SY-101 is occurring on a regular basis with mixer pump operations. The corrective actions taken are sufficient. No further corrective actions are necessary at this time.

On November 2, 1993, another rollover occurred during phase "B" mixer pump operations. This resulted in high vent header flow causing the shutdown of the mixer pump. The pump shutdown occurred 13 minutes into the 20-minute pump run. Hydrogen gas peaked at $1720 \mathrm{ppm}$ and ammonia peaked at $558 \mathrm{ppm}$.

The release of gasses, previously trapped, broke through the surface during pump operation, lowering the surface level and temperature of the tank. Test personnel expect further gas release events during and after mixer pump operations.

RL-WHC-TANKFARM-1993-0098 (OFF-NORMAL) - TANK FARM 241-SX SLUDGE COOLER EXHAUSTER EXCEEDS MAXIMUM VACUUM AS SPECIFIED IN OPERATING SPECIFICATIONS DOCUMENT (OSD-T-151-00013) (Not ification Report. $11 / 16 / 93)$

On November 16, 1993, it was discovered during roview of operating data sheets that Tank Farm 241-sX sludge cooler exhauster was operating with a vacuum below the required 11 init of Operating Specification Document (0SD-T-151-00013). The maximum required vacuum is to be $-5.9^{\prime \prime} \mathrm{W} . \mathrm{g}$. , and the exhauster was operating at $-6.2 " \mathrm{w} . \mathrm{g}$. Upon review of operating data sheets it was determined that the exhauster had been operating out of specification since the installment of a new motor on October 20, 1993. A work package was initiated to adjust air flow of the sludge cooler exhauster to reduce vacuum.

This incident had no adverse effects on the 241-SX sludge Cooler Exhauster System, the plant or the project.

RL-WHC-TANKFARM-1993-0103 (OFF-NORMAL) - TANK 101-AN OUT OF LIOUID LEVEL LIMITS WHEN NEY INTERIM OPERATIONAL SAFETY LIMITS PER WHC-SD-0SR-016 IMPLEMENTED ON NOVEMBER 30. 1993. AT 0001 HOURS (Notification Report. $11 / 30 / 93)$

On November 30, 1993, Waste Tank Operations implenented section 3.1.2 of the Interin Operation Safoty Requirements (IOSR) for Double-Shell Tanks (MHC-SD-0SR-0016, Rev. F). This section states the Limited Condition of Operation (LCO) Iimit for Primary Tank Liquid Level is $\leq 416$ inches. It was previously noted that the manual tape for this tank had been giving slack tape measurements above this limit and that an occurrence report would be required upon IOSR inplementation. The Food Instrument Corporation (FIC) level instrument is currentiy out of service. The slack tape reading on November 30 was 417.75 inches.

The LCO action statement was entered for Tank AW-101 level. All transfors into or out of this Watch List tank had proviousiy been 
suspended. Action was commenced to restore tank level to within the specified 1 imit of 416 inches (within 184 days as stated in the LCO). The work package to repair the FIC is being prepared for field work on a priority basis. When the FIC is repaired, the expected level reading should be approximately 410 inches. The steady increase in level by manual tape is consistent with crystalline growth on the tip of the plumet. After the FIC repairs are completed, a work package will be developed to remove the crystalline on the manual tape using a series of flushes. 
10. Waste Management External Advisory Committee Meeting Held November 19, 1993

The following excerpts on corrosion in the tank farms were presented at the Waste Management External Advisory Committee Meeting:

\section{Waste Tank Corrosion Issues}

- SST Corrosion

- DST Corrosion

- Transfer System Corrosion

- Current Corrosion Activities

\section{DST Corrosion Issues}

- Has SCC been adequately mitigated by stress-relief anneal and chemistry control?

- Is corrosion at the liquid/vapor interface (or any interface) a threat to DST integrity?

- Can we take lessons from SSTs and apply them to DSTs?

- New Tank Material Selection? 


\section{Single Shell Tank Corrosion Issues}

- Why do SSTs leak?

- When will the next SST leak and which one will it be?

- Can we reasonably expect to minimize future leaks either from non-stabilized SSTs or SST retrieval with inhibitor additions?

\section{SST Corrosion Statistics \& Correlation Studies}

Watch List Tanks

Waste Type

Farm

Construction Date

Capacity

Design
pH

Holding Time

Stabilized

Isolated

Steel

Contractor

Transfer System Corrosion Issues

- Is MIC a significant threat to Transfer Piping integrity?

- How should TWRS go about qualifying the existing Transfer Systems for continued service?

- Do we have adequate control of the transfer piping cathodic protection system? 


\section{Potential Corrosion Mechanisms in Hanford Waste Tanks}

- Stress Corrosion Cracking

- Pitting

- Crevice Corrosion

- Uniform Corrosion

- Microbiologically-Induced Corrosion

- Hydrogen Embrittlement

- Corrosion of Concrete Reinforcing Steel

\begin{tabular}{|c|c|c|}
\hline \multicolumn{3}{|c|}{ DST Corrosion Specifications for Control of SCC } \\
\hline & Variable & Specification Limit \\
\hline For N03- $<1.0 \mathrm{M}$ & $\begin{array}{l}\mathrm{OH}- \\
\mathrm{NO} 2-\end{array}$ & $\begin{array}{l}0.010 \mathrm{M}<\mathrm{OH}-<5.0 \mathrm{M} \\
0.011 \mathrm{M}<\mathrm{NO2}-<5.5 \mathrm{M}\end{array}$ \\
\hline For $1.0 \mathrm{M}<\mathrm{N03}-<3.0 \mathrm{M}$ & $\begin{array}{l}\mathrm{OH}- \\
\mathrm{OH}-\end{array}$ & $\begin{array}{l}0.1^{\circ}(\mathrm{NO} 3 \text { concentration }) \\
<0 \mathrm{OH}<10 \mathrm{M} \\
>0.424^{\circ}(\mathrm{NO3} \text { concentration) }\end{array}$ \\
\hline For N03- > 3.0M & $\begin{array}{l}\mathrm{OH}- \\
\mathrm{OH}-+\mathrm{NO} 2- \\
\mathrm{NO3-}\end{array}$ & $\begin{array}{l}0.3 \mathrm{M}<\mathrm{OH} \cdot<10 \mathrm{M} \\
>1.2 \mathrm{M} \\
<5.5 \mathrm{M}\end{array}$ \\
\hline
\end{tabular}

- Only valid for Nitrate Based Wastes (PUREX) at temperatures less than $100^{\circ} \mathrm{C}$.

- Non-representative (single point) samples. 
Cursory Analysis of Non-interim Stabilized Liquid Sample Data

- Only 13 of the 45 SSTs evaluated contain PUREX based waste

- Results:

\begin{tabular}{|c|c|c|}
\cline { 2 - 3 } \multicolumn{1}{c|}{} & \multicolumn{2}{c|}{$\begin{array}{c}\text { MEET DST } \\
\text { SPECS }\end{array}$} \\
\cline { 2 - 3 } \multicolumn{1}{c|}{} & YES & NO \\
\hline LEAKER & $5 / 13$ & $5 / 13$ \\
\hline SOUND & $3 / 13$ & $0 / 13$ \\
\hline
\end{tabular}

11. Changes to the Report

Appendix A. Haste Tanks Surveillance Monitoring Tables

Table A-4. Single-Shell Tanks Containing Concentrations of Organic Salts - additional organic salt concentration information for these tanks has been added to this table. 
WHC-EP-0182-68

This page intentionally left blank 
WHC-EP-0182-68

APPENDIX A

WASTE TANK SURVEILLANCE MONITORING TABLES

A-1 
WHC-EP-0182-68

This page intentionally left blank 
TABLE A-1. WATCH LIST TANKS (Sheet 1 of 2)

These tanks have been identified as Watch List Tanks in accordance with Public Law 101-510, Section 3137, " Safety Measures for Waste Tanks at Hanford Nuclear Reservation," (1990). These tanks have been identified as the Priority 1 Hanford Site Tank Farm Safety Issues: "Issues/situations that contain most necessary conditions that could lead to worker (onsite) or offsite radiation exposure through an uncontrolled release of fission products, e.9., Tank SY-101."

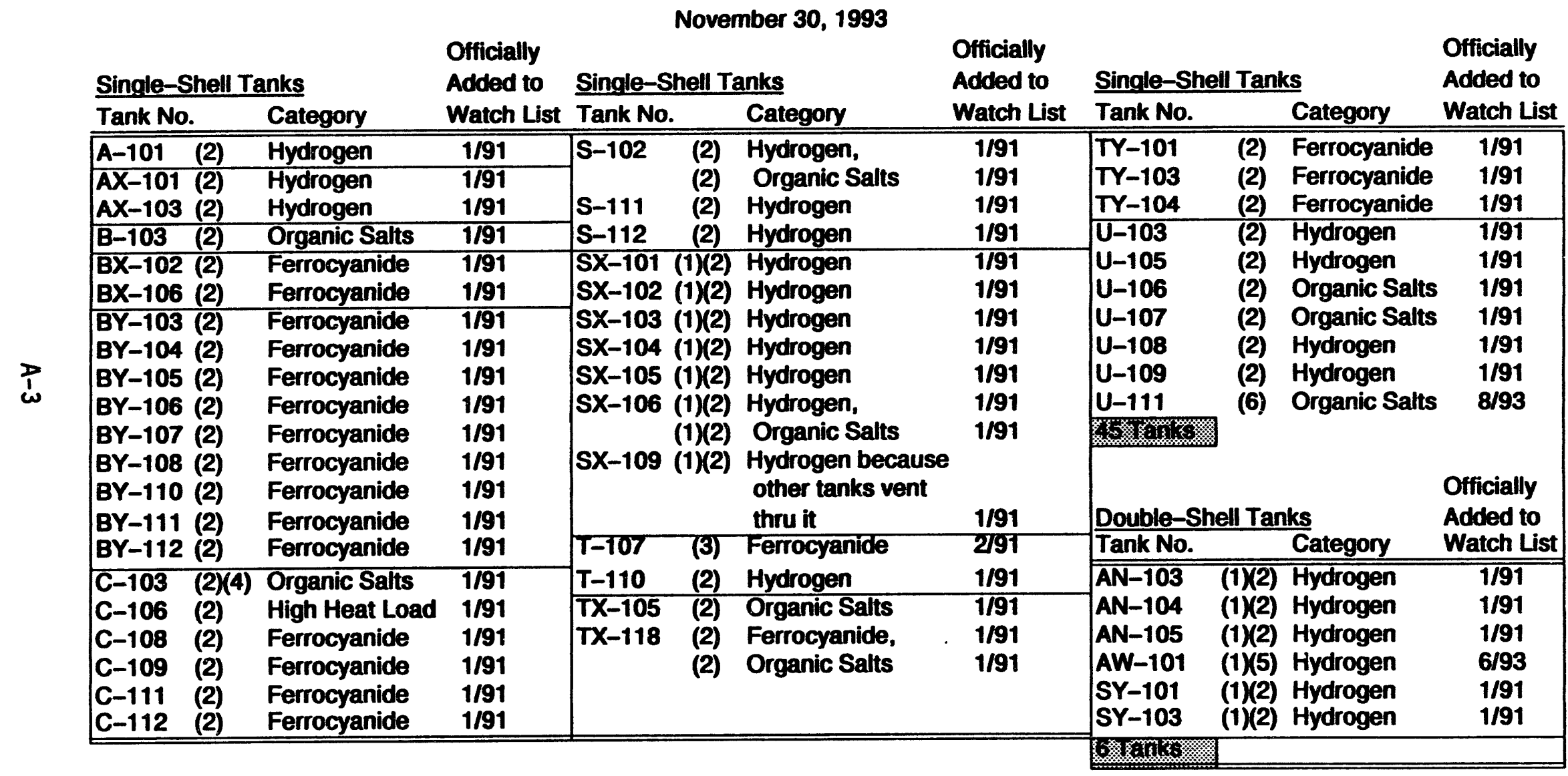

See footnotes next page 


\section{TABLE A-1 WATCH LIST TANKS (Sheet 2 of 2)}

Footnotes:

(1) These eight single-shell tanks and the six double-shell tanks on the Watch List are actively ventilated.

Although on various dates beginning in March 1990, WHC identified tanks containing ferrocyanide, organic salts, etc., which were then added to this report as Watch List tanks, the following official notifications were made to DOE-RL:

(2) Letter 9059124, H. D. Harmon, WHC, to R. E. Gerton, DOE-RL, "Safety Measures for Waste Tanks at Hanford Site, Richland, Washington," dated January 8, 1991, identified 23 ferrocyanide tanks, 23 tanks with potential for accumulation of flammable gas, eight organic tanks, and one high heat load tank, as being Watch List tanks. (52 tanks)

The ferrocyanide and hydrogen tanks were declared Unresolved Safety Questions (USQ); the organic tanks and the high heat load tank were within the safety envelope as defined by the safety analysis reports and were not designated as USQs.

(3) Letter 9059124.1 (revision to 9059124 above), dated February 8, 1991, added T-107 to the Ferrocyanide Watch List. (53 tanks)

(4) Tank C-103 was declared a USQ per Unusual Occurrence Report RL-WHC-TANKFARM-1992-0069, issued September 1992, because of an organic layer covering the surface. This tank was previously identified as a Watch List tank in footnote (2) above.

(5) Letter 9354700, J. C. Fulton, WHC, to R. E. Gerton, DOE-RL, "Addition of Tank 241-AW-101 to Flammable Gas Watch List," dated June 3, 1993, added this double-shell tank to the Watch List. (54 tanks)

(6) Letter 9353957, J. C. Fulton, WHC, to R. E. Gerton, DOE-RL, "Single-Shell Waste Tank 241-U-111," dated May 24, 1993, recommended this tank be included on the Organic Tanks Watch List. This tank was added to the Watch List on August $31,1993$.

Notes: BX-110, BX-111, BY-101 and T-101 were removed from the Ferrocyanide Watch List in July 1993, per letter 93-CAB-223, John H. Anttonen, DOE-RL, to T. M. Anderson, WHC, "Resolution of Unreviewed Safety Question for Four Ferrocyanide Tanks," dated July 9, 1993. 
TABLE A-2. TANKS CONTAINING >1000 GRAM MOLE OF FERROCYANIDE (Watch List Tanks) (Sheet 1 of 2)

These tanks have been declared an Unreviewed Safety Question (USO) because their explosion potential exceeds previousty reported safety analysis consequences (1).

Temperatures in these tanks did not exceed the maximum temperature criteria or surveillance frequency limits for November 1993.

All Watch List tanks are reviewed for increasing temperature trends. Tanks connected to TMACS are required to be monitored continuously: those not connected are required to be monitored weekb. Temperatures are taken in the waste unless indicated otherwise.

\begin{tabular}{|c|c|c|c|c|c|c|c|c|c|c|}
\hline Tank No. & & $\begin{array}{c}\text { Highest } \\
\text { Temperature } \\
\text { Reading } \\
\text { in Waste (F.) }\end{array}$ & $\begin{array}{c}\text { Date } \\
\text { of } \\
\text { Reading }\end{array}$ & $\begin{array}{l}\text { Readings } \\
\text { Taken by } \\
\text { TMACS (5) }\end{array}$ & $\begin{array}{c}\text { Total } \\
\text { Waste } \\
\text { (inches) (6) }\end{array}$ & $\frac{\text { FeCN (2) }}{(\times 1000 \mathrm{~g} \mathrm{~mol})}$ & $\frac{\text { Estimated }}{\text { (Btu/h) }}$ & $\frac{\text { Heat Load (3) }}{(\mathrm{kW})}$ & $\begin{array}{c}\text { Date } \\
\text { Declared } \\
\text { Assumed } \\
\text { Leaker } \\
\end{array}$ & $\begin{array}{c}\text { Interim } \\
\text { Stabilized } \\
\text { Date }\end{array}$ \\
\hline (5) & & x ck & 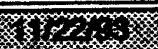 & xy & 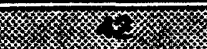 & x & x & 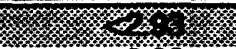 & $x^{x} \times x$ & 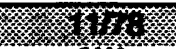 \\
\hline$B x-106$ & & 70 & $11 / 2253$ & No & 24 & $<1$ & $<10000$ & 293 & Sound & Wh \\
\hline$j^{2}\{g$ & & 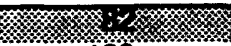 & 柫 & sax & $\operatorname{los}_{3}$ & in & 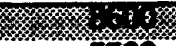 & 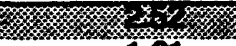 & 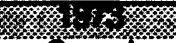 & 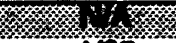 \\
\hline BY-104 & Alser 1 & 128 & $11 / 29 / 93$ & Yes & 155 & 83 & 5500 & 1.61 & Sound & $1 / 5$ \\
\hline $3 \%$ & (1) & 级 & $y$ & \% & 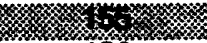 & 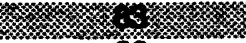 & 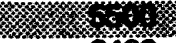 & 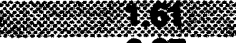 & 2 & 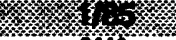 \\
\hline BY-10 & Riser 10C & 113 & $1101 / 93$ & Yes & 190 & 36 & 3100 & 0.97 & 1904 & Wh \\
\hline F & \% & 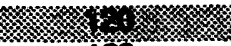 & s & 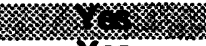 & 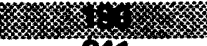 & & 8 & 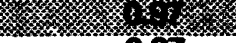 & & \\
\hline BY-106 & & 12 & $11 / 2893$ & Yes & 241 & 70 & 3500 & 0.97 & 1584 & $H h$ \\
\hline$F$ & & 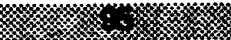 & s. & $x_{0}$ & $y^{2}$ & 2 & 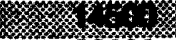 & rys & & zos \\
\hline BY -108 & & 110 & $11 / 00 / 93$ & Yes & 90 & 56 & 25000 & 674 & 1972 & $2 / 5$ \\
\hline s cos & $x \quad x$ & $x$ & 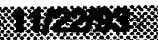 & s. & 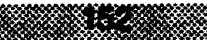 & 纱 & & 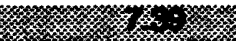 & & Mn \\
\hline BY -110 & Riser 10 A & 109 & 11122293 & Yes & 152 & 71 & 25200 & 7.39 & Sound & $1 / 25$ \\
\hline ; & $8 \sigma^{\prime}$ & 紧; & 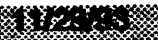 & 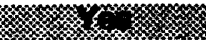 & 经 & 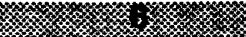 & -4 & $\alpha 2$ & 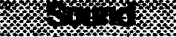 & 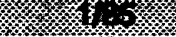 \\
\hline$B Y-111$ & Piser 14 & 84 & $11 / 2993$ & Yes & 174 & 6 & 34200 & 10.02 & Sound & $1 / 185$ \\
\hline 素\% & 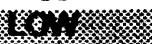 & $x$ & 悉 & K & 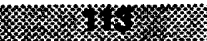 & 玹 & mis & $x$ & 10 & 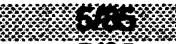 \\
\hline BY-112 & Piser 5 & 90 & $11 / 2993$ & Yes & 113 & 2 & $<10000$ & 293 & Sound & $5 \% 5$ \\
\hline soxis & 4 & s & 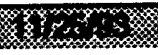 & 玹 & 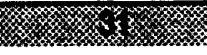 & 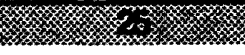 & (1) & 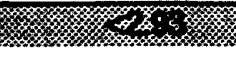 & ints & 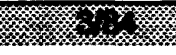 \\
\hline C-108 & Piser 1 & 85 & 11/2ass & No & 31 & 25 & 10000 & $<2.93$ & Sound & $3 / 84$ \\
\hline son & - & $=7$ & $4 y_{1}=2$ & 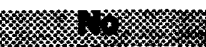 & 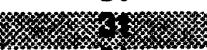 & $x \cdot$ & $x$ & 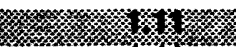 & & 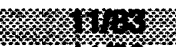 \\
\hline C-109 & Hiser 3 & 79 & $11 / 125$ & No & 31 & 20 & 300 & 1.11 & sound & $11 / 63$ \\
\hline sox & & 柇 & 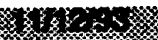 & 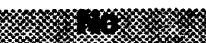 & & $x^{2}$ & 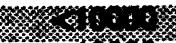 & 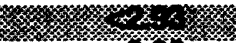 & & 筮 \\
\hline C-112 & Rser 1 & 84 & $17 / 25 / 93$ & No & 25 & 31 & $<1000$ & 2.93 & sound & 90 \\
\hline 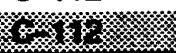 & . & $x$ & 135 & 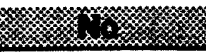 & 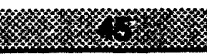 & s.t. & 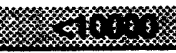 & 然 & 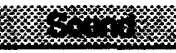 & 管 \\
\hline$T-107$ & & 69 & $11 / 17 / 93$ & No & 73 & 5 & $<10000$ & 293 & 1984 & MA \\
\hline 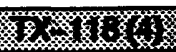 & & 然 & 禁 & 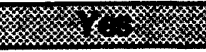 & 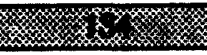 & x & ints & x & 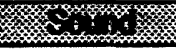 & $\quad+$ \\
\hline TY-101 & & 70 & $11 / 2293$ & Yes & 50 & 23 & $<10000$ & 293 & 1973 & $8 / 83$ \\
\hline 桨1) & & 缃 & xhoris & 聯 & $x$ & $x$ & sos & 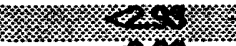 & $x+3 x$ & 繁; \\
\hline$T Y-104$ & & 70 & $11 / 15 / 93$ & Yes & 24 & 12 & $<1000$ & 293 & 1901 & $1 / 03$ \\
\hline to & & & $\gamma_{1}$ & $\bar{K}^{\mathrm{g}}$ & $\mathrm{S}_{\mathrm{S}}$ & $\operatorname{loc}^{\prime}$ & & & & \\
\hline
\end{tabular}

Note: Tanks BX-110, BX-111, BY-101 and T-101 were removed from this Watch List in July 1993, per letter 93-CAB-223, John H. Anttonen, DOE-AL, to T. M. Anderson, WHC, "Resolution of Unreviewed Safety Question for Four Ferrocyanide Tanks," dated July 9, 1993.

FOOTNOTES: See next page 
TABLE A-2. TANKS CONTAINING >1000 GRAM MOLE OF FERROCYANIDE (Watch List Tanks) (Sheet 2 of 2)

\section{FOOTNOTES:}

(1) This Priority 1 Waste Tank Safety Issue is stated as follows: "Could the concentrations and distribution of ferrocyanide and nitrate/nitrite in the tanks lead to an explosion if allowed to heat up or if an uncontrolled exothermic reaction could occur?"

(2) The amount of FeCN reported in the tanks is based on WHC-SD-WM-ER-133-REV 0, An Assessment of the Inventories of the FeCN Watch List Tanks," (Table 3-7), October 1991.

(3) The estimated heat generation rates are from WHC-EP-0474-4, "Quarterly Report on Defense Nuclear Facilities Safety Board Recommendation 90-7 for the Period Ending March 31, 1992," Table 1-A, dated January 1992. Tank 104-BY oniy estimated per WHC-EP-0521, "SST 104-BY Thermal Hydraulic Analysis," October 1991 (kW = $3412 \mathrm{Btu} / \mathrm{h})$. A new thermal hydraulic analysis of several tanks is currently being updated and is expected to be processed for external release by the end of FY1993. This document analyzes six tanks, BY-105, 106, 108, 110, and 111, and C-109. Information from this document will be incorporated in future monthly reports as soon as the clearance process is completed.

(4) This tank also contains a high concentration (>3\% wt TOC) of organic salts.

(5) This column indicates which tanks are being monitored by the Tank Monitor \& Control System (TMACS); automatic temperature readings are taken continuousty. Temperatures in tanks connected to TMACS but temporarily not being monitored by TMACS are taken manually.

(6) Total waste in Kgal taken from Table E-5, Inventory and Status by Tanks for SSTs. Kgalinches calculations for the temperature tables are as follows: (waste in inches is an approximation only for these temperature tables)

\section{Kgal waste -12.5 vall waste* +12 inches* $2.75 \mathrm{Kgal} / \mathrm{inch}$}

- The bottom 12 inches in dish bottom tanks contain $12.5 \mathrm{Kgal}$. All tanks are calculated as dish bottom tanks for the temperature tables, although $\mathrm{A}$ and $\mathrm{AX}$ farms have flat bottoms. Inches are from centerline tank bottom. 


\section{TABLE A-3. TANKS WITH POTENTLLL FOR HYDROGEN OR FLAMMABLE GAS ACCUMULATION}

ABOVE THE FLAMMABILITY LMMT (Wakch List Tanks)

These tanks have an Unreviewed Safety Cuestion (USO) because of the potential consequences of a radilogical release resulting from a from a fiammable gas burn, an event not analyzed in the SST Safoty Analysis Report.

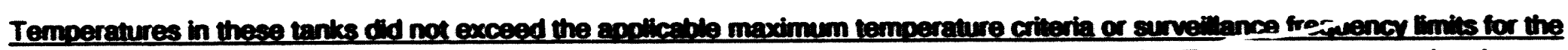

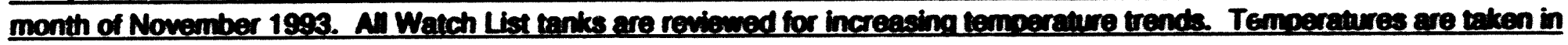
the wasto unless indicated otherwise.

\begin{tabular}{|c|c|c|c|c|c|c|}
\hline Tank No. & $\begin{array}{c}\text { Highest } \\
\text { Temperature } \\
\text { Reading (F.) } \\
\text { in Waste }\end{array}$ & $\begin{array}{c}\text { Date } \\
\text { of } \\
\text { Reading }\end{array}$ & $\begin{array}{c}\text { Totel } \\
\text { Waste (3) } \\
\text { (inches) } \\
\end{array}$ & $\begin{array}{l}\text { Monitoring } \\
\text { Frequency }\end{array}$ & $\begin{array}{c}\text { Assumed } \\
\text { Leaked } \\
\text { Date } \\
\end{array}$ & $\begin{array}{c}\text { Interim } \\
\text { Stabilized } \\
\text { Date }\end{array}$ \\
\hline$A-101$ & 154 & 11/2ass & 554 & Woeldy & sound & $\mathrm{ma}$ \\
\hline$x-103$ & 116 & 11 2 s s & & toon & sorid & \\
\hline s-111 & 82 & $11 / 2, s$ & 24 & Hody & & \\
\hline $5 x-101(5)$ & 152 & $11 / 17 / 3$ & 173 & Wooldy & sotin & \\
\hline $5 x-100$ & & $11 / 2=3$ & 26 & wody & & \\
\hline $5 x-105$ & & 1172.5 & & & & \\
\hline $5 x-100(1)$ & & $11 / 2, x_{0}$ & & & & \\
\hline$T-110$ & 5 & $11 / 0593$ & 145 & Weoudy & solno & $\mathbf{m a}$ \\
\hline U-105 & & $11 / 203$ & & & & \\
\hline $0-109$ & 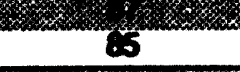 & $11 / 203$ & 176 & Woenty & sot & an \\
\hline$x-104$ & 118 & $11 / 2.53$ & & Weenty & SOUND & \\
\hline 1W-101 (4) & 100 & $11 / 50=3$ & & woody & soum & \\
\hline Sr-101 & 130 & $11 / 20 \mathrm{si3}$ & & & soun & \\
\hline $8 x$ & & 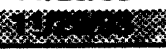 & & & 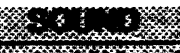 & \\
\hline
\end{tabular}

(1) Tank SX-109 has the potential for flammable gas accumulation onty because other SX tanks vent through ih.

(2) Tanks S-102 and SX-106 atso contain potentialy high concentrations of organic salts.

(3) See lootnote (6) in Tablo A-2 (Ferrocyenide Tanks) for Total Wastennches calculations. Weste in inches is an approdination lor temperature tebles onty.

(4) Tank 241-AW-101 was added to thits list per letter 9354700, J. C. Fulton, WHC, To R. E Genton, DOE-Fl. - Addition of Tank 241-AW-101 to Flammabilo Gas Watch List," dated June 3, 1993.

(5) Tank SX-101 is at the sumellince alent of 10 degrees over baseline. Onty 2 thermocouples out of 6 are operating. Dexta is inconsistent and suspect. Discrepancy Pleport written; being investigated. 
TABLE A-4. SINGLE-SHEL TANKS CONTANMG CONCENTRATIONS OF ORGANIC SALTS $>3$ WEIGHT \% TOTAL ORGANIC CARBON (TOC) (Waich List Tanks) (Sheet 1 of 2 )

These tanks have organic chemicals which are potentiathy flammable and mbetures of organic materiats mbxed with nilrete and nitrate salts can deilagrate. They are listed here because of their "potential for release of hich level weste because of uncontrolled increases in the temperature or preseure" Double-Shell tentis have $>3$ Weight $\%$ TOC and are not on the Watch List because they contain moethy liquid and there is no credible organic salety concem lor taniss which contain mosthy lipuid. The salety concern is with tanks that primarly contain solids because they could dry out and heat up, and ohiph organic concentrations in the tanks could support an exothermic reaction at elevated temperatures (350 decrees F/180 degrees C)." These tanks (with the euception of C-10S). do not have an associated USO because the presence of organic material was reviewed in the SST Safety Analyals Pleport.

Temperatures in these tanks of not exceed the acolicable maximum lemperature criteria or anvellance frecuency linits for the month of

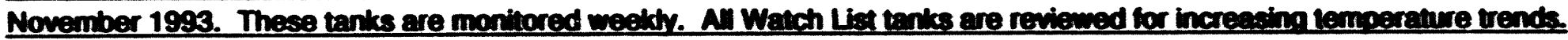

Temperatures are taken in the waste unless indicated othenwise.

\begin{tabular}{|c|c|c|c|c|c|c|c|c|c|c|c|}
\hline Tank No. & $\begin{array}{l}\text { Temperature } \\
\text { Reading (F.) } \\
\text { in waste }\end{array}$ & $\begin{array}{l}\text { Date } \\
\text { of } \\
\text { Reading }\end{array}$ & $\begin{array}{l}\text { Total } \\
\text { Wede } \\
\text { inches (4) }\end{array}$ & $\begin{array}{l}\text { Aseumed } \\
\text { Leaked } \\
\text { Dete }\end{array}$ & $\begin{array}{l}\text { Interim } \\
\text { Stabllized } \\
\text { Date }\end{array}$ & Source of Waste (11) & $\begin{array}{l}\text { Oreanic } \\
\text { Content } \\
(\text { mes })(6)\end{array}$ & $\begin{array}{c}\text { and } \\
\text { Nano } 2 \\
(\operatorname{mes} \times 10)\end{array}$ & $\begin{array}{c}\text { Toc } \\
\text { (N.\%) } \\
(\pi)\end{array}$ & $\begin{array}{l}\text { Waste Surtace } \\
\text { Potenitally } \\
\text { Dy (8) }\end{array}$ & $\begin{array}{l}\text { Last } \\
\text { Date } \\
\text { Sompled }\end{array}$ \\
\hline B-103 & 68 & $11 / 1293$ & 29 & 1978 & 2005 & $\begin{array}{l}\text { First and second cycle waste from } \\
\text { B Plant and in-tank sollifilication } \\
\text { (TTS-1 \& mS-2) eveporator bottoms }\end{array}$ & $11.4(9)$ & $60.5(9)$ & 3.3 & $\bar{x}$ & $9 / 75$ \\
\hline C-103(3) & 122 & $11 / 2293$ & 78 & sound & MA & $\begin{array}{l}\text { PUPEX and lnsoluble strontium- } \\
\text { rich shicing solids from the } \\
\text { operation of } 244-C A \text { Vaul }\end{array}$ & - & - & - & - & 990 \\
\hline$S-102(1)$ & 108 & 11 rass & 207 & Sound & wA & PEDOX & $21.0(10)$ & $41.0(10)$ & 6.1 & $x$ & $2 / 80$ \\
\hline $5 x-106(1)$ & 112 & $11 / 2993$ & 2003 & sotin & $\mathbf{m a}$ & $\begin{array}{l}\text { Salt waste and first Cycle } \\
\text { condensate trom PEDOX, and } \\
\text { 242-S Evaporator bottoms }\end{array}$ & $14.6(9)$ & $80.9(9)$ & 4.3 & & $8 / 79$ \\
\hline$T X-105$ & 102 & $11 / 17 / 93$ & 228 & 1977 & $\mathbf{S P 3}$ & ) Tributyl phosphate (TBP) & $12.8(9)$ & $52.7(9)$ & 3.7 & $x$ & $1 / 81$ \\
\hline$T x-118(2)$ & 77 & $11 / 2283$ & 134 & sound & 403 & ) process weste and 242-T & $20.2(10)$ & $50.4(10)$ & 5.9 & $x$ & 9/81 \\
\hline $\mathrm{U}-106$ & 82 & $11 / 2993$ & 90 & solin & $M A$ & Jvaporator bottoms & $46.6(10)$ & $52.4(10)$ & 13.6 & & 677 \\
\hline$U-107$ & 78 & $11 / 2993$ & 155 & sound & $\mathrm{MA}$ & 1 & $14.7(9)$ & $75.4(9)$ & 4.3 & & 1274 \\
\hline$U-111(5)$ & 80 & $11 / 2993$ & 127 & Sound & ma & Concentrated 8 Plant Wasto & $48.2(10)$ & $---(10)$ & 14.1 & $x$ & $7 / 93$ \\
\hline 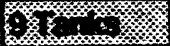 & & & & & & & & & & & \\
\hline
\end{tabular}

See Footnotes ned page 


\section{TABLE A-4. SWMEL-SHELL TANKS CONTANMG CONCENTRATIONS OF ORGANIC SALTS $>3$ WEIGHT \% TOTAL ORGANIC CARBON (TOC) (Sheet 2 of 2 )}

Footnotes:

(1) These tenks also have the potendal for hydrocen or franmable gess accumutatien.

(2) Tank TX-118 also contains lerrocyenida

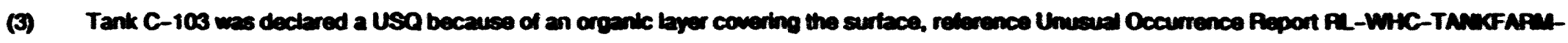
1992-0009, beved September 1992

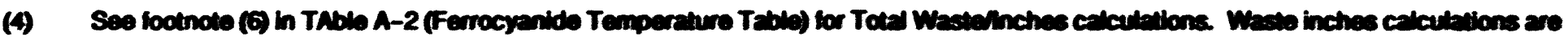
approdimations only for tomperature tables.

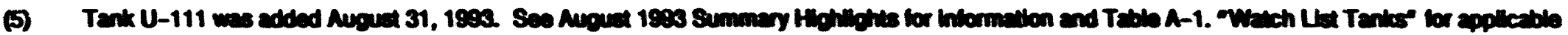
reference.

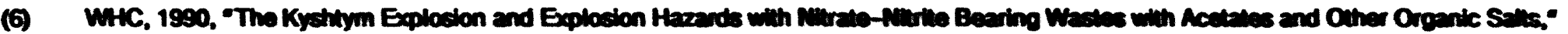
WHC-SD-LB-033, Westinghouse Hantord Company, Fichiand, Weshington

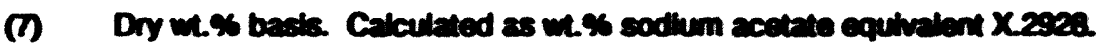

(8) Due to absence of apematant liquid.

(9) Calculated from data devaloped by Track Radibective Components (IRAC) computer code, 1924.

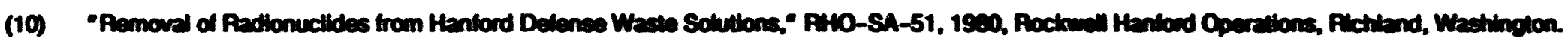
All or part of liquid from which composition data were deatued may have been transierred to doutbla-shell tarles.

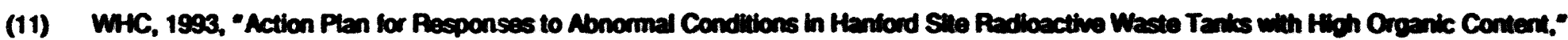
WHC-EP-0461, Rov. 1. Westinghouse Hantord, Pichland, Westingtor. 
TABLE A-5. SWGLE-SHELL TANKS WITH HIGH HEAT LOADS $(\mathbf{4 0 , 0 0 0}$ Bumy)yshed 1 of 2)

High heat load tanks have temperature surveillance requirements established by SD-WM-SAR-006 REV 1. "SST tsolation Salety Anabjis Repont" dated

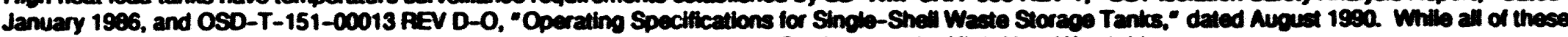
tanks are considered high heat loed tanks per SAR definition, onty one (241-C-109) is on the flloh Heet Walch List.

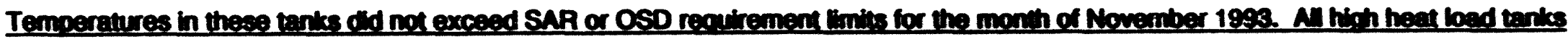

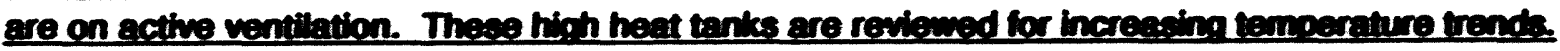

Temperatures are taken in the waste unloss indicated othencias.

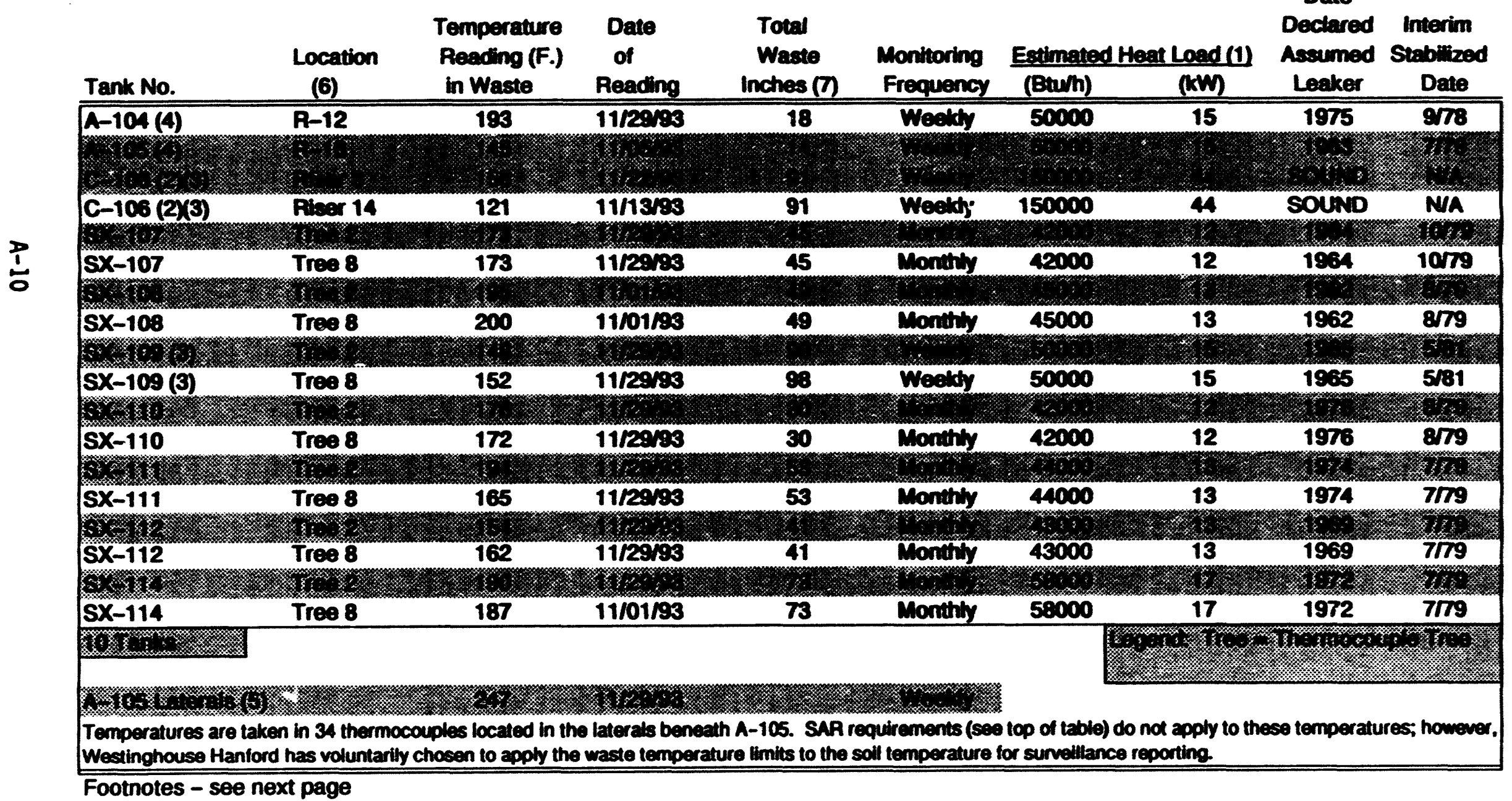

Footnotes - see next page 


\section{TABLE A-5. SINGLE-SHEL TANKS WITH HIGH HEAT LOADS $(\$ 40,000$ Btu/h)(Sheet 2 of 2)}

\section{Footnotes:}

(1) High heat loads as of 1988, evaluation completed April 20, 1989 (kW = 3412 Btum). The predominant heat load for these tanks is from CS 137 (half life of 30 years) and SR 90 (hall life of 28.1 years). Tank C-105 was re-evaluated in WHC-SO-WM-ER-178. "Thermal Analyels of Tank 241-C-105 in Support of Process Test," January 1993. Engineering Change Notice 1196834 , June 24, 1993, changed the status of C-105 from High Heat Load to Normad, effecthe Juhy 1, 1993.

(2) Periodic water additions are required in C-106 to maintain evaporative cooling and thus prevent overheating. This tank is scheduled for partial retrieval starting in 1997, at which time cooling water additions will be discontinued.

(3) Watch List Tanks: C-106 is on the Watch List because "without water additions (in the event of a leak) the tank could exceed structural temperature limits resulting in unacceptable structural damage." SX-109 is on the hydropen Watch List because it has the potential for flammable gas accumulation due to other SX tanks venting through it.

(4) A-104/105/106 exhauster has been out of service from October 1, 1991, untll August 20, 1992, when lt was briefly restarted. Problems exist which must be resolved before the exhauster is operational. Temperatures in A-104 and A-105 are monltored weekdy.

(5) Maximum lateral temperatures under A-105 increased 20 degrees F. by January 1992, but then dropped a few degrees and have remained fairly stable at current temperature. These temperatures are monitored weekly.

(6) Tanks A-104 and A-105

Two temperature probes are installed in risers in A-104, and six are installed in risers in A-105. These are individual probes. In A-104, the probes are in contact with the studge; in A-105, they are in contact with the bottom of the tank (A-105 has a bulged bottom).

Tank C-106

Tank C-106 has six functioning thermocouples ("1 through 6 ) on riser 8, and 12 functioning thermocouples on riser 14.

Tanks SX-107, 108, 109, 110, 111, 112, and 114

Each of these tanks has eight thermocouple trees, with elght thermocouples on each tree, with the exception of SX-108, which has four operational thermomocouples on each of two trees. Tree $\$ 2$ and Tree $\$ 8$ are monitored in each of these SX tanks.

(n) Calculations for Total Waste Inches: see footnote (6). Table A-2 (Ferrocyanide Tanks). Waste in inches is an approximation only for temperature tables.

(8) There are 19 single-shell tanks with active ventllation (elght are on the Watch List as Indicated by an asterisk):

$\begin{array}{lll}A-104 & S X-101: & S X-107 \\ A-105 & S X-102: & S X-108 \\ A-106 & S X-103: & S X-109 \\ C-104 & S X-104: & S X-110 \\ C-105 & S X-105: & S X-111 \\ C-106 & S X-106 & S X-112 \\ & & S X-114\end{array}$




\section{TABLE A-6. NON-WATCH LIST LOW HEAT LOAD TANKS $(<40,000 \mathrm{Btu} / \mathrm{h})$ \\ (Page 1 of 3)}

Temperatures are taken semiannually in January and July, unless otherwise indicated, in the following 96 single-shell tanks. Legend follows table.

\section{Highest Temperatures}

taken in waste Total Waste (1)

Tank No. Jan. 93 Jul. 93 Kagl Inches Comments

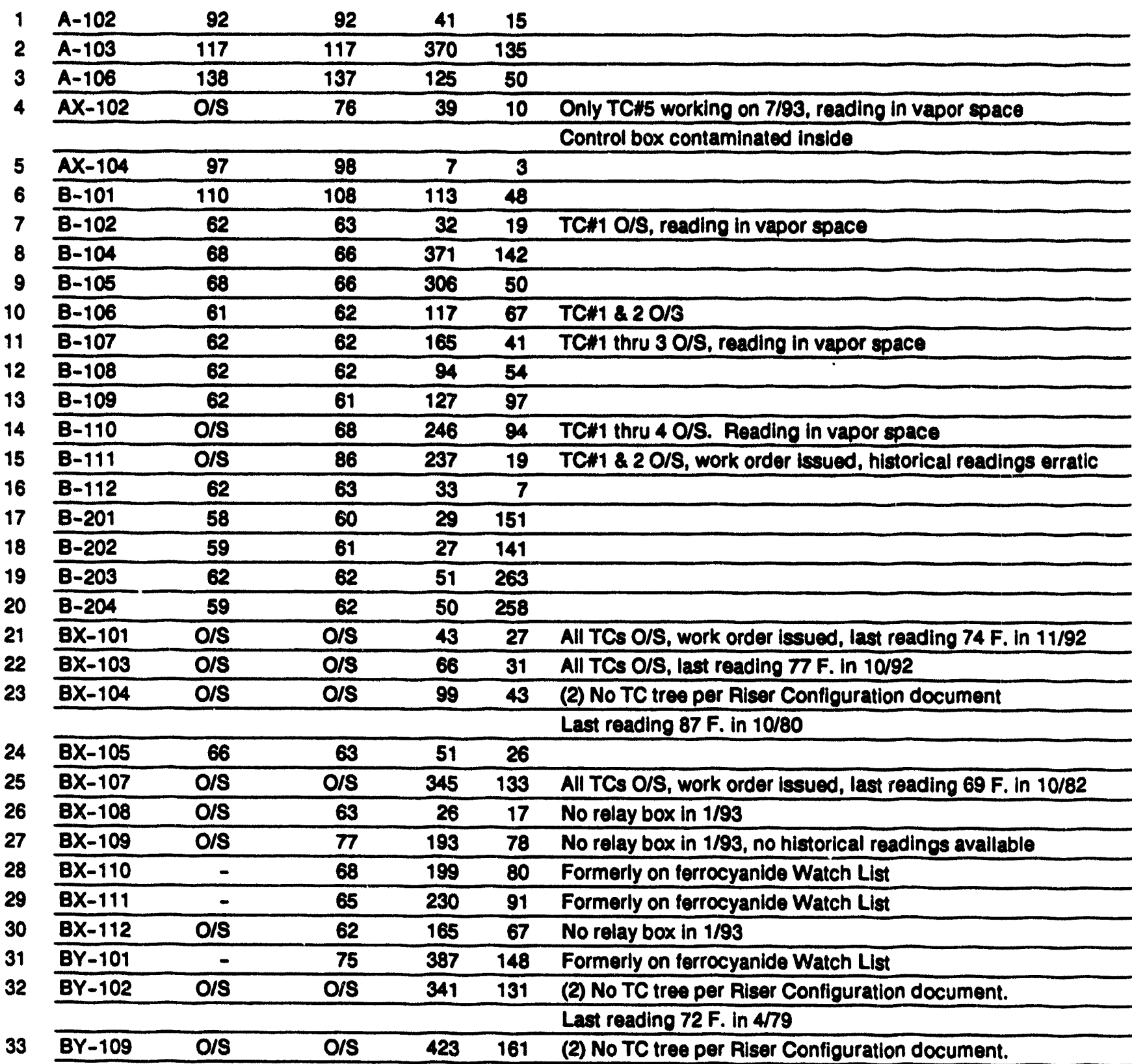




\section{TAELE A-6. NON-WATCH LIST LOW HEAT LOAD TANKS $(<40,000 \mathrm{Btu} / \mathrm{h})$ (Page 2 of 3)}

Temperatures are taken semiannually in January and July, unless otherwise indicated, in the following 96 single-shell tanks. Legend follows table.

\section{Highest Temperatures taken in waste Total Waste (1)}

Tank No. Jan. 93 Jul. 93 Kgal Inches

Comments

\begin{tabular}{|c|c|c|c|c|c|c|}
\hline 34 & C-101 & 91 & 88 & 88 & 39 & \\
\hline 35 & C-102 & O/S & O/S & 423 & 161 & Broken coupling, work order issued, last reading $96 \mathrm{~F}$. in 11/92 \\
\hline 36 & C-104 & 88 & 87 & 295 & 115 & TCW1 thru 5 O/S, reading in vapor space \\
\hline 37 & $\mathrm{C}-105$ & - & 92 & 150 & 63 & Monitored weekly, formerly on High Heat Load list \\
\hline \multirow[t]{2}{*}{38} & C-107 & - & 111 & 275 & 107 & Monthly reading requirement per procedure, monitored \\
\hline & & & & & & weekly \\
\hline 39 & C-110 & 65 & 65 & 187 & 75 & TC\#1 thru $4 \mathrm{O} / \mathrm{S}$, reading in vapor space \\
\hline 40 & C-201 & 60 & 61 & 2 & 13 & \\
\hline 41 & C-202 & 58 & 61 & 1 & 8 & \\
\hline 42 & C-203 & 58 & 60 & 5 & 29 & \\
\hline 43 & C-204 & O/S & O/S & 3 & 18 & No hookup to tree, last reading prior to ' 91. \\
\hline 44 & S-101 & O/S & 115 & 427 & 162 & TC\#1, 3,5, \&6 O/S, work order issued \\
\hline 45 & S-103 & 88 & 85 & 248 & 98 & \\
\hline 46 & S-104 & 108 & 104 & 294 & 114 & \\
\hline 47 & S-105 & 77 & 73 & 456 & 173 & \\
\hline 48 & S-106 & 81 & 78 & 543 & 205 & \\
\hline 49 & S-107 & 106 & 107 & 368 & 129 & \\
\hline 50 & S-108 & 87 & 85 & 604 & 227 & \\
\hline 51 & S-109 & 83 & O/S & 568 & 214 & All TCs O/S \\
\hline 52 & S-110 & 117 & 116 & 390 & 149 & \\
\hline 53 & $5 X-113$ & 75 & 73 & 26 & 15 & \\
\hline 54 & $S X-115$ & O/S & O/S & 12 & 10 & (2) No TC junction box, last reading prior $12 / 91$ \\
\hline 55 & $T-101$ & - & 66 & 102 & 45 & Formerly on ferrocyanide Watch List \\
\hline \multirow[t]{2}{*}{56} & $\mathrm{~T}-102$ & O/S & O/S & 32 & 19 & (2) No TC tree per Aiser Configuration document, \\
\hline & & & & & & last reading 68 F. in $2 / 81$ \\
\hline 57 & $T-103$ & 58 & 59 & 27 & 17 & \\
\hline 58 & $T-104$ & 62 & O/S & 445 & 169 & All TCs O/S, work order issued \\
\hline 59 & $T-105$ & O/S & O/S & 98 & 43 & (2) No TC tree per Riser Configuration document \\
\hline 60 & $T-106$ & 58 & 59 & 21 & 15 & \\
\hline \multirow[t]{2}{*}{61} & $T-108$ & O/S & O/S & 180 & 73 & All TCs O/S, TC tree laying on ground, J-3 issued 1/92 \\
\hline & & & & & & and again $7 / 93$, last reading $63 \mathrm{~F}$. in 11/91 \\
\hline 62 & $T-109$ & O/S & O/S & 58 & 29 & All TCs O/S, work order issued, last reading $75 \mathrm{~F}$. in $2 / 91$ \\
\hline 63 & $T-111$ & 62 & 59 & 458 & 174 & TCs $\# 1,2,5,60 / S$ \\
\hline 64 & $T-112$ & 62 & 58 & 67 & 32 & \\
\hline 65 & $T-201$ & 61 & 59 & 29 & 150 & \\
\hline 66 & $\mathrm{~T}-202$ & 61 & 58 & 21 & 110 & \\
\hline 67 & $T-203$ & 61 & 75 & 35 & 182 & \\
\hline 68 & T-204 & 62 & 60 & 38 & 197 & \\
\hline
\end{tabular}


WHC-EP-0182-68

\section{TABLE A-6. NON-WATCH LIST LOW HEAT LOAD TANKS $(<40,000 \mathrm{Btu} / \mathrm{h})$}

(Page 3 of 3)

Temperatures are taken semiannually in January and July, unless otherwise indicated, in the following 96 single-shell tanks. Legend follows table.

\section{Highest Temperatures}

taken in waste Total Waste (1)

Tank No. Jan. 93 Jul. 93 Kgal Inches

69

70

71

72

$\begin{array}{lll}0 / 5 & 87 & 39\end{array}$

TX-101

$T X-102$

TX-103

$T X-104$

TX-106

$T X-107$

$T X-108$

$T X-109$

$T X-110$

$T X-111$

$T X-112$

$T X-113$

$T X-114$

$T X-115$

$T X-116$

$T X-117$

$T Y-102$

$\pi \gamma-105$

$T Y-105$

$U-101$

$\mathrm{U}-102$

$\mathrm{U}-104$

$\mathrm{U}-110$

$U-112$

$U-102$

$U-202$

$\mathrm{U}-203$

$U-204$
O/S

O/S

O/S

71

64

80

67

67

65

97

81

81

73

72

73

O/S

O/S

70

o/s

O/S

O/S

75

75

66

88

O/S

81

$0 / 9$

$0 / 5$

60

O/S

O/S

60

59

59

O/S

O/S

$113 \quad 49$

49

$55 \quad 157$

$157 \quad 54$

$65 \quad 31$

$59 \quad 453$

$60 \quad 36 \quad 21$

$\begin{array}{lll}64 & 384 & 147\end{array}$

147

$462 \quad 175$

$\begin{array}{lll}65 & 607 & 228\end{array}$

O/S $\quad 535 \quad 202$

202

$\begin{array}{lll}\text { O/S } & 631 & 237\end{array}$

$\begin{array}{lll}77 & 231 & 91\end{array}$

$\begin{array}{lll}60 & 17 & 14\end{array}$

$\begin{array}{rrr}61 & 25 & 17 \\ 81 & 374 & 143\end{array}$

$\begin{array}{rrr}81 & 374 & 143 \\ 0 / 5 & 122 & 52\end{array}$

\begin{tabular}{rrr}
$0 / 5$ & 122 & 52 \\
\hline 72 & 186 & 75
\end{tabular}

$\begin{array}{lll}61 & 49 & 25\end{array}$

O/S $\quad 5$

529

\begin{tabular}{rrr}
59 & 5 & 29 \\
\hline O/S & 3 & 18 \\
80 & 3 & 18
\end{tabular}

(2) No TC tree per Riser Configuration document 49 Cable cut from tree

172 Cable cut from tree, readings taken by Instrument Technician

21 Cable cut from tree, readings taken by Instrument Technician

$61 \quad 134 \quad 56$ Cable cut from tree, readings taken by Instrument Technician

Cable cut from tree, readings taken by Instrument Technician

$\begin{array}{llll}61 & 370 & 142 & \text { Cable cut from tree, readings taken by Instrument Technician }\end{array}$

Cable cut from tree, readings taken by Instrument Technician

$\begin{array}{llll}72 & 649 & 243 & \text { Cable cut from tree, readings taken by Instrument Technician }\end{array}$

Dial pushed inside housing, readings taken by Instr. Tech.

Cable cut from TC tree

$67 \quad 640 \quad 240$ Dial pushed inside housing, readings taken by Instr. Tech.

(2) Tree cut off in riser per Riser Configuration document

O/S $\quad 626 \quad 235$ All TCs O/S, cable cut from tree

(2) No TC tree per Riser Configuration document

9

AII

All TCs O/S, work order written, last reading $66 \mathrm{~F}$. in $11 / 92$

(1) See Table A-2 (footnote $\sigma$ ) for waste gallons/inches calculations.

(2) Thermocouples in nine tanks (BX-104, BY-102, BY-109, SX-115, T-102, T-105, TX-101, TX-116, and U-104) are out of service due to no TC trees in these tanks, or the thermocouples have been cut off, covered over, or are otherwise unable to function, per the Riser Configuration document. (Also see comment section above)

KC-Thermocos

TC - Thermocouple

O/S - Out of service
Riser Configuration document - WHC-SD-RE-TI-053, REV 8, "Riser Configuration Document for Single-Shell Tanks," September 1991 Roadings oblain

Readings obtained in July 1993

No readings (TC trees O/S - includes nine

tanks with no trees - see footnote above)

Total low heat load tanks

\section{Tanks}

71

25

$\frac{25}{96}$ (U-111 was added to Organics Watch List, August 1993) 


\title{
TABLE A-7. SINGLE-SHELL TANKS MONITORING COMPLIANCE STATUS
}

\author{
149 TANKS (Sheet 1 of 5)
}

The following table indicates whether Single-Shell tank monitoring was in compliance with the requirements as specified in the applicable documents as of the last day of the applicable month:

NOTE:

All Watch List and High Heat tank temperature monitoring is in compliance. (5)

All Dome Elevation Survey monitoring is in compliance.

All Drywell monitoring is in compliance.

Psychrometrics (2)

In-tank Photographs (3)

Pressure Monitoring ( $($ )

CAM/RAMP Monitoring (7)

Vapor Monitoring (8)

Information as of $11 / 30 / 93$

\begin{tabular}{|c|c|c|c|c|c|c|c|c|c|}
\hline \multirow{4}{*}{$\begin{array}{l}\text { Tank } \\
\text { Number }\end{array}$} & \multirow{2}{*}{\multicolumn{2}{|c|}{ Cateoory }} & \multirow{4}{*}{$\begin{array}{c}\text { Temperature } \\
\text { Readings } \\
\text { (5)(6) }\end{array}$} & \multirow{3}{*}{\multicolumn{2}{|c|}{$\begin{array}{l}\text { Surface Level } \\
\text { Readings (1) } \\
\text { (-357) }\end{array}$}} & \multirow{4}{*}{$\begin{array}{l}\text { LOW } \\
\text { Roedings } \\
\text { (-357) (9) } \\
\text { Neutron } \\
\end{array}$} & \multicolumn{2}{|c|}{ Radiation Readings } & \multirow{4}{*}{$\begin{array}{l}\text { Dome } \\
\text { Elevation } \\
\text { Surveys } \\
\text { (OSRYSAR) }\end{array}$} \\
\hline & & & & & & & \multirow{3}{*}{$\begin{array}{c}\text { Lateral } \\
\text { Poadings } \\
(-357) \\
\end{array}$} & \multirow{3}{*}{$\begin{array}{l}\text { Drywell } \\
\text { Rosdings } \\
\text { (OsRysar) } \\
\end{array}$} & \\
\hline & \multirow{2}{*}{$\begin{array}{l}\text { Watch } \\
\text { List(6) }\end{array}$} & \multirow{2}{*}{$\begin{array}{l}\text { High } \\
\text { Heat }\end{array}$} & & & & & & & \\
\hline & & & & M.I. & FIC & & & & \\
\hline$A-101$ & $x$ & & & & $\sin x$ & & orc & & \\
\hline$A-102$ & & & & 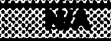 & 聯森兹 & 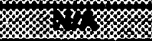 & OrC & & \\
\hline$A-103$ & & & & Xr. & x & 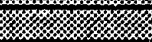 & $\overline{O N C}$ & & \\
\hline$A-104$ & & $\bar{x}$ & & 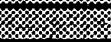 & 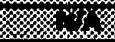 & 桨'Y & & & \\
\hline$A-105$ & & $\bar{x}$ & & 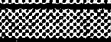 & 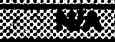 & 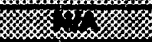 & & & \\
\hline$A-100$ & & & & $x y$ & $x$ & $x$ & & & \\
\hline Ax-101 & $\bar{x}$ & & & $2 \cos x$ & & 誃䀤 & & & \\
\hline$A x-102$ & & & & & 4 & 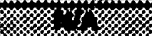 & & & \\
\hline$\overline{x-103}$ & $\bar{x}$ & & & serns & & 37 & & & \\
\hline$A x-104$ & & & & & sy sy & xys & & & \\
\hline$B-101$ & & & & 56 & OC & $y^{2}$ & & & \\
\hline$B-102$ & & & & 4 & & 3 & & & \\
\hline$B-103$ & $\bar{x}$ & & & (n) & & S1, & & & \\
\hline$B-104$ & & & & & 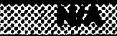 & 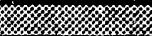 & & 卒蕜 & 淬 \\
\hline B-105 & & & & "x & $x y$ & & & & \\
\hline $8-106$ & & & & 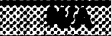 & & 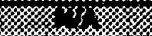 & & & \\
\hline $8-107$ & & & & & Kry & 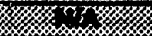 & & & s' \\
\hline$B-108$ & & & & sy; & Ore & $4 \times$ & & & \\
\hline$B-100$ & & & & 裂 & 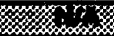 & rrop & & & \\
\hline $8-110$ & & & & & $8 \% 3$ & 43 & & & \\
\hline$B-111$ & & & & 43 & Ore & 43 & & & \\
\hline$B-112$ & & & & ry & & $4 \%$ & 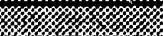 & 多亲 & \\
\hline$B-201$ & & & & & 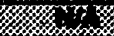 & 43 & & & \\
\hline$B-202$ & & & & & $y^{3}$ & 8 & & & \\
\hline$B-203$ & & & & & $4 x$ & $2 \sin$ & & & \\
\hline$B-204$ & & & & & 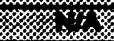 & $x_{3}^{2}$ & & 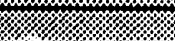 & \\
\hline$B X-101$ & & & OFC & & 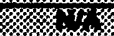 & $r y$ & & & \\
\hline$B X-102$ & $\bar{x}$ & & & & Ys? & $x$ & & & \\
\hline$B X-103$ & & & ore & sysis & & 83 & & צ' & \\
\hline$B \overline{x-104}$ & & & Or-OKC & ry & & $x y$ & & xy & \\
\hline BX-105 & & & & $5 x$ & & 3) & & & \\
\hline $8 x-106$ & $\bar{x}$ & & & 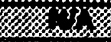 & & 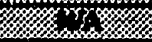 & & & \\
\hline$B x-107$ & & & OC & 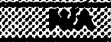 & ONC & 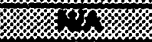 & & & \\
\hline
\end{tabular}

\begin{tabular}{|c|c|}
\hline \multirow{2}{*}{ LEGEND: } & \\
\hline & $=$ in compliance with all applicable documentation \\
\hline ON & = out of compliance with documentation \\
\hline-357 & $\begin{array}{l}=\text { WHC-SD-WM-Th-357. "Watto Storage Tank Status and Loak } \\
\text { Detection Criterie" }\end{array}$ \\
\hline POP & $\begin{array}{l}=\text { Plant Operetion Procedure TO-040-650, "Obeain/Record SST } \\
\text { Temperatures" }\end{array}$ \\
\hline M.T. & = Manud Tape \\
\hline & = Food Inctrument Corporation \\
\hline OSPSAR & 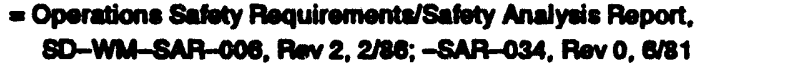 \\
\hline OSO & = Operating Epecifications Doc., OSD-T-151-00013, Rov D-0, 8/80 \\
\hline & - Not epplicablo (1.0., no LOW, M.T., FIC inctalled) \\
\hline Noutron & - LOW readings tuken by Neutron probe \\
\hline
\end{tabular}

Noutron $\quad=$ LOW readings teken by Neutron probe 
TABLE A-7. SINGLE-SHELL TANKS MONITORING COMPLIANCE STATUS 149 TANKS (Sheet 2 of 5 )

Information as of 11/30/93

\begin{tabular}{|c|c|c|c|c|c|c|c|c|c|}
\hline \multirow{4}{*}{$\begin{array}{l}\text { Tank } \\
\text { Number }\end{array}$} & \multirow{2}{*}{\multicolumn{2}{|c|}{ Category }} & \multirow{4}{*}{$\begin{array}{c}\text { Temperature } \\
\text { Readings } \\
\text { (5)(6) }\end{array}$} & \multirow{3}{*}{\multicolumn{2}{|c|}{$\begin{array}{l}\text { Surface Level } \\
\text { Peadings (1) } \\
\text { (-357) }\end{array}$}} & \multirow{4}{*}{$\begin{array}{l}\text { LOW } \\
\text { Readings } \\
(-357)(9) \\
\text { iedton }\end{array}$} & \multicolumn{2}{|c|}{ Radiation Readings } & \multirow{4}{*}{$\begin{array}{l}\text { Dome } \\
\text { Elevation } \\
\text { Surveys } \\
\text { (OSRUSAR) }\end{array}$} \\
\hline & & & & & & & \multirow{3}{*}{$\begin{array}{c}\text { Lateral } \\
\text { Readings } \\
(-357)\end{array}$} & \multirow{3}{*}{$\begin{array}{l}\text { Drywell } \\
\text { Readings } \\
\text { (OSPUSAR) }\end{array}$} & \\
\hline & Watch & High & & & & & & & \\
\hline & List(6) & Heat & & M.T. & FIC & & & & \\
\hline $8 x-108$ & & & & & $\overline{x y}$ & 3. & 桨桨 & & \\
\hline $8 x-100$ & & & & 85 & & s. & $x x^{2}$ & & \\
\hline $8 x-110(4)$ & & & & & $3 r$ & $\frac{1}{3}$ & 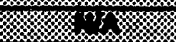 & & \\
\hline $8 x-111(4)$ & & & & & 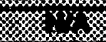 & & $x$ & & \\
\hline $8 X-112$ & & & & 安 & & Y & $x$ & & \\
\hline BY-101 (4) & & & & OC & 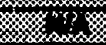 & 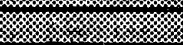 & 3 & & \\
\hline BY-102 & & & OS-ONC & & 25 & & 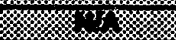 & & \\
\hline BY-103 & $\bar{x}$ & & & & $x, y$ & & $x$ & & \\
\hline BY-104 & $\bar{x}$ & & & 纱 & $5 x$ & & $r y$ & & \\
\hline BY-105 & $\bar{x}$ & & & & 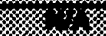 & & 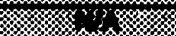 & & \\
\hline$B Y-100$ & $\bar{x}$ & & 纱炆 & 淬㡅 & 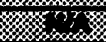 & r女s & $\sin _{1}^{2}$ & & \\
\hline BY-107 & $\bar{x}$ & & & & $x$ & & $x$ & & \\
\hline $8 Y-108$ & $\bar{x}$ & & 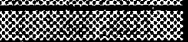 & & rsis & $4 x$ & $8 y^{2}$ & & \\
\hline BY-100 & & & Ors-ore & $x$ & & & $x$ & & \\
\hline$B Y-110$ & $\bar{x}$ & & & 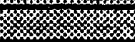 & s. & 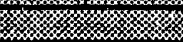 & 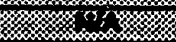 & 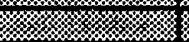 & 䘫 \\
\hline BY-111 & $\bar{x}$ & & 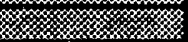 & $x$ & 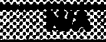 & xy & 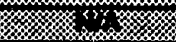 & & \\
\hline BY-112 & $\bar{x}$ & & & & 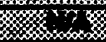 & Orc & $x=$ & & \\
\hline C-101 & & & & & 而 & xysy & W & & \\
\hline$\overline{c-102}$ & & & OC & Yrs & 饻 & $\sin$ & 11 & 858 & \\
\hline C-103 & $\bar{x}$ & & & rit & 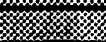 & 3 & (1) & 纹 & \\
\hline$C-104$ & & & & rys & 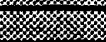 & 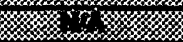 & 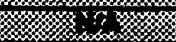 & 经 & \\
\hline C-105 & & & & zks & 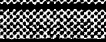 & 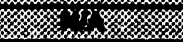 & 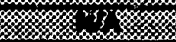 & & \\
\hline$C-100(4)$ & $\bar{x}$ & $\bar{x}$ & & $x y$ & 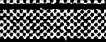 & 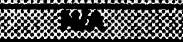 & món & & \\
\hline$c-107$ & & & & 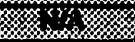 & 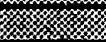 & $x$ & zk & 離 & \\
\hline $\mathrm{C}-108$ & $\bar{x}$ & & & $O 1 C(10)$ & 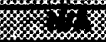 & $x$ & Kros & & \\
\hline $\mathrm{C}-100$ & $\bar{x}$ & & 隹 & & 4 & 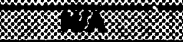 & $x+2, x$ & s.os & \\
\hline$c-110$ & & & & k & 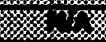 & xys & 15 & s. & \\
\hline$c-111$ & $\bar{x}$ & & & 婉帘 & 聯苭, & 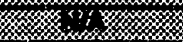 & $x y$ & & \\
\hline$c-112$ & $\bar{x}$ & & 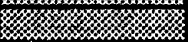 & 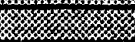 & $8 \pi$ & $x$ & $x$ & 将 & \\
\hline$C-201$ & & & & 悐 & sis & $x$ xys & 曻 & & \\
\hline $\mathrm{C}-2,02$ & & & & 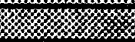 & $4 x^{2}$ & $x \sin x$ & $x^{3}, x_{1}$ & & \\
\hline$c-203$ & & & & 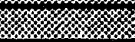 & $x_{i} ; x$ & $x$ & $x$ & 猝 & \\
\hline$c-204$ & & & ONC & 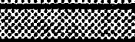 & $x_{0}$ & 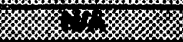 & $4 x_{2} x_{2}$ & & \\
\hline $5-101$ & & & & 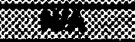 & 洨多 & & $x^{3}$ & 新 & \\
\hline $8-102$ & $\bar{x}$ & & & sons & & & $x_{1}$ & & \\
\hline $8-103$ & & & & $x y$ & ore & & $x, y$ & & \\
\hline $8-104$ & & & & & $5 \%$ & s.th & 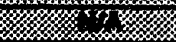 & & \\
\hline $5-105$ & & & & w. & S & 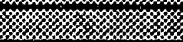 & Y $\}$ & & \\
\hline $8-106$ & & & Sxps & rerr & oc & 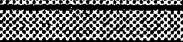 & $2 x_{3}^{1} x$ & & \\
\hline $8-107$ & & & & $y$ & & $y, x$ & $x y$ & & \\
\hline $8-108$ & & & & & & & $6 x$ & & \\
\hline $8-100$ & & & ONC & 3 & & & 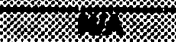 & & \\
\hline $8-110$ & & & & min & & & 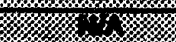 & & \\
\hline $8-111$ & $\bar{x}$ & & & $x y$ & & & 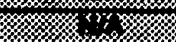 & & \\
\hline $8-112$ & $\bar{x}$ & & & $1 \times$ & & & 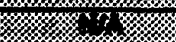 & & \\
\hline $8 x-101$ & $\bar{x}$ & & & $x=$ & & & 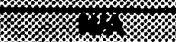 & & \\
\hline $8 x-102$ & $\bar{x}$ & & & ks.5 & & & 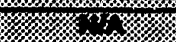 & & \\
\hline $8 x-103$ & $\bar{x}$ & & & 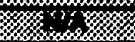 & 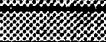 & & $x$ & & \\
\hline $8 x-104$ & $\bar{x}$ & & & Y & 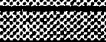 & Ore-ONC & 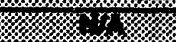 & & \\
\hline $8 x-105$ & $\bar{x}$ & & & sy $\$$ s & 誃㤠誃 & 誃誃 & ONC & & \\
\hline $8 x-106$ & $\bar{x}$ & & & 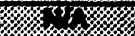 & Ore & & 8 & & \\
\hline $8 x-107$ & & $\bar{x}$ & & & 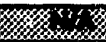 & 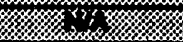 & Orc & & \\
\hline $8 x-108$ & & $\bar{x}$ & & 1 & $\sqrt{x} x$ & 多多 & OXC & & \\
\hline
\end{tabular}


TABLE A-7. SINGLE-SHELL TANKS MONITORING COMPLIANCE STATUS 149 TANKS (Sheet 3 of 5)

Information as of $11 / 30 / 93$

\begin{tabular}{|c|c|c|c|c|c|c|c|c|c|}
\hline \multirow{4}{*}{$\begin{array}{l}\text { Tank } \\
\text { Number }\end{array}$} & \multirow{2}{*}{\multicolumn{2}{|c|}{ Category }} & \multirow{4}{*}{$\begin{array}{c}\text { Temperature } \\
\text { Readings } \\
\text { (5)(0) }\end{array}$} & \multirow{3}{*}{\multicolumn{2}{|c|}{$\begin{array}{c}\text { Surface Level } \\
\text { Readings (1) } \\
\text { (-357) }\end{array}$}} & \multirow{4}{*}{$\begin{array}{l}\text { Low } \\
\text { Readings } \\
(-357)(9) \\
\text { Neution }\end{array}$} & \multicolumn{2}{|c|}{ Radiation Readings } & \multirow{4}{*}{$\begin{array}{l}\text { Dome } \\
\text { Elevation } \\
\text { Surveys } \\
\text { (OSPUSAR) }\end{array}$} \\
\hline & & & & & & & \multirow{3}{*}{$\begin{array}{c}\text { Lateral } \\
\text { Readings } \\
(-357)\end{array}$} & \multirow{3}{*}{$\begin{array}{l}\text { Drywell } \\
\text { Readings } \\
\text { (OSPISAP) }\end{array}$} & \\
\hline & \multirow{2}{*}{$\begin{array}{l}\text { Watch } \\
\text { List(6) }\end{array}$} & \multirow{2}{*}{$\begin{array}{l}\text { High } \\
\text { Heat }\end{array}$} & & & & & & & \\
\hline & & & & Th.T. & FIC & & & & \\
\hline $8 x-100(4)$ & $\bar{x}$ & $x$ & & & Xry & ry & OXC & & \\
\hline $8 x-110$ & & $\bar{x}$ & & & r.s. & Yx & OK & & \\
\hline$S x-111$ & & $\bar{x}$ & & & ror & sy & OKC & & \\
\hline $8 x-112$ & & $\bar{x}$ & & & $x$ & $x$ & OC & & \\
\hline $8 x-113$ & & & & & 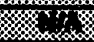 & $x$ & res & & \\
\hline $5 x-114$ & & $\bar{x}$ & & & $x$ & $x$ & ONC & & \\
\hline $5 x-115$ & & & OS-OKC & k & $x$ & 要 & का & & \\
\hline$T-101(6)$ & & & & s & & $x$ & $x$ & & \\
\hline$T-102$ & & & $018-0 / C$ & $x_{0} x_{x}$ & Or & $x$ & 15 & & \\
\hline$T-103$ & & & & 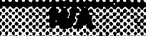 & & 3 & $\left.x^{3}\right\}$ & & \\
\hline$T-104$ & & & orc & & $83^{3}$ & & 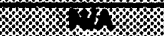 & & \\
\hline$T-105$ & & & Os-OC & 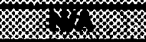 & & $x$ & $x$ & & 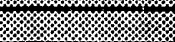 \\
\hline$T-100$ & & & & $r y$ & & $x$ & $x$ & & \\
\hline$T-107$ & $\bar{x}$ & & & $x=3$ & & 3 & $8>3$ & & \\
\hline$T-103$ & & & OrC & & $x$ & $\frac{1}{25 r}$ & $x+3$ & & \\
\hline$T-100$ & & & Orc & ry. & $x$ & $x$ & $x$ & & \\
\hline$T-110$ & $\bar{x}$ & & 努嬨 & 2 & 慈 & 曻慈 & $r x$ & & \\
\hline$T-181$ & & & 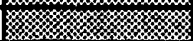 & xis & 摔 & $x$ & $x y$ & & \\
\hline$T-112$ & & & & 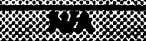 & 聯 & $\mathrm{r}^{1}$ & $3 r y$ & & \\
\hline$T-201$ & & & & 㶌 & 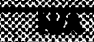 & xis & $x>y$ & & \\
\hline$T-202$ & & & & orc & SY & $x$ & rery & & \\
\hline$T-203$ & & & & & 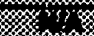 & $x$ & 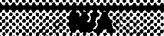 & & \\
\hline$T-204$ & & & & & $x y$ & $y^{r}$ & $\sqrt{3}\}$ & K & \\
\hline$\overline{x-101}$ & & & $O / S-O / C$ & $x$ & Orc & $x$ & $x^{x}, y$ & & \\
\hline $7 x-102$ & & & OKC & & Yry & & $x^{3} \times$ & & \\
\hline $7 x-103$ & & & & $x \rightarrow y$ & & $x y$ & $x>\gamma$ & & \\
\hline $7 x-104$ & & & & $x^{\prime}$ & & $\langle \%$ & 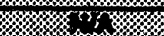 & & \\
\hline $7 x-105$ & $\bar{x}$ & & & & $8 x y$ & $O O^{S}-O C$ & $8 \times$ & & \\
\hline $7 x-100$ & & & & & 8 & & $2 \ln$ & & \\
\hline $7 x-107$ & & & & $4 \%$ & & $x>$ & 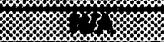 & & \\
\hline $7 x-108$ & & & & sins & 经 & $\gamma_{2}$ & $x$ & & \\
\hline $7 x-100$ & & & & $\gamma_{;}^{\prime}$ & 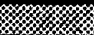 & & $2 y$ & & \\
\hline $7 x-110$ & & & Orc & & $8 \%$ & & 878 & & \\
\hline$\overline{T x-111}$ & & & & & 3 & xy & 83,3 & & \\
\hline$T x-112$ & & & & $x$ & 35 & & $8 \sin$ & & \\
\hline$\overline{7 x-113}$ & & & & & $x y$ & & $<3$ & & \\
\hline $7 x-114$ & & & OrC & & $x$ & & XYYY & & \\
\hline $7 x-115$ & & & & & 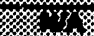 & & $x$ & & \\
\hline $7 x-116$ & & & Ors OKC & & $2 T^{3 / 2}$ & $\forall m$ & 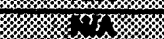 & & \\
\hline $7 x-117$ & & & OC & $\operatorname{ses} x$ & $x$ & & $x$ & & \\
\hline $7 x-118$ & $\bar{x}$ & & & $x$ & & & 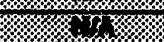 & & \\
\hline$T Y-101$ & $\bar{x}$ & & & 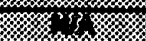 & & 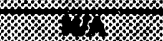 & 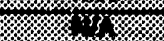 & & \\
\hline$T \gamma-102$ & & & Orc & $8 \pi$ & & $x y$ & $x y$ & & \\
\hline$T Y-103$ & $\bar{x}$ & & & ysty & & $x$ & $x$ & & \\
\hline$T Y-104$ & $\bar{x}$ & & & 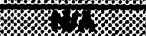 & & YY. & $\langle y$ & & \\
\hline$T Y-106$ & & & & & 3 & 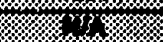 & $x$ & & \\
\hline$T Y-108$ & & & & & 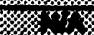 & $x$ & 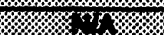 & & \\
\hline$U-101$ & & & & Ore & $x$ & 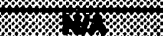 & $x$ & & \\
\hline U-102 & & & & XIS & & 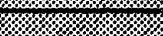 & $x$ & & \\
\hline U-103 & $\bar{x}$ & & & Y 5 & & & $95 \%$ & & \\
\hline U-104 & & & O/S - ORC & & 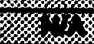 & sry & $x$ & & \\
\hline U-105 & $\bar{x}$ & & & 4 & & & $x$ & & \\
\hline$U-106$ & $\bar{x}$ & & & $6 x$ & & & 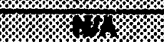 & & \\
\hline
\end{tabular}


HHC-EP-0182-68

TABLE A-7. SINGLE-SHELL TANKS MONTORING COMPLIANCE STATUS 149 TANKS (Sheet 4 of 5)

Information as of 11/30/93

\begin{tabular}{|c|c|c|c|c|c|c|c|c|c|}
\hline \multirow{4}{*}{$\begin{array}{l}\text { Tank } \\
\text { Number }\end{array}$} & \multirow{2}{*}{\multicolumn{2}{|c|}{ Category }} & \multirow{4}{*}{$\begin{array}{c}\text { Temperature } \\
\text { Readings } \\
\text { (5)(6) }\end{array}$} & \multirow{3}{*}{\multicolumn{2}{|c|}{$\begin{array}{l}\text { Surface Level } \\
\text { Readinge (1) } \\
\text { (-357) }\end{array}$}} & \multirow{4}{*}{$\begin{array}{c}\text { LOW } \\
\text { Readings } \\
(-357)(9) \\
\text { Neutron }\end{array}$} & \multicolumn{2}{|c|}{ Radiation Readings } & \multirow{4}{*}{$\begin{array}{l}\text { Dome } \\
\text { Elevation } \\
\text { Surveys } \\
\text { (OSR/SAR) }\end{array}$} \\
\hline & & & & & & & \multirow{3}{*}{$\begin{array}{c}\text { Lateral } \\
\text { Readings } \\
(-357)\end{array}$} & \multirow{3}{*}{$\begin{array}{c}\text { Drywell } \\
\text { Roadings } \\
\text { (OSAJSAR) }\end{array}$} & \\
\hline & \multirow{2}{*}{$\begin{array}{l}\text { Watch } \\
\text { List(6) }\end{array}$} & \multirow{2}{*}{$\begin{array}{l}\text { High } \\
\text { Heat }\end{array}$} & & & & & & & \\
\hline & & & & M.T. & FIC & & & & \\
\hline U-107 & $x$ & & & xis & & & 紧 ry & & \\
\hline U-10s & $\overline{\mathbf{x}}$ & & & 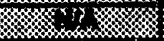 & & & 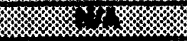 & & \\
\hline U-100 & $\overline{\mathbf{x}}$ & & & r. & ঋ & & 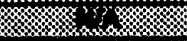 & & \\
\hline$\sqrt{-110}$ & & & & X & - & 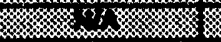 & $x^{2}$ & & \\
\hline U-111 & $\bar{x}$ & & & 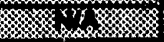 & & & 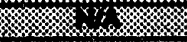 & & \\
\hline U-112 & & & & & 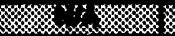 & $2 y$ & $3<$ & & \\
\hline U-201 & & & OK & & 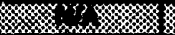 & 3 & $8 x$ & & \\
\hline U-202 & & & & & (x) & 23 & sis & & \\
\hline$U-203$ & & & OKC & & 登 & 3 & 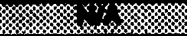 & & \\
\hline $\mathbf{U - 2 0 4}$ & & & & & (1) & $y$ & 8 & & \\
\hline \multicolumn{10}{|c|}{ Catch Tanks and Special Surveillance Facilities } \\
\hline$A-502-A$ & WA & NA & 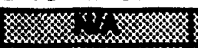 & 级 & & 13 & sing & 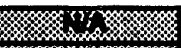 & rym \\
\hline A- & N/A & NA & $8 x$ & 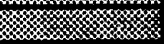 & ms & m & ryos & rys & rats \\
\hline 311-ER & Wh & N/A & $x$ & (1) & & 1;i & $\cos ^{2}$ & $x$ & 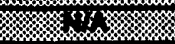 \\
\hline $152-A x$ & NA & N/A & chosh & & W & & & & \\
\hline $151-\sqrt{2}$ & Wh & NA & YYY & sons & $x$ & $x$ & 4 & $x^{2} / \mathrm{s}$ & 36 \\
\hline 154-N2 & NMA & NA & 货ry & & 次 & shons & stros & ros & 45 \\
\hline BX-TKESMP & NA & NA & $x^{3}$ & & 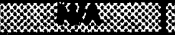 & & 2 & & \\
\hline ATRUEMP & NA & WA & 缁 & & m & & 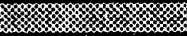 & 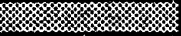 & \\
\hline 204-AA & NA & NA & - & & & 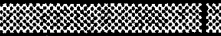 & 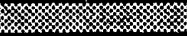 & & \\
\hline 117-A & N/A & N/A & 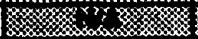 & 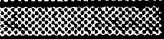 & & z & & 恼 & . \\
\hline Vent Ex. & N/A & N/A & 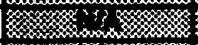 & 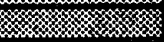 & 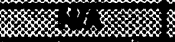 & 要 & $c_{1}^{\prime \prime}$ & $x^{2}$ & $x+16 x$ \\
\hline 8.02 & NWA & W/A & rys's & 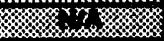 & & 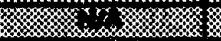 & 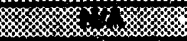 & 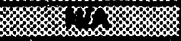 & $3 x$ \\
\hline S-02-A & N/A & N/A & 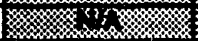 & 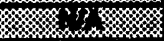 & or & 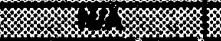 & $\left.x^{2}\right\} ?$ & 16 & 33 \\
\hline Sent & WA & NA & ry & & 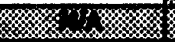 & $8^{2 r r}$ & n & 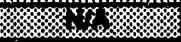 & 20 \\
\hline$T x-502-B$ & WA & $\mathbf{N} \mathbf{A}$ & 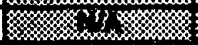 & & $x<y$ & s's & $8 x_{x}$ & $x+3$ & $x$ \\
\hline TX-302-C & Wh & Nh & $\cos r \cos$ & $x_{1}$ & 叒 & xys & strox & 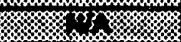 & $3 x$ \\
\hline U-S1-8 & NW & WA & $x$ & $x$ & Ore & 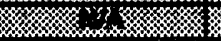 & 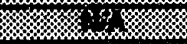 & 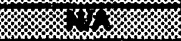 & 515 \\
\hline$U x-302-A$ & NA & WA & $x$ & 桨 Y\} & & 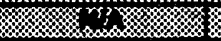 & 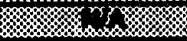 & 40 & (mons \\
\hline $141-6$ & NWA & N/A & $x+1\}$ & & s. & x r's's & $x$ & 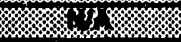 & $6 y$ \\
\hline $142-8$ & WA & NA & 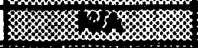 & & 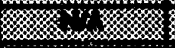 & 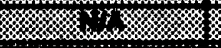 & 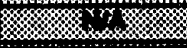 & 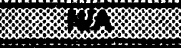 & 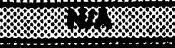 \\
\hline $\begin{array}{l}\text { Totals: } \\
140 \text { tanks }\end{array}$ & $\begin{array}{c}45 \\
\text { Watch } \\
\text { Lit } \\
\text { Tanke } \\
\text { (4) }\end{array}$ & $\begin{array}{l}10 \\
\text { High } \\
\text { Heat } \\
\text { Tanks } \\
\text { (4) }\end{array}$ & $\begin{array}{l}\text { Oc: } \\
25 \text { tanks - } \\
\text { (comiannual } \\
\text { monitoring } \\
\text { trequency) (5) }\end{array}$ & $\begin{array}{l}\text { Or: } \\
4 \text { tanks } \\
0 \text { catch tank }\end{array}$ & $\begin{array}{l}\text { Orc: } \\
\text { etanks } \\
2 \text { catoh tanks }\end{array}$ & $\begin{array}{l}\text { OrC: } \\
\text { 3tunks } \\
\text { Ss tanks havo } \\
\text { LOWe (2 are Ods) }\end{array}$ & $\begin{array}{l}\text { Oxc: } \\
12 \text { tanks }\end{array}$ & 0 & 0 \\
\hline
\end{tabular}

See Footnotes on next page 


\section{TABLE A-7. SINGLE-SHELL TANKS MONITORINO COMPLIANCE STATUS 149 TANKS (Sheet 5 of 5 )}

\section{Footnotes:}

1. All ssis have oither manual tepe or FIC, with the exception of s-108 and r-101, which have both. Tank 101-T also has zip cord. All ssT FICs are conneted to CAss, with the exception of BX-106; however, the comnection for many tanks is broken. For such cases, manual readings are taken. Manual surface level readings include readings taken by manual tape, manual Fic (not connected to CAss; 8X-106), manual readings of automatic FIC (if cass is printing "0"), or cutomatic FIC. In some cases, the surface level readings are taken wing a zip cord. While less accurate, such readinge ore acceptable for meeting the surfece level reading requirements.

2. High heat tanks have ective exhousters; peychromentics ore taken in these tanks (A-104/105, C-105/106 leffective July 1, 1993, C-105 is no longer a high heat load tank], sx-107, 108, 109, 110, 111. 112, and 114. The exhousters on A-104/105 have been down since October 1991; no readings are being taken. Psychrometric readings have not been taken in the $8 x$ high heat load tanks since July 1993. The frequency of peychrometric readings in SSTs is determined by the cognizant Engineers for the applicable tank farme on an "as needad" besis," with the exception of tanke C-105/106. Hanford Federal Facility Agreement and Consent Order," Washington state Department of Ecology, U. S. Environmental Protection Agency, and U. S. Department of Energy, 1992 (Tri-Party Agreement) requires peychrometric readings to be taken in C-105/106 on a monthly frequency. Last readings were taken october 27. 1993; readings were not taken in November. A Discrepancy Report was issued.

3. In-tank photographs are requented on an "as needed" basis. No in-tank photographs were taken between september 1990 and March 1993.

4. Two tanks ore on both category liste (C-106 and 5x-109). In July 1993, C-105 was removed from the High Heat Load list and BX-110, BX-111, BY-101 and T-101 were removed from the forrocyanide watch List. Only C-105 cont inues to be taken weekly; the other tanks are now taken semiannually. U-111 was added to the Organic salts list August 31, 1993.

5. Temperature readings ay be regulated by 0S0, -357 , or POP. Additionally, high heat load tanks ore regulated by OSR/SAR. Thermocouples in the nine tanks designated O/S-0/C are out of service; there are either no thermocouple trees in these tanks, or trees have been cut off, covered over, or are otherwise unable to function. The OSD does not require readings or repair of out-of service thermocouples for the 96 low heat laed $(240,000$ Btw/h) tenks. However, the POP requires that attempts are to be made semianmully in January and July to obtain readings for these tanks. Temperatures were taken in July 1993; a total of 25 tenks are O/C because either no attempt to obtain the temperature was made, or a reading could not be obtained.

6. MSafoty Measures for Waste Tanks at Hanford Muclear Reservation, Section 3137 of the National Defense Authorization Act for Fiscal Year 1991, "November 5, 1990, Publ ic Law 101-510, (the "Widen Amendment") requires continuous pressure monitoring and temperature monitoring in Watch List tanks. WHC-EP-0422 REV 1, "A PIan to Inplement Remediation of Waste Tank Safety Issues at the Hanford Site," December 1991, eddresses these monitoring issues. WHC-EP-0600, "Status Report on Resolution of Waste Tank Safety Issues at the Hanford Site," issued August 1993, describes the resolution strategy for these safety issues.

7. Continuous Air Monitoring (CAM) compliance and Radiation Area Monitoring Panel (RAMP) compliance are not addressed in this table.

8. Double-shell tank farm sy has the only tanks with continuous vapor/flemable gas monitoring; not addressed in this table.

9. An Engineering Change Notice was issued November 1993, changing the monitoring frequency of LOW readings by Gamm probe to be taken "by request only." The Gamma probe colum has therefore been deleted.

10. Surface level measurement monitoring is out of compliance in C-108 because the manual tape was renoved to install a thermocouple tree. This tank does not have an FIC. A work package is pending to re-install the manual tape. 
WHC-EP-0182-68

\section{TABLE A-8. DOUBLE-SHELL TANKS MONITORING COMPLIANCE STATUS 28 TANKS (Sheet 1 of 2)}

The following table indicates whether Double-shell tank monitoring was in compliance with the requirements as specified in the applicable documents as of the last day of the applicable month:

NOTE:

Domo Eevation Eurveye ere not required lor DETs.

Poyohrometrios (2)

In-tank Photographs (8)

Preccure Monitoring (O)

CAMEAMP Montioring (n)

Vapor Monitoring (B)

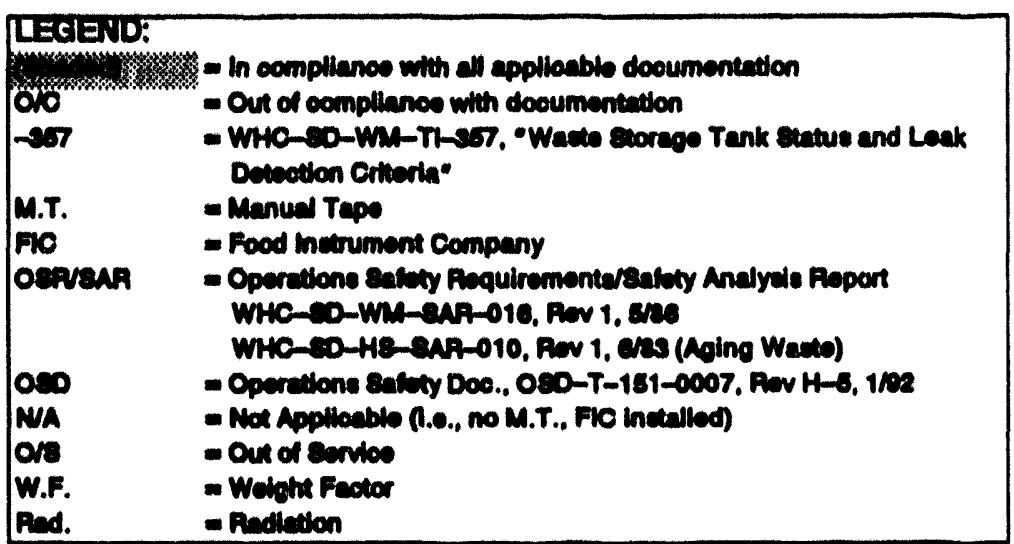

Information as of 11/30/9s

\begin{tabular}{|c|c|c|c|c|c|c|c|}
\hline \multirow{3}{*}{$\begin{array}{l}\text { Tank } \\
\text { Number }\end{array}$} & \multirow[b]{3}{*}{ Wrich Llet } & \multirow{3}{*}{$\begin{array}{c}\text { Temperature } \\
\text { Randinges } \\
(4) \\
(080)\end{array}$} & \multirow{2}{*}{\multicolumn{2}{|c|}{$\begin{array}{l}\text { Surtace Level } \\
\text { Readinges (1) } \\
\text { (-\$57, OSPSAP) }\end{array}$}} & \multicolumn{3}{|c|}{ Asdiation Readings } \\
\hline & & & & & \multicolumn{2}{|c|}{$\begin{array}{c}\text { Leak Detection } \\
\text { Plts (5) } \\
\text { (-\$57, OsA/3AR) }\end{array}$} & \multirow{2}{*}{$\begin{array}{c}\text { Annulus } \\
(-357)\end{array}$} \\
\hline & & & M.T. & FC & W.F. & Fed. & \\
\hline At-101 & & & wos & & 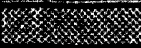 & onc & \\
\hline AL-102 & & $x$ & 纹 & 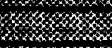 & 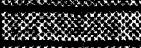 & OK & \\
\hline NF-105 & $\bar{x}$ & & r. & 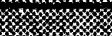 & & & \\
\hline 7F-104 & $\bar{X}$ & & xys & 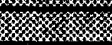 & & or & \\
\hline AN-106 & $\mathbf{X}$ & $z_{2}$ & 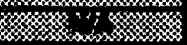 & 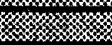 & r & OC & \\
\hline $2+100$ & & 玹 & $x$ x & & 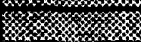 & OE & \\
\hline 2W-107 & & 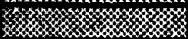 & 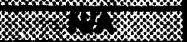 & 猡 & 空 & & \\
\hline AP-101 & & 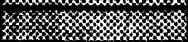 & 采 & & & Ore & \\
\hline$\lambda^{2}-102$ & & 玹 & k & 018 & & Ore & \\
\hline$A P=108$ & & 玹 & & 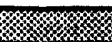 & 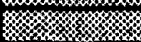 & Ore & \\
\hline$A^{2}-104$ & & 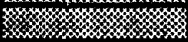 & Ors & 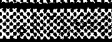 & 㽝 & Ox & ک \\
\hline A $=106$ & & Kx & 敟 & 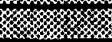 & & Ore & 约 \\
\hline $\mathbb{N}^{2}-100$ & & $x$ & & 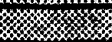 & & Ore & \\
\hline AP-107 & & $x$ & xy & 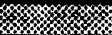 & 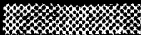 & OKC & \\
\hline AR-10 & & 纱䋟 & 级 & & 納玹 & Ore & \\
\hline AW-101 & $\bar{X}$ & 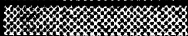 & & Ors & 誃 & & \\
\hline AW-102 & & & & क8 & 嬨 & & \\
\hline AW-103 & & 㧒 & & & 聯 & Ore & \\
\hline AW-104 & & & & & 誃誃 & OC & \\
\hline$A W-108$ & & & & Ors & 聯票 & OC & x қ \\
\hline$A W-100$ & & & & & & OK & \\
\hline$A Y-101$ & & & x & Ore & & & OKC \\
\hline AY-102 & & & & & & ON & ore \\
\hline $12-101$ & & & & Ors & $x$ & OC(0) & \\
\hline N-102 & & & & O/8 & & OK & \\
\hline $8 \gamma-101$ & $\bar{x}$ & 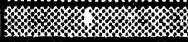 & & & & & \\
\hline $8 Y-102$ & & & & 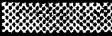 & 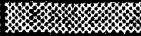 & 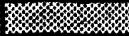 & \\
\hline $87-103$ & $\bar{x}$ & & & 留 & 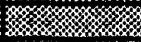 & & צ' \\
\hline $\begin{array}{l}\text { Totale: } \\
23 \text { tanks }\end{array}$ & $\begin{array}{c}6 \\
\text { Watch Lit Tanke }\end{array}$ & $\begin{array}{l}\text { ONC: } \\
0\end{array}$ & $\begin{array}{l}\text { ON: } \\
0\end{array}$ & $\begin{array}{l}\text { Oxc: } \\
0\end{array}$ & $\begin{array}{l}\text { orc: } \\
0\end{array}$ & $\begin{array}{l}\text { Orc: } \\
20 \text { tanks }\end{array}$ & $\begin{array}{l}\text { O/C: } \\
2 \text { tanke }\end{array}$ \\
\hline
\end{tabular}

See footnotes next page: 
TABLE A-8. DOUBLE-8HELL TANK8 MONITORINO COMPLIANCE 8TATUS 28 TANKS (Sheet 2 of 2 )

\section{Footnotes:}

1. All Dsts have both manul tape and FIC, with the exception of the AN Tenk Parm inleh has only Fics. The manul tepe is uned then the Fic is out of service. O/C will be shoin when no readings are cbtained.

2. Paychreantric readinge are only taken on tenks with ective exhewsters: oll Dste have active exhewsers. The frequency of payehrometric reedings in Dsts is determinud by the Coenizant Enginears for the coplfecble tenk form on en "as needad" besls. Currently, monthly rasedings are being taken on the sy-101 emulus exhawst, sy-102 tank and ennulus oxhaust, and sr-103 tank and emulu exhacet. sy-101 tenk exheust readings ore not bolng taken unt II a port on the tenk oxhaust hesder becones ovolleble for exhouster readinas. No other paychrometric readings are currently baing taken monthly.

3. In-tenk photographs are requested on en was noededu basls. Last in-tank photographs in DsTs were taken in April 1989.

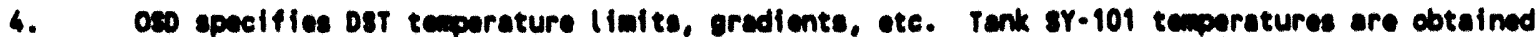
ahiftwise with increased readinge taken prior to and following gas venting.

5. Pollure of both lead detection syetem recuires repair of ot least one syetem within 5 working days. Failure of on evetem only, repair mut be within 10 workdoys. Par -337. If repoir of out-0 -

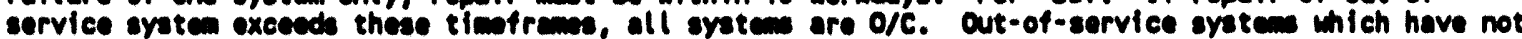
exceeded these timetremes will be shown os $0 / 8$.

6. Mgafety Masaures for Waste Tanks at Menford Muclear Reaervation, section 3137 of the Mational Defenee Authorization Act for Fiseal Year 1991." November 5, 19\%0, Publle Lew 101-510, (the "Widen Amendwent") requires cont inuous pressure monitoring and tcmporature monitoring in wateh List tanks. WHC-EP-0422 REV 1 " "A Plen to Implement Remediation of Waste Tenk safety lasuse at the Hanford site," Decenber 1991, eddresses these monitoring issues. A status report on resolution of Waste Tank safety Isewes at the Manford site has been prepered but has not yot been cleared for publie release.

7. Contimuous Alr Monitoring (CAN) compllence and Redietion Ares Monitoring Panal (RAMP) compl lence are not addressed in this table.

8. Double-shell tenk farm sy hes the only tenks with continuous vepor/flemenble gas monitoring; not addreased in this table.

9. Althowh date are being received for AZ-101, this information is considared qusetionable. 


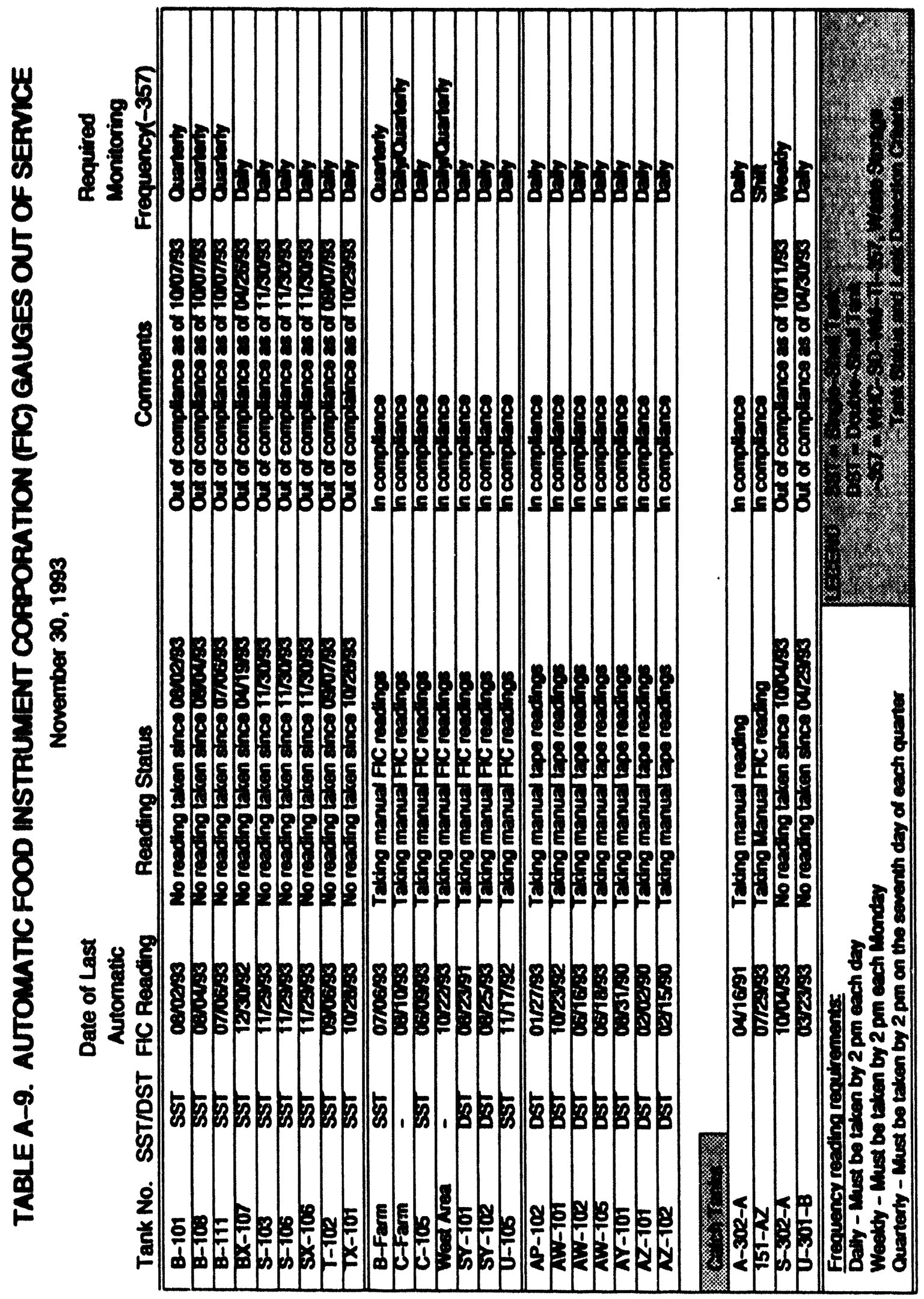




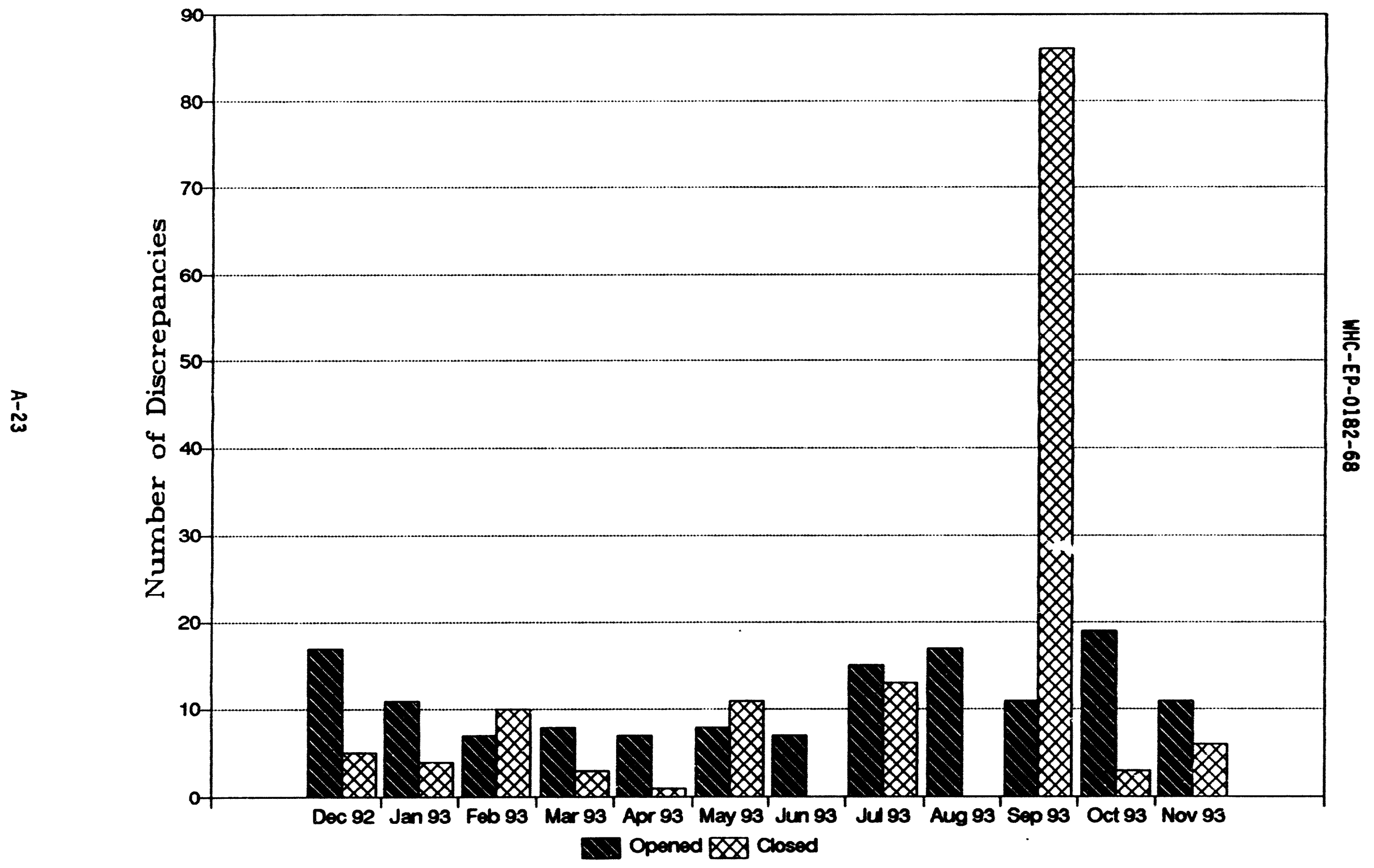

Figure 1. Discrepancy Report Status 


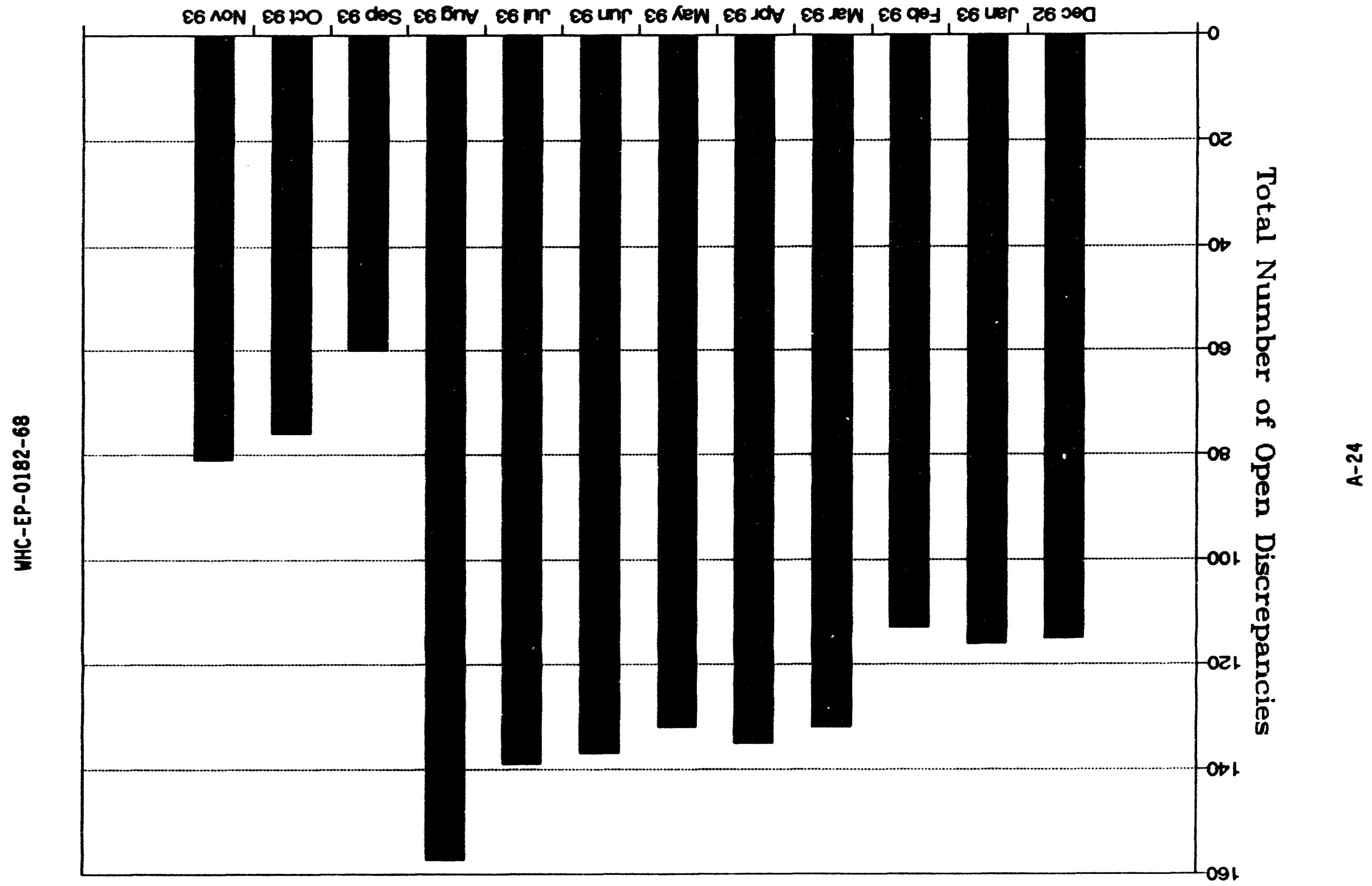




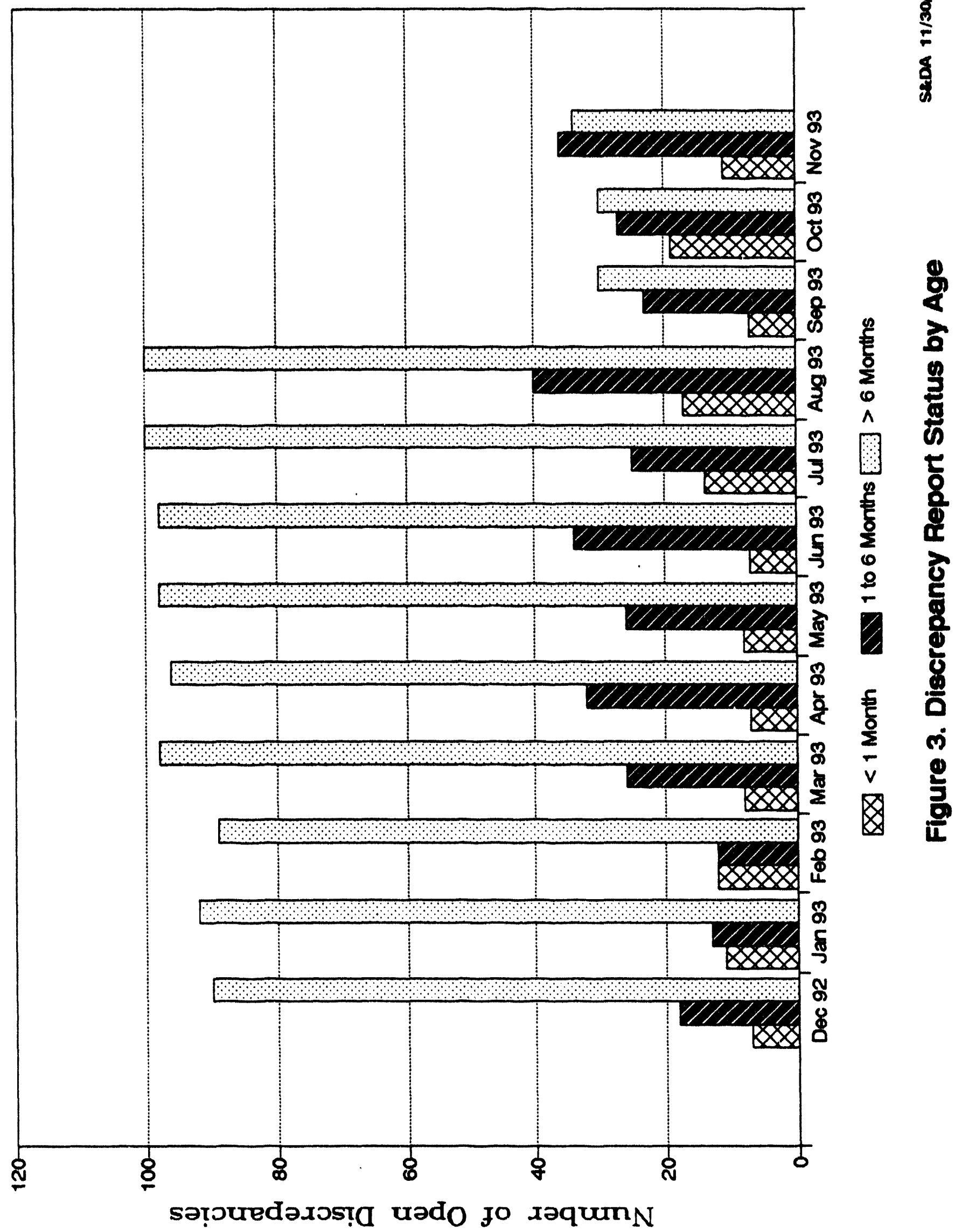




\section{MHC-EP-0182-68}

This page intentionally left blank 
WHC-EP-0182-68

APPENDIX B

DOUBLE SHELL TANK WASTE TYPE AND SPACE ALLOCATION 
WHC-EP-0182-68

This page intentionally left blank 
TABLE B-1. DOUBLE-SHELL TANK WASTE TYPE AND SPACE ALLOCATION NOVEMBER 1993

DOUBLE-SHELL TANK INVENTORY BY WASTE TYPE

SPACE DESIGNATED FOR SPECIFIC USE

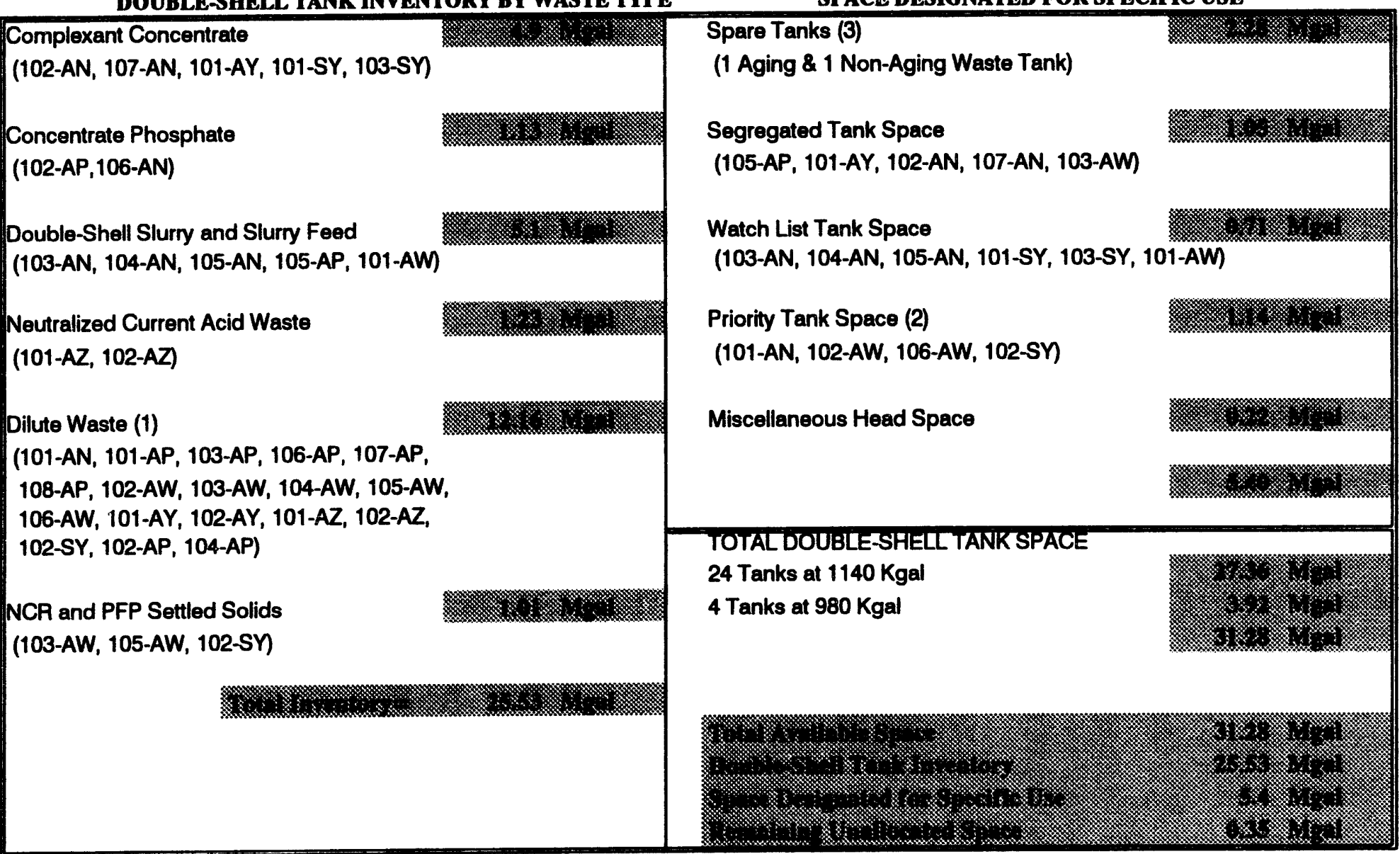

(1) Easily reduced in volume by Evaporator/LERF

(2) Reduced by Saltwell Liquid pumping, Mini Run and PFP Operations

(3) 241-101-AY: A minumum liquid level is set to provide extra protection against any bottom uplifting of the tank's steel liner. WHC-SD-WM-TI-357,

"Waste Storage Tank Status and Leak Detection Criteria," specifies 64 in. as the minimum surface level measurement when the annulus system is

in operation, and 18 in. if the annulus ventilation system is shut down. See also OSD-T-151-0007, "Unclassified Operation Specifications for the 241 AN, 241AP, 241AW, 241AY and 241SY Tank Farms." Because of space availablility, waste is stored in 102-AY, the aging waste spare tank. In case of a leak, the contents of 102-AY will be distributed to any other DST(s) having available space. 


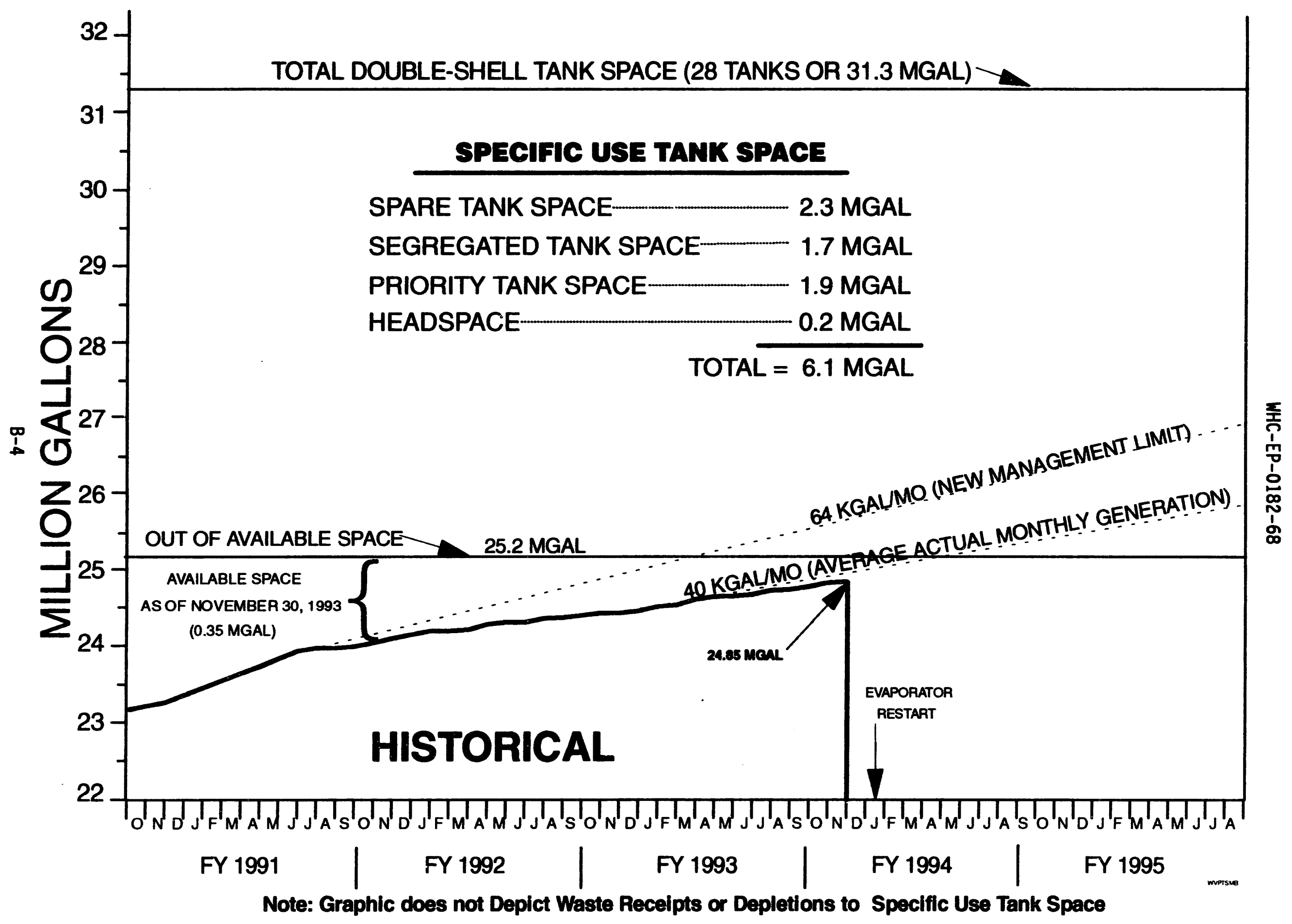

FIGURE B-1. CURRENT STATUS AND CONTINGENCY SPACE FOR THE 242-A EVAPORATOR RESTART 


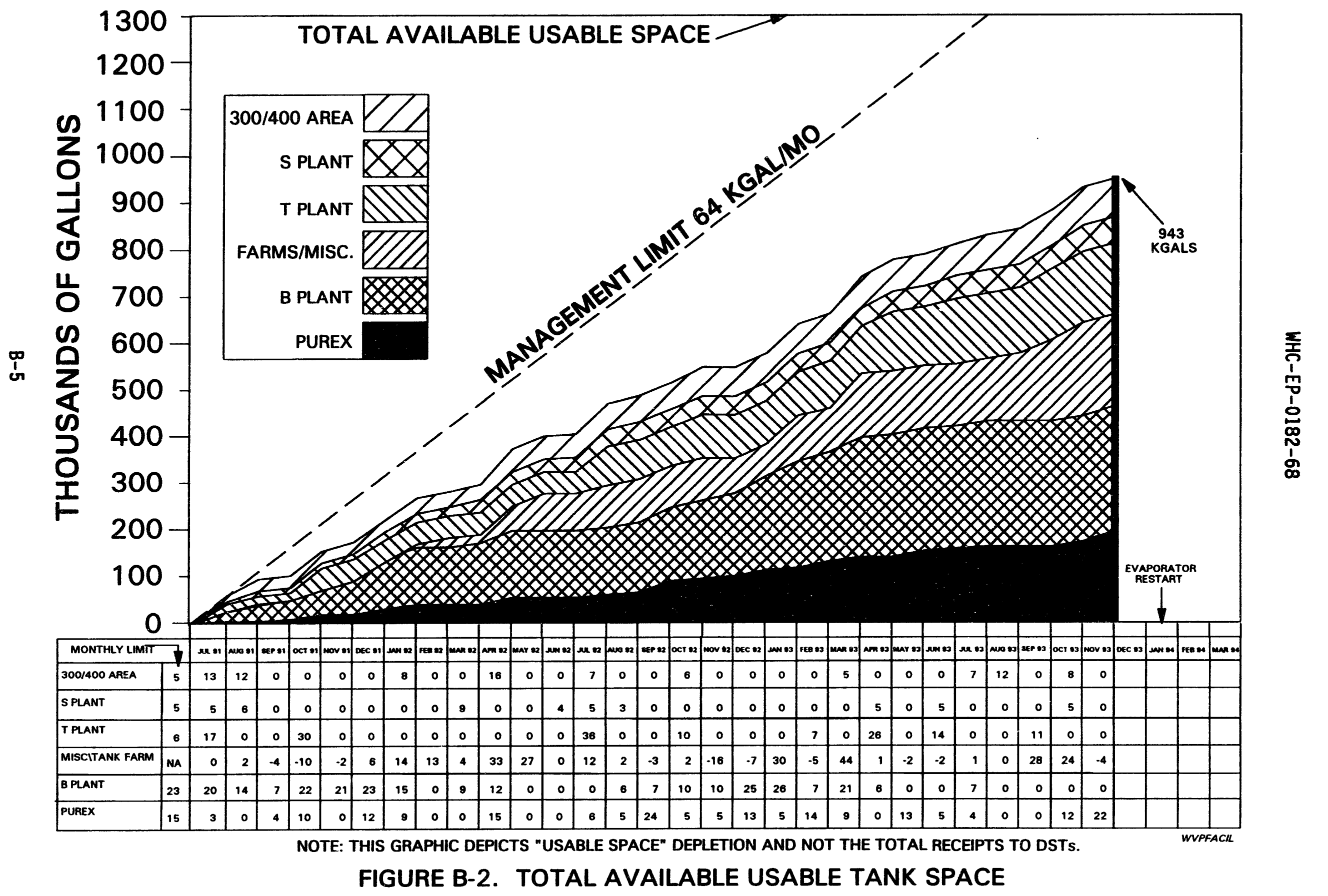




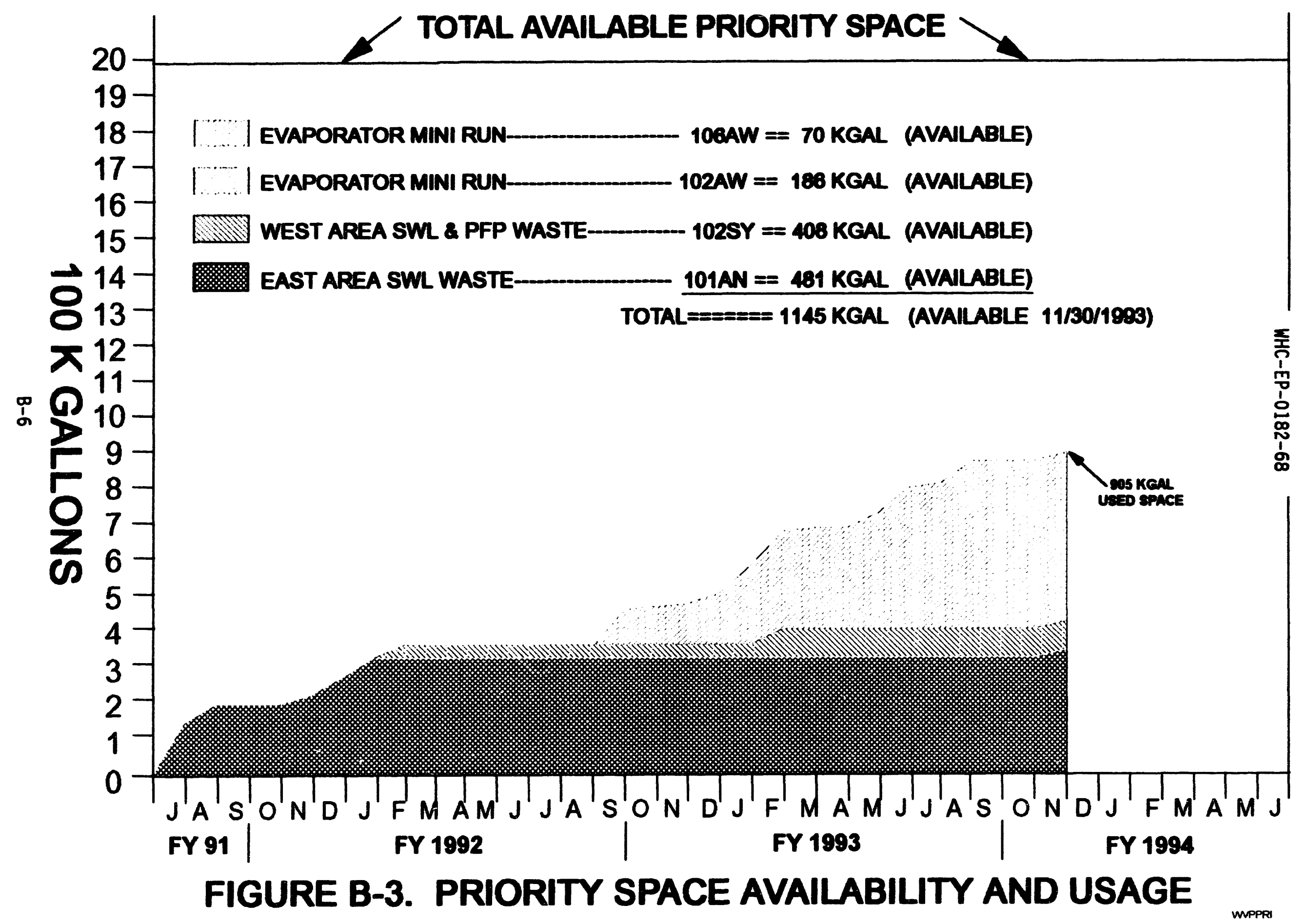




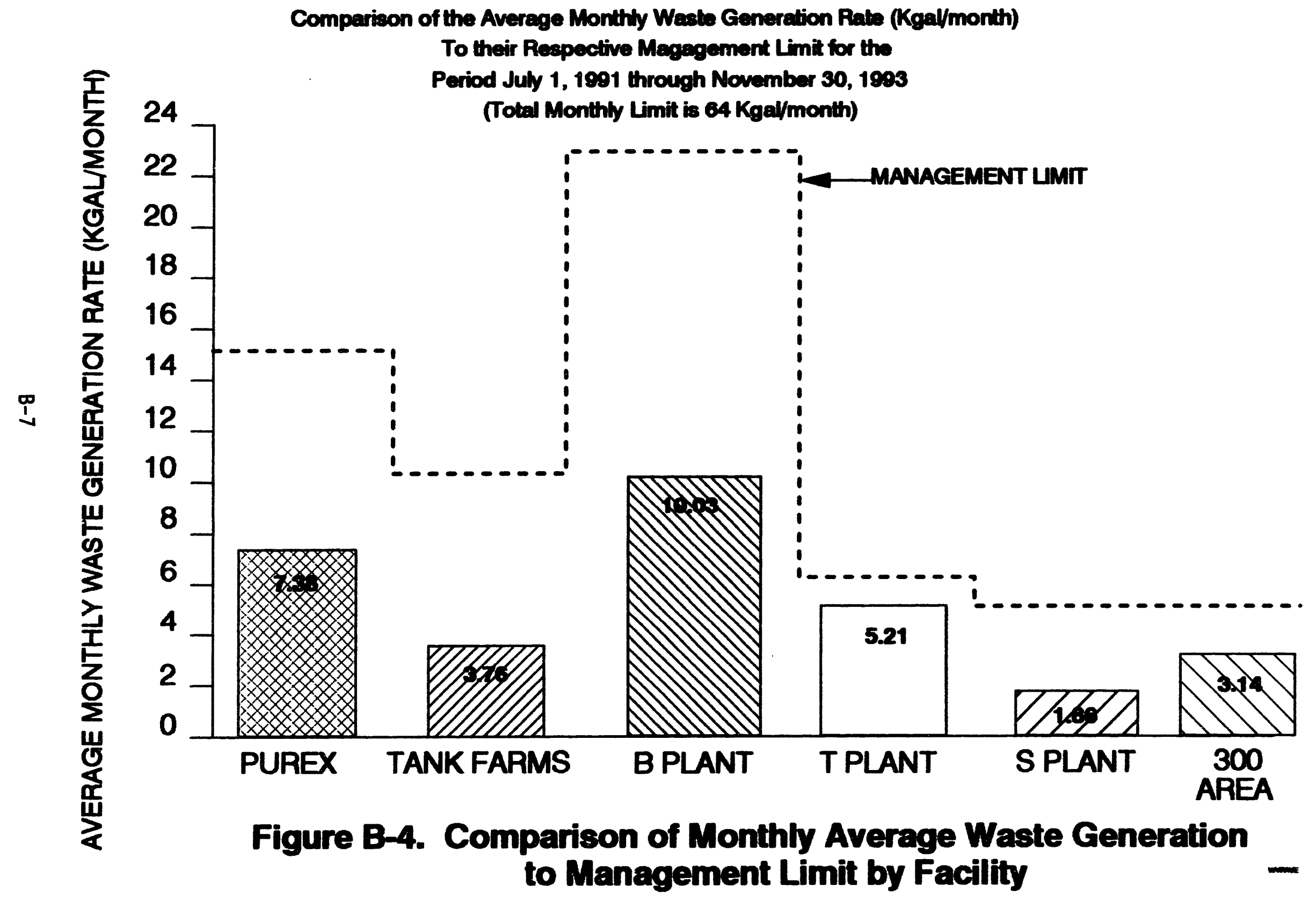




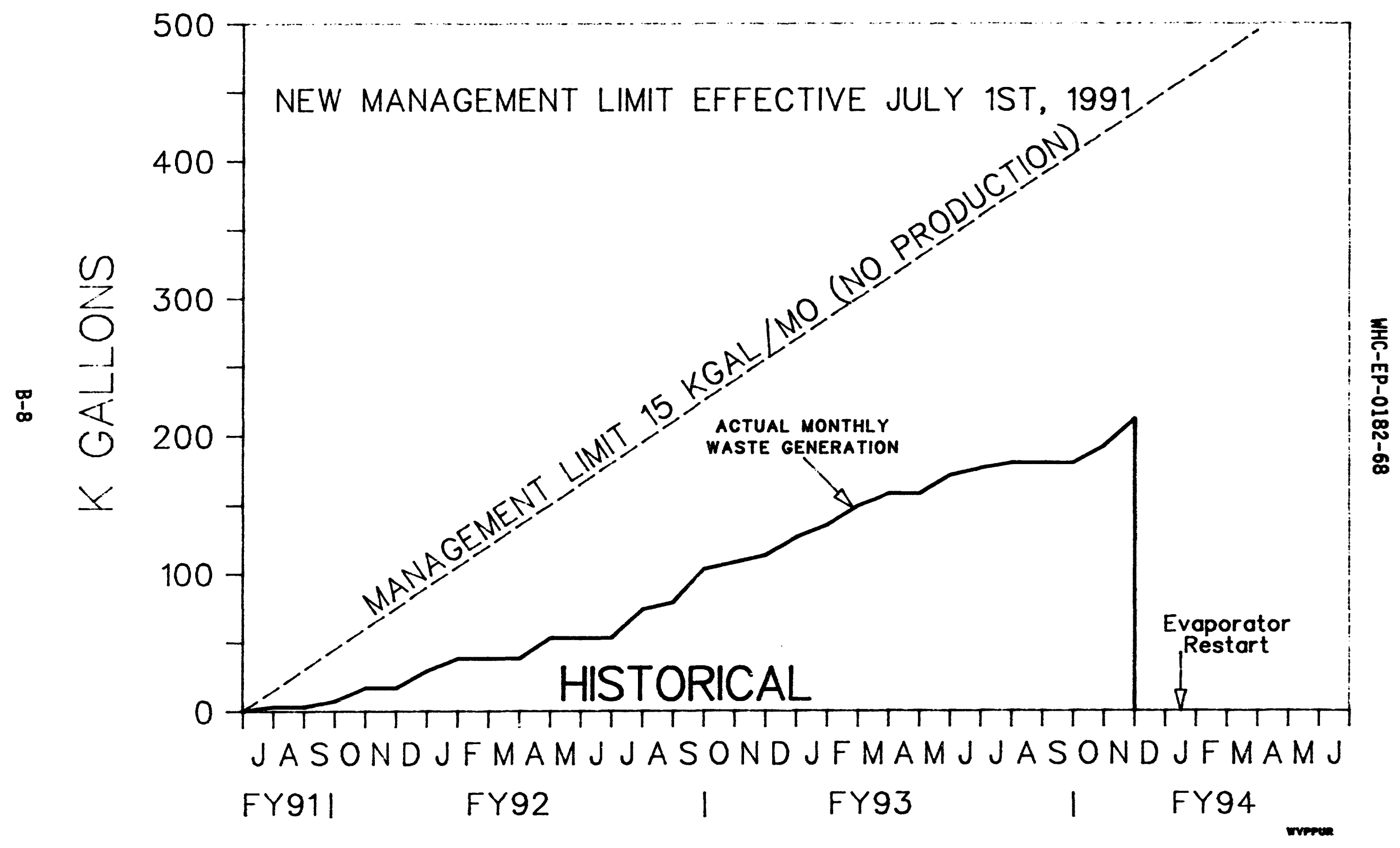

FIGURE B-5. PUREX MONTHLY WASTE GENERATIONS 


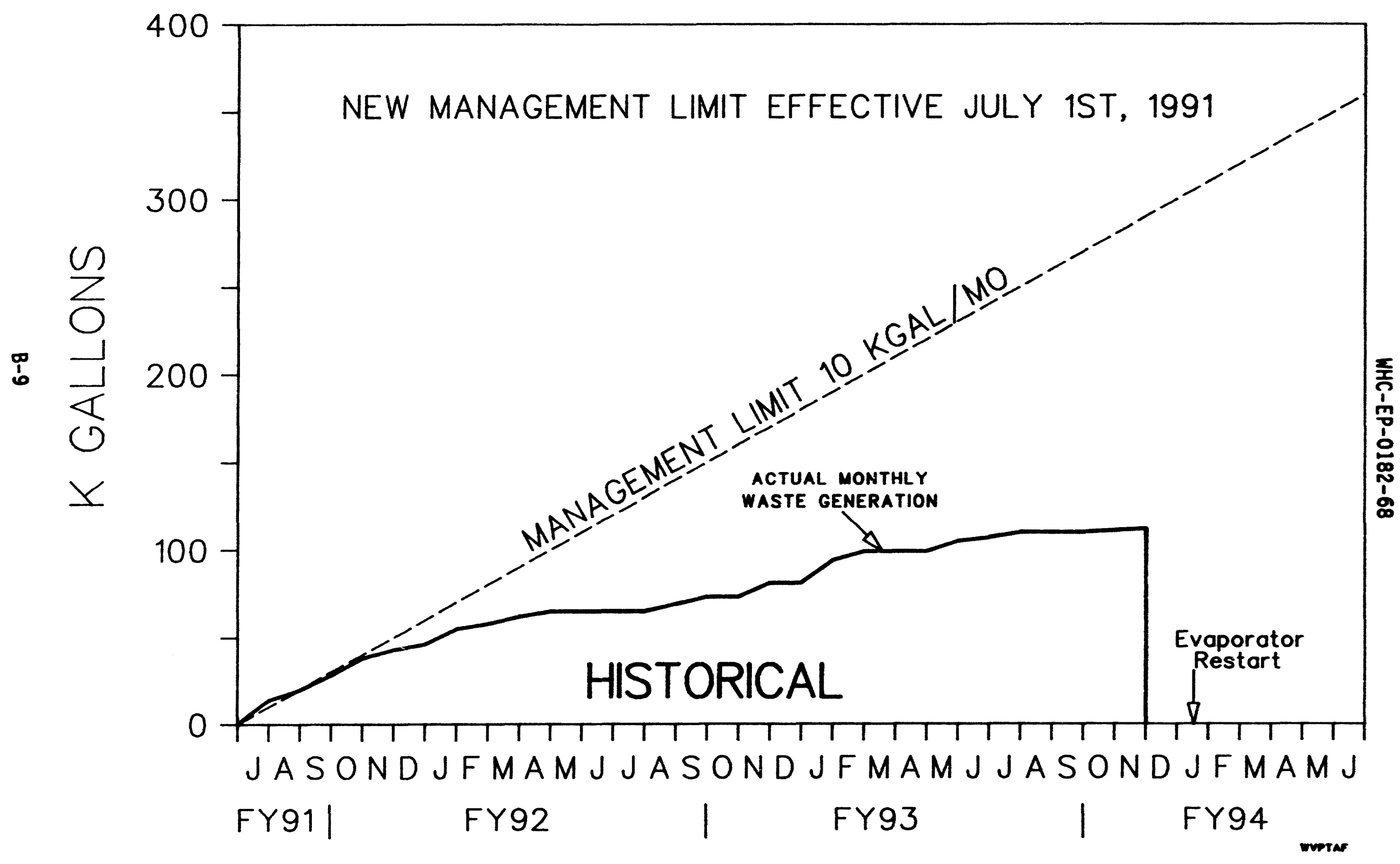

FIGURE B-6. TANK FARM MONTHLY WASTE GENERATIONS 


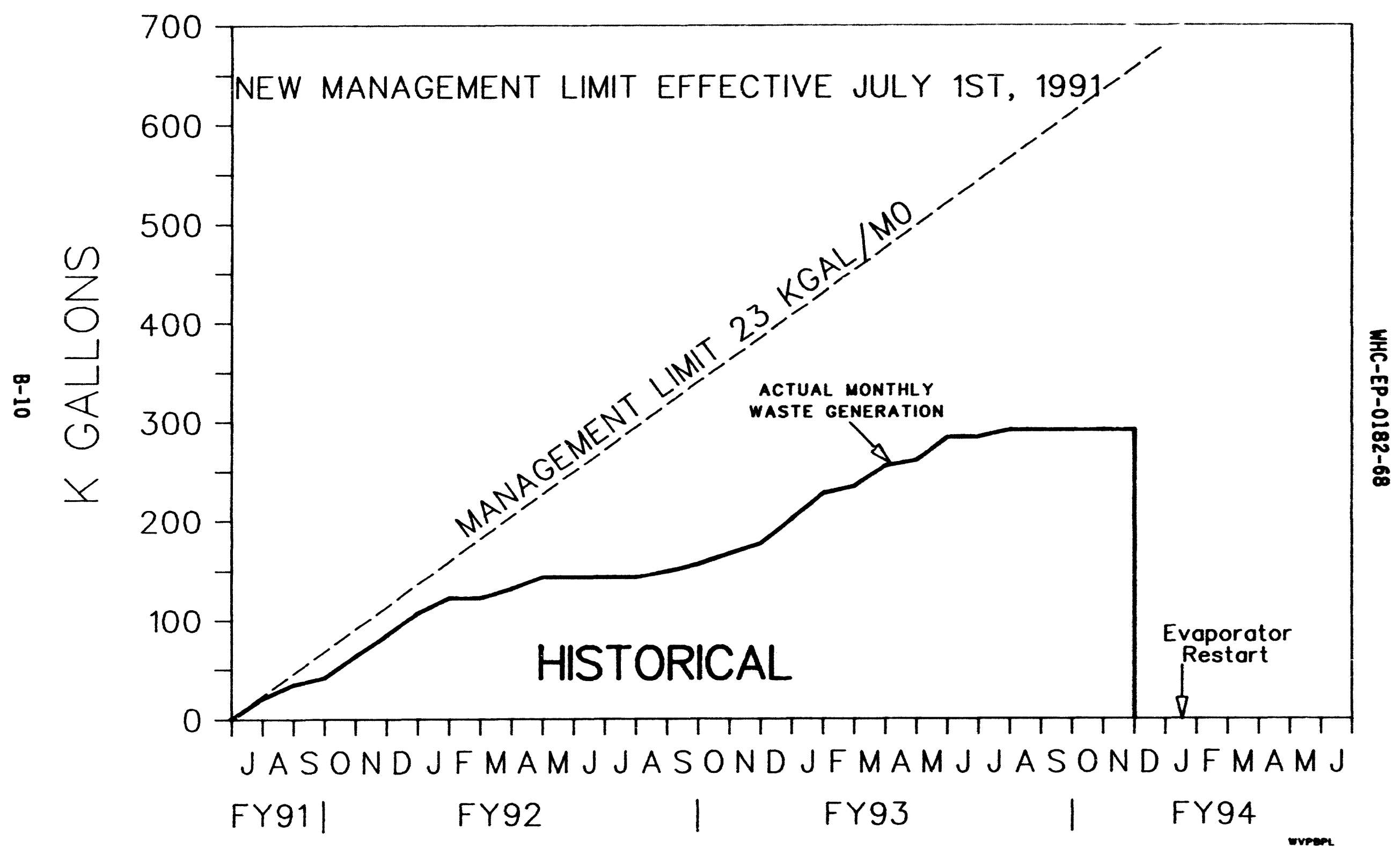

FIGURE B-7. B PLANT MONTHLY WASTE GENERATIONS 


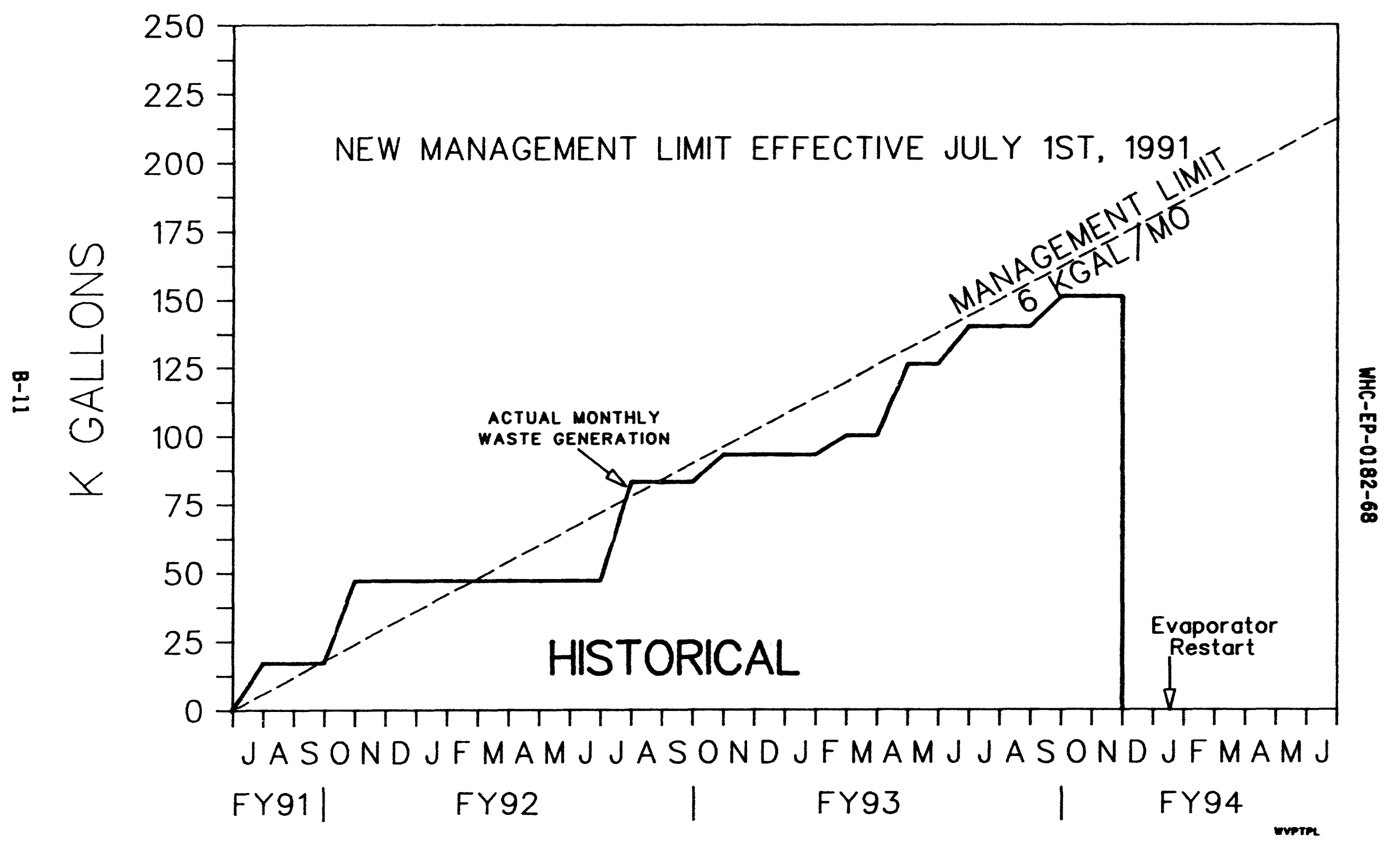

FIGURE B-8. T PLANT MONTHLY WASTE GENERATIONS 


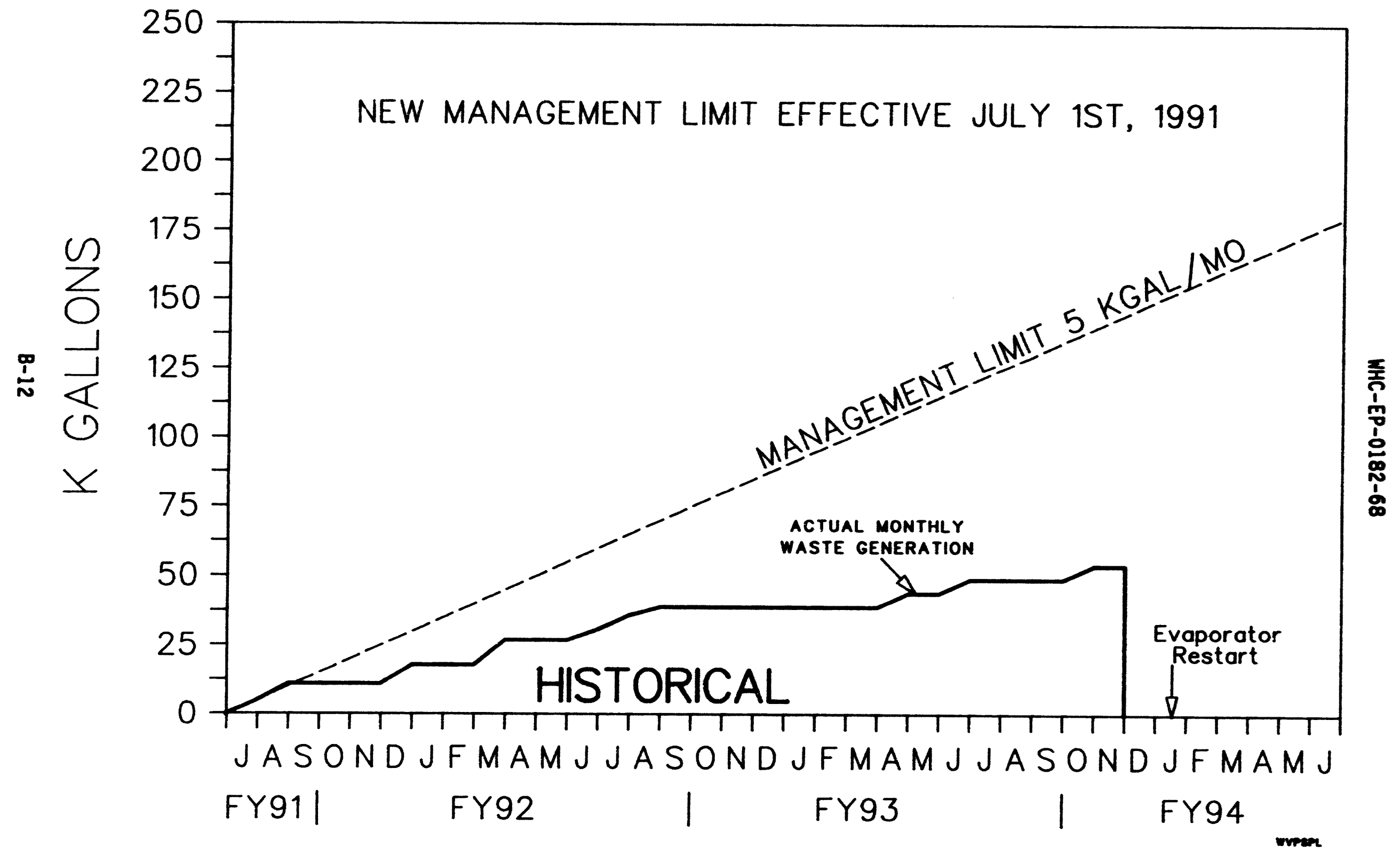

FIGURE B-9. S PLANT MONTHLY WASTE GENERATIONS 


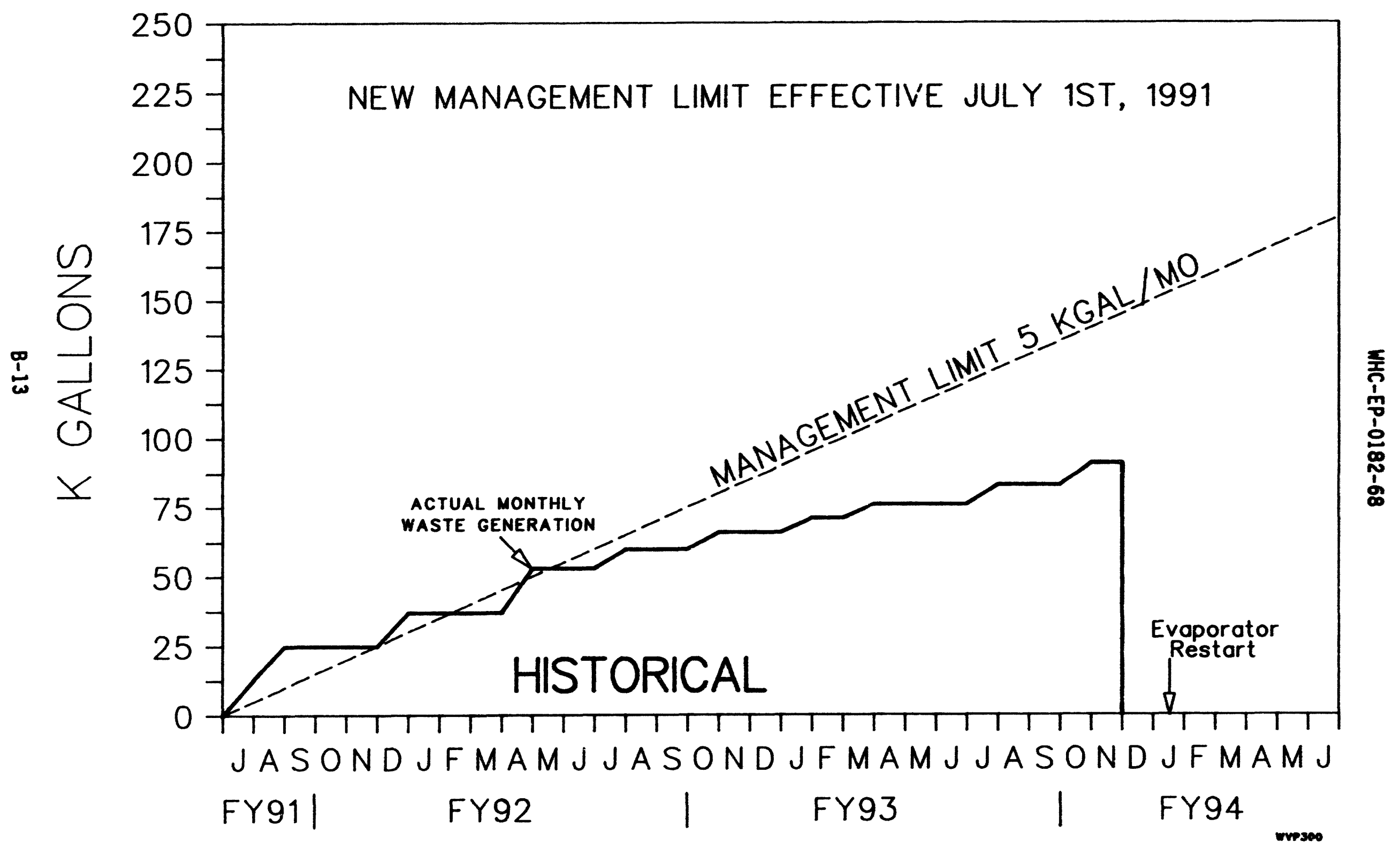

FIGURE B-10. 300 AREA MONTHLY WASTE GENERATIONS 
Table B-2. Double Shell Tank Waste Inventory for November 30, 1993

(page 1 of 2)

\begin{tabular}{|c|c|c|c|c|}
\hline$\frac{1 \text { Lants }}{101 A W=}$ & $\frac{\text { Wh-tincily }}{1141}$ & $\frac{910}{84}$ & $\frac{\text { inils }}{\text { DSSF }}$ & $\frac{2-1}{-1}$ \\
\hline $102 A W=$ & 954 & 3 & DN & 186 \\
\hline 10sAW= & 648 & 487 & PD/ON & 492 \\
\hline $104 A W=$ & 1123 & 267 & DN & 17 \\
\hline $105 A W=$ & 1037 & 388 & PD/DN & 108 \\
\hline $108 A W=$ & 1070 & 211 & DN & 70 \\
\hline $101 \mathrm{AY}=$ & 894 & 83 & DC & 86 \\
\hline $102 A Y=$ & 935 & 32 & DN & 45 \\
\hline $101 \mathrm{AZ}=$ & 940 & 35 & NCAW & 40 \\
\hline $102 A Z=$ & 945 & 95 & NCAW & 35 \\
\hline $101 \mathrm{AN}=$ & 659 & 0 & DN & 481 \\
\hline $102 A N=$ & 1097 & 89 & CC & 43 \\
\hline $103 A N=$ & 954 & 373 & DSS & 186 \\
\hline $104 \mathrm{AN}=$ & 1057 & 284 & DSSF & 83 \\
\hline $10 . A N=$ & 1129 & 0 & DSSF & 11 \\
\hline 1OSAN= & 21 & 17 & $\mathbf{C P}$ & 1119 \\
\hline $107 \mathrm{AN}=$ & 1066 & 134 & CC & 74 \\
\hline $101 S Y=$ & 1101 & 560 & $C C$ & 39 \\
\hline $1028 Y=$ & 732 & 133 & PT/ON & 408 \\
\hline $10 \operatorname{se} Y=$ & 743 & 4 & CC & 397 \\
\hline $101 \mathrm{AP}=$ & 1061 & 0 & DN & 79 \\
\hline $102 A P=$ & 1104 & 0 & $C P$ & 36 \\
\hline $10 S A P=$ & 1132 & 0 & DN & 8 \\
\hline $104 \mathrm{AP}=$ & 18 & 0 & DN & 1122 \\
\hline $105 A P=$ & 821 & 0 & DSSF & 319 \\
\hline $108 A P=$ & 1128 & 0 & DN & 12 \\
\hline 107AP $=$ & 1113 & 0 & DN & 27 \\
\hline 108AP= & 902 & 0 & DN & 238 \\
\hline TOTAL= & 2562 & & TOTAL & 5768 \\
\hline
\end{tabular}

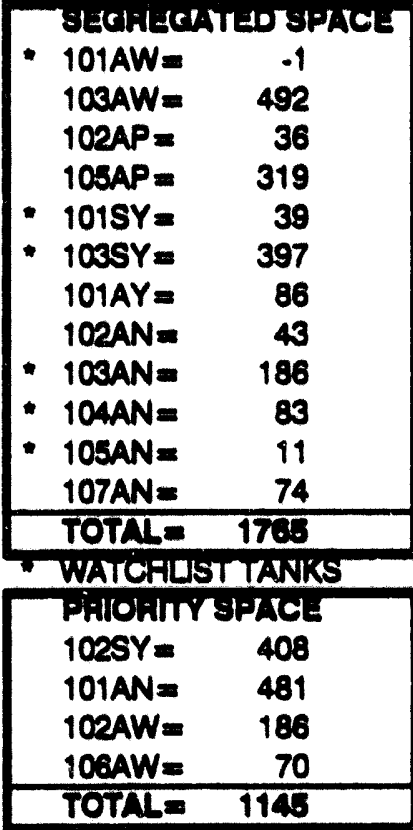

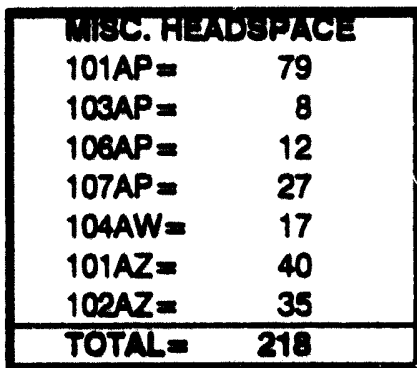

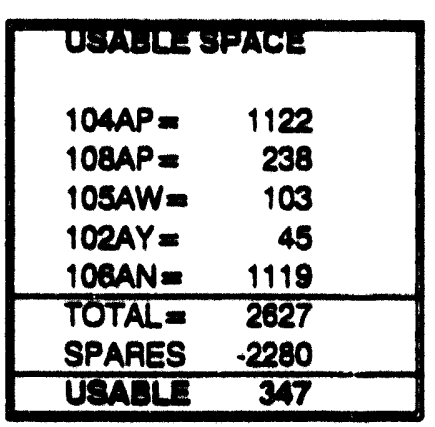

TOTALSFIACE TAVAICALLENON-AGING 27360 ACING $=3920$ TOTAL $=3120$

\begin{tabular}{l} 
TOTALINVGNIOAY \\
10/93 TOTAL 25519 \\
$11 / 93$ TOTAL 25525 \\
\hline MGNSAE
\end{tabular}

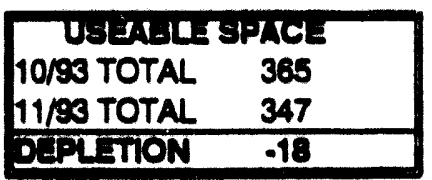

\begin{tabular}{|c|c|}
\hline \multicolumn{2}{|c|}{ Pillolitry SOLLE } \\
\hline $\begin{array}{l}\text { 10/93 TOTAL } \\
11 / 93 \text { TOTAL }\end{array}$ & $\begin{array}{l}1175 \\
1145\end{array}$ \\
\hline MORISE & \\
\hline
\end{tabular}

Inventory Calculation by Waste Type:

\begin{tabular}{|c|c|c|}
\hline $\begin{array}{l}\text { Col } \\
102 A N= \\
107 A N= \\
101 S Y= \\
103 S Y= \\
101 A Y=\end{array}$ & $\begin{array}{r}1097 \\
1068 \\
1101 \\
743 \\
894\end{array}$ & $\begin{array}{l}\text { (CC) } \\
\text { (CC) } \\
\text { (CC \& DSS) } \\
\text { (CC, DSS \& SWL) } \\
\text { (DC) }\end{array}$ \\
\hline
\end{tabular}

\begin{tabular}{|lll|}
\hline & NeliW & \\
103AW $=$ & 161 SOUDS $=$ & 487 \\
TOSAW $=$ & 649 SOUDS $=$ & 388 \\
\hline TOTALE & 810 TOTAL= & 875 \\
\hline
\end{tabular}

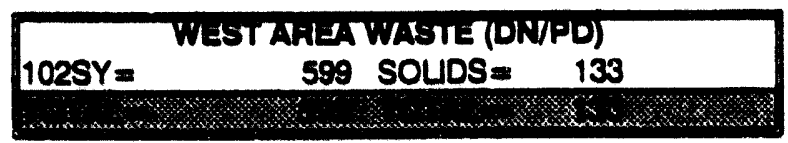

\begin{tabular}{|cc|}
\hline CONC. PHOSHFHATET(CH) \\
$106 A N=$ & 21 \\
$102 A P=$ & 1104 \\
&
\end{tabular}

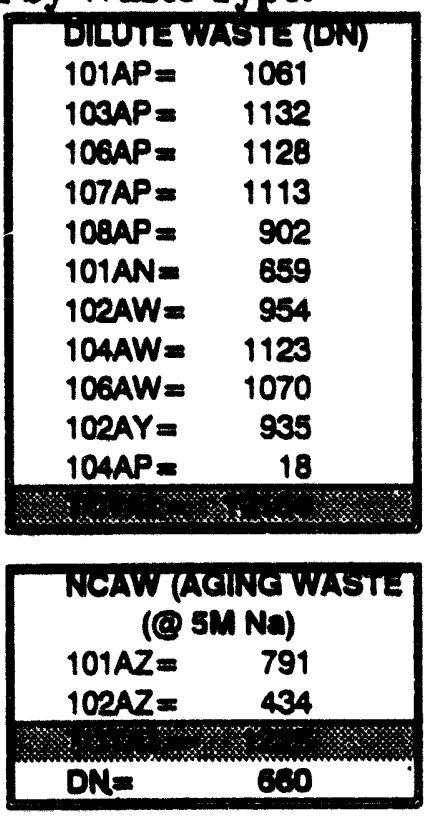

NOTE: All Values are in Kilogallons. 
Table B-2. Double Shell Tank Waste Inventory for November 30, $1993 \quad$ (page 2 of 2)

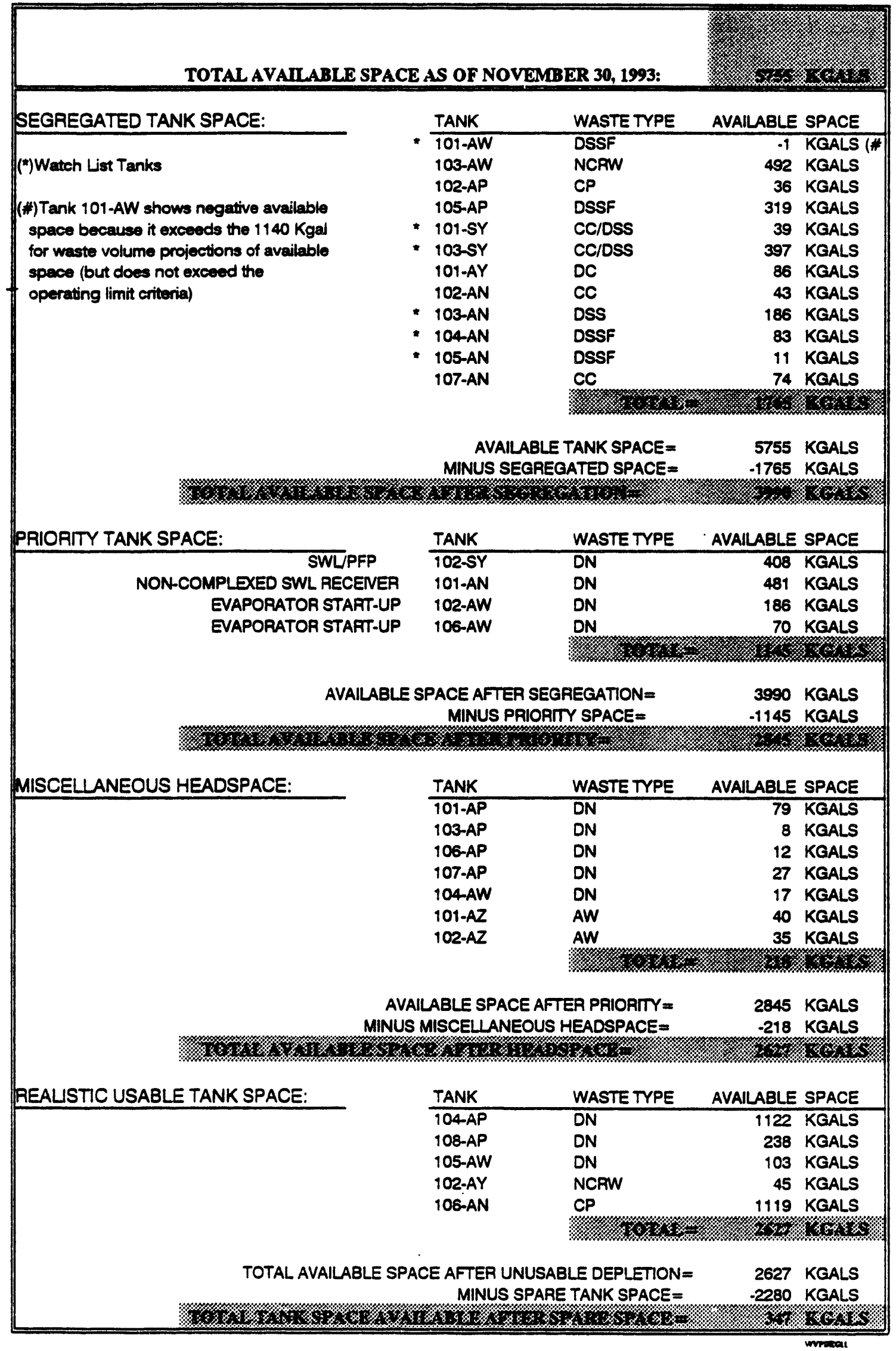


WHC-EP-0182-68

This page intentionally left blank 
WHC-EP-0182-68

\section{APPENDIX C}

TANK AND EQUIPMENT CODE AND STATUS DEFINITIONS 
WHC-EP-0182-68

This page intentionally left blank 


\section{TANK AND EQUIPMENT CODE/STATUS DEFINITIONS \\ November 1993}

\section{TANK STATUS CODES}

\section{WASTE TYPE}

$\begin{array}{ll}\text { AGING } & \text { Aging Waste (Neutralized Current Acid Waste [NCAW]) } \\ \text { CC } & \text { Complexant Concertrate Waste } \\ \text { CP } & \text { Concentrated Phosphate Waste } \\ \text { DC } & \text { Dilute Complexed Waste } \\ \text { DN } & \text { Dilute Non-Complexed Waste } \\ \text { DSS } & \text { Double-Shell Slurry } \\ \text { DSSF } & \text { Double-Shell Slurry Feed } \\ \text { NCPLX } & \text { Non-Complexed Waste } \\ \text { PD/PN } & \text { Plutonium-Uranium Extraction (PUREX) Neutralized Cladding } \\ & \text { Removal Waste (NCRW) transuranic Waste (TRU) } \\ \text { PT } & \text { Plutonium Finishing Plant (PFP) TRU Solids }\end{array}$

TANK USE (DOUBLE-SHELL TANKS ONLY)

CWHT Concentrated Waste Holding Tank

DRCVR Dilute Receiver Tank

EVFD Evaporate Feed Tank

GRTFD Grout Feed Tank

SRCVR STurry Receiver Tank

\section{SOLID AND LIOUID VOLUME DETERMINATION METHODS}

F Food Instrument Company (FIC) Automatic Surface Level Gauge

$M \quad$ Manual Tape Surface Level Gauge

$P \quad$ Photo Evaluation

S Sludge Level Measurement Device

\section{DEFINITIONS}

\section{WASTE TANKS - GENERAL}

Waste Tank Safety Issue

Watch List Tank
A potentially unsafe condition in the handling of waste material in underground storage tanks that requires corrective action to reduce or eliminate the unsafe condition.

An underground storage tank containing waste that requires special safety precautions because it may have a serious potential for release of high level radioactive waste because of uncontrolled increases in temperature or pressure. Special restrictions have been placed on these tanks by "Safety Measures for Waste Tanks at Hanford Nuclear Reservation," Section 3137 of the National Defense Authorization Act for Fiscal Year 1991, November 5, 1990, Public Law 101-510, (also known as the Wyden Amendment). 
WASTE TYPES

Aging Waste (AGING)

Concentrated Complexant (CC)

Concentrated Phosphate Waste (CP)

Dilute Complexed Waste (DC)
High level, first cycle solvent extraction waste from the PUREX plant (NCAW)

Concentrated product from the evaporation of dilute complexed waste.

Waste originating from the decontamination of the $\mathrm{N}$ Reactor in the $100 \mathrm{~N}$ Area. Concentration of this waste produces concentrated phosphate waste.

Characterized by a high content of organic carbon including organic complexants:

ethylenediaminetetra-acetic acid (EDTA), citric acid, and hydroxyethyl-ethylenediaminetriacetic acid (HEDTA), being the major complexants used. Main sources of DC waste in the DST system are saltwell liquid inventory (from SSTs).

Dilute Non-Complexed

Waste (DN)

Double-Shell

S1urry (DSS)

Double-Shel1 Slurry Feed (DSSF)

Non-complexed

(NCPLX)

PUREX Decladding (PD/PN)

PFP TRU Solids (PT)

Drainable Interstitial Liquid (DIL)
Low activity liquid waste originating from $T$ and S Plants, the 300 and 400 Areas, PUREX facility (decladding supernatant and miscellaneous wastes), $100 \mathrm{~N}$ Area (sulfate waste), B Plant, saltwells, and PFP (supernate).

Waste that exceeds the sodium aluminate saturation boundary in the evaporator without exceeding receiver tank composition limits. For reporting purposes, DSS is considered a solid.

Waste concentrated just before reaching the sodium aluminate saturation boundary (of $6.5 \mathrm{~mol}$ ar hydroxide) in the evaporator without exceeding receiver tank composition limits. This form is not as concentrated as DSS.

General waste term applied to all Hanford Site liquors not identified as complexed.

PUREX Neutralized Cladding Removal Waste (NCRW) is the solids portion of the PUREX plant neutralized cladding removal waste stream; received in Tank Farms as a slurry. NCRW solids are classified as transuranic (TRU) waste.

TRU solids fraction from PFP Plant operations.

Interstitial liquid that is not held in place by capillary forces, and will therefore migrate or move by gravity. 
Supernate

Ferrocyanide

\section{MASTE STATUS}

In-Service Tank

Out-of-Service Tank
The liquid above the solids in waste storage tanks.

A compound of iron and cyanide commonly expressed as FeCN. The actual formula for the ferrocyanide anion is $\left[\mathrm{Fe}(\mathrm{CN})_{6}\right]^{-4}$.

The waste classification of a tank being used, or planned for use, for the storage of liquid (in excess of a minimum supernatant liquid heel) in conjunction with production and/or waste processing.

A tank which does not meet the definition of an inservice tank. Before September 1988, these tanks were defined as inactive in this report. [Note: All single-shell tanks (SST) are out of service.]

\section{STABILIZATION (Single-Shell Tanks only)}

Interim

Stabilized

(IS)
A tank which contains less than 50,000 gal of drainable interstitial liquid and less than 5,000 gal of supernatant liquid. If the tank was jet pumped to achieve interim stabilization, then the jet pump flow must also have been at or below $0.05 \mathrm{gpm}$ before interim stabilization criteria is met.

\section{INTRUSION PREVENTION (ISOLATION) Single-Shell Tanks only}

Partially

Interim Isolated

(PI)

Interim Isolated (II)

Intrusion

Prevention (IP)
The administrative designation reflecting the completion of the physical effort required for Interim Isolation except for isolation of risers and piping that is required for jet pumping or for other methods of stabilization.

The administrative designation reflecting the completion of the physical effort required to minimize the addition of 1 iquids into an inactive storage tank, process vault, sump, catch tank, or diversion box. In June 1993, Interim Isolation was replaced by Intrusion Prevention.

Intrusion Prevention is the administrative designation reflecting the completion of the physical effort required to minimize the addition of liquids into an inactive storage tank, process vault, sump, catch tank, or diversion box. Under no circumstances are electrical or instrumentation devices disconnected or disabled during the intrusion preventation process (with the exception of the electrical pump), in accordance with WHC-SDWM-SAR-006 REV 2, Single-Shell Tank I solation Safety Analysis Report, March 1986. 
IANK INTEGRITY

Sound

The integrity classification of a waste storage tank for which surveillance data indicate no loss of liquid attributed to a breach of integrity.

Assumed Leaker

The integrity classification of a waste storage tank for which surveillance data indicate a loss of liquid attributed to a breach of integrity.

Assumed Re-Leaker A condition that exists after a tank has been declared as an "assumed leaker" and then the surveillance data indicates a new loss of liquid attributed to a breach of integrity.

TANK INVESTIGATION

Intrusion

A term used to describe the infiltration of liquid into a waste tank.

\section{SURVEILLANCE INSTRUMENTATION}

Drywe11s

Drywells are vertical boreholes with 6-in. (internal diameter) carbon steel casings positioned radially around SSTs. Periodic monitoring is done by gamma radiation or neutron sensors to obtain scan profiles of radiation or moisture in the soil as a function of well depth, which could be indicative of tank leakage. These wells range between 50 and $250 \mathrm{ft}$ in depth, and are monitored between the range of 50 to $150 \mathrm{ft}$. The wells are sealed when not in use. They are called drywells because they do not penetrate to the water table and are therefore usually "dry." The drywell frequency monitoring schedule calls for 105 drywe1ls weekly, 91 biweekly, 41 monthly, 151 quarterly, and 371 annually.

Laterals Laterals are horizontal drywells positioned under single-shell waste storage tanks to detect radionuclides in the soil which could be indicative of tank leakage. These drywells are monitored by radiation detection probes. Laterals are 4-in. inside diameter steel pipes located 8 to $10 \mathrm{ft}$ below the tank's concrete base. There are three laterals per tank. Laterals are located only in $A$ and $S X$ farms.

Surface Levels The surface level measurements in all waste storage tanks are monitored by manual or automatic conductivity probes, and recorded and transmitted or inputted to the Computer Automated Surveillance System (CASS). 
Automatic FIC

Annulus

Liquid Observation Well (LOW)

Thermocouple (TC)
An automatic waste surface level measurement device is manufactured by the Food Instrument Company (FIC). The instrument consists of a conductivity electrode (plummet) connected to a calibrated steel tape, a steel tape reel housing and a controller that automatically raises and lowers the plummet to obtain a waste surface level reading. The controller can provide a digital display of the data and also transmit the reading to the CASS. Some tanks have gauges connected to CASS and others are read manualiy.

The annulus is the space between the inner and outer shells on DSTs. Drain channels in the insulating and/or supporting concrete carry any leakage to the annulus space where conductivity probes are installed. Alarms from the annunciators are received by CASS. Continuous Air Monitoring (CAM) alarms are also located in the annulus. The annulus conductivity probes and radiation detectors are the primary means of leak detection for all DSTs.

In-tank liquid observation wells are used for monitoring the interstitial liquid level (ILL) in single-shell waste storage tanks. The wells are constructed of fiberglass or TEFZEL*-reinforced epoxy-polyester resin, sized to extend to within 1 in. of the bottom of the tank steel 1iner. They are sealed at their bottom ends and have a nominal outside diameter of $3.5 \mathrm{in}$. Two probes are used to monitor changes in the ILL: gamma and neutron, which can indicate intrusions or leakage by ir.creases or decreases in the ILL. There are 58 LOWs ( 56 are in operation) installed in SSTs that contain or are capable of containing greater than 50,000 gal of drainable interstitial iquid, and in two DSTs only. The LOWs installed in two DSTs, (102-SY and 103-AW Tanks), are constructed of steel and are used for special surveillance purposes only.

A thermocouple is a thermoelectric device used to measure temperature. More than one thermocouple on a device (probe) is called a thermocouple tree. In DSTs there may be one or more thermocouple trees in risers in the primary tank. In addition, in DSTs only, there are thermocouple elements installed in the insulating concrete, the lower primary tank knuckle, the secondary tank concrete foundation, and in the outer structural concrete. These monitor temperature gradients within the concrete walls,

*TEFZEL, a trademark of E. I. du Pont de Nemours \& Company 
installed in a riser, or lowered down an existing bottom of the tank, and the domes. In SSTs, there may be one or more thermocouple trees installed directly in a tank, although some SSTs do not have any trees installed. A single thermocouple may be in ariser or LOW. There are also four thermocouple laterals beneath Tank 105-A in which temparature readings are taken in 34 thermocouples.

In-tank

Photography
In-tank photographs may be taken to aid in resolving in-tank measurement anomalies and determine tank integrity. Photographs help determine sludge and liquid levels by visual examination.

\section{INYENTORY AND STATUS BY TANK - COLUMN CALCULATIONS (SINGLE-SHELL TANKS)}

\section{COLUNM HEADING}

Total Waste

Solids Volume plus Supernatant liquid.

Supernatant Liquid

\section{Drainable Interstitial}

Total Jet

Pumped

Drainable

Liquid

Remaining

Pumpable

Liquid

Remaining

Sludge

Saltcake estimate the volume.
Drainable Liquid Remaining minus Drainable Interstitial. Supernate is usually derived by subtracting the solids level measurement from the liquid level measurement.

Drainable Liquid Remaining minus Supernate. Drainable Interstitial Liquid is calculated based on the saltcake and sludge volumes, using average porosity values or actual data for each tank, when available.

Cumulative total pumped 1979 to date.

Supernate plus Drainable Interstitial.

Drainable Liquid Remaining less undrainable heel volume.

Solids formed during sodium hydroxide additions to waste. sludge usually was in the form of suspended solids when the waste was originally received in the tank from the waste generator. In-tank photographs may be used to

Results from crystalization and precipitation after concentration of liquid waste, usually in an evaporator. If saltcake is layered over sludge, it is only possible to measure total solids volume. In-tank photographs may be used to estimate the saltcake volume. 
Solids Volume Indicates the latest update of any change in the solids Update volume.

Solids Update Indicates the source or basis of the latest solids Source - See volume update.

Footnote

Last Photo Date of latest in-tank photographs taken.

Date

Change Since Last Monthly Report

Indicates any change made since the previous month. Explanation for the change follows the Inventory and Status by Tank section. 


\section{WHC-EP-0182-68}

This page intentionally left blank 
WHC-EP-0182-68

\section{APPENDIX D}

TANK FARM CONFIGURATION, STATUS, AND FACILITY CHARTS 
WHC-EP-0182-68

This page intentionally left blank. 


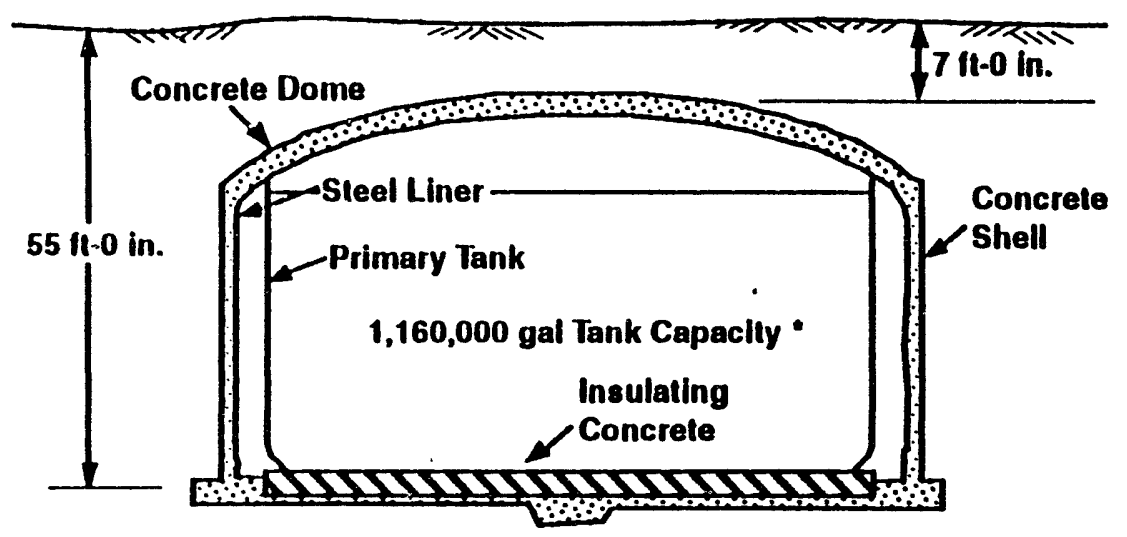

75 II Diameler Double-Shell Tank Tank Farms: AN, AP, AW, AY, AZ, SY

$\stackrel{0}{1}$

$$
\text { - AY and AZ Have a Tank Capacily }
$$
of $1,000,000 \mathrm{gal}$

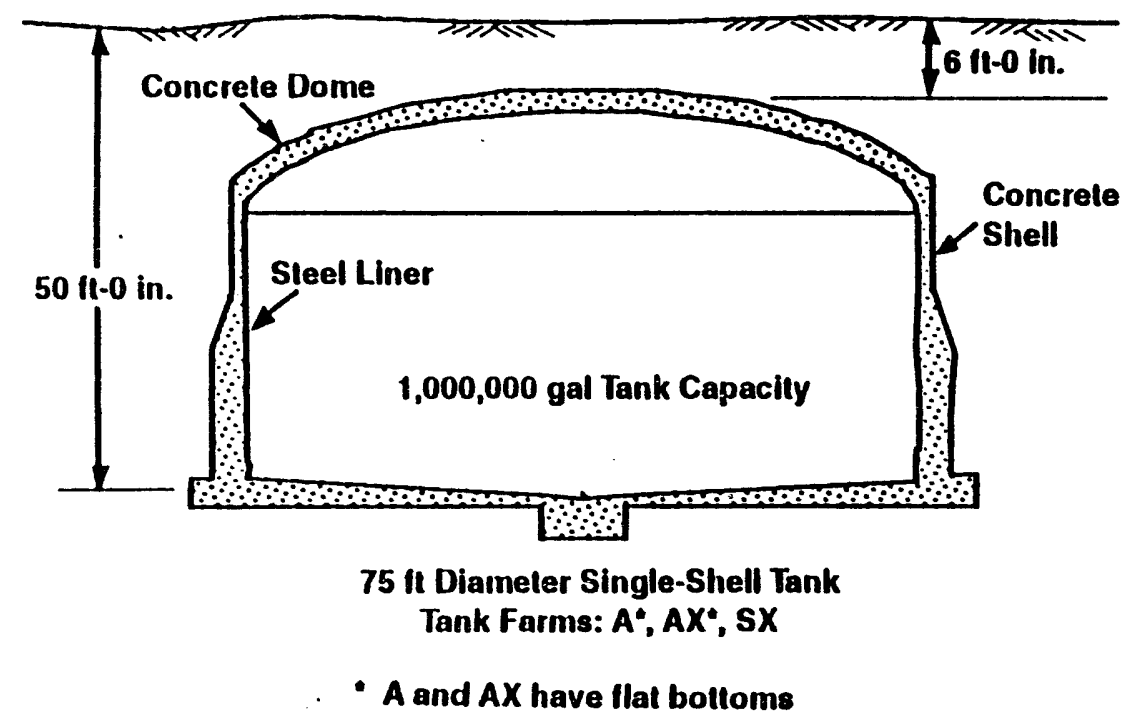

- $A$ and $A X$ have flat boltoms
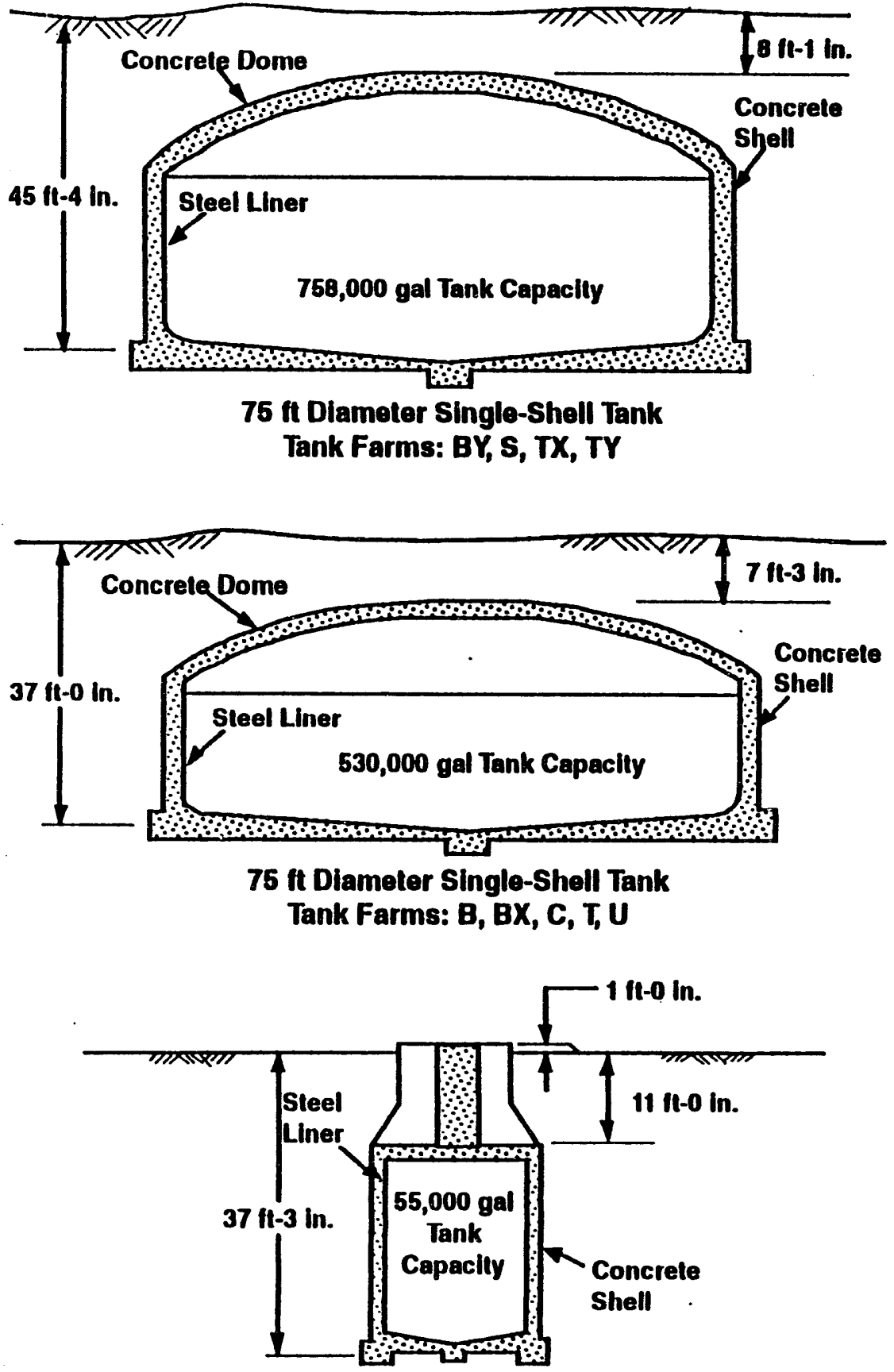

20 it Diameler Single-Shell Tank Tank Farms: B, C, T, U

Figure D-1. High-Level Waste Tank Configuration 


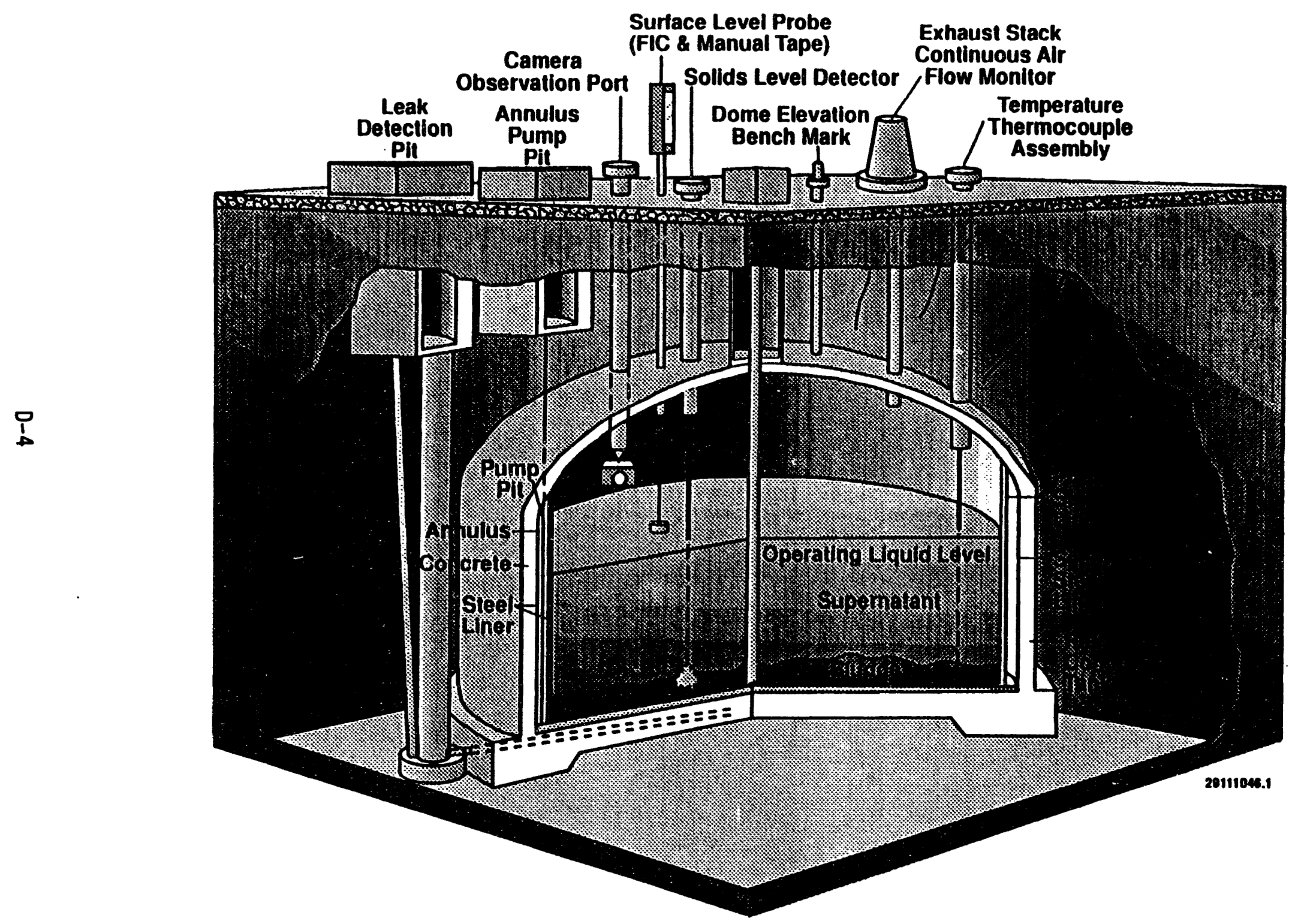

Figure D-2. Double-Shell Tank Instrumentation Configuration 


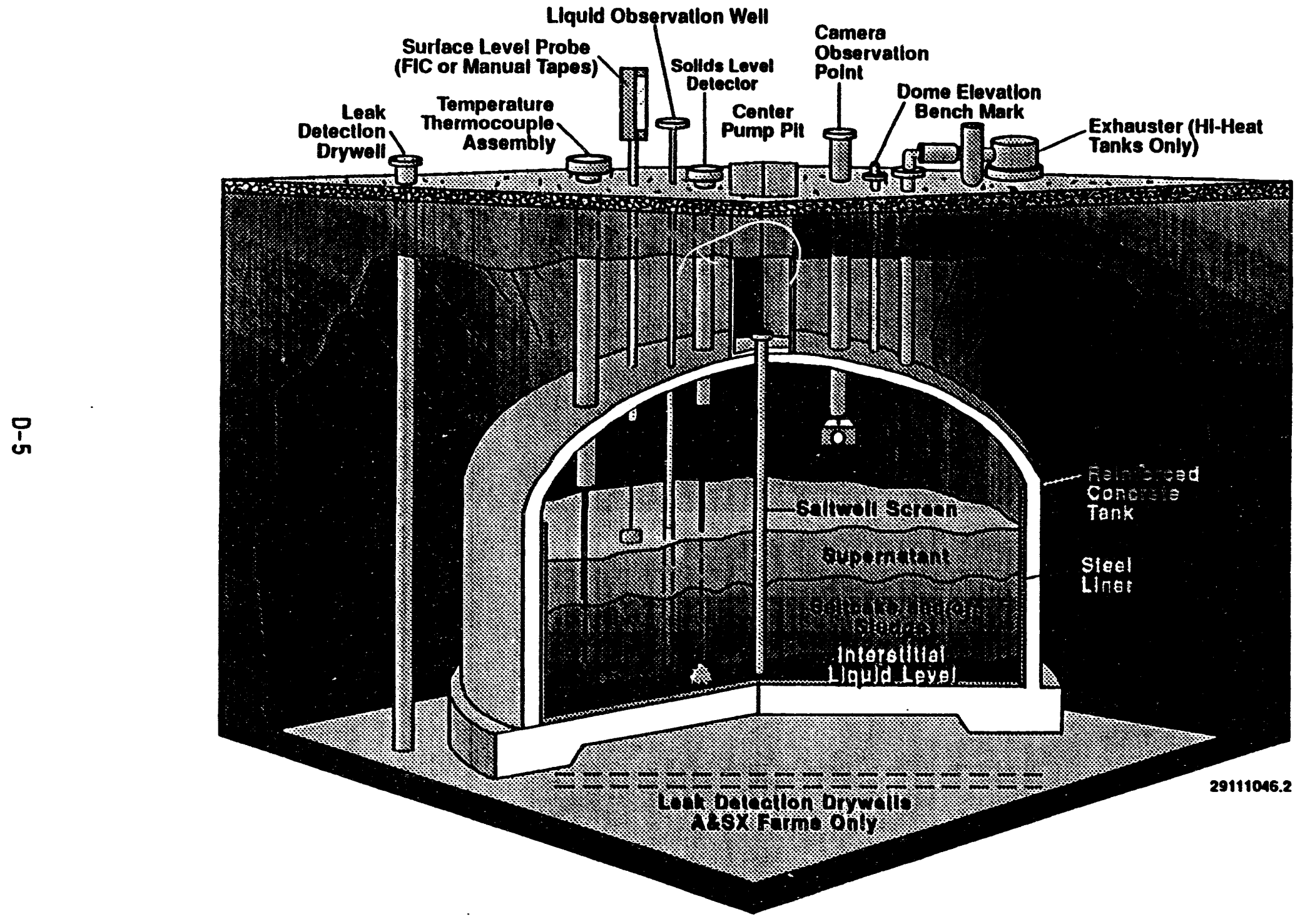

Figure D-3. Single-Shell Tank Instrumentation Configuration 
WHC-EP-0182-68

This page intentionally left blank 


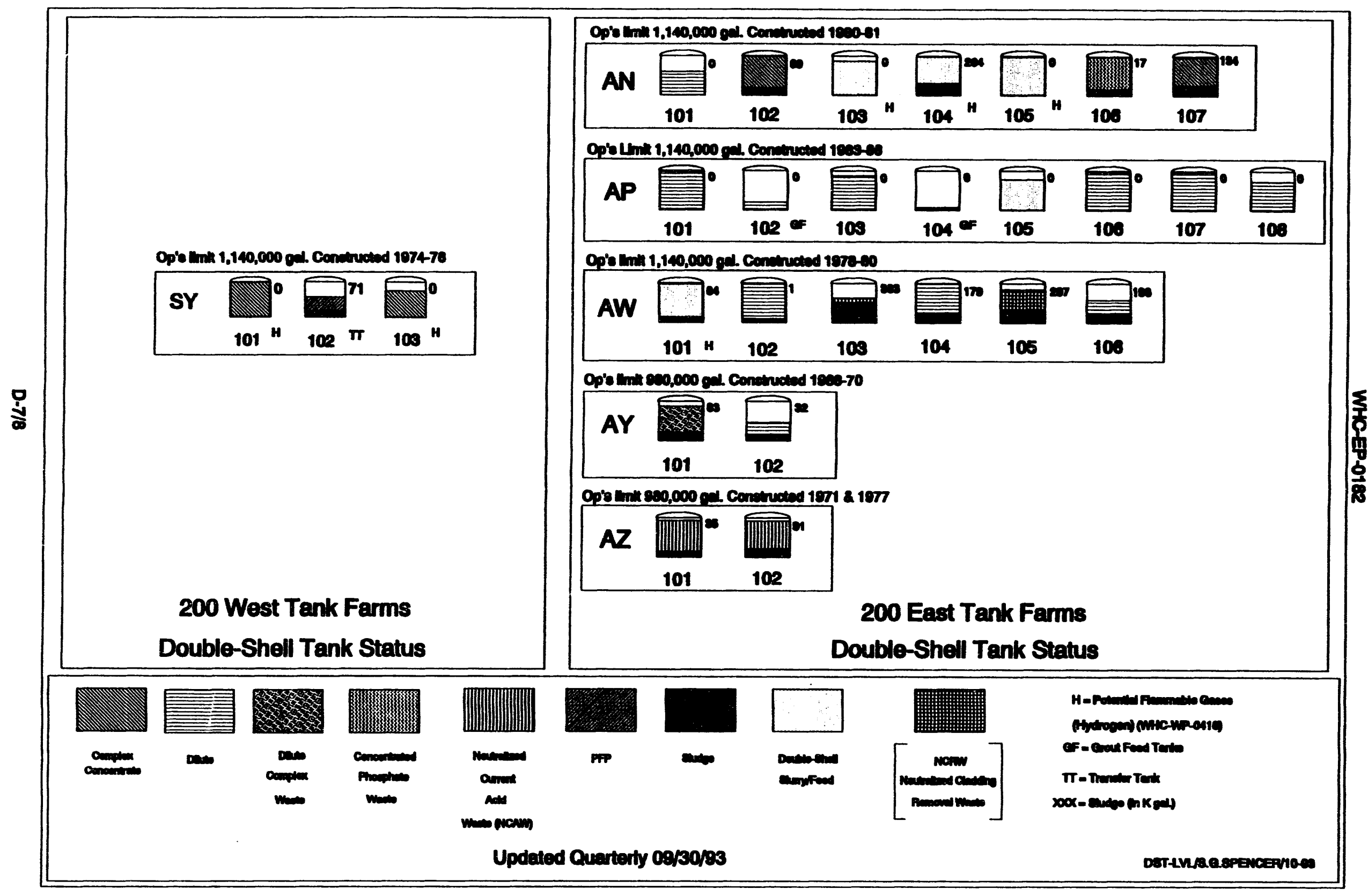

Figure D-4. Double-Shell Tonk Stetus 
1,000,000 gal tanks Contruetad 19545s

A

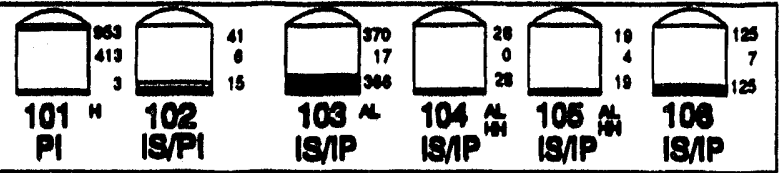

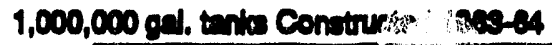

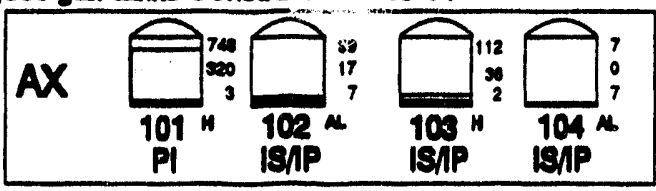

$500,000 \mathrm{gal}$ tanks Construetod $1949-44$

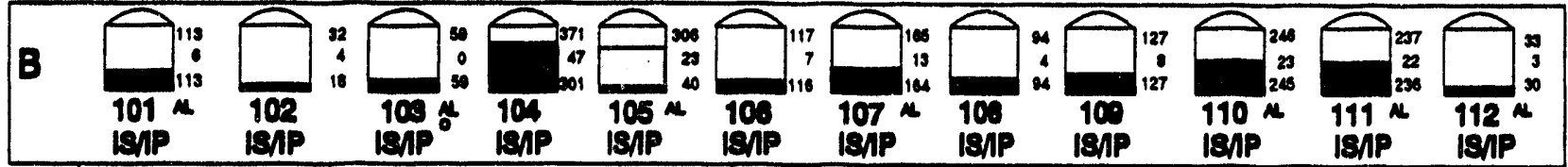

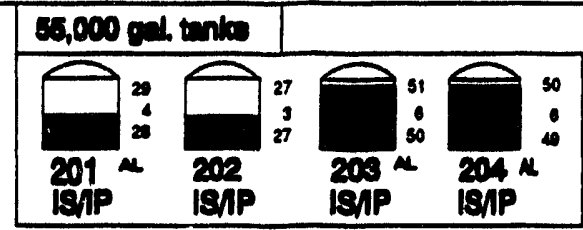

$600,000 \mathrm{ged}$. tank Conomutad 194047

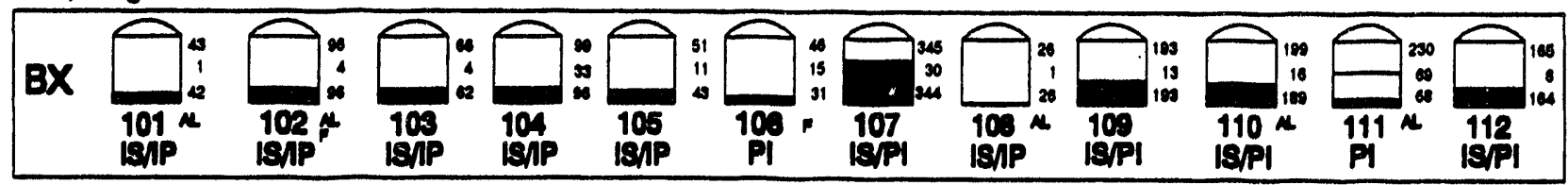

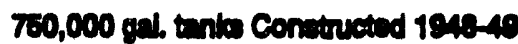

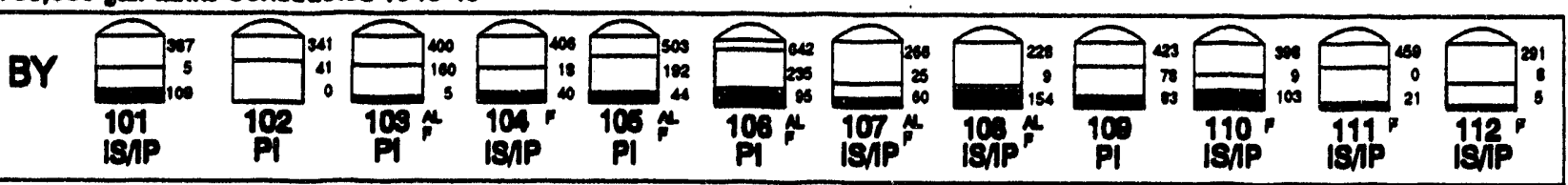

$800,000 \mathrm{gal}$ tanke Conetruated $1904-44$

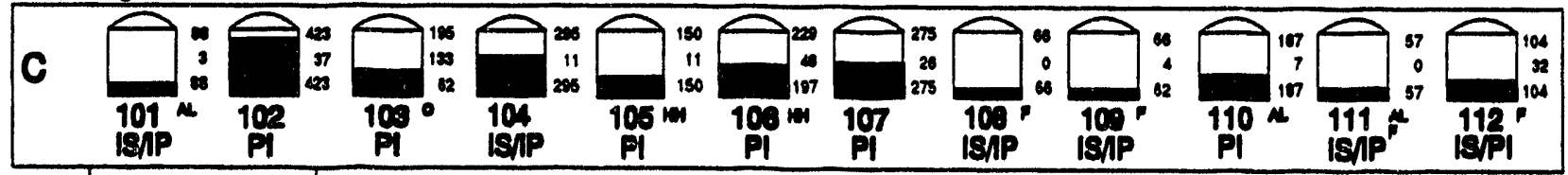

\begin{tabular}{|c|c|c|c|}
\hline \multicolumn{2}{|c|}{$85,000 \mathrm{gat}$ tants } & & \\
\hline & 2 & & \\
\hline $\begin{array}{l}201 \\
\text { ISNP }\end{array}$ & $\begin{array}{l}202^{\wedge} \\
181 P\end{array}$ & $\begin{array}{l}203^{\mu} \\
\text { ISAP }\end{array}$ & $\begin{array}{l}204 \\
\text { LSNP }\end{array}$ \\
\hline
\end{tabular}

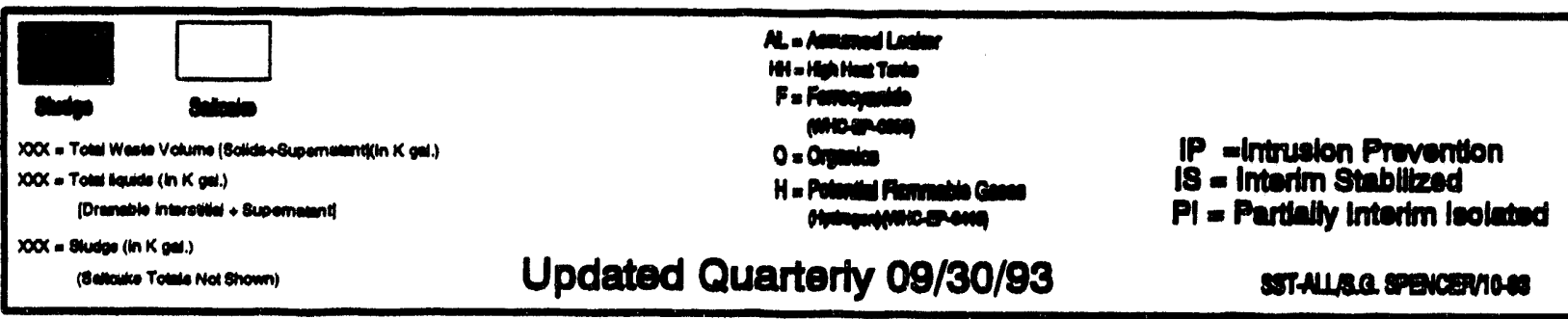

Figure D-5. OE Single-Shell Tank Status 
700,000 gal. tenke Condruebed 1000-81

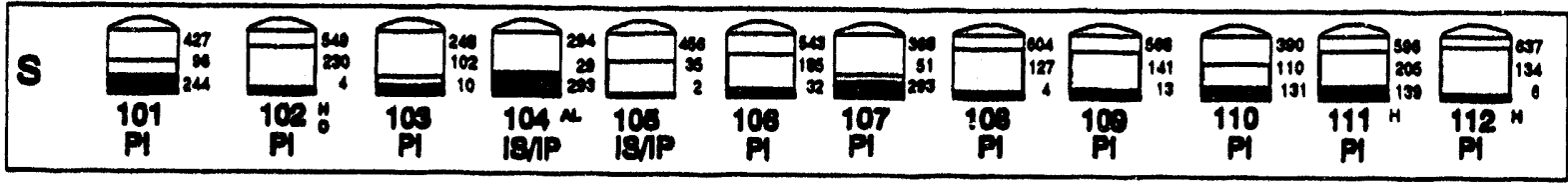

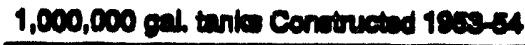

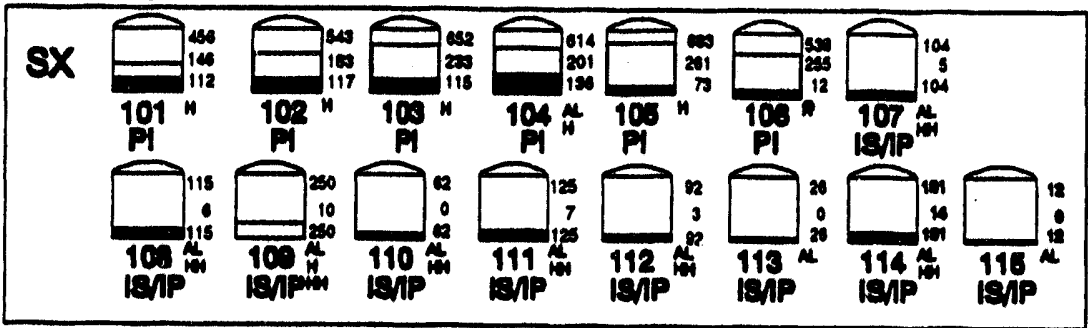

500,000 od. tonis Contrued 1940-44

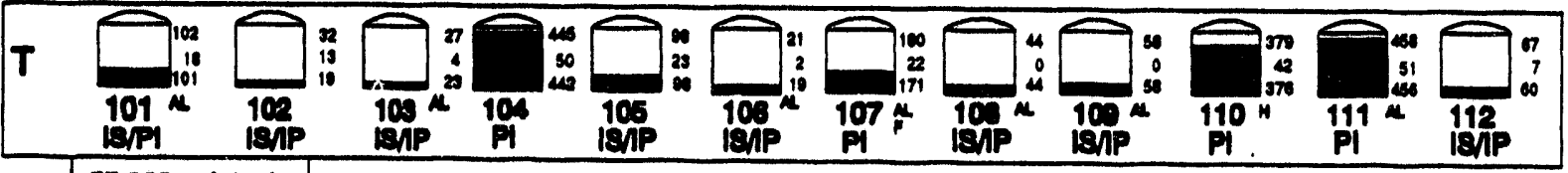

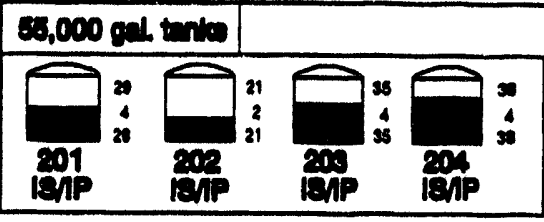

$700,000 \mathrm{gm}$. tanke Conmtrucind 1947 40

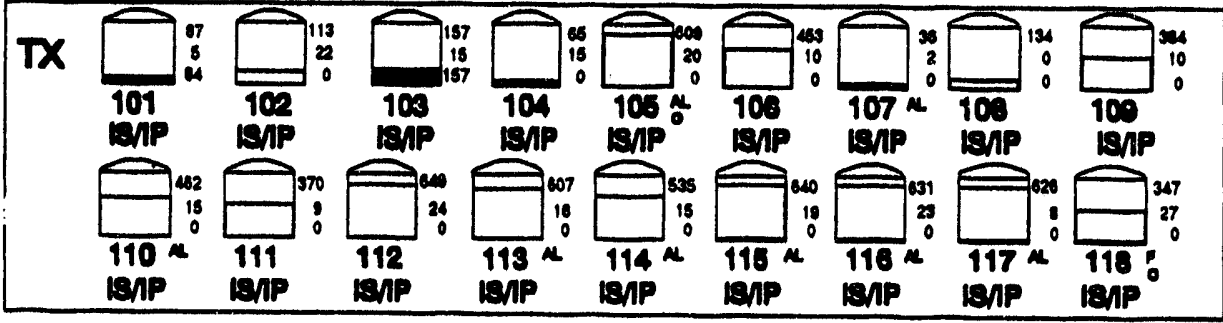

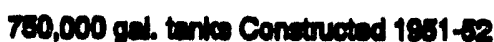

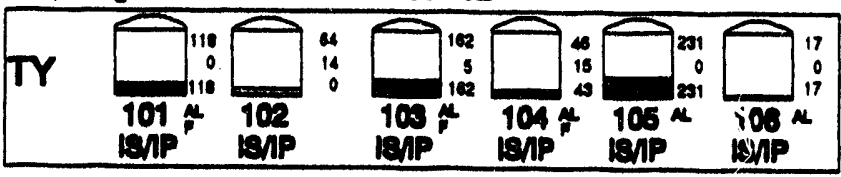

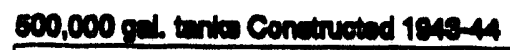

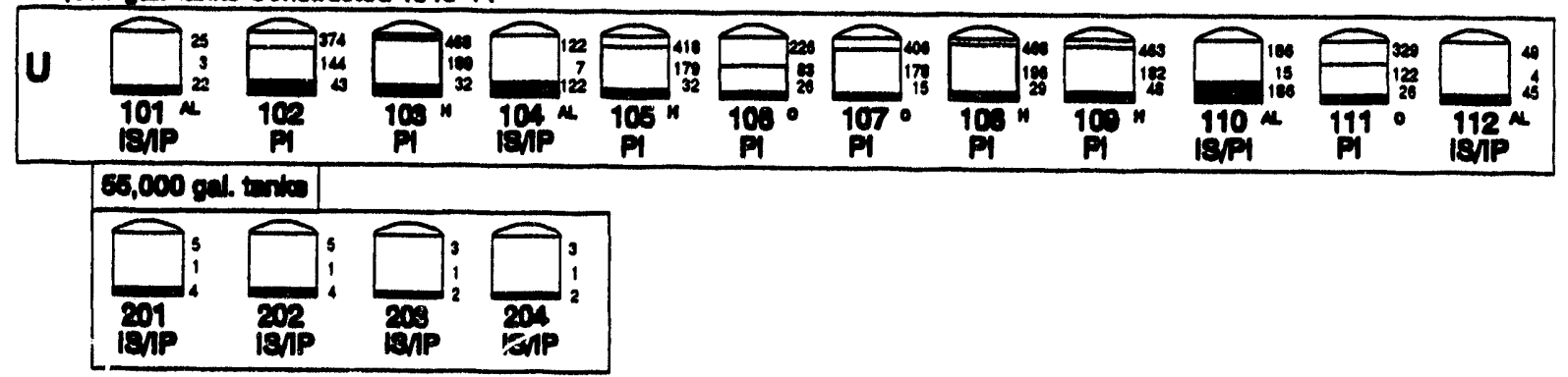

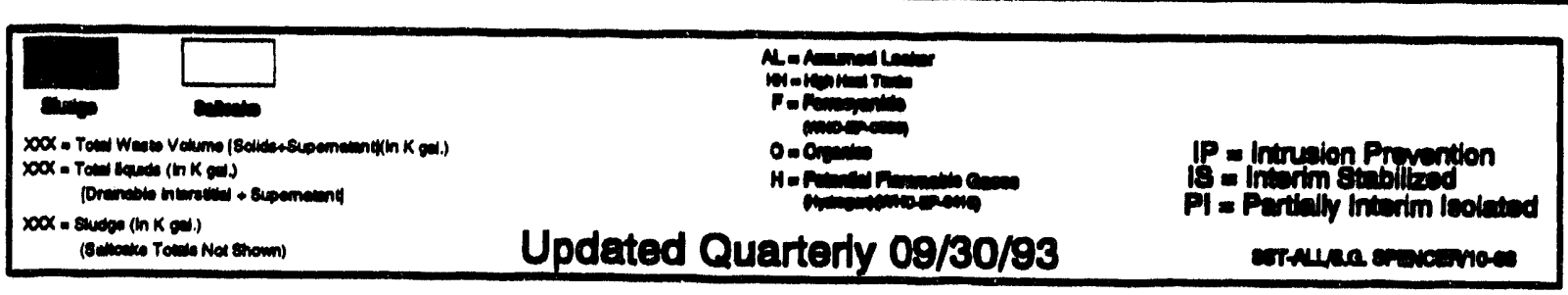

Fig. D-6. 200W Single-Shell Tank Status 


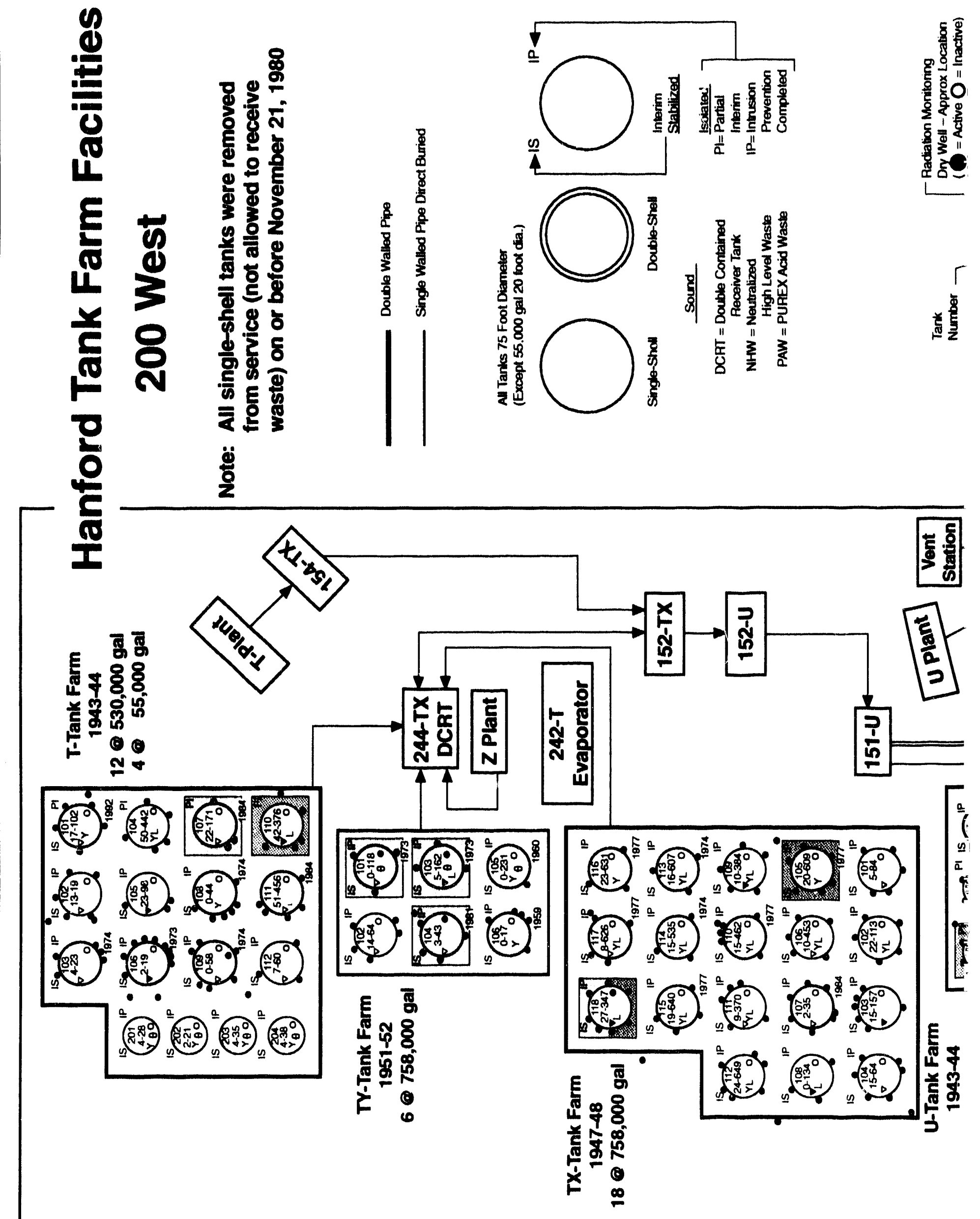




\section{Hanford Tank Farm Faci 200 East}

Note: All single-shell tanks were removed from service (not allowed to receive waste) on or before November 21, 1980

Single Walled Pipe Direct Buried

All Tanks 75 Foot Diameter

(Except 55.000 gal 20 foot dia.)
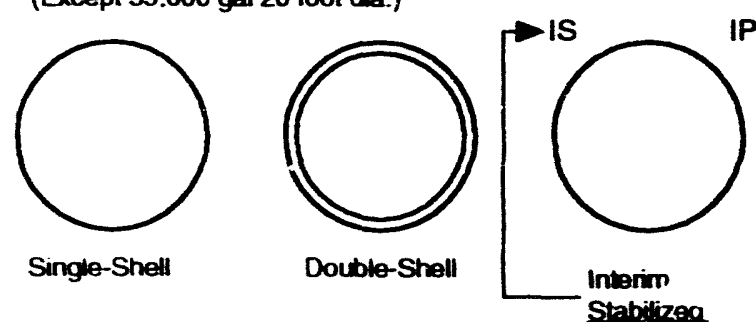

Sound

DCFT $=$ Double Contained NHW $=\begin{gathered}\text { Receiver Tank } \\ \text { Neutralized }\end{gathered}$

High Level Waste PAW = PUREX Acid Waste

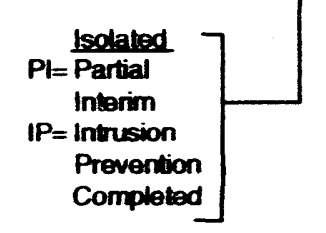

\section{BY-Tank Farm}

1948-49

$12 \odot 758,000 \mathrm{gal}$
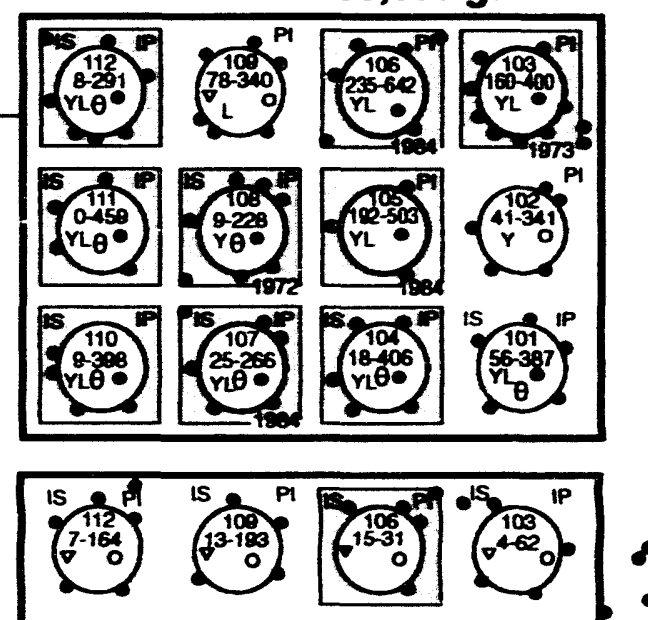

B-Tank Farm

$1943-44$

$12 \odot 530,000$ gal

4 C $55,000 \mathrm{gal}$

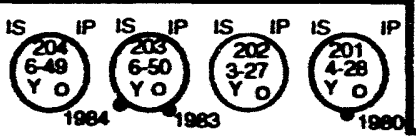

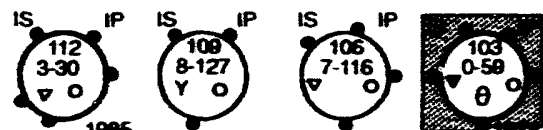

is If is if is If is If:

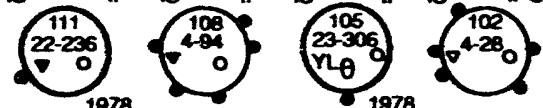

is is if is is is if

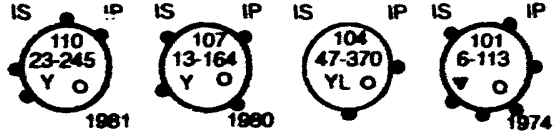

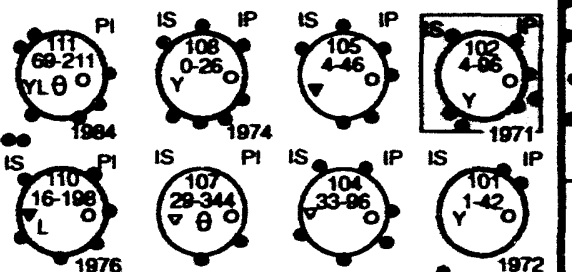

BX-Tank Farm

$1946-47$

$12 \odot 530,000 \mathrm{gal}$

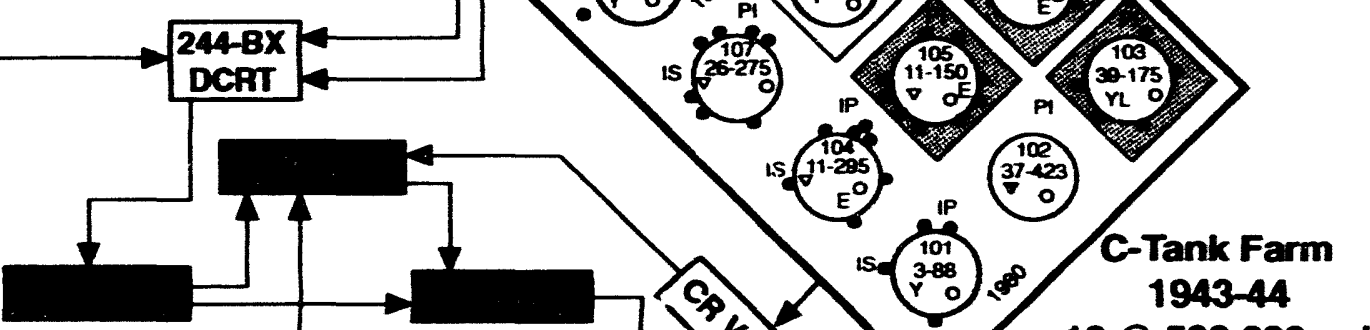
DCAT

\section{.}
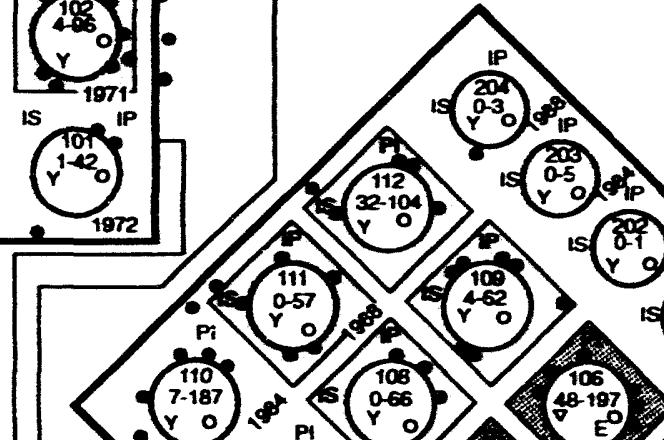

$\left(\begin{array}{ll}1187 \\ 1107\end{array}\right.$

$1943-44$

$12 \odot 530,000 \mathrm{gal}$

4 . $55,000 \mathrm{gal}$

AN-Tank Farm

1980-81

7 e 1,160,000 gal

(20) 


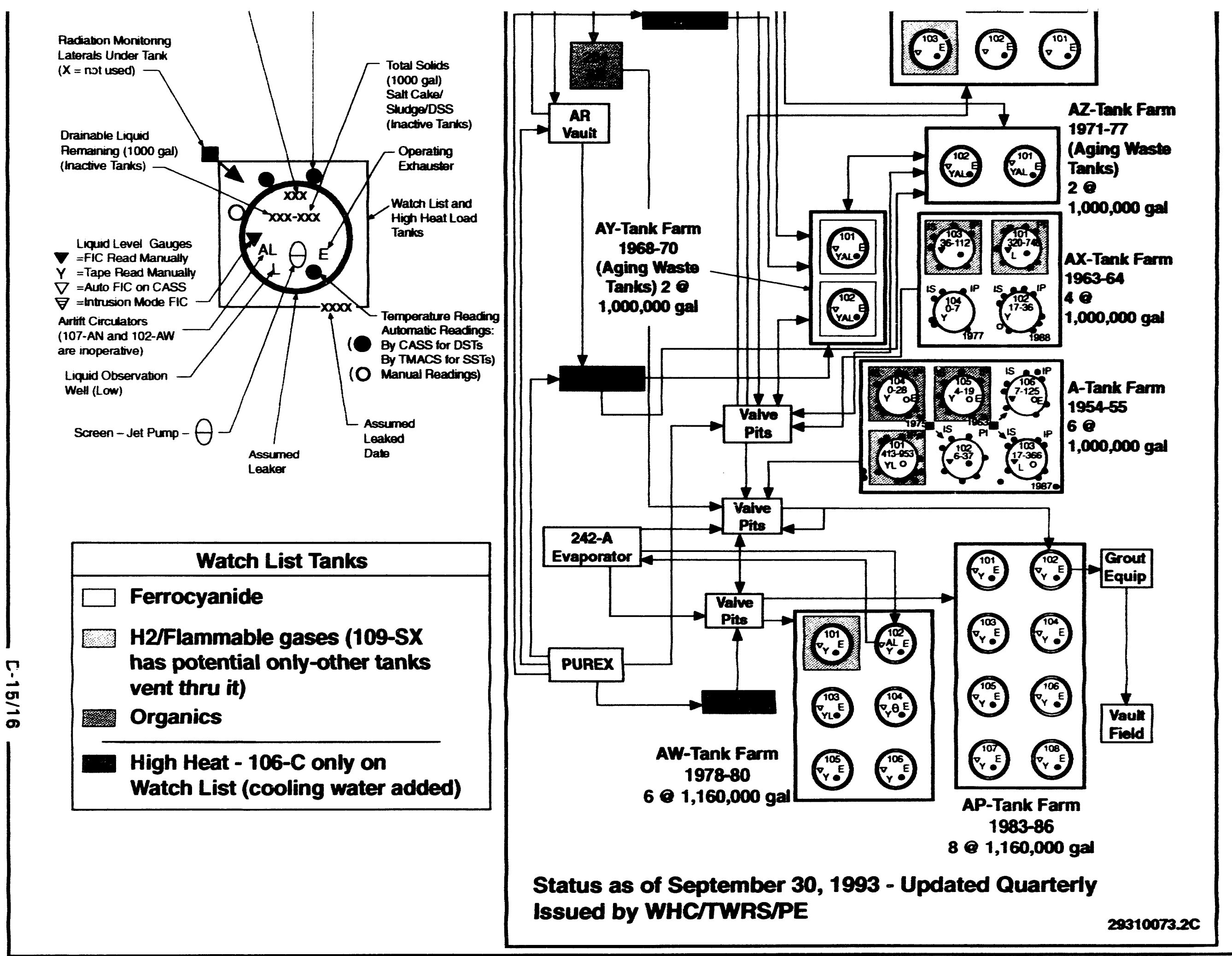


WHC-EP-0182-68

\title{
APPENDIX E
}

\author{
MONTHLY SUMMARY \\ TANK USE SUMMARY \\ INVENTORY SUMMARY BY TANK FARM \\ INVENTORY AND STATUS BY TANK
}


WHC-EP-0182-68

This page intentionally left blank. 


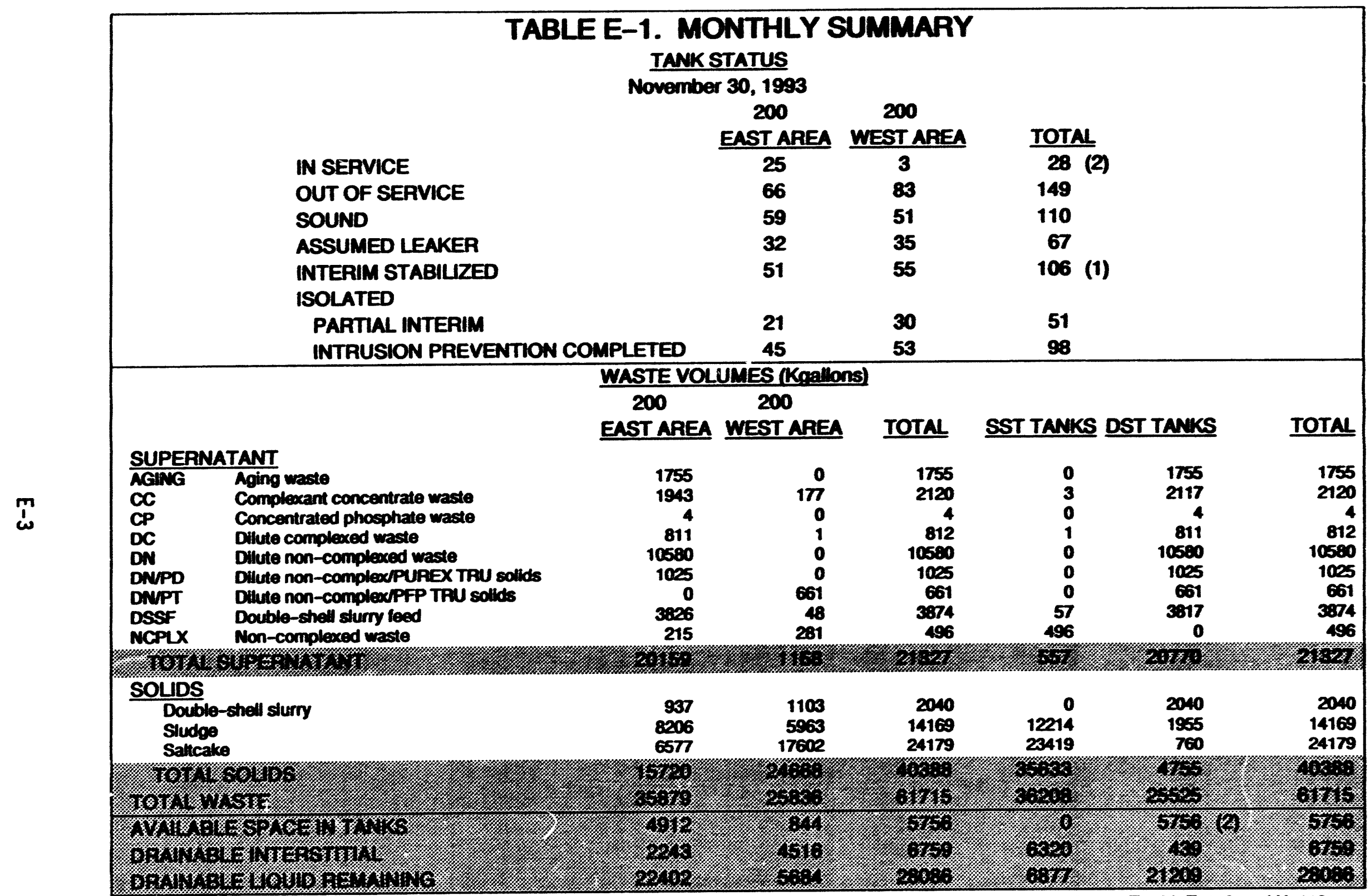

(1) Includes stx tanks that do not meet current established supernatant and interstitial liquid stabilization criteria, B-104, 110, 111, T-102, T-112, and U-110. (2) Includes six double-shell tanks on Hydrogen Watch List not currently allowed to recelve waste, 103-AN, 104-AN, 105-AN, 101-AW. 101-SY, and 103-SY. Nole: $+1-1 \mathrm{Kgal}$ differences are the result of computer rounding 

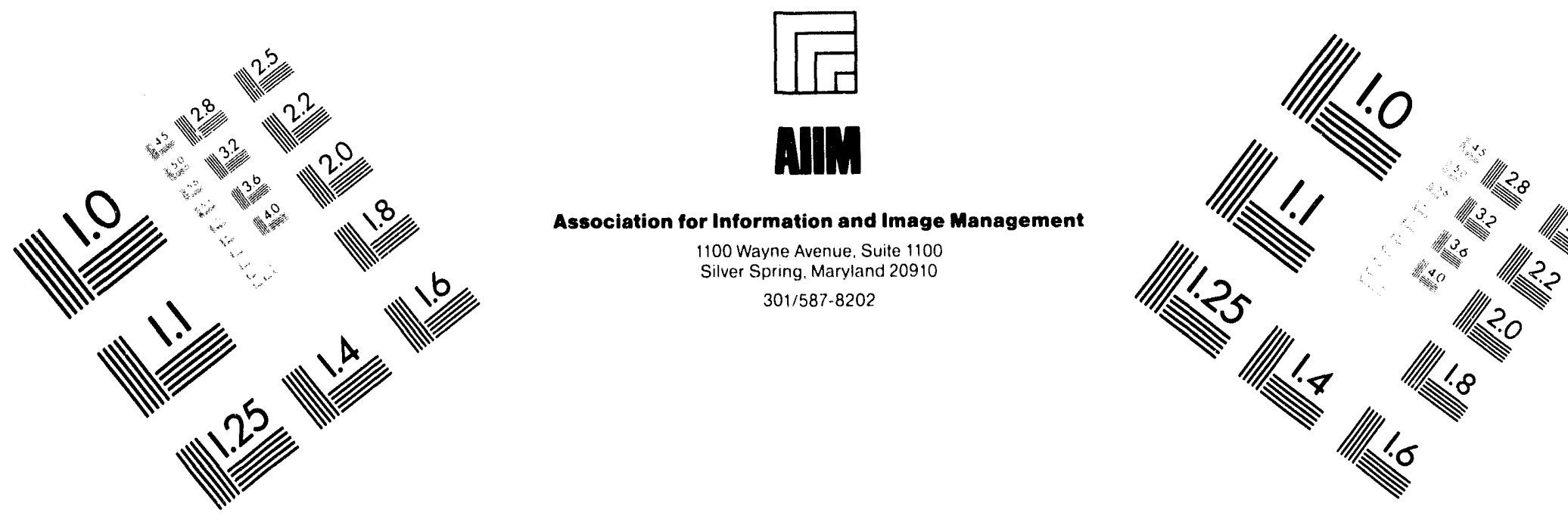

\section{Centimeter}

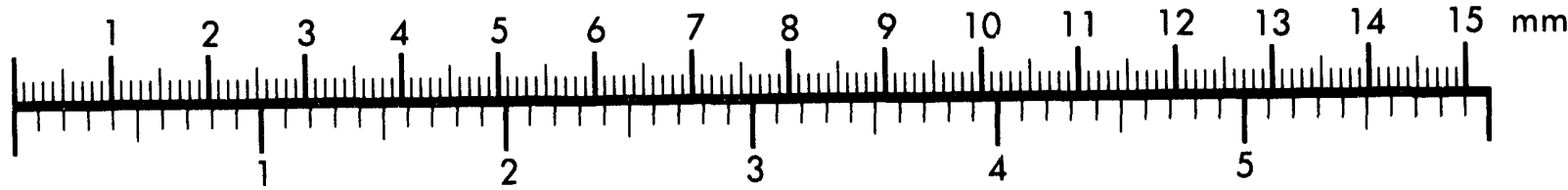

Inches
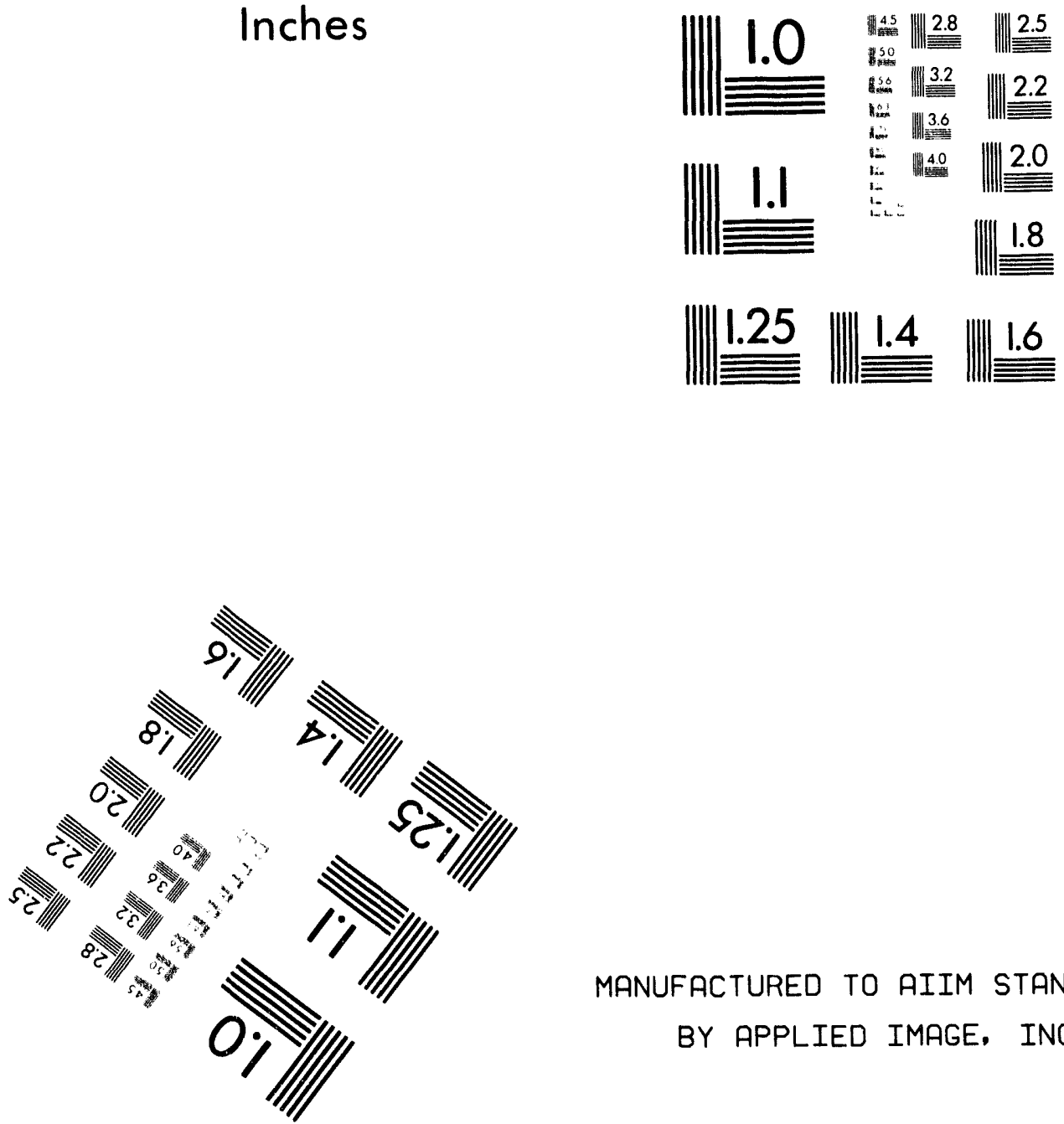

MANUFACTURED TO AIIM STANDARDS

BY APPLIED IMAGE, INC.

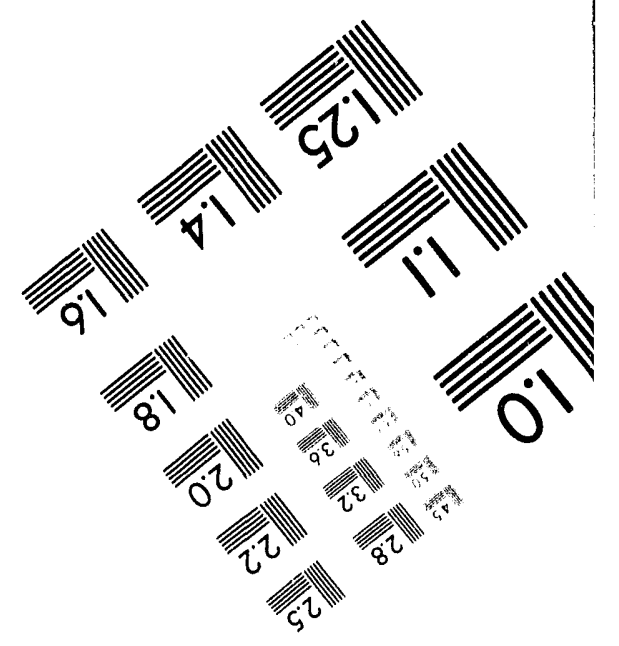



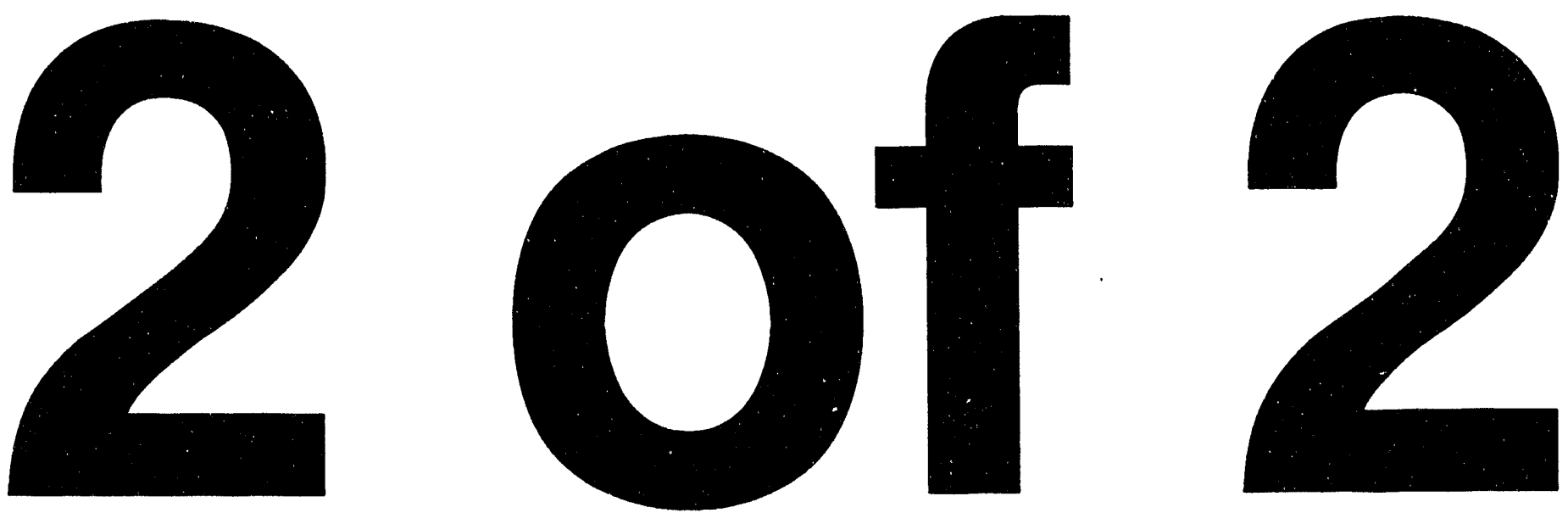
TABLE E-2. TANK USE SUMMARY

November 30, 1993

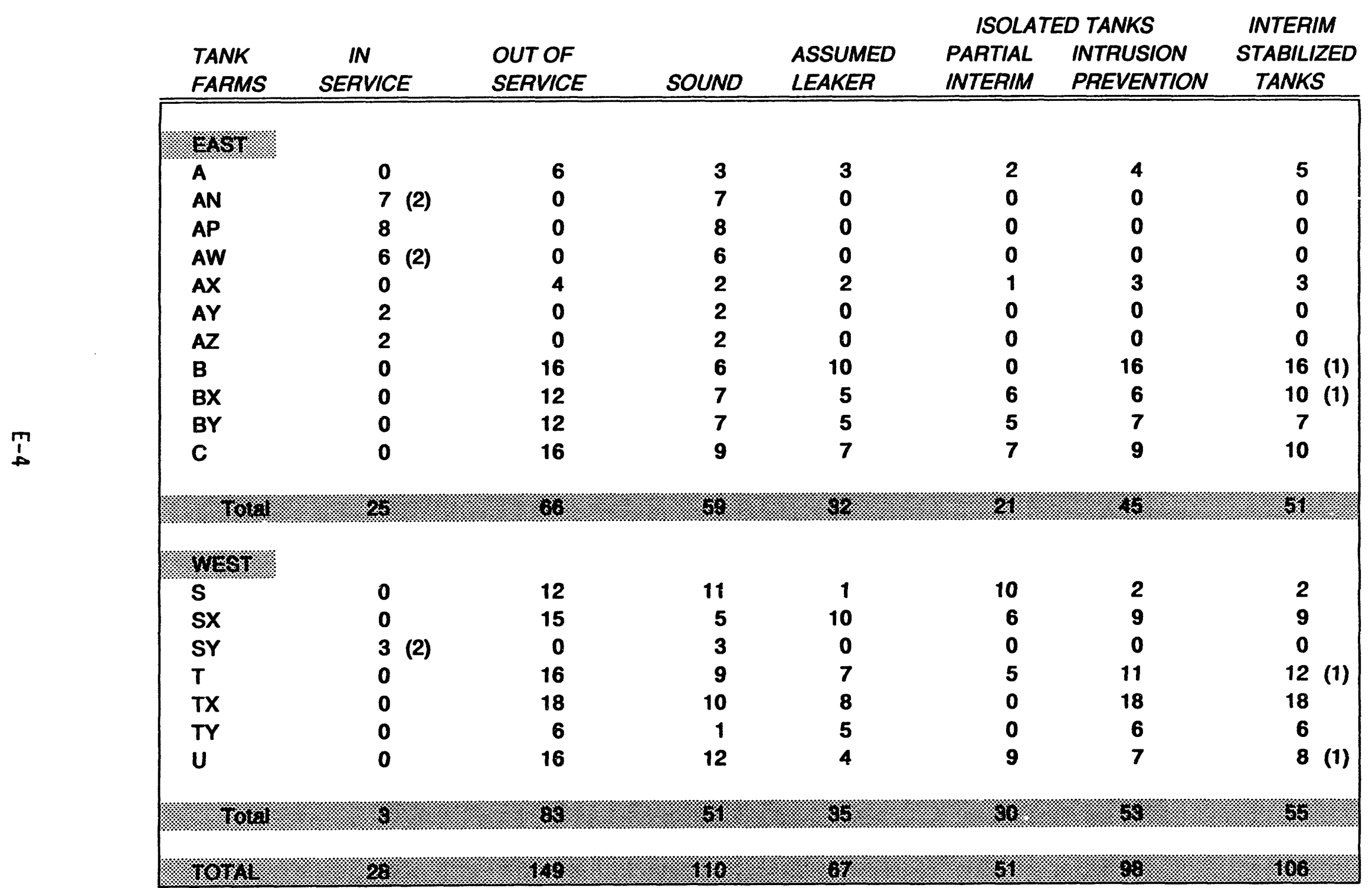

(1) Includes six tanks that do not meet current established supernatant and interstitial liquid stabilization criteria (B-104, 110, 111, T-102, 112, and $U-110$ ).

(2) Six Double-Shell Tanks on the Hydrogen Tank Watch List are not currently in service (AN-103, 104, 105, AW-101, SY-101 and 103). 
TABLE E-3. INVENTORY SUMMARY BY TANK FARM

WASTE VOLUMES (Kgallons)

November 30, 1993

SUPERNATANT LIQUID VOLUMES

SOLIDS VOLUME

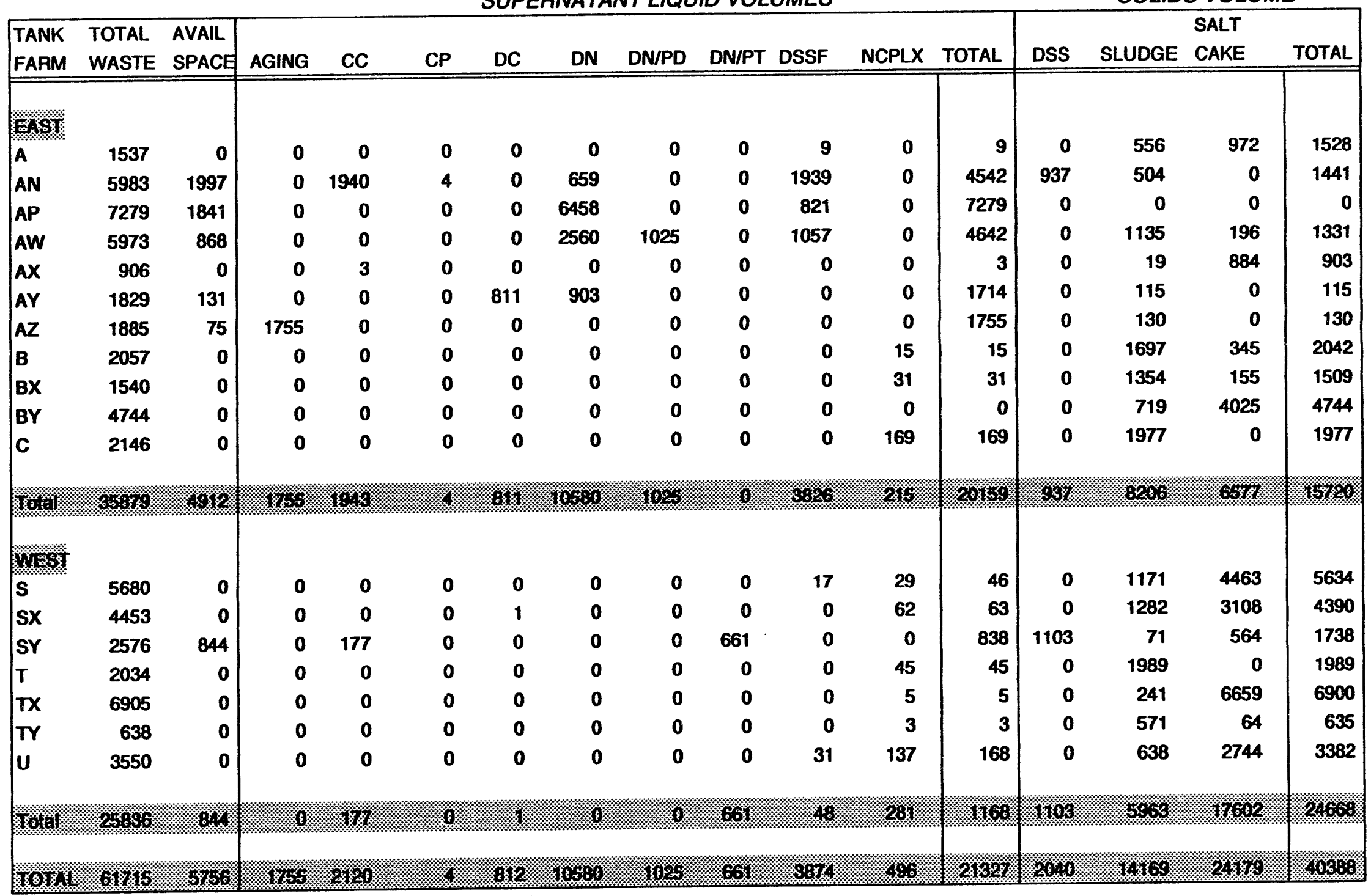


TABLE E-4. INVENTORY AND STATUS BY TANK

DOUBLE-SHELL TANKS

November 30, 1993

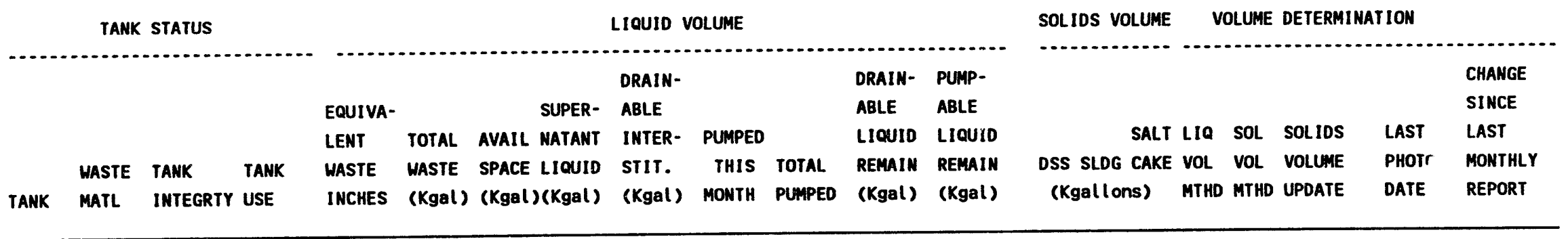

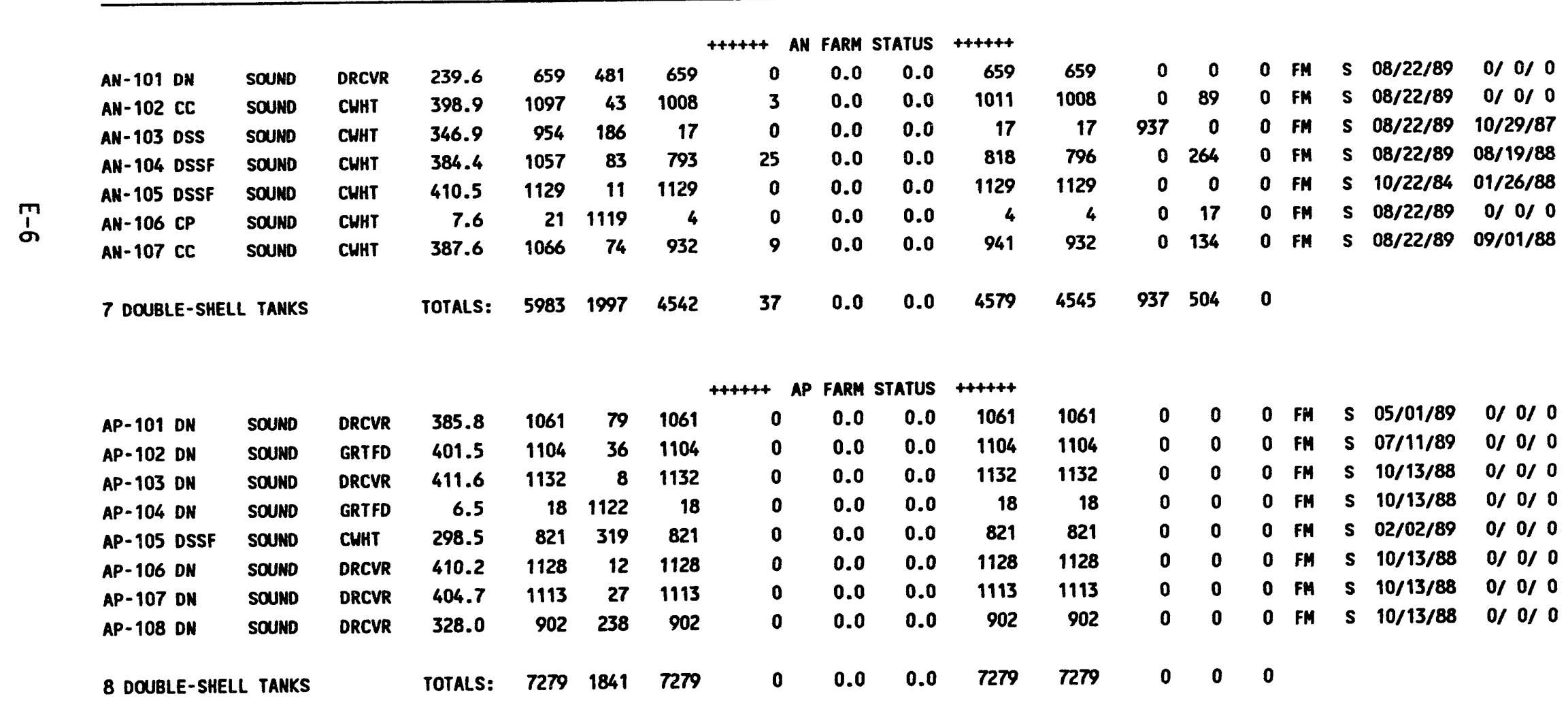


TABLE E-4. INVENTORY AND STATUS BY TANK DOUBLE-SHELL TANKS

November 30, 199?

\begin{tabular}{|c|c|c|c|c|c|c|c|c|c|c|c|c|c|c|c|c|c|c|}
\hline & TANK & STATUS & & & & & & LIOUID V & OLUME & & & & SOLIDS VOLUME & vo & DLUME & DETERMII & IION & \\
\hline ANK & $\begin{array}{l}\text { WASTE } \\
\text { MATL }\end{array}$ & $\begin{array}{l}\text { TANK } \\
\text { INTEGRTY }\end{array}$ & $\begin{array}{l}\text { TANK } \\
\text { USE }\end{array}$ & $\begin{array}{l}\text { EQUIVA- } \\
\text { LENT } \\
\text { MASTE } \\
\text { INCHES }\end{array}$ & $\begin{array}{l}\text { TOTAL } \\
\text { WASTE } \\
\text { (Kgal) }\end{array}$ & $\begin{array}{l}\text { AVAIL } \\
\text { SPACE } \\
\text { (Kgal) }\end{array}$ & $\begin{array}{l}\text { SUPER- } \\
\text { MATANT } \\
\text { LIOUID } \\
\text { (Kgal) }\end{array}$ & $\begin{array}{l}\text { DRAIN- } \\
\text { ABLE } \\
\text { INTER- } \\
\text { STIT. } \\
\text { (Kgal) }\end{array}$ & $\begin{array}{l}\text { PUMPED } \\
\text { THIS } \\
\text { MONTH }\end{array}$ & $\begin{array}{l}\text { TOTAL } \\
\text { PUMPED }\end{array}$ & $\begin{array}{l}\text { DRAIN- } \\
\text { ABLE } \\
\text { LIQUID } \\
\text { REMAIN } \\
\text { (Kgal) }\end{array}$ & $\begin{array}{l}\text { PUMP- } \\
\text { ABLE } \\
\text { LIQUID } \\
\text { REMAIN } \\
\text { (Kgal) }\end{array}$ & $\begin{array}{r}\text { SALT } \\
\text { DSS SLDG CAKE } \\
\text { (Kgallons) }\end{array}$ & $\begin{array}{l}\text { LIQ } \\
\text { VOL } \\
\text { MTHD }\end{array}$ & $\begin{array}{l}\text { SOL } \\
\text { VOL } \\
\text { MTHD }\end{array}$ & $\begin{array}{l}\text { SOLIDS } \\
\text { VOLUME } \\
\text { UPDATE }\end{array}$ & $\begin{array}{l}\text { LAST } \\
\text { PHOTO } \\
\text { DATE }\end{array}$ & $\begin{array}{l}\text { CHANGE } \\
\text { SINCE } \\
\text { LAST } \\
\text { MONTHLY } \\
\text { REPORT }\end{array}$ \\
\hline
\end{tabular}

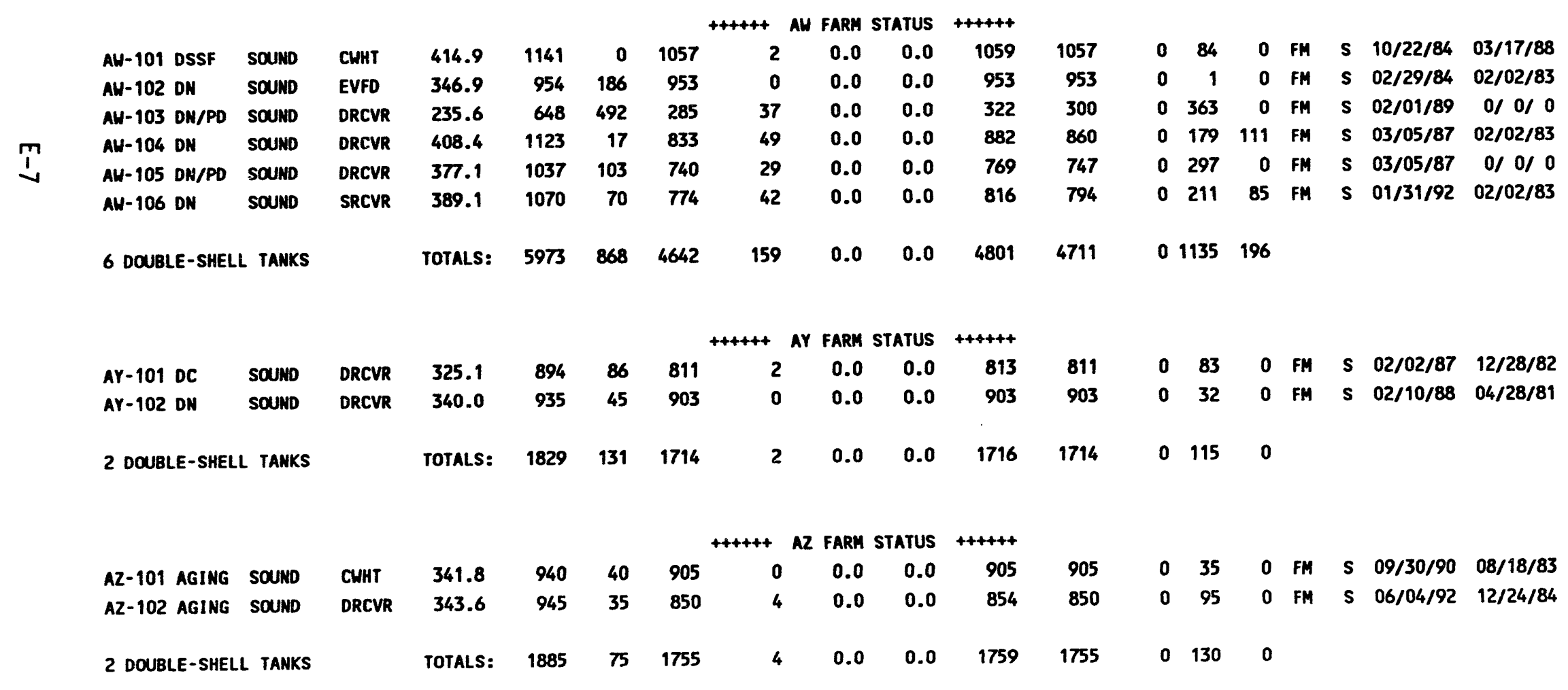


TABLE E-4. INVENTORY AND STATUS BY TANK

DOUBLE-SHELL TANKS

November 30, 1993

TANK STATUS

MASTE TANK TANK

LIQUID VOLUME

DRAIN-

EQUIVA-

LENT TOTAL AVAIL NATANT INTER- PUMPED

WASTE WASTE SPACE LIOUID STIT.

INCHES (Kgal) (Kgal)(Kgal) (Kgal) MONTH PUMPED

TANK MATL INTEGRTY USE INCHES (Kgal) (Kgal)(Kgal) (Kgal) MONTH PUMPED (Kgal) (Kgal)

\begin{tabular}{|c|c|c|c|c|c|c|c|c|c|c|c|c|c|c|c|c|c|c|}
\hline & & & & & & & $+++\leq$ & SY FARM & STATUS & ++++++ & & & & & & & & \\
\hline sY-101 CC & SOUND & CWHT & 400.4 & 1101 & 39 & 11 & 237 & 0.0 & 0.0 & 248 & 242 & 530 & 0 & 560 & FM & $\mathbf{s}$ & $01 / 31 / 92$ & $04 / 12 / 89$ \\
\hline SY-102 DN/PT & SOUND & DRCVR & 266.2 & 732 & 408 & 661 & 0 & 0.0 & 0.0 & 661 & 661 & 0 & 71 & 0 & $\mathbf{F M}$ & $\mathbf{s}$ & $05 / 12 / 87$ & $04 / 29 / 81$ \\
\hline sy-103 cC & SOUND & CUHT & 270.2 & 743 & 397 & 166 & 0 & 0.0 & 0.0 & 166 & 166 & 573 & $\mathbf{0}$ & 4 & $\mathbf{F M}$ & $\mathbf{s}$ & $10 / 22 / 84$ & $10 / 01 / 85$ \\
\hline 3 DOUBLE-SHELL & L TANKS & & TOTALS: & 2576 & 844 & 838 & 237 & 0.0 & 0.0 & 1075 & 1069 & 1103 & 71 & 564 & & & & \\
\hline GRAND TOTAL & & & & 25525 & 5756 & 20770 & 439 & & & 21209 & 21073 & 2040 & 955 & 760 & & & & \\
\hline
\end{tabular}

Note: $+1-1 \mathrm{Kgal}$ differences are the result of computer rounding

\begin{tabular}{|c|c|c|c|c|}
\hline \multirow[b]{2}{*}{ Tank Farms } & \multirow{2}{*}{$\begin{array}{l}\text { Available Space } \\
\text { Calculations Used } \\
\text { In This Document } \\
\text { (Most Conservative) }\end{array}$} & \multicolumn{2}{|c|}{ Document SD-LM-TI-357* } & \multirow{2}{*}{$\begin{array}{l}\text { Document } \\
\text { OSD-T-151-00007** } \\
\text { Specification Limit }\end{array}$} \\
\hline & & Operating Limit & Tank Capacity & \\
\hline $\begin{array}{l}\text { AN, AP, AW, SY } \\
\text { AY, AZ (Aging Haste) }\end{array}$ & $\begin{array}{r}1,140,000 \mathrm{gal}(414.5 \text { in.) } \\
980,000 \mathrm{gal}(356.4 \text { in.) }\end{array}$ & $\begin{array}{r}1,144,000 \mathrm{gal}(416 \text { in.) } \\
990,000 \mathrm{gal}(360 \text { in.) }\end{array}$ & $\begin{array}{l}1,160,000 \text { gal (421.8 in.) } \\
1,000,000 \text { gal }(363.6 \text { in.) }\end{array}$ & $\begin{array}{l}1,160,500 \text { gal (422 in.) } \\
1,001,000 \text { gal (364 in.) }\end{array}$ \\
\hline
\end{tabular}

* WHC-SD-WM-T1-357, "Haste Storage Tank Status and Leak Detection Criteria."

**HHC-OSD-T-151-00007, "Operating Specifications for 241-AN, AP, AH, AY, AZ, \& SY Tank Farms."

(1) Tank AH-101: Al though the total waste exceeds the $1140 \mathrm{Kgal}$ specified for waste volume projections of available space, it does not exceed the operating limit criteria. 
TABLE E-5. INVENTORY AND STATUS BY TANK SINGLE-SHELL TANKS November 30, 1993

\begin{tabular}{|c|c|c|c|c|c|c|c|c|c|c|c|c|c|c|c|c|c|c|c|}
\hline \multirow[b]{2}{*}{ TANK } & \multicolumn{2}{|c|}{ TANK STATUS } & \multicolumn{8}{|c|}{ LIQUID VOLUME } & \multicolumn{2}{|c|}{ SOLIDS VOLUME } & \multicolumn{5}{|c|}{ VOLUME DETERMINATION } & \multirow[b]{2}{*}{$\begin{array}{l}\text { CHG } \\
\text { SINCE } \\
\text { LAST } \\
\text { MNTHLY } \\
\text { REPORT }\end{array}$} & \\
\hline & $\begin{array}{l}\text { WASTE } \\
\text { MATERIAL }\end{array}$ & $\begin{array}{c}\text { TANK } \\
\text { INTEGRITY }\end{array}$ & $\begin{array}{l}\text { STABIL/ } \\
\text { ISOLATION } \\
\text { STATUS }\end{array}$ & $\begin{array}{l}\text { TOTAL } \\
\text { WASTE } \\
\text { (Kgal) }\end{array}$ & $\begin{array}{l}\text { SUPER- } \\
\text { MATANT } \\
\text { LIQUID } \\
\text { (Kgal) }\end{array}$ & $\begin{array}{l}\text { DRAIN- } \\
\text { ABLE } \\
\text { INTER- } \\
\text { STIT. } \\
\text { (Kgal) }\end{array}$ & $\begin{array}{l}\text { PUMPED } \\
\text { THIS } \\
\text { MONTH } \\
\text { (Kgal) }\end{array}$ & $\begin{array}{l}\text { TOTAL } \\
\text { PUMPED } \\
\text { (Kgal) }\end{array}$ & $\begin{array}{l}\text { DRAIN- } \\
\text { ABLE } \\
\text { LIQUID } \\
\text { REMAIN } \\
\text { (Kgal) }\end{array}$ & $\begin{array}{l}\text { PUMP- } \\
\text { ABLE } \\
\text { LIQUID } \\
\text { REMAIN } \\
\text { (Kgal) }\end{array}$ & $\begin{array}{l}\text { SLUDGE } \\
\text { (Kgal) }\end{array}$ & $\begin{array}{l}\text { SALTCAKE } \\
\text { (Kgal) }\end{array}$ & $\begin{array}{l}\text { LIQUIDS } \\
\text { VOLUME } \\
\text { METHOD }\end{array}$ & $\begin{array}{l}\text { SOLIDS } \\
\text { VOLUME } \\
\text { METHOO }\end{array}$ & $\begin{array}{l}\text { SOLIOS } \\
\text { VOLUME } \\
\text { UPOATE }\end{array}$ & $\begin{array}{l}\text { SOLIDS } \\
\text { UPDATE } \\
\text { SOURCE } \\
\text { SEE } \\
\text { FOOTNOTE }\end{array}$ & $\begin{array}{l}\text { LAST } \\
\text { PHOTO } \\
\text { DATE }\end{array}$ & & \\
\hline & & & & & & +t+t++ & A FARM $S$ & Status & +t+++t & & & & & & & & & & \\
\hline$A-101$ & DSSF & SOUND & IPI & 953 & 0 & 413 & 0.0 & 0.0 & 413 & 390 & 3 & 950 & $\mathbf{P}$ & $\mathbf{F}$ & $11 / 21 / 80$ & & $08 / 21 / 85$ & & \\
\hline$A-102$ & DSSF & SOUND & IS/PI & 41 & 4 & 2 & 0.0 & 39.5 & 6 & 0 & 15 & 22 & $\mathbf{P}$ & FP & $07 / 27 / 89$ & (1) & $07 / 20 / 89$ & & Tु \\
\hline A-103 & DSSF & ASMD LKR & IS/IP & 371 & 5 & 15 & 0.0 & 111.0 & 20 & 0 & 366 & 0 & - & FP & $06 / 03 / 88$ & (1) & $12 / 28 / 88$ & & \\
\hline$A-104$ & NCPLX & ASMD LKR & IS/IP & 28 & 0 & 0 & 0.0 & 0.0 & 0 & 0 & 28 & 0 & $M$ & PS & $01 / 27 / 78$ & & $06 / 25 / 86$ & & $\stackrel{\infty}{\infty}$ \\
\hline$A-105$ & NCPLX & ASMD LKR & IS/IP & 19 & 0 & 4 & 0.0 & 0.0 & 4 & 0 & 19 & 0 & $\mathbf{P}$ & MP & $08 / 23 / 79$ & (1) & $08 / 20 / 86$ & & \\
\hline$A-106$ & CP & SOUND & IS/IP & 125 & 0 & 7 & 0.0 & 0.0 & 7 & 0 & 125 & 0 & $\mathbf{P}$ & $M$ & $09 / 07 / 82$ & & $08 / 17 / 86$ & & $\infty$ \\
\hline 6 SINGL & LE-SHELL T & TANKS & TOTALS & 1537 & 9 & 441 & 0.0 & 150.5 & 450 & 390 & 556 & 972 & & & & & & & \\
\hline & & & & & & ++++++ & AX FARM & STATUS & $+++++t$ & & & & & & & & & & \\
\hline$A X-101$ & DSSF & SOUND & /PI & 748 & 0 & 320 & 0.0 & 0.0 & 320 & 298 & 3 & 745 & $\mathbf{P}$ & $F$ & $05 / 06 / 82$ & & $08 / 18 / 87$ & & \\
\hline$A X-102$ & cc & ASMD LKR & IS/IP & 39 & 3 & 14 & 0.0 & 13.0 & 17 & 3 & 7 & 29 & $\mathbf{F}$ & s & $09 / 06 / 88$ & & $06 / 05 / 89$ & & \\
\hline$A X-103$ & CC & SOUND & IS/IP & 112 & 0 & 36 & 0.0 & 0.0 & 36 & 3 & 2 & 110 & $\mathbf{F}$ & s & $08 / 19 / 87$ & & $08 / 13 / 87$ & & \\
\hline$A X-104$ & NCPLX & ASMD LKR & IS/IP & 7 & 0 & 0 & 0.0 & 0.0 & 0 & 0 & 7 & 0 & $\mathbf{P}$ & $M$ & $04 / 28 / 82$ & & $08 / 18 / 87$ & & \\
\hline 4 SINGI & LE-SHELL T & TANKS & TOTALS: & 906 & 3 & 370 & 0.0 & 13.0 & 373 & 304 & 19 & 884 & & & & & & & \\
\hline
\end{tabular}


TABLE E-5. INVENTORY AND STATUS BY TANK

SINGLE-SHELL TANKS

November 30, 1993

TANK STATUS

MASTE TANK

TANK MATERIAL INTEGRITY STATUS
LLQUID VOLUME

DRAIN-
SUPER- ABLE PUMPED
ABLE ABL - PUMP-

STABIL/ TOTAL NATANT INTER- THIS TOTAL LIQUID LIOUID MASTE LIQUID STIT. MONTH PUMPED REMAIN REMAIN (Kgal) (Kgal) (Kgal) (Kgal) (Kgal) (Kgal) (Kgal)
SOLIDS VOLUME

\begin{tabular}{|c|c|c|c|c|c|}
\hline & & & SOLIDS & & CHG \\
\hline & & & UPDATE & & SINCE \\
\hline LIQUIDS & SOLIDS & SOLIDS & SOURCE & LAST & LAST \\
\hline VOLUHE & VOLUME & VOLUME & SEE & РноTо & MNTHLY \\
\hline METHOD & METHOO & UPDATE & FOOTNOTE & DATE & REPORT \\
\hline
\end{tabular}

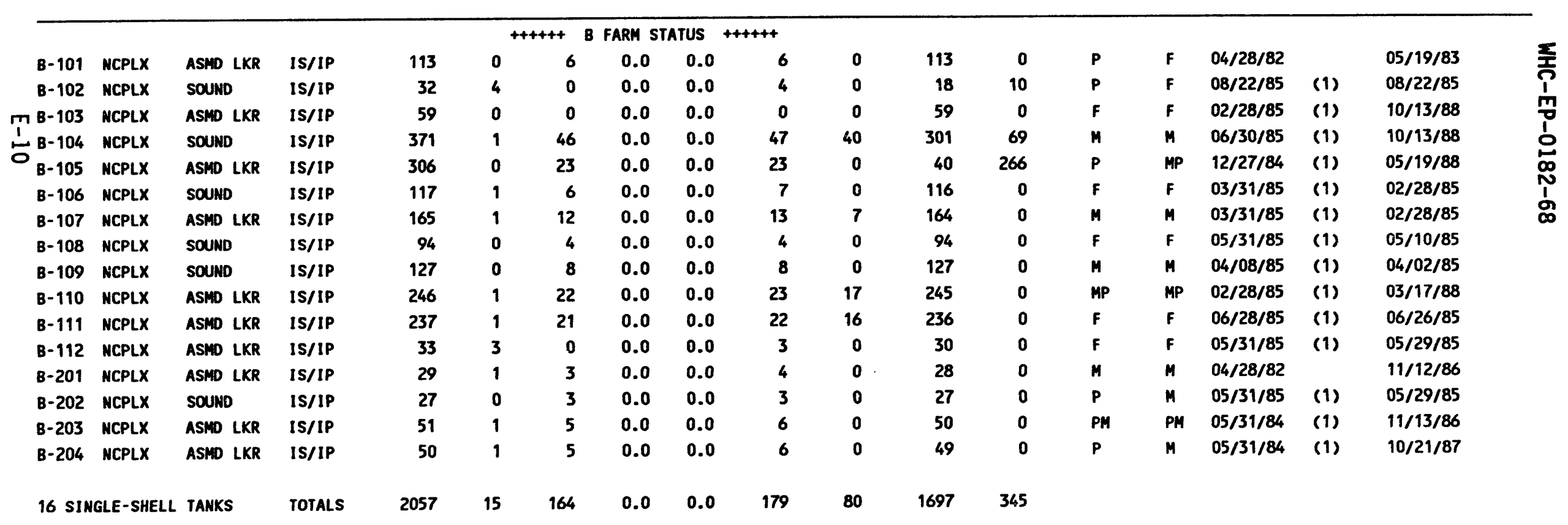


TABLE E-5. INVENTORY AND STATUS BY TANK

SINGLE-SHELL TANKSS

November 30, 1993

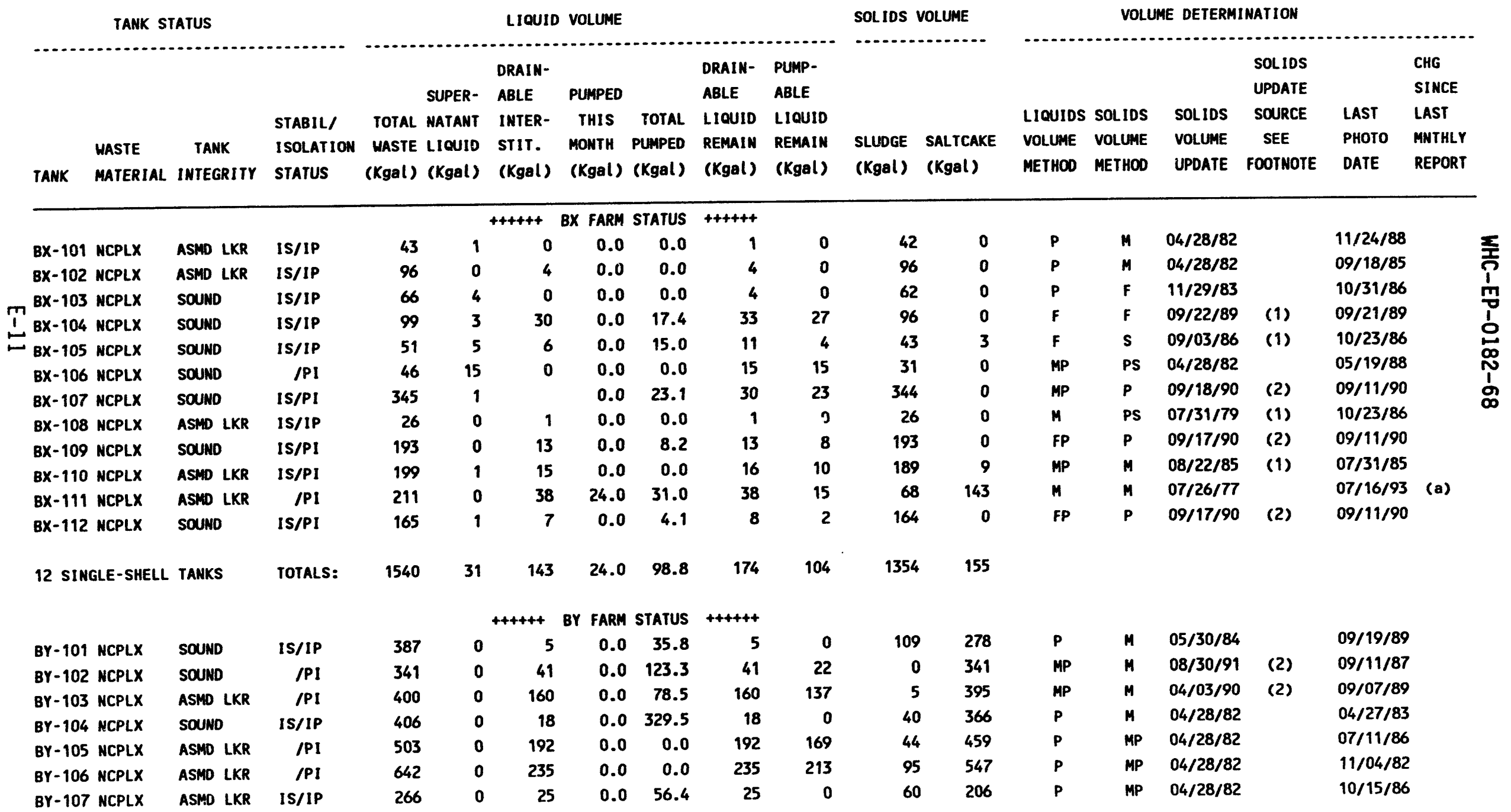


TABLE E-5. INVENTORY AND STATUS BY TANK

SINGLE-SHELL TANKS

November 30,1993

TANK STATUS

TANK MATERIAL INTEGRITY STATUS

MASTE TANK TSO

SOLIDS VOLUME

DRAIN-

SUPER- ABLE PUMPED

STABIL/ TOTAL NATANT INTER- THIS TOTAL LIQUID LIQUID

ISOLATION MASTE LIQUID STIT. MONTH PUMPED REMAIN REMAIN

BY-108 NCPLX ASMO LKR IS/IP

BY-109 MCPLX

BY-110 NCPLX

BY-111 NCPLX

SOUND IPI

SOUND IS/IP

SOUMD ISIIP

SOUND

IS/IP

TOTALS:

12 SINGLE-SHELL TANKS

C-101 NCPLX

C- 102 DC

C-103 NCPLX

C-104 CC

C-105 NCPLX

C-106 MCPLX

C-107 DC

C-108 NCPLX

C-109 NCPLX

$C-110$ DC

C-111 NCPLX

C-112 NCPLX

$\begin{array}{lr}\text { ASMD LKR } & \text { IS/IP } \\ \text { SOUND } & / P I \\ \text { SOUND } & / P I \\ \text { SOUND } & I S / I P \\ \text { SOUND } & / P I \\ \text { SOUND } & / P I \\ \text { SOUND } & / P I \\ \text { SOUND } & \text { IS/IP } \\ \text { SOUND } & \text { IS/IP } \\ \text { ASMD LKR } & / P I \\ \text { ASMD LKR } & \text { IS/IP } \\ \text { SOUND } & \text { IS/PI }\end{array}$

228
423
398
459
291

$\begin{array}{rrrr}0.0 & 27.5 & 9 & 0 \\ 0.0 & 93.5 & 78 & 57\end{array}$

0.0213 .3

0.0313 .2

0.0116 .4

....................

(Kgal) (Kgal)

4744

$\begin{array}{llllll}0.0 & 1387.4 & 780 & 598 & 719 & 4025\end{array}$

++++t+ C FARM STATUS ++++++

$\begin{array}{rrrrrrr}88 & 0 & 3 & 0.0 & 0.0 & 3 & 0 \\ 423 & 0 & 37 & 0.0 & 11.6 & 37 & 19 \\ 195 & 133 & 0 & 0.0 & 0.0 & 133 & 133 \\ 295 & 0 & 11 & 0.0 & 0.0 & 11 & 5 \\ 150 & 0 & 11 & 0.0 & 0.0 & 11 & 4 \\ 229 & 32 & 16 & 0.0 & 0.0 & 48 & 42 \\ 275 & 0 & 26 & 0.0 & 16.3 & 26 & 20 \\ 66 & 0 & 0 & 0.0 & 0.0 & 0 & 0 \\ 66 & 4 & 0 & 0.0 & 0.0 & 4 & 0 \\ 187 & 0 & 7 & 0.0 & 8.9 & 7 & 5 \\ 57 & 0 & 0 & 0.0 & 0.0 & 0 & 0 \\ 104 & 0 & 32 & 0.0 & 0.0 & 32 & 26\end{array}$

$\begin{array}{rl}88 & 0 \\ 423 & 0 \\ 62 & 0 \\ 295 & 0 \\ 150 & 0 \\ 197 & 0 \\ 275 & 0 \\ 66 & 0 \\ 62 & 0 \\ 187 & 0 \\ 57 & 0 \\ 104 & 0\end{array}$

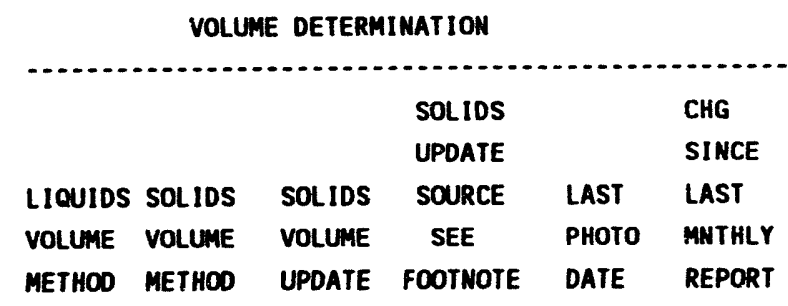

$M$
$F$
$F$
$F P$
$F$
$F$
$F$
$M$
$M$
$F$
$M$
$M$

M
S
P
S
PS
S
S
PS
FMP
S
PS

$11 / 29 / 83$
$04 / 28 / 82$
$10 / 22 / 90$
$09 / 22 / 89$
$05 / 31 / 85$
$04 / 28 / 82$
$01 / 30 / 92$
$02 / 24 / 84$
$11 / 29 / 83$
$03 / 01 / 92$
$04 / 28 / 82$
$09 / 18 / 90$

$\begin{array}{ll} & 11 / 17 / 87 \\ & 05 / 18 / 76 \\ \text { (2) } & 07 / 28 / 87 \\ \text { (1) } & 07 / 25 / 90 \\ & 04 / 01 / 88 \\ & 04 / 05 / 79 \\ \text { (2) } & 00 / 00 / 00 \\ \text { (1) } & 12 / 05 / 74 \\ & 01 / 30 / 76 \\ \text { (2) } & 08 / 12 / 86 \\ & 02 / 25 / 70 \\ \text { (2) } & 09 / 18 / 90\end{array}$

$\begin{array}{llll}04 / 28 / 82 & & 10 / 15 / 86 \\ 08 / 30 / 91 & \text { (2) } & 10 / 15 / 86 \\ 09 / 10 / 79 & & 07 / 26 / 84 \\ 04 / 28 / 82 & & 10 / 31 / 86 \\ 04 / 28 / 82 & & 04 / 14 / 88\end{array}$


TABLE E-5. INVENTORY AND STATUS BY TANK

SINGLE-SHELL TAHKS

November 30, 1993

TANK STATUS

MASTE TANK ISO

TANK MATERIAL INTEGRITY STATUS
LIOUID VOLUME

DRAIN-

SUPER- ABLE

TOTAL NATANT INTER- THIS TOTAL LIOUID LIOUID

MOUTH PIMPED REMAIM REMAIM

\begin{tabular}{llllllllll}
\hline C-201 NCPLX ASHD LKR & IS/IP & 2 & 0 & 0 & 0.0 & 0.0 & 0 & 0
\end{tabular}

C-202 EMPTY ASHD LKR IS/IP

C-203 NCPLX ASHD LKR IS/IP

TI C-204 NCPLX ASMD LKR IS/IP $\stackrel{1}{\omega}$

16 SINGLE-SHELL TANKS

TOTALS:

$\begin{array}{lllrl}\text { S-101 } & \text { NCPLX } & \text { SOUND } & \text { /PI } & 427 \\ \text { S-102 } & \text { DSSF } & \text { SOUND } & \text { /PI } & 549 \\ \text { S-103 } & \text { DSSF } & \text { SOUND } & \text { /PI } & 248 \\ \text { S-104 } & \text { NCPLX } & \text { ASWD LKR } & \text { IS/IP } & 294 \\ \text { S-105 } & \text { NCPLX } & \text { SOUND } & \text { IS/IP } & 456 \\ \text { S-106 } & \text { NCPLX } & \text { SOUND } & / P I & 543 \\ \text { S-107 } & \text { NCPLX } & \text { SOUND } & / P I & 368 \\ \text { S-108 } & \text { NCPLX } & \text { SOUND } & \text { /PI } & 604 \\ \text { S-109 } & \text { NCPLX } & \text { SOUND } & / P I & 568 \\ \text { S-110 } & \text { NCPLX } & \text { SOUND } & / P I & 390 \\ \text { S-111 } & \text { NCPLX } & \text { SOUND } & / P I & 596 \\ \text { S-112 } & \text { NCPLX } & \text { SOUND } & / P I & 637\end{array}$

12 SINGLE-SHELL TANKS

$\begin{array}{rr} & \text { ++t+++ S } \\ 12 & 84 \\ 0 & 230 \\ 17 & 85 \\ 1 & 28 \\ 0 & 35 \\ 0 & 185 \\ 6 & 45 \\ 0 & 127 \\ 0 & 141 \\ 0 & 110 \\ 10 & 195 \\ 0 & 134\end{array}$

SOLIDS VOLUME

\begin{tabular}{|c|c|c|c|c|c|}
\hline & & & SOLIDS & & CHG \\
\hline & & & UPDATE & & SINCE \\
\hline LIQUIDS & SOLIDS & SOLIDS & SOURCE & LAST & LAST \\
\hline VOLUME & VOLUME & VOLUME & SEE & РНОТО & MNTHLY \\
\hline METHOD & METHOD & UPDATE & FCOTNOTE & DATE & REPORT \\
\hline
\end{tabular}

VOLUME DETERMINATION

\begin{tabular}{|c|c|c|}
\hline MP & $03 / 31 / 82$ & $12 / 02 / 86$ \\
\hline$M$ & $01 / 19 / 79$ & $12 / 09 / 86$ \\
\hline MP & $04 / 28 / 82$ & $12 / 09 / 86$ \\
\hline MP & $04 / 28 / 82$ & $12 / 09 / 86$ \\
\hline
\end{tabular}

$03 / 18 / 88$

$03 / 18 / 88$

$06 / 01 / 89$

(1) $12 / 12 / 84$

$04 / 12 / 89$

$03 / 17 / 89$

$03 / 12 / 87$

$03 / 12 / 87$

$08 / 24 / 84$

$03 / 12 / 87$

$08 / 10 / 89$

$03 / 24 / 87$ 
TABLE E-5. INVENTORY AND STATUS BY TANK

SIMGLE-SHELL TANKS

November 30, 1993

\begin{tabular}{|c|c|c|c|c|c|c|c|c|c|c|c|c|c|c|c|c|c|c|c|}
\hline & TANK ST & TATUS & & & & LIOUID & VOLUME & & & & SOLIDS V & VOLUME & & VOLU & ME DETERMI & INATION & & & \\
\hline \multirow[t]{2}{*}{ TANK } & \multirow[t]{2}{*}{$\begin{array}{l}\text { WASTE } \\
\text { MATERIAL }\end{array}$} & \multirow[t]{2}{*}{$\begin{array}{c}\text { TANK } \\
\text { INTEGRITY }\end{array}$} & \multirow[t]{2}{*}{$\begin{array}{l}\text { STABIL/ } \\
\text { ISOLATION } \\
\text { STATUS }\end{array}$} & $\begin{array}{r}\text { TOTAL } \\
\text { WASTE } \\
\text { (Kgal) }\end{array}$ & $\begin{array}{l}\text { SUPER- } \\
\text { MATANT } \\
\text { LIOUID } \\
\text { (Kgal) }\end{array}$ & $\begin{array}{l}\text { DRAIN- } \\
\text { ABLE } \\
\text { INTER- } \\
\text { STIT. } \\
\text { (Kgal) }\end{array}$ & $\begin{array}{l}\text { PUMPED } \\
\text { THIS } \\
\text { MONTH } \\
\text { (Kgal) }\end{array}$ & $\begin{array}{l}\text { TOTAL } \\
\text { PUMPED } \\
\text { (Kgal) }\end{array}$ & $\begin{array}{l}\text { DRAIN- } \\
\text { ABLE } \\
\text { LIQUID } \\
\text { REMAIN } \\
\text { (Kgal) }\end{array}$ & $\begin{array}{l}\text { PUMP- } \\
\text { ABLE } \\
\text { LIQUIO } \\
\text { REMAIN } \\
\text { (Kgal) }\end{array}$ & $\begin{array}{l}\text { SLUDGE } \\
\text { (Kgal) }\end{array}$ & $\begin{array}{l}\text { SALTCAKE } \\
\text { (Kgal) }\end{array}$ & $\begin{array}{l}\text { LIQUIOS } \\
\text { VOLUME } \\
\text { METHOD }\end{array}$ & $\begin{array}{l}\text { SOLIOS } \\
\text { VOLLME } \\
\text { METHOD }\end{array}$ & $\begin{array}{l}\text { SOLIDS } \\
\text { VOLUME } \\
\text { UPDATE }\end{array}$ & $\begin{array}{l}\text { SOLIOS } \\
\text { UPDATE } \\
\text { SOURCE } \\
\text { SEE } \\
\text { FOOTNOTE }\end{array}$ & $\begin{array}{l}\text { LAST } \\
\text { PHOTO } \\
\text { DATE }\end{array}$ & $\begin{array}{l}\text { CHG } \\
\text { SINCE } \\
\text { LAST } \\
\text { MNTHLY } \\
\text { REPORT }\end{array}$ & \\
\hline & & & & & & $+++++t$ & SX FARM & STATUS & $+++++t$ & & & & & & & & & & \\
\hline $5 x-101$ & DC & SOUND & /PI & 456 & 1 & 145 & 0.0 & 0.0 & 146 & 124 & 112 & 343 & $\mathbf{P}$ & FP & $04 / 28 / 82$ & & $03 / 10 / 89$ & & \\
\hline $5 x-102$ & DSSF & SOUND & /PI & 543 & 0 & 183 & 0.0 & 0.0 & 183 & 177 & 117 & 426 & $\mathbf{P}$ & $\mathbf{M}$ & $04 / 28 / 82$ & & $01 / 07 / 88$ & & \\
\hline$n^{5 x-103}$ & MCPLX & SOUND & $/ \mathrm{PI}$ & 652 & 1 & 232 & 0.0 & 0.0 & 233 & 211 & 115 & 536 & $\mathbf{F}$ & $\mathbf{s}$ & $07 / 15 / 91$ & & $12 / 17 / 87$ & & $m$ \\
\hline I. $5 x-104$ & DSSF & ASMD LKR & /PI & 614 & 0 & 201 & 0.0 & 113.2 & 201 & 195 & 136 & 478 & $\mathbf{F}$ & $\mathbf{s}$ & $07 / 07 / 89$ & & $09 / 08 / 88$ & & 1 \\
\hline f $5 x-105$ & DSSF & SOUND & /PI & 683 & 0 & 261 & 0.0 & 0.0 & 261 & 238 & 73 & 610 & $\mathbf{P}$ & $\mathbf{F}$ & $04 / 28 / 82$ & & $06 / 15 / 88$ & & \\
\hline $5 x-106$ & NCPLX & SOUND & /PI & 538 & 61 & 194 & 0.0 & 0.0 & 255 & 233 & 12 & 465 & $\mathbf{F}$ & PS & $10 / 28 / 80$ & & $06 / 01 / 89$ & & \\
\hline $5 x-107$ & NCPLX & ASMD LKR & IS/IP & 104 & 0 & 5 & 0.0 & 0.0 & 5 & 0 & 104 & 0 & $\mathbf{P}$ & $M$ & $04 / 28 / 82$ & & $03 / 06 / 87$ & & \\
\hline $5 x-108$ & NCPLX & ASMD LKR & IS/IP & 115 & 0 & 6 & 0.0 & 0.0 & 6 & 0 & 115 & 0 & $\mathbf{P}$ & $M$ & $04 / 28 / 82$ & & $03 / 06 / 87$ & & \\
\hline $5 x-109$ & MCPLX & ASHD LKR & IS/IP & 250 & 0 & 10 & 0.0 & 0.0 & 10 & 0 & 0 & 250 & $\mathbf{P}$ & $M$ & $10 / 05 / 93$ & & $05 / 21 / 86$ & & \\
\hline $5 x-110$ & NCPLX & ASMD LKR & $1 S / I P$ & 62 & 0 & 0 & 0.0 & 0.0 & 0 & 0 & 62 & 0 & $\mathbf{M}$ & PS & $10 / 06 / 76$ & & $02 / 20 / 87$ & & \\
\hline sx-111 & HCPLX & ASHD LKR & IS/IP & 125 & 0 & 7 & 0.0 & 0.0 & 7 & 0 & 125 & 0 & $M$ & PS & $05 / 31 / 74$ & & $03 / 10 / 87$ & & \\
\hline $5 x-112$ & MCPLX & ASMD LKR & IS/IP & 92 & 0 & 3 & 0.0 & 0.0 & 3 & 0 & 92 & 0 & $\mathbf{P}$ & $M$ & $04 / 28 / 82$ & & $03 / 10 / 87$ & & \\
\hline $5 x-113$ & NCPLX & ASMD LKR & IS/IP & 26 & 0 & 0 & 0.0 & 0.0 & 0 & 0 & 26 & 0 & $\mathbf{P}$ & $M$ & $04 / 28 / 82$ & & $03 / 18 / 88$ & & \\
\hline $5 x-114$ & NCPLX & ASMD LKR & IS/IP & 181 & 0 & 14 & 0.0 & 0.0 & 14 & 0 & 181 & o & $\mathbf{P}$ & $M$ & $04 / 28 / 82$ & & $02 / 26 / 87$ & & \\
\hline $5 x-115$ & NCPLX & ASMD LKR & IS/IP & 12 & 0 & 0 & 0.0 & 0.0 & 0 & 0 & 12 & 0 & $\mathbf{P}$ & $M$ & $04 / 28 / 82$ & & $03 / 31 / 88$ & & \\
\hline 15 SINC & IGLE-SHELL & TANKS & TOTALS: & 4453 & 63 & 1261 & 0.0 & 113.2 & 1324 & 1178 & 1282 & 3108 & & & & & & & \\
\hline
\end{tabular}


TABLE E-5. INVENTORY AND STATUS BY TANK SINGLE-SHELL. TANKS November 30, 1993

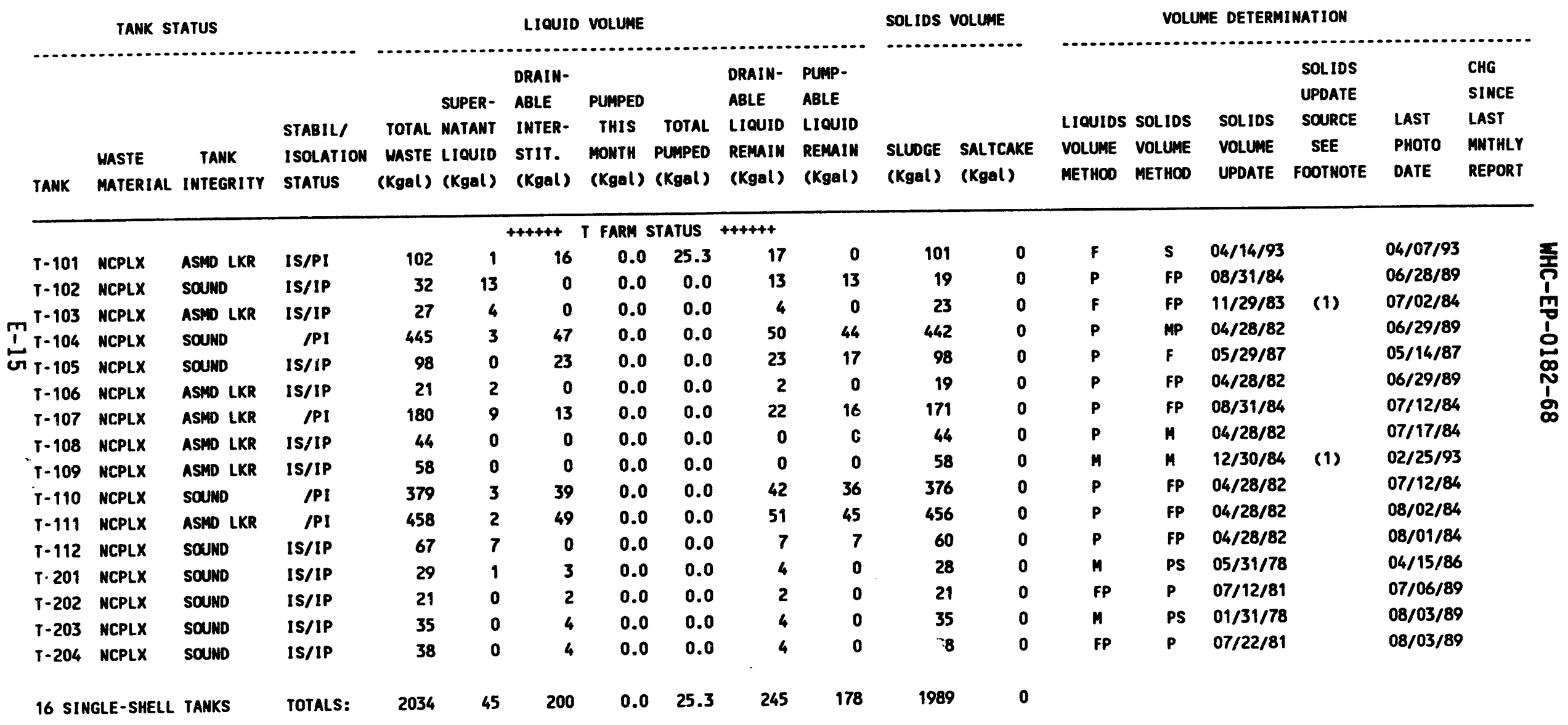


TABLE E-5. INVENTORY AND STATUS BY TANK

SIMGLE-SHELL TANKS

Novenber 30, 1993

\begin{tabular}{|c|c|c|c|c|c|c|c|c|c|c|c|c|c|c|c|c|c|c|c|}
\hline & TANK ST & TATUS & \multirow[b]{2}{*}{$\begin{array}{l}\text { STABIL/ } \\
\text { ISOLATION } \\
\text { STATUS }\end{array}$} & \multicolumn{7}{|c|}{ LIOUTD VOLUME } & \multicolumn{2}{|c|}{ SOLIDS VOLUME } & \multicolumn{5}{|c|}{ VOLUME DETERMINATION } & \multirow{2}{*}{\multicolumn{2}{|c|}{$\begin{array}{l}\text { CHG } \\
\text { SINCE } \\
\text { LAST } \\
\text { MHTHLY } \\
\text { REPORT }\end{array}$}} \\
\hline \multirow[t]{2}{*}{ TANK. } & \multirow[t]{2}{*}{$\begin{array}{l}\text { WASTE } \\
\text { MATERIAL }\end{array}$} & $\begin{array}{c}\text { TANK } \\
\text { INTEGRITY }\end{array}$ & & $\begin{array}{r}\text { TOTAL } \\
\text { WASTE } \\
\text { (Kgal) }\end{array}$ & $\begin{array}{l}\text { SUPER- } \\
\text { NATANT } \\
\text { LIQUID } \\
\text { (Kgal) }\end{array}$ & $\begin{array}{l}\text { DRAIN- } \\
\text { ABLE } \\
\text { INTER- } \\
\text { STIT. } \\
\text { (Kgal) }\end{array}$ & $\begin{array}{l}\text { PUAPED } \\
\text { THIS } \\
\text { MONTH } \\
\text { (Kgal) }\end{array}$ & $\begin{array}{l}\text { TOTAL } \\
\text { PUAPED } \\
\text { (Kgal) }\end{array}$ & $\begin{array}{l}\text { DRAIN- } \\
\text { ABLE } \\
\text { LIQUID } \\
\text { REMAIN } \\
\text { (Kgal) }\end{array}$ & $\begin{array}{l}\text { PUAP- } \\
\text { ABLE } \\
\text { LIQUID } \\
\text { REMAIN } \\
\text { (Kgal) }\end{array}$ & $\begin{array}{l}\text { SLUDGE } \\
\text { (Kgal) }\end{array}$ & $\begin{array}{l}\text { SALTCAKE } \\
\text { (Kgal) }\end{array}$ & $\begin{array}{l}\text { LICUIDS } \\
\text { VOLUNE } \\
\text { METHOD }\end{array}$ & $\begin{array}{l}\text { SOLIDS } \\
\text { VOLUME } \\
\text { METHOD }\end{array}$ & $\begin{array}{l}\text { SOLIDS } \\
\text { VOLUME } \\
\text { UPDATE }\end{array}$ & $\begin{array}{l}\text { SOLIDS } \\
\text { UPDATE } \\
\text { SOURCE } \\
\text { SEE } \\
\text { FOOTHOTE }\end{array}$ & $\begin{array}{l}\text { LAST } \\
\text { PHOTO } \\
\text { DATE }\end{array}$ & & \\
\hline & & & & & & ++++++ & TX FARM & Status & t+t+t+ & & & & & & & & & & \\
\hline$T X-101$ & MCPLX & SOUND & IS/IP & 87 & 3 & 2 & 0.0 & 0.0 & 5 & 0 & 84 & 0 & $\mathbf{F}$ & $\mathbf{P}$ & $02 / 02 / 84$ & (1) & $10 / 24 / 85$ & & \\
\hline$T X-102$ & NCPLX & SOUND & $15 / 1 P$ & 113 & 0 & 22 & 0.0 & 94.4 & 22 & 0 & 0 & 113 & M & $\mathbf{s}$ & $08 / 31 / 84$ & & $10 / 31 / 85$ & & $\frac{1}{\rho}$ \\
\hline$T x-103$ & NCPLX & SOUND & IS/IP & 157 & 0 & 15 & 0.0 & 68.3 & 15 & 0 & 157 & 0 & $\mathbf{F}$ & $\mathbf{s}$ & $08 / 14 / 80$ & & $10 / 31 / 85$ & & $m$ \\
\hline$T X-104$ & NCPLX & SOUND & IS/IP & 65 & 1 & 14 & 0.0 & 3.6 & 15 & 0 & 0 & 64 & $\mathbf{F}$ & FP & $04 / 06 / 84$ & & $10 / 16 / 84$ & & \\
\hline$T X-105$ & NCPLX & ASWD LKR & IS/IP & 609 & 0 & 20 & 0.0 & 121.5 & 20 & 0 & 0 & 609 & M & PS & $08 / 22 / 77$ & & $10 / 24 / 89$ & & \\
\hline$T X-106$ & MCPLX & SOUND & IS/IP & 453 & 0 & 10 & 0.0 & 134.6 & 10 & 0 & 0 & 453 & $\mathbf{m}$ & $\mathbf{s}$ & $08 / 29 / 77$ & & $10 / 31 / 85$ & & \\
\hline$T X-107$ & NCPLXX & ASMD LKR & IS/IP & 36 & 1 & 1 & 0.0 & 0.0 & 2 & 0 & 0 & 35 & FP & FP & $01 / 20 / 84$ & (1) & $10 / 31 / 85$ & & \\
\hline$T X-108$ & NCPLX & SOUND & $1 S / 1 P$ & 134 & 0 & 0 & 0.0 & 13.7 & 0 & 0 & 0 & 134 & $\mathbf{P}$ & FP & $05 / 30 / 83$ & & $09 / 12 / 89$ & & \\
\hline$T X-109$ & NCPLX & SOUND & IS/IP & 384 & 0 & 10 & 0.0 & 72.3 & 10 & 0 & 0 & 384 & $\mathbf{F}$ & PS & $05 / 30 / 83$ & & $10 / 24 / 89$ & & \\
\hline $7 x-110$ & NCPLXX & ASIM LKR & IS/IP & 462 & 0 & 15 & 0.0 & 115.1 & 15 & 0 & 0 & 462 & $M$ & PS & $05 / 30 / 83$ & & $10 / 24 / 89$ & & \\
\hline$T X-111$ & NCPLX & SOUND & $15 / I P$ & 370 & 0 & 9 & 0.0 & 98.4 & 9 & 0 & 0 & 370 & $M$ & PS & $07 / 26 / 77$ & & $09 / 12 / 89$ & & \\
\hline$T X-112$ & NCPLX & souno & IS/IP & 649 & 0 & 24 & 0.0 & 94.0 & 24 & 0 & 0 & 649 & $\mathbf{P}$ & PS & $05 / 30 / 83$ & & $11 / 19 / 87$ & & \\
\hline$T x-113$ & HCPLX & ASMD LKR & IS/IP & 607 & 0 & 16 & 0.0 & 19.2 & 16 & 0 & 0 & 607 & $M$ & PS & $05 / 30 / 83$ & & $04 / 11 / 83$ & & \\
\hline$T x-114$ & NCPLX & ASID LKR & IS/IP & 535 & 0 & 15 & 0.0 & 104.3 & 15 & 0 & 0 & 535 & $M$ & PS & $05 / 30 / 83$ & & $04 / 11 / 83$ & & \\
\hline$T X-115$ & NCPLX & ASMD LKR & IS/IP & 640 & 0 & 19 & 0.0 & 99.1 & 19 & 0 & 0 & 640 & $M$ & $\mathbf{s}$ & $03 / 25 / 83$ & & $06 / 15 / 88$ & & \\
\hline$T x-116$ & NCPLX & ASMD LKR & IS/IP & 631 & 0 & 23 & 0.0 & 23.8 & 23 & 0 & 0 & 631 & $M$ & PS & $03 / 31 / 72$ & & $10 / 17 / 89$ & & \\
\hline$T X-117$ & NCPLX & ASMD LKR & IS/IP & 626 & 0 & 8 & 0.0 & 54.3 & 8 & 0 & 0 & 626 & $M$ & PS & $12 / 31 / 71$ & & $04 / 11 / 83$ & & \\
\hline$T x-118$ & MCPLX & SOUND & IS/IP & 347 & 0 & 27 & 0.0 & 89.1 & 27 & 0 & 0 & 347 & $\mathbf{F}$ & $\mathbf{s}$ & $11 / 17 / 80$ & & $12 / 19 / 79$ & & \\
\hline 18 SINC & GLE-SHELL & TANKS & TOTALS: & 6905 & 5 & 250 & 0.0 & 1205.7 & 255 & 0 & 241 & 6659 & & & & & & & \\
\hline
\end{tabular}


TABLE E-5. INVENTORY AND STATUS BY TANK

SINGLE-SHELL TANKS

November 30, 1993

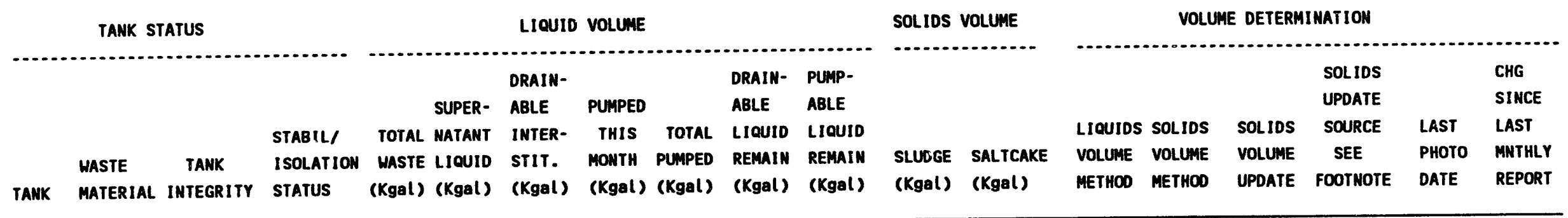

\begin{tabular}{|c|c|c|c|c|c|c|c|c|c|c|c|c|c|c|c|c|c|}
\hline & & & & & & +++ T & FARM & TATUS & +t++++t & & & & & & & & \\
\hline TY-101 & NCPLX & ASMD LKR & IS/IP & 118 & 0 & 0 & 0.0 & 8.2 & 0 & 0 & 118 & 0 & $\mathbf{P}$ & $\mathbf{F}$ & $04 / 28 / 82$ & & $08 / 22 / 89$ \\
\hline$T Y-102$ & NCPLX & SOUND & IS/IP & 64 & 0 & 14 & 0.0 & 6.6 & 14 & 0 & 0 & 64 & $\mathbf{P}$ & FP & $06 / 28 / 82$ & & $07 / 07 / 87$ \\
\hline$T Y-103$ & MCPLX & ASMD LKR & IS/IP & 162 & 0 & 5 & 0.0 & 11.5 & 5 & 0 & 162 & 0 & $\mathbf{P}$ & FP & $07 / 09 / 82$ & & $08 / 22 / 89$ \\
\hline$T Y-104$ & NCPLX & ASMD LKR & IS/IP & 46 & 3 & 12 & 0.0 & 0.0 & 15 & 0 & 43 & 0 & $\mathbf{P}$ & FP & $06 / 27 / 90$ & (1) & $11 / 03 / 87$ \\
\hline$T Y-105$ & NCPLX & ASMD LKR & $1 S / 1 P$ & 231 & 0 & 0 & 0.0 & 3.6 & 0 & 0 & 231 & 0 & $P$ & $M$ & $04 / 28 / 82$ & & $09 / 07 / 89$ \\
\hline$T Y-106$ & NCPLX & ASMD LKR & $1 S / 1 P$ & 17 & 0 & 0 & 0.0 & 0.0 & 0 & 0 & 17 & 0 & $\mathbf{P}$ & $M$ & $04 / 28 / 82$ & & $08 / 22 / 89$ \\
\hline 6 SINGL & LE-SHELL & TANKS & TOTALS: & 638 & 3 & 31 & 0.0 & 29.9 & 34 & 0 & 571 & 64 & & & & & \\
\hline & & & & & & $+++U$ & FARM S & ATUS + & t+t+t+ & & & & & & & & \\
\hline U-101 & NCPLX & ASMD LKR & IS/IP & 25 & 3 & 0 & 0.0 & 0.0 & 3 & 0 & 22 & 0 & $P$ & MP & $04 / 28 / 82$ & & $06 / 19 / 79$ \\
\hline$U-102$ & NCPLX & SOUND & /PI & 374 & 18 & 126 & 0.0 & 0.0 & 144 & 122 & 43 & 313 & P & MP & $04 / 28 / 82$ & & $06 / 08 / 89$ \\
\hline$U-103$ & NCPLX & SOUND & /PI & 468 & 13 & 176 & 0.0 & 0.0 & 189 & 166 & 32 & 423 & $\mathbf{P}$ & FP & $04 / 28 / 82$ & & $09 / 13 / 88$ \\
\hline$U-104$ & NCPLX & ASMD LKR & IS/IP & 122 & 0 & 7 & 0.0 & 0.0 & 7 & 0 & 122 & 0 & $\mathbf{P}$ & MP & $04 / 28 / 82$ & & $08 / 10 / 89$ \\
\hline$U-105$ & NCPLX & SOUND & /PI & 418 & 37 & 142 & 0.0 & 0.0 & 179 & 157 & 32 & 349 & $\mathbf{F M}$ & PS & $09 / 30 / 78$ & & $07 / 07 / 88$ \\
\hline$U-106$ & NCPLX & SOUND & /PI & 226 & 15 & 68 & 0.0 & 0.0 & 83 & 61 & 26 & 185 & $\mathbf{F}$ & PS & $12 / 30 / 83$ & & $07 / 07 / 88$ \\
\hline$U-107$ & DSSF & SOUND & /PI & 406 & 31 & 147 & 0.0 & 0.0 & 178 & 156 & 15 & 360 & $\mathbf{F}$ & $\mathbf{s}$ & $12 / 30 / 83$ & & $10 / 27 / 88$ \\
\hline$U-108$ & NCPLX & SOUND & /PI & 468 & 24 & 172 & 0.0 & 0.0 & 196 & 174 & 29 & 415 & $F$ & $\mathbf{s}$ & $12 / 30 / 83$ & & $09 / 12 / 84$ \\
\hline$U-109$ & NCPLX & SOUND & /PI & 463 & 19 & 163 & 0.0 & 0.0 & 182 & 160 & 48 & 396 & $\mathbf{F}$ & $F$ & $11 / 13 / 77$ & & $07 / 07 / 88$ \\
\hline$u-110$ & NCPLX & ASMD LKR & IS/PI & 186 & 0 & 15 & 0.0 & 0.0 & 15 & 9 & 186 & 0 & $M$ & $M$ & $12 / 30 / 84$ & (1) & $12 / 11 / 84$ \\
\hline U-111 & DSSF & SOUND & /PI & 329 & 0 & 122 & 0.0 & 0.0 & 122 & 99 & 26 & 303 & PS & FPS & $04 / 28 / 82$ & & $06 / 23 / 88$ \\
\hline$U-112$ & NCPLX & ASMD LKR & IS/IP & 49 & 4 & 0 & 0.0 & 0.0 & 4 & 0 & 45 & 0 & $\mathbf{P}$ & MP & $02 / 10 / 84$ & (1) & $08 / 03 / 89$ \\
\hline
\end{tabular}


TABLE E-5. INVENTORY AND STATUS BY TANK SINGLE-SHELL TANKS November 30, 1993

TANK STATUS

UASTE TANK

TANK

ISOLATION

TANK MATERIAL INTEGRITY STATUS

U-201 NCPLX SOUND

U-202 NCPLX SOUND

$U-203$ NCPLX SOUND

U-204 HCPLX SOUND

$\begin{array}{lll}\text { IS/IP } & 5 & 1 \\ 1 S / 1 P & 5 & 1 \\ 15 / 1 P & 3 & 1 \\ \text { IS } / 1 P & 3 & 1\end{array}$

LIOUID VOLUME

DRAIN-

SUPER- ABLE PUMPED ABLE ABLE

I 16 SINGLE-SHELL TANKS

$\infty$

GRAND TOTAL

$\begin{array}{llllllll}\text { TOTALS: } & 3550 & 168 & 1138 & 0.0 & 0.0 & 1306 & 1104\end{array}$
SOLIDS VOLUME

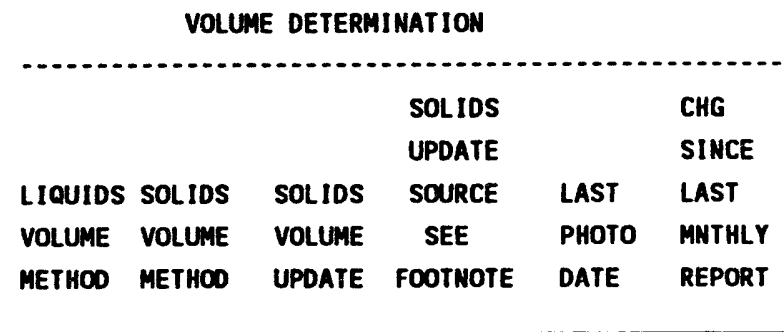

\begin{tabular}{lllll}
$M$ & $S$ & $08 / 15 / 79$ & $08 / 03 / 89$ \\
$M$ & $S$ & $08 / 15 / 79$ & $08 / 08 / 89$ \\
$M$ & $S$ & $08 / 15 / 79$ & $06 / 13 / 89$ & \\
$M$ & $S$ & $08 / 15 / 79$ & $06 / 13 / 89$ & 5 \\
& & & & \\
& & & & \\
\hline
\end{tabular}

$\begin{array}{lllllllll}36190 & 557 & 6320 & 24 & 3852 & 6877 & 5382 & 12214 & 23419 \\ & & & & & & & & \end{array}$

NOTES: +/- 1K gal differences are the result of rounding

Total Waste is calculated as the sum of Sludge and Saltcake plus Supernate.

The category "Interim Isolated" (II) was changed to "Intrusion Prevention" (IP) in June 1993. See section C. "Tank and Equipment Code and Status Definitions"

(1) HHC-SD-RE-TI-178 SST STABILIZATION RECORD, latest revision

(2) TANK FARMS SST ENGINEER MONTHLY INPUT (Retained $10 \mathrm{yr}$ in Monthly Sumary Report author's office)

See next page for footnotes in "Chg Since Last Monthly Report" 
TABLE E-5. INVENTORY AND STATUS BY TANK

SIMGLE-SHELL TANKS

November 30, 1993

\begin{tabular}{|c|c|c|c|c|c|c|c|c|c|c|c|c|c|c|c|c|c|c|}
\hline & TANK ST & tatus & & & & LIQUID & VOLUME & & & & SOLIDS & VOLUME & & VOLU & E DETERM & IHATION & & \\
\hline NK & $\begin{array}{l}\text { WASTE } \\
\text { MATERIAL }\end{array}$ & $\begin{array}{c}\text { TANK } \\
\text { INTEGRITY }\end{array}$ & $\begin{array}{l}\text { STABIL/ } \\
\text { ISOLATION } \\
\text { STATUS }\end{array}$ & $\begin{array}{l}\text { TOTAL } \\
\text { HASTE } \\
\text { (Kgal) }\end{array}$ & $\begin{array}{l}\text { SUPER- } \\
\text { MATANT } \\
\text { LIQUID } \\
\text { (Kgal) }\end{array}$ & $\begin{array}{l}\text { DRAIN- } \\
\text { ABLE } \\
\text { INTER- } \\
\text { STIT. } \\
\text { (Kgal) }\end{array}$ & $\begin{array}{l}\text { PUNPED } \\
\text { THIS } \\
\text { MONTH } \\
\text { (Kgal) }\end{array}$ & $\begin{array}{l}\text { TOTAL } \\
\text { PUMPED } \\
\text { (Kgal) }\end{array}$ & $\begin{array}{l}\text { DRAIN- } \\
\text { ABLE } \\
\text { LIQUID } \\
\text { REMAIN } \\
\text { (Kgal) }\end{array}$ & $\begin{array}{l}\text { PUMP- } \\
\text { ABLE } \\
\text { LIQUID } \\
\text { REMAIN } \\
\text { (Kgal) }\end{array}$ & $\begin{array}{l}\text { SLUDGE } \\
\text { (Kgal) }\end{array}$ & $\begin{array}{l}\text { SALTCAKE } \\
\text { (Kgal) }\end{array}$ & $\begin{array}{l}\text { LIQUIDS } \\
\text { VOLUME } \\
\text { METHOD }\end{array}$ & $\begin{array}{l}\text { SOLIDS } \\
\text { VOLUME } \\
\text { METHOD }\end{array}$ & $\begin{array}{l}\text { SOLIDS } \\
\text { VOLUME } \\
\text { UPDATE }\end{array}$ & $\begin{array}{l}\text { SOLIDS } \\
\text { UPDATE } \\
\text { SOURCE } \\
\text { SEE } \\
\text { FOOTNOTE }\end{array}$ & $\begin{array}{l}\text { LAST } \\
\text { PHOTO } \\
\text { DATE }\end{array}$ & $\begin{array}{l}\text { CHG } \\
\text { SINCE } \\
\text { LAST } \\
\text { MNTHLY } \\
\text { REPORT }\end{array}$ \\
\hline
\end{tabular}

Footnotes:

(a) BX-111 - Following information from Single-Shell Tanks Cognizant Engineer

Pumping began October 22, 1993

$\underset{1}{T}$ Total waste (Supernatant + Solids) $-211.0 \mathrm{kgal}$

๘) Supernatant - $0 \mathrm{Kgal}$

Drainable Interstitial - $38.2 \mathrm{Kgal}$

Pumped this Month - $24 \mathrm{Kgal}$

Total Pumped - $31 \mathrm{Kgal}$

Drainable Liquid Remaining - $38.2 \mathrm{kgal}$

Pumpable Liquid Remaining - $14.9 \mathrm{Kgal}$

sludge - $68.0 \mathrm{Kgal}$

Saltcake - $143.0 \mathrm{Kgal}$ 
WHC-EP-0182-68

This page intentionally left blank 
WHC-EP-0182-68

\section{APPENDIX F}

PERFORMANCE SUMMARY 
WHC-EP-0182-68

This page intentionally left blank. 
TABLE F-1. PERFORMANCE SUMMARY (Sheet 1 of 3)

WASTE VOLUMES (Kgallons)

November 30, 1993

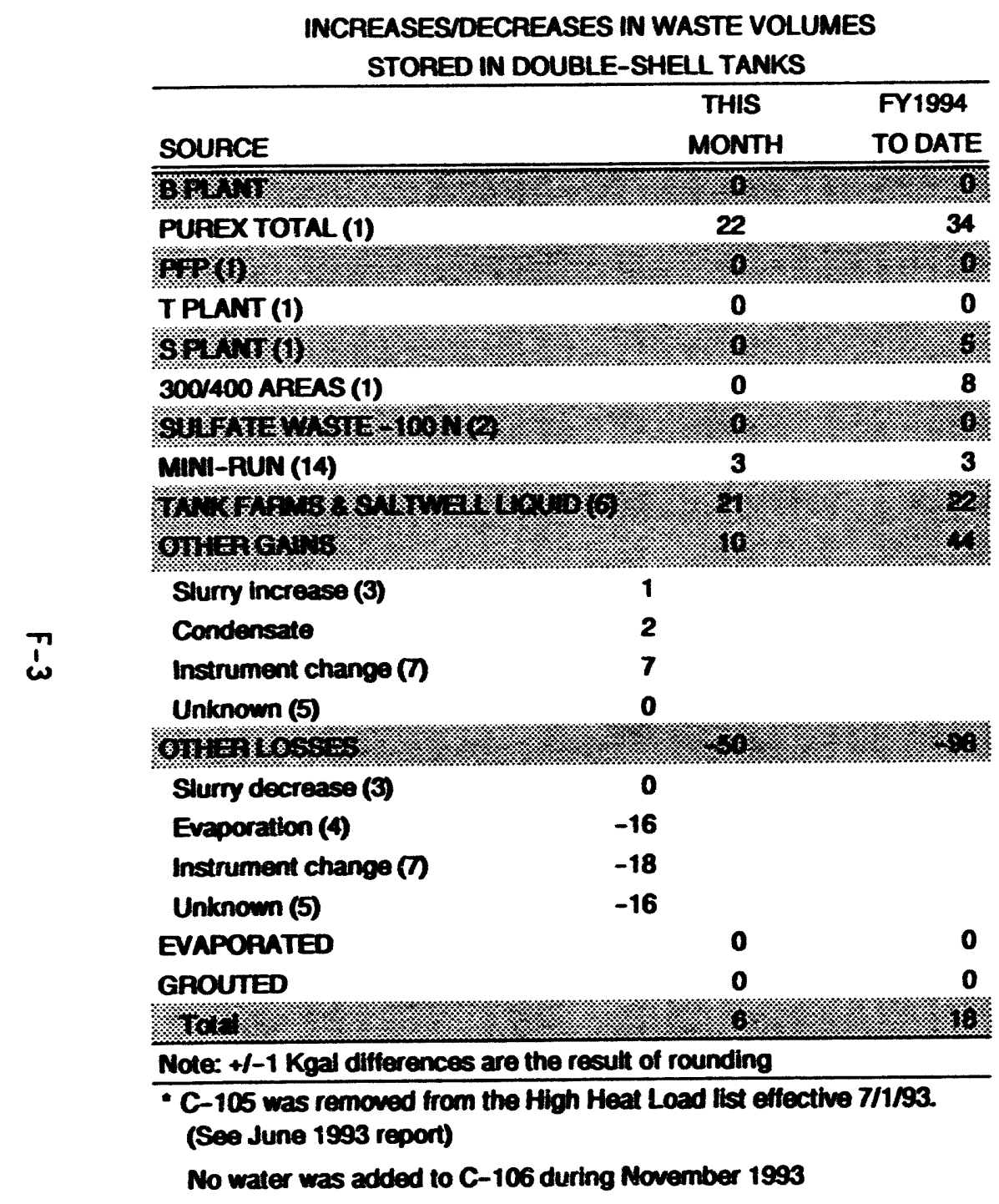

\begin{tabular}{|c|c|c|c|}
\hline \multicolumn{4}{|c|}{$\begin{array}{l}\text { INCREASESIDECREASES IN WASTE VOLUMES } \\
\text { STORED IN SINGLE-SHELL TANKS }\end{array}$} \\
\hline & & THIS & FY1994 \\
\hline SOURCE & & MONTH & TO DATE \\
\hline \multirow[t]{2}{*}{ 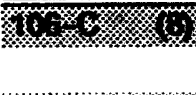 } & $\mathrm{g}^{\mathrm{x}}$ & 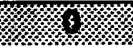 & 蠜 \\
\hline & Losses & -8 & -13 \\
\hline 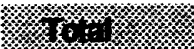 & & 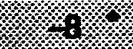 & s. \\
\hline
\end{tabular}

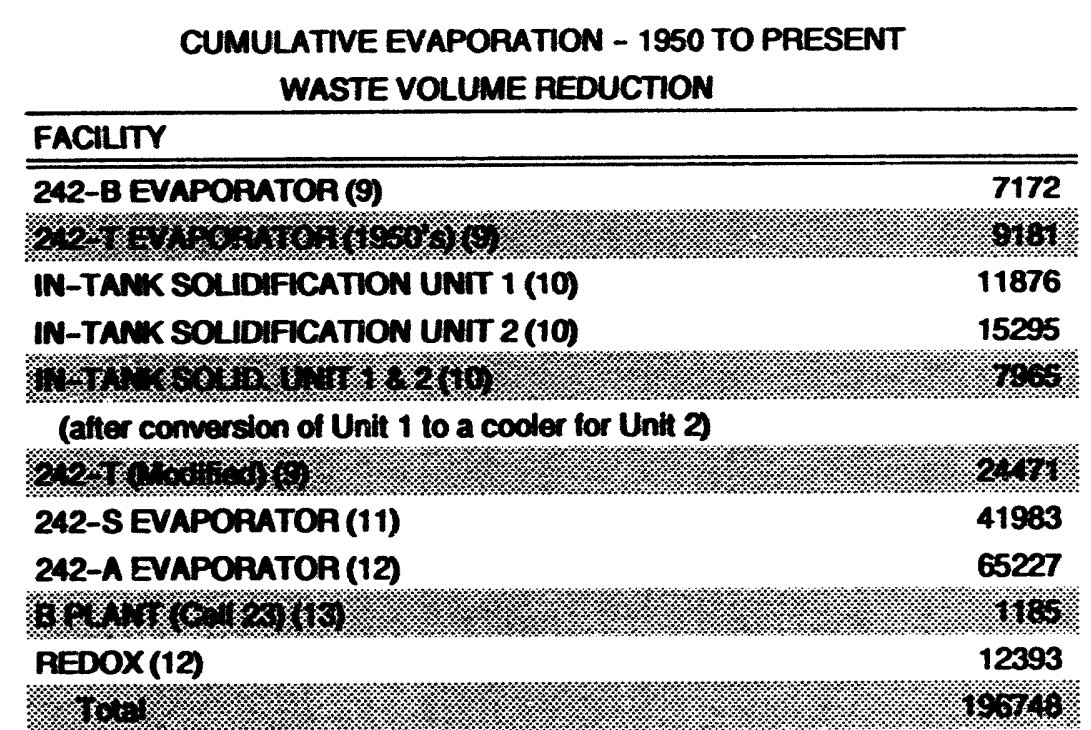

TOTAL THROUGHPUT

\begin{tabular}{ll} 
TOTAL THROUGHPUT \\
\hline FACILTT \\
\hline \hline 242-A EVAPORATOA (12) & 182437 \\
242-S EVAPORATOR(11) & 134587 \\
3 &
\end{tabular}

Footnotes: See Next Page 
WHC-EP-0182-68

TABLE F-1. PERFORMANCE SUMMARY

(Sheet 2 of 2)

Footnotes:

INCREASES/DECREASES IN HASTE VOLUMES

(1) Including Flush

(2) Sulfate waste is generated from ion exchange backflushing and sand filter clean out, resulting in sulfate waste $\left(\mathrm{Na}_{2} \mathrm{SO}_{4}\right)$.

(3) Slurry increase/growth is caused by gas generation within the waste. The gas which is trapped in the waste exponds in the tenk causing the surface level and volume to increase. Slurry decrease results from the periodic release of gas in the waste.

(4) Aging waste tanks

(5) Unknown waste gains or losses may be the result of rounding calculations, clean water slowly leaking through a valve, changes in levels (expansion/contraction) because of amblent temperature changes, different measuring devices being used by Tank farm operators, transfers taking place during the end of the month, Tank Farm activities such as miscellaneous water additions not associated with facility waste generation, or the addition of water which is added to aging waste tanks and then evaporated off.

(6) Includes Tank Farms miscellaneous flushes (flushes are used to "clean out" pipel ines and reduce personnel exposure, reduce potential for waste incompatibility, prevent line plugging, and reduce waste content of potential spills or leaks), and saltwell liquid, which results from pumping of single-shell tanks to double-shell tanks.

(7) Liquid level masurement instrument chenges from the autometic fic to manual tape (and vice versa) result in unusual gains or losses because the manual tape may rest on an uneven crust surface giving a different reading from that of the automatic FIC. These instrument changes ore made when the automatic FIC is out of service and the reading from the manual tape is used for reporting purposes. The reported reading reverts back to the automatic FIC when it is repaired.

(8) Water is periodically added 106-C to provide evaporative cooling. Losses due to evaporation are calculated assuming all losses are evaporative losses. Some drywells are monitored weekly and some are monitored every two weeks on tank 106-C. If there are any indications of a leak from this tank, the assumption that all losses are due to evaporation will be reevaluated.

\section{HASTE VOLUME REDUCTION}

(9) Currently inoperative. These evaporator systems (242-B and 242-T) were installed in 1952 in each of the two operating areas to remove water from the waste, and ran for approximately 4 yr after which both units were shut down. The 242-T Evaporator was reactivated in December 1965, and shut down again in April 1976.

(10) Currently inoperative. These two in-tank solidification (ITS) units provided in-tank heating to promote in-tank boiling or evaporation. The ITs Unit 1 started up March 1965, and ITs Unit 2 started up February 1968. In August 1971, ITS Unit 1 was converted from an evaporator to a cooler for ITS Unit 2. Both units were shut down June 1974.

(11) Currently inoperative. The 242-5 Evaporator-Crystallizer was started up November 1973, and shut down March 1980, when its processing campaign was completed. It is in standby mode with no future mission. This evaporator operates under a vacum, employing evaporative concentration with subsequent crystallization and precipitation of salt crystals.

(12) Currently inoperative. The 242-A Evaporator-Crystallizer was started up March 1977, and shut down April 1989 because of regulatory issues, and has remeined shut down for subsequent upgrading. The projected start-up date is Jenuary 15-17, 1994. This evaporator operates under a vacuum, employing evaporative concentration with subsequent crystallization and precipitation of salt crystals (forming sal tcake).

(13) Currently inoperative. Additional concentration of wastes was completed by using the concentrators at REDOX and B Plant. The REDOX concentrator was used from July 1967 to June 1972, while the B Plant concentrator was used from July 1967 to February 1968.

(14) Waste generated for training and testing purposes prior to Evaporator restart. 
WHC-EP-0182-68

\section{APPENDIX G}

\section{PUMPING RECORD}

\section{LIQUID STATUS AND PUMPABLE LIQUID}

REMAINING IN TANKS 
WHC-EP-0182-68

This page intentionally left blank.

G-2 
TABLE G-1. PUMPING RECORD

(Kgallons)

November 30, 1993

\begin{tabular}{|c|c|c|c|}
\hline \multirow[b]{2}{*}{$\begin{array}{l}\text { TANK } \\
\text { FARMS }\end{array}$} & \multicolumn{2}{|c|}{ November 30, 1993} & \multirow{2}{*}{$\begin{array}{l}\text { CUMULATIVE } \\
\text { TOTAL PUMPED } \\
1979 \text { TO DATE } \\
\end{array}$} \\
\hline & $\begin{array}{c}\text { PUMPED } \\
\text { THIS MONTH } \\
\end{array}$ & $\begin{array}{l}\text { PUMPED FY } \\
\text { TODATE }\end{array}$ & \\
\hline \multicolumn{4}{|l|}{$m$ m. } \\
\hline A & 0.0 & 0.0 & 150.5 \\
\hline $\mathbf{A N}$ & N/A & N/A & N/A \\
\hline $\mathbf{A P}$ & N/A & N/A & N/A \\
\hline AW & N/A & N/A & N/A \\
\hline$A X$ & 0.0 & 0.0 & 13.0 \\
\hline AY & N/A & N/A & N/A \\
\hline $\mathbf{A Z}$ & N/A & N/A & N/A \\
\hline B & 0.0 & 0.0 & 0.0 \\
\hline$B X$ & 24.0 & 31.0 & 98.7 \\
\hline BY & 0.0 & 0.0 & 1387.4 (a) \\
\hline C & 0.0 & 0.0 & 36.8 (b) \\
\hline (1018) & 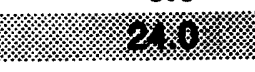 & \% & $16.6 \%$ \\
\hline \multicolumn{4}{|l|}{ 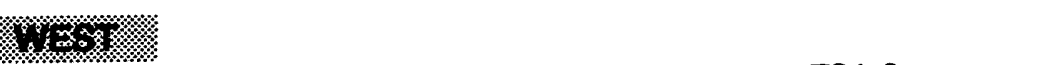 } \\
\hline $\mathbf{S}$ & 0.0 & 0.0 & 791.0 \\
\hline sx & 0.0 & 0.0 & 113.2 \\
\hline SY & N/A & N/A & N/A \\
\hline$T$ & 0.0 & 0.0 & 25.3 \\
\hline $\mathrm{TX}$ & 0.0 & 0.0 & 1205.7 \\
\hline TY & 0.0 & 0.0 & 29.9 \\
\hline $\mathbf{u}$ & 0.0 & 0.0 & 0.0 \\
\hline \% & 806 & 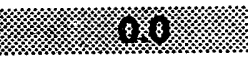 & 286.1 .1 .1$. \\
\hline 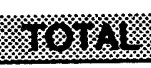 & 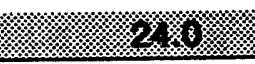 & 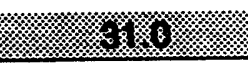 & 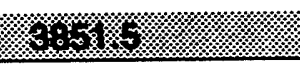 \\
\hline
\end{tabular}

NA $=$ Not Applicable

(a) The total volume pumped was adjusted by the Single-Shell Tanks Engineer to account for the 14\% miscalibration of the constant velocity Iransmitter and the amount of flush water used. DIL DLR and PLA volumes were recalculated, based on the observed porosity in 102 and $109-B Y$.

(b) The total volume pumped was recalculated by the Single-Shell Tanks Engineer based on the surface level readings taken after shutdown of the altwell pumps on lanuary 28, 1992, in 102-C, 107-C and 110-C, and revised again based on recalculation of flush water additions on January 26, 1993. (The total for the tank farm remains the same, the amount pumped varied among the three tanks). 
TABLE G-2. LIQUID STATUS AND PUMPABLE LIQUID REMAINING IN TANKS

WASTE VOLUMES (Kgallons)

November 30, 1993

\begin{tabular}{|c|c|c|c|c|}
\hline $\begin{array}{l}\text { TANK } \\
\text { FARMS }\end{array}$ & $\begin{array}{l}\text { SUPERNATANT } \\
\text { LIQUID }\end{array}$ & $\begin{array}{l}\text { DRAINABLE } \\
\text { INTERSTITIAL } \\
\text { LIQUID } \\
\end{array}$ & $\begin{array}{c}\text { DRAINABLE } \\
\text { LIQUID } \\
\text { REMAINING }\end{array}$ & $\begin{array}{l}\text { PUMPABLE } \\
\text { LIQUID } \\
\text { REMAINING } \\
\end{array}$ \\
\hline \multicolumn{5}{|l|}{ W61" } \\
\hline A & 9 & 441 & 450 & 390 \\
\hline AN & 4542 & 37 & 4579 & N/A \\
\hline $\mathbf{A P}$ & 7279 & 0 & 7279 & N/A \\
\hline AW & 4642 & 159 & 4801 & N/A \\
\hline$A X$ & 3 & 370 & 373 & 304 \\
\hline AY & 1714 & 2 & 1716 & NA \\
\hline AZ & 1755 & 4 & 1759 & N/A \\
\hline B & 15 & 164 & 179 & 80 \\
\hline$B X$ & 31 & 143 & 174 & 104 \\
\hline BY & 0 & 780 & 780 & 598 \\
\hline C & 169 & 143 & 312 & 254 \\
\hline (no & $\% 8 \%$ & 226 & 202189 & 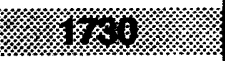 \\
\hline \multicolumn{5}{|l|}{ WEST } \\
\hline $\mathbf{S}$ & 46 & 1399 & 1445 & 1192 \\
\hline sx & 63 & 1261 & 1324 & 1178 \\
\hline SY & 838 & 237 & 1075 & NA \\
\hline$T$ & 45 & 200 & 245 & 178 \\
\hline $\mathrm{TX}$ & 5 & 250 & 255 & 0 \\
\hline TY & 3 & 31 & 34 & 0 \\
\hline $\mathbf{u}$ & 168 & 1138 & 1306 & 1104 \\
\hline mong & 16 & 3 & 8.0 .62 & 8.02. \\
\hline 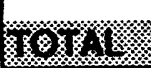 & $20 \%$ & 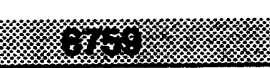 & 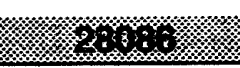 & 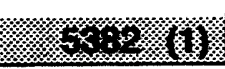 \\
\hline
\end{tabular}

(1) Volume based on 12.5\% (sludge waste) and $45 \%$ (saltcake waste) liquid in solid (porosity) value. This is a conservative (high) estimate.

Note: $+1-1$ Kgal differences are the result of computer rounding

N/A $=$ Not applicable 
WHC-EP-0182-68

\section{APPENDIX H}

CATCH TANKS AND SPECIAL SURVEILLANCE FACILITIES 
WHC-EP-0182-68

This page intentionally left blank. 
TABLE H-1. EAST AND WEST AREA CATCH TANKS AND SPECIAL SURVEILLANCE FACILITIES

ACTIVE - still running transfers through the associated diversion boxes or pipeline encasements

November 30, 1993

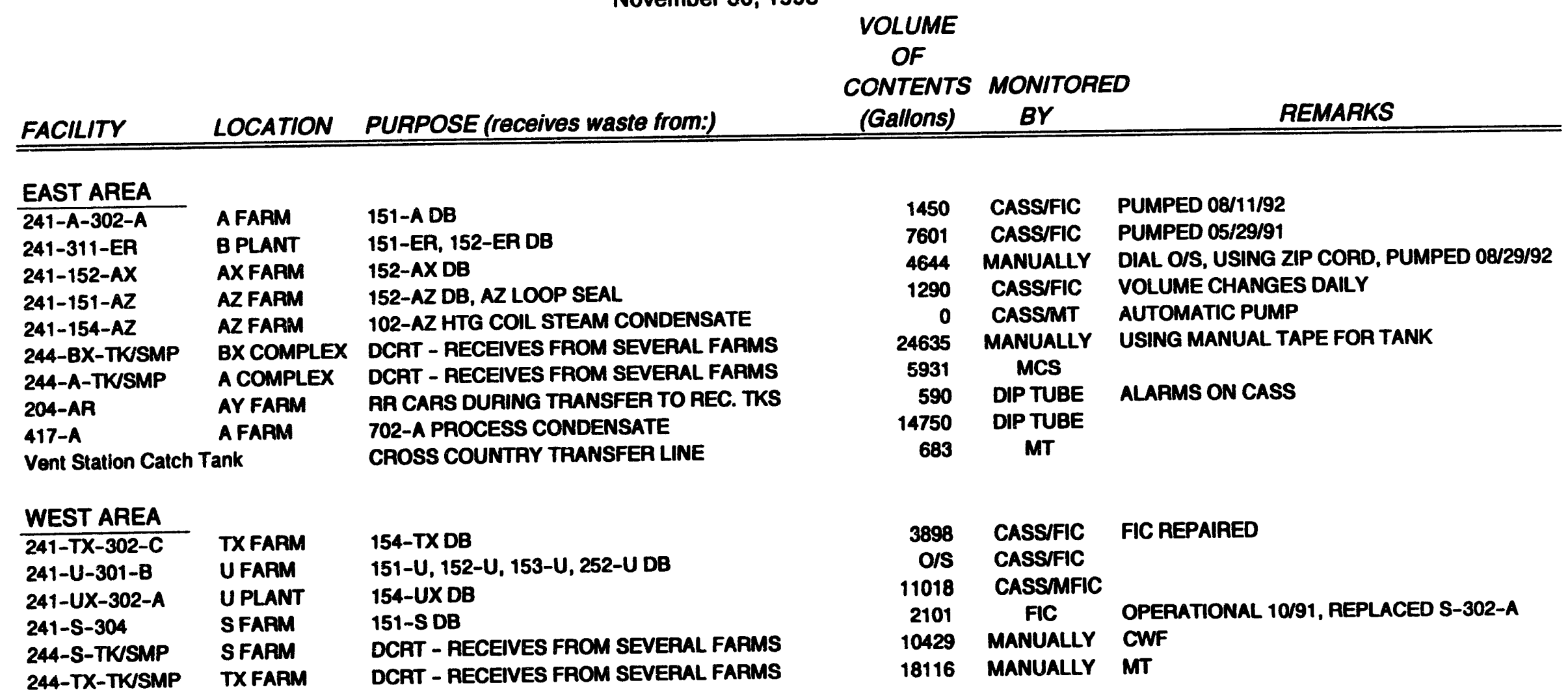

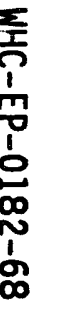

\begin{tabular}{|c|c|}
\hline Total active tacilifies & 16 \\
\hline
\end{tabular}

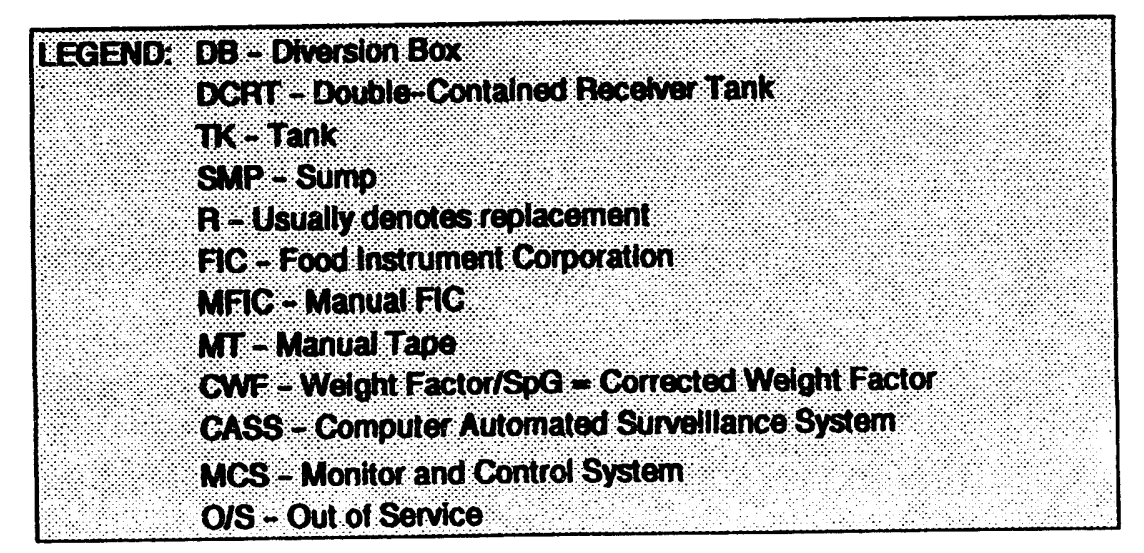


TABLE H-2. EAST AREA CATCH TANKS AND SPECIAL SURVEILLANCE FACILITIES

INACTIVE - no longer receiving waste transfers

November 30, 1993

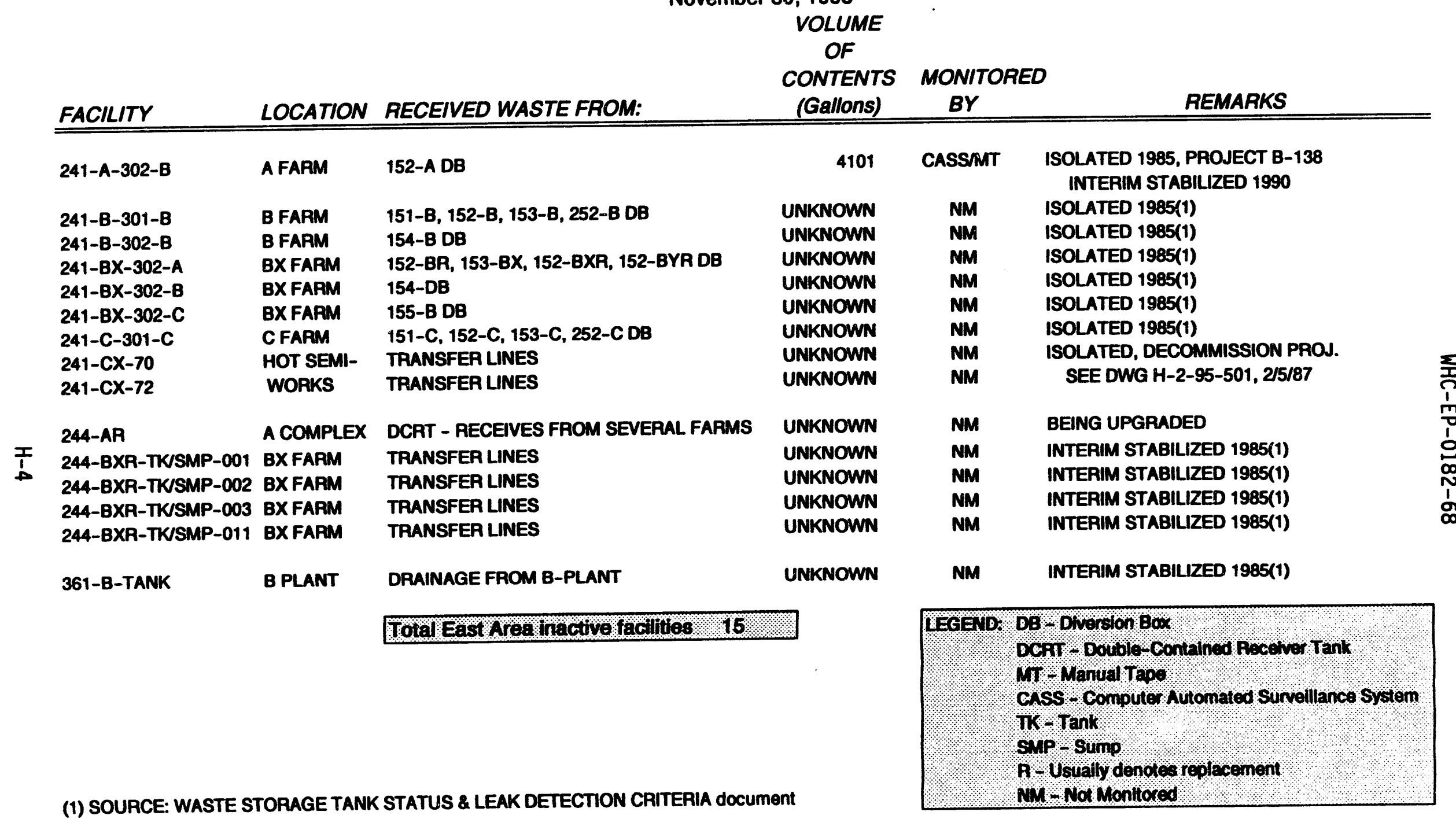




\section{TABLE H-3. WEST AREA CATCH TANKS AND SPECIAL SURVEILLANCE FACILITIES}

INACTIVE - no longer receiving waste transfers

November 30, 1993

$$
\begin{gathered}
\text { VOLUME } \\
\text { OF }
\end{gathered}
$$

CONTENTS

\begin{tabular}{lll} 
FACILITY & LOCATION & RECEIVED WASTE FROM \\
\hline \hline $241-\mathrm{S}-302$ & S FARM & $240-\mathrm{S}-151$ DB \\
$241-\mathrm{S}-302-\mathrm{A}$ & S FARM & $241-\mathrm{S}-151$ DB
\end{tabular}

(Gallons)

BY REMARKS

2276 CASS/FIC * ASSUMED LEAKER EPDA 85-04

- FIC in Intrusion mode Partially filled with grout 2/91, determined

241-S-302-B

241-SX-304(302)

$241-\mathrm{TX}-302$

$241-T X-302-X-B$

$241-T X-302-B$

$241-T Y-302-A$

241-TY-302-B

244-U-TKJSMP

I 244-UR VAULT

U UARM

244-UR-TKISMP-002 U FARM

244-UR-TKISMP-003 U FARM

244-TXR VAULT TXFARM

244-TXR-TK/SMP-001 TXFARM

244-TXR-TKISMP-002 TX FARM

244-TXR-TKSMP-003 TXFAPM

361-T-TANK TPLANT

361-U-TANK U PLANT

S ENCASEMENTS
152-SX TRANSFER BOX, 151-SX DB
153-TX DB
TX ENCASEMENTS
155-TX DB
153-TX DB
TY ENCASEMENTS
DCRT - RECEIVES FROM SEVERAL FARMS
TRANSFER LINES
TRANSFER LINES
TRANSFER LINES
TRANSFER LINES
TRANSFER LINES
TRANSFER LINES
TRANSFER LINES
TRANSFER LINES
DRAINAGE FROM T-PLANT
DRAINAGE FROM U-PLANT

UNKNOWN

UNKNOWN

UNKNOWN

UNKNOWN

1320

UNKNOWN

UNKNOWN

UNKNOWN

UNKNOWN

UNKNOWN

UNKNOWN

UNKNOWN

UNKNOWN

UNKNOWN

UNKNOWN

UNKNOWN

UNKNOWN

UNKNOWN still assumed leaker after leak test

ISOLATED 1985(1)

ISOLATED 1985(1)

ISOLATED 1985(1)

ISOLATED 1985(1)

NEW MT INSTALLED 7/16/93

NM ISOLATED 1985(1)

NM ISOLATED 1985(1)

NM NOT YET IN USE

NM

NM

NM

NM

NM

NM

NM

NM

NM

NM
INTERIM STABILIZED, MT REMOVED 1985(1) INTERIM STABILIZED, MT REMOVED 1985(1) INTERIM STABILIZED, MT REMOVED 1985(1) INTERIM STABILIZED, MT REMOVED 1985(1) INTERIM STABILIZED, MT REMOVED 1984(1) INTERIM STABILIZED, MT REMOVED 1984(1) INTERIM STABILIZED, MT REMOVED 1984(1) INTERIM STABILIZED, MT REMOVED 1984(1) ISOLATED 1985(1) INTERIM STABILIZED, MT REMOVED 1985(1)
Total West Area inactive facilities 20 .

\begin{tabular}{|c|c|}
\hline LEGEND, & 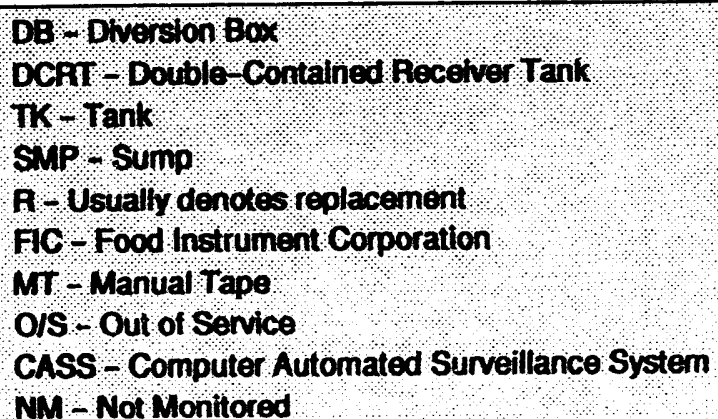 \\
\hline
\end{tabular}


WHC-EP-0182-68

\section{APPENDIX I}

\section{LEAK VOLUME ESTIMATES}


WHC-EP-0182-68

This page intentionally left blank. 


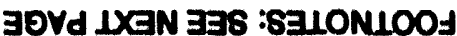

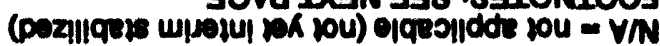

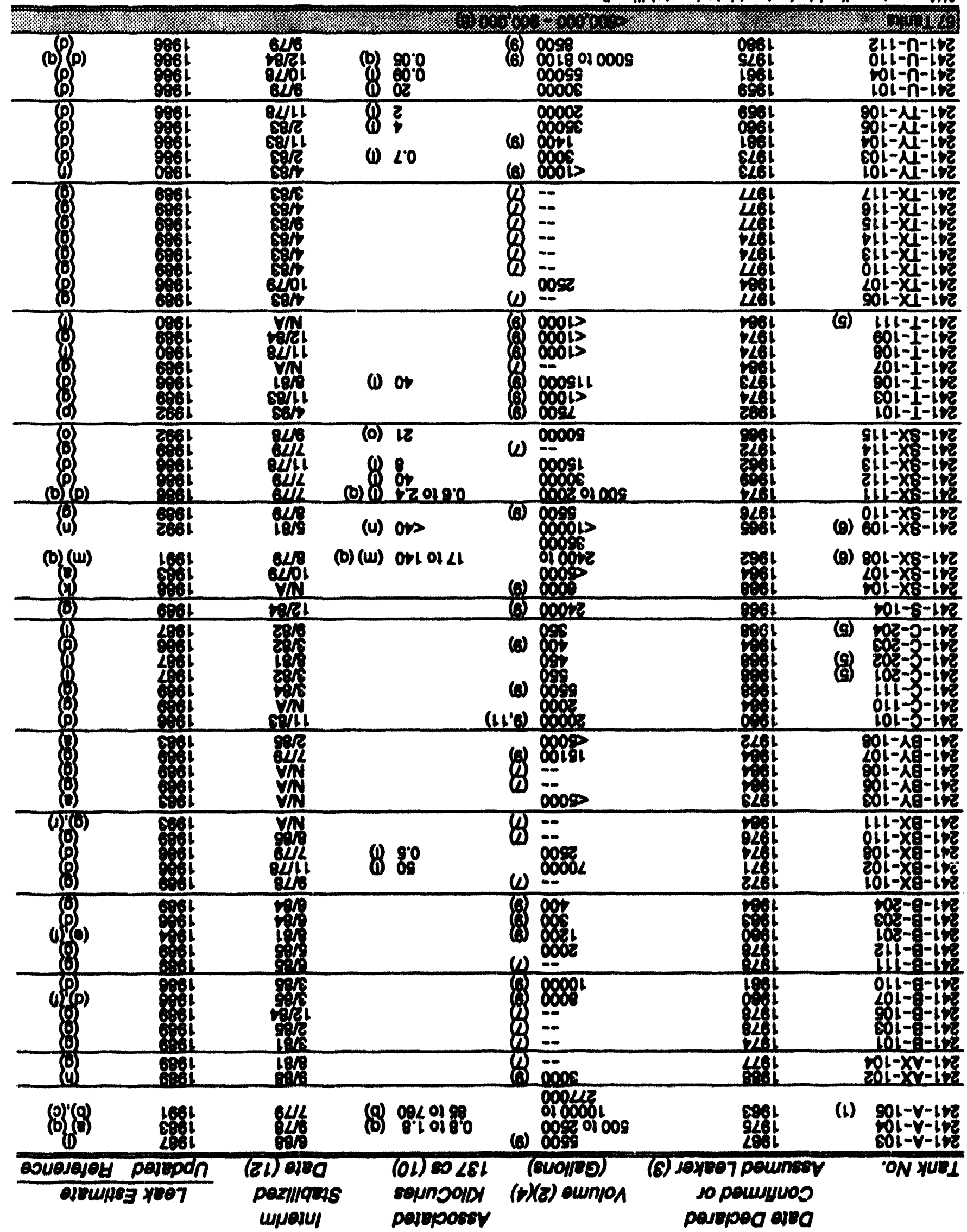

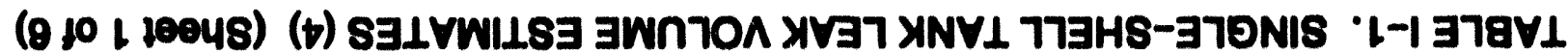




\section{Footnotes:}

(1) Current eatimetes (see roforence b) are that $610 \mathrm{Keal}$ of cooling water was edded to Tank 261-A-105 from November 1970 to December 1976 to ald in oveporut ive coolling. In eccordence with penorroun

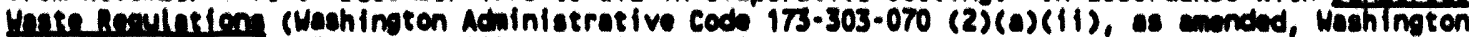
state bepartiment of Ecolooy, 1990, Olymila, Washington), any of this cooline water that hes boen odded and aubsequently leaked from the tenk mot be classiffed as a waste and should be included in the totel leak volum. In Aujust 1991, the leak volum estimote for this tank was updated and noved Into cemplience with the MAC reguletions. Provious estinstes exclued the coolling water leake from the total leak volum cetimites because the waste centent (coneentration) in the cooling water which leaked should be much leas then the orfoinal llquid waste in the tenk (the sludge is rolatively insoluble). The total leak volum estimate in this report $(10 \mathrm{kgal}$ to $277 \mathrm{Kgal})$ ls based on the following (see Reforences).

1. Reforence (b) contoine on eatimate of $5 \mathrm{kgal}$ to $15 \mathrm{kgal}$ for the Initial leak prior to Aloust 1968.

2. Roforence (b) contains en eetinate of $5 \mathrm{kgal}$ to $30 \mathrm{Kgal}$ for the leak wille the tenk was baing sluiced from Aupust 1968 to Moventer 1970.

3. Reference (b) centaine en catingte of $610 \mathrm{kgal}$ of coollin mater added to the tenk tram November 1970 to December 1976 but it wo cetimated that the leakege was anll during this porled. Inis roference conteins the statement "sufficlent hoat was gemoroted in the tenk to eveporate most, and perhepe mearly oll, of this woter." This results in a low estimate of zere gell ions leakace from November 1970 to December 1978.

6. Reference (c) containe en eatimate that 370 to $410 \mathrm{kgal}$ oveporated out of the tenk from November 1970 to Decembor 1970. Subtrectim the minimm eveporatior eutinate from the cooling water edded estimate provides a rense fran 0 to 232 kgol of cool ing woter leakage from November 1970 to December 1970.

Lustinte

Prior to Auguat 196

Auruast 1968 to November 1970

November 1970 to December 1978 Totals

$$
\begin{array}{r}
5,000 \\
5,000 \\
10,000
\end{array}
$$

\section{Himpentime}

$$
\begin{array}{r}
13,000 \\
30,000 \\
27,000 \\
277.000
\end{array}
$$

(2)

(3)

These leak volum estimetes do not include (with sem execptions), such things ass (o) cooling/raw woter leaks, (b) Intrustons (roin infilerotion) and subsecuent leaks, (c) leaks inslds the tenk form but not through the tenk ll mer (eurfece leake, pipolins leaks, laaks ot the Joint for the overflow or flll lines, etc.), and (d) leaks from cateh tenks, diversion boxes, encescuments, otc.

In many cases, a laak was suppected lono before it was identified or confirmed. For example, reference (d) show that renk 261-U-104 was suppeted of leaking in 1956. The leak was "confli rmed" in 1961. This report lists the wessumd leaker" dote as 1961. Uaing preint stendards, Tank 261-U. 104 would have been declared as aseunad leaker in 1956. In 19ak, the critorifa desienst lons of "euspacted leaker," "questionable integrity," "confi rined leaker," "doclered leaker," "bordarl ine," and "dorwent," ware exrged into one category now reported as waseuned leaker "s see roference (ff) for explenstion of then, how long, and how fast som of the tenks leaked. It is highly likely that there have been undetected leaks frem single-shell tenks beceuse of the nature of their design and instrumentation.

There has been en offort in the past two years to reovaluate these leak volum estinates. Ouring the or 1993 funding roviaws, this reovaluntion of laak volums was given a priority which resulted in this ectivity no longer being fundad. The priority veraus funding will be reeveluated as part of the prior to FY 1994 budgot pleming.

The leak volume eatimate dote for theee tenks is before the "declered leaker" dote becsuse the tank was in " "suapected leaker" or "questionable integrity" status; however, a leak volume hed been estimated prior to the tank boing reclaseified.

The increasing rediation levels in drywalls and laterals associated with these three tanks could be indicative of continuing leak of novement of existing redionuclides in the soil. There is no conclusive way to confirm these doservations.

Mathods were used to estimate the leak volume from these 19 tanks based on the Mngmotion that their cumlative leakage is approximately the sem as for 18 of the 24 tanks identfifed in footnote (10). For more detalls see reference $(g)$. The total leak volum estimate for these tanks is 150 Kgal (rounded to the narest $10 \mathrm{Kgal}$ ), for en average of approximately $8 \mathrm{Kgal}$ for each of the 19 tanks. 


\section{TABLE I-1. SINGLE-SHELL TANK LEAK VOLUME ESTIMATES}

(Sheet 3 of 4 )

(8) The total has been rounced to the nearest $30 \mathrm{Kgol}$. Upperbound values were used in many cases in developing these estimates. It is likely that some of these tenks have not ectually leaked.

(9) Leak volum eatimate to based solely on dbeerved llauld level docreases in these tanks. This is constedered to be the moet accurate method for eatimating leak volumes.

(10) The curle content liated is as listed in the reference docuinent and is net dacayed to a conslatent date; therefore, a cumulative total is inappropriate.

(11) Tenk 261-C.101 experienced a llquid lovel docrease in the late 1960 s and was taken out of service and punped to " minim heel" in December 1969. In 1970, the tenk was claselffied as a

"quest toneble integrity" tank. Liquid levol date show decreases in Iovel throwehout the 1970s and the tenk was seltwall perped during the 1970s, ending in April 1979. The tank was rocleasifled as a "contirmed leaker" in Jenuary 1900. Sec reforence (q) and (s), refor to reforence (e) for information on the potential for there to have been loake frem other c-farm tanks (apecifically, C. 102, C-103, and $C-109$ ).

(12) These dates indicote then the tanks more ectually stabllized. In som cases, the officlal stabllizetion documents mre lesued at a later dote. 


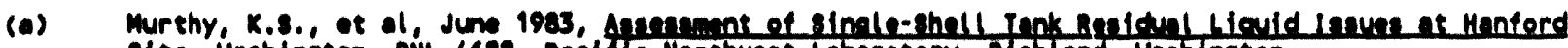

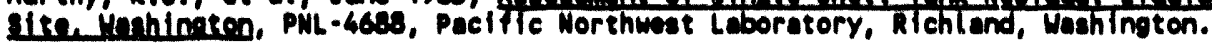

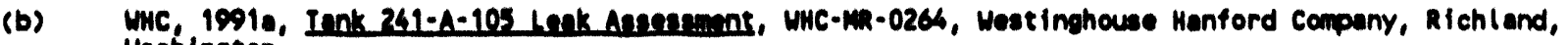
Washington.

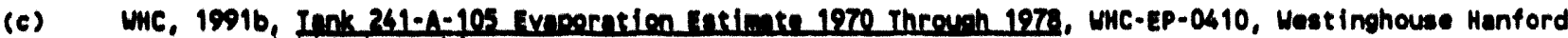
Comery, Richtand, Washington.

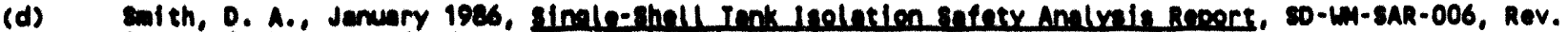
1. West inghouse Henford Company, RTehtand, Weshington.

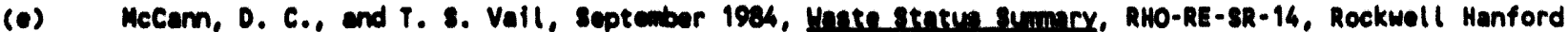
Oparations, Richland, Washington.

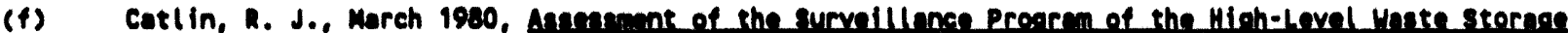

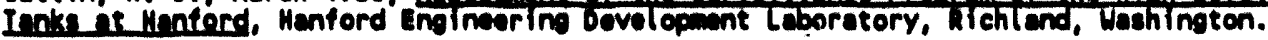

(g) Bawhardt, R. J., May 15, 1989, Letter to R. E. Garton, U.S. Department of Eneroy-Richland

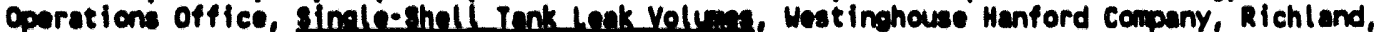
Washington.

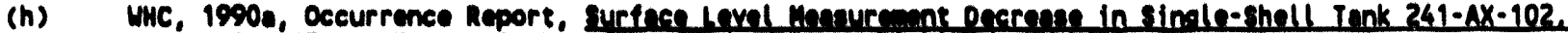
Mic-10-89-023-Tf-05, West inghouse Henford Company, Rlehtend, Washington.

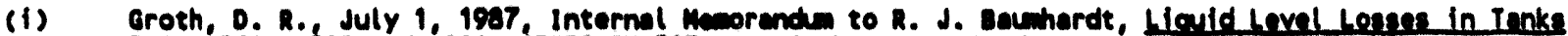
261-6-201,-202 end-204, 65950-87-517, Weat inchouse Menford Compeny, RTchtand, Washington.

(1) Groth, O. R. and O. C. Owens, May 15, 19a7, Internal Memorenden to J. H. Roecker, Ink 103-A Interefity evaluntion, Westinghouse Manford Capany, Richland, Washington.

(k) Cempell, 6. D. July 8, 1988, Internal Memorenden to R. K. Welty Enginanrine inventientioni Interetifinl liovid Level Deerene in Ienk 261-8x-10\%, 13331-88-416, West Inghouse Hanford Company, Richtend, Wastington.

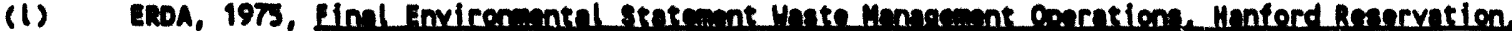

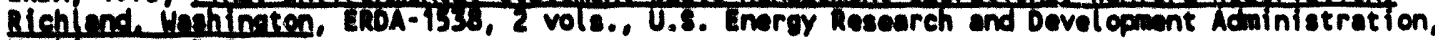
Washington, D.C.

WHC, 1992a, Innk 261-ex-109 Leak Amerement, WHC-Mr-0300, Westinghowse Manford Company, Richland, Washington.

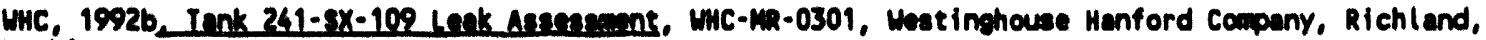
Uashington.

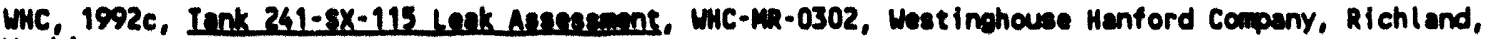
Washington.

WMC, 1992d, Oeceurrence Reoprt, wapparent Deerease in Liquid Level in single shell Underground storage Tank 261-T-TOT, Leak suppeted; Inveatigation Cont inuing," RL-WHC-TANKFARM-1992-0073, West inghowse Menford Compeny, Richlend, Washington.

(q) WHC-1990b, A Histery of the 200 Aren Ienk Finn, WHC-Mm-0132, Westinghouse Henford Company, Richland, washington.

(r) WHC, 1993, Occurrence Report, Single-shall Underaround Hagte storem Innk 241-8X-111 surfece Level

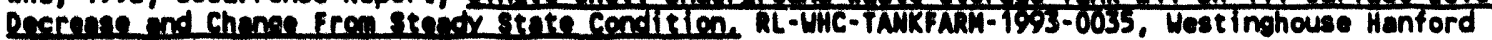
Compery, Rtchland, Washinoton.

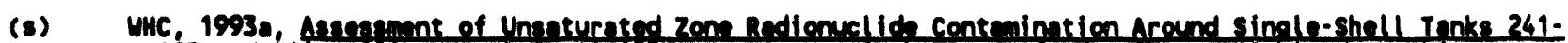

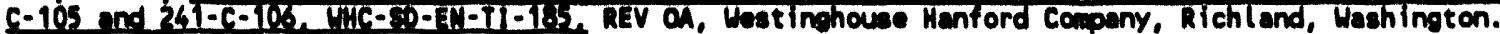


WHC-EP-0182-68

APPENDIX J

INTERIM STABILIZATION STATUS 
WHC-EP-0182-68

This page intentionally left blank. 
WHC-EP-0182-68

TABLE J-1. SINGLE-SHELL TANKS INTERIM STABILIZATION STATUS (Sheet 1 of 2) Novmber 30, 1993

\begin{tabular}{|c|c|c|c|c|c|c|c|c|c|c|c|}
\hline $\begin{array}{l}\text { Tank } \\
\text { Number }\end{array}$ & $\begin{array}{l}\text { Tank } \\
\text { Integrity }\end{array}$ & $\begin{array}{c}\text { Interim } \\
\text { Stabilized } \\
\text { Date (1) }\end{array}$ & $\begin{array}{l}\text { Stabilized } \\
\text { Method } \\
\text { (2)(3) }\end{array}$ & \begin{tabular}{|l} 
Tank \\
Number
\end{tabular} & $\begin{array}{l}\text { Tank } \\
\text { Integrity }\end{array}$ & \begin{tabular}{|c|} 
Interim \\
Stabilized \\
Date (1)
\end{tabular} & $\begin{array}{l}\text { Stabilized } \\
\text { Method } \\
\text { (2)(3) }\end{array}$ & $\begin{array}{l}\text { Tank } \\
\text { Number }\end{array}$ & $\begin{array}{c}\text { Tank } \\
\text { Integrity }\end{array}$ & \begin{tabular}{|c|} 
Interim \\
Stabilized \\
Date (1) \\
\end{tabular} & \begin{tabular}{|c|} 
Stabilized \\
Method \\
$(2)(3)$
\end{tabular} \\
\hline$\overline{A-101}$ & 8OUND & N NA & & (4x) & $5 \times 5 \times 3$ & ( & 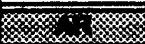 & $T-102$ & AETWD LKA & $11 / 78$ & AR \\
\hline$x \%$ & & & & $C-102$ & soUro & NMA & & Non & 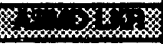 & 2 & $8 \%$ \\
\hline$A-103$ & ASNDLR & $\cos$ & A & $x$ & & $x$ & & $T-110$ & SOUND & $N A$ & \\
\hline 452 & & & & $c-104$ & EOUTD & and & $\mathrm{EN}$ & 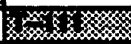 & $8 \times 3 \times 3$ & 30 & \\
\hline-105 & ASTDU UA & $07 r i v$ & AR & s.m. & & 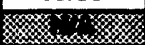 & & $T-112$ & 8OUND & $08 \% 1$ & AR \\
\hline 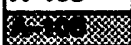 & 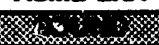 & & 3. & $c-100$ & SoUnd & NA & & 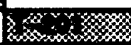 & 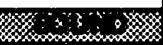 & 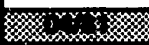 & 25 \\
\hline$\Delta x-101$ & soUro & NA & & & & & & $T-202$ & SOUND & 0.231 & $A R$ \\
\hline sastor & 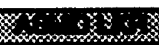 & & & $c-103$ & 8000 & $\cos 4$ & AR & $x$ & 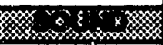 & 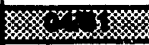 & 5 \\
\hline$\Delta x-100$ & 800010 & 0.57 & Ah & $2 x$ & & $x$ & 3 & $T-204$ & 8OUND & and & $A B$ \\
\hline 2 & 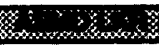 & 3 & 40 & $0-110$ & AESDLLA & N/A & & 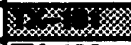 & $x_{0}^{3}$ & & 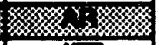 \\
\hline E-101 & ASTD DISA & 0.011 & EN & $x$ & $5 \times 98$ & $5 \times$ & & $T x-102$ & $800 \times 10$ & aras & JET \\
\hline & & & & $c-112$ & EOUTD & 00 & AR & $x^{2}=0$ & $8,5 \times 2$ & $8 \% 18$ & 叕: \\
\hline B-103 & Asर & 0200 & EN & sen & 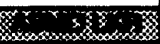 & & 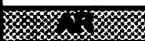 & $7 x-104$ & 8OUND & $00 \%$ & SN \\
\hline $1 \%$ & & & & $c-202$ & AEMDLOA & 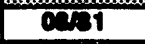 & AR & $\sec 28$ & 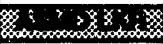 & 25 & 2 \\
\hline $8-105$ & ASTD WA & 124 & $\mathbf{A R}$ & $x=1$ & 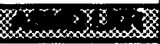 & 28 & 82 & $7 x-100$ & 80UNo & $000 / 23$ & JET \\
\hline$x$ & 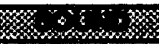 & & & $c-204$ & ASTDLTR & $00 \sqrt{2}$ & NR & $5 \times 3$ & 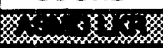 & $x+y$ & 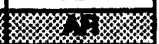 \\
\hline$B-107$ & ASNDLR & 0.06 & 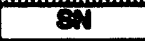 & $x$ & & 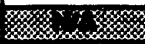 & & $7 x-100$ & 80 UND & $03 / 23$ & JET \\
\hline & & & & $\varepsilon-102$ & EOUTD & NA & & $1 \%$ & 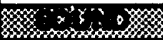 & 27 & 848 \\
\hline$B-100$ & EOUNO & 0405 & 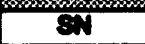 & & & $8 \times 3$ & & $7 x-110$ & ASTDLKA & $001 / 3$ & JET \\
\hline s. & $8 \times 18$ & & & $8-104$ & AENDLAR & 1224 & AA & $4 \times$ & 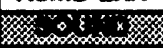 & 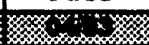 & 9 \\
\hline$B-111$ & ASMD LAR & 00,5 & Bin & & & & 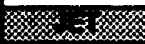 & $7 x-112$ & 8OUND & $04 \sqrt{23}$ & JET \\
\hline 68 & $8,3 \times 1$. & & & $8-100$ & coovo & WA & & $10^{2 x} 38$ & 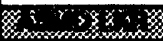 & 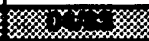 & $8=2$ \\
\hline$B-201$ & AENDLTA & con1 & AP & $x$ & & & & $7 x-114$ & ASMOLLR & $0,0 / 23$ & JET \\
\hline$x$ & 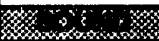 & & & $8-103$ & Couno & NA & & $x<x$ & 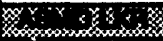 & $8 x$ & 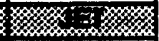 \\
\hline B-203 & ASTOLA & $\cos 4$ & AP & & & & & $7 x-110$ & ASTD LAR & 0,023 & JET \\
\hline$x$ & $2 x$ & & & $8-110$ & $800 \mathrm{Ko}$ & WA & & $x^{\prime 2 x}$ & sis & 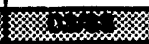 & 63 \\
\hline$B x-101$ & ASTOLAR & $\infty \pi$ & AR & & & & 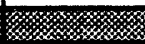 & $7 x-118$ & 80 UND & 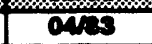 & JET \\
\hline 28 & $5 \sin 2$ & & & $E-112$ & EOUND & NA & & 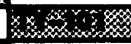 & 58 & 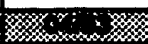 & 58 \\
\hline$B X-103$ & SOUKT: & $11 / 2$ & AA & 15 & & & & $T /-102$ & 8OUKD & 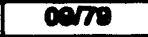 & AR \\
\hline 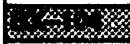 & $4: 3$ & & & $8 x-102$ & EOUTO & WA & & & & 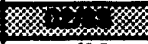 & 28 \\
\hline$B x-105$ & EOUTD & $\operatorname{cosin}$ & EN & 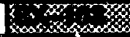 & & 15 & & $T y-104$ & AENO LKA & $11 / 13$ & $A R$ \\
\hline 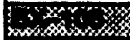 & & & & $8 x-104$ & ASTOLAR & WA & & $8 \times 4$ & 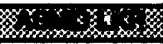 & 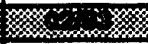 & 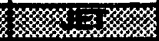 \\
\hline$B x-107$ & 80010 & $\infty$ & JET & $3 \times 3$ & $3 \times 1 \times$ & & & $T Y-100$ & ASMDLAR & $11 / 7$ & $A R$ \\
\hline 1.5. & 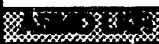 & & 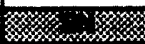 & $8 x-100$ & $800 \times 0$ & NA & & & $8,3 \times 3$ & wats & $8 x$ \\
\hline $8 x-100$ & SOUNO & 0000 & JET & $=x$ & & $x+3$ & & $4-102$ & SOUVWD & NA & \\
\hline 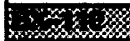 & $3 \times 3 \%$ & & 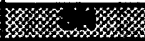 & $5 x-102$ & ASTDLA & 0,0 & AR & & 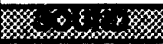 & $x$ & 必奴 \\
\hline$E x-111$ & ASTD LAA & NA & & $x \times 2$ & $8: 35$ & $8 \times 3$ & & $U-104$ & ASTD LKR & $10 \pi$ & A \\
\hline 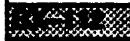 & & & & $6 x-110$ & AETDL LAA & $0, \pi$ & AA & & 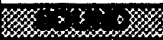 & 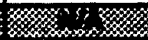 & \\
\hline$B Y-101$ & souno & 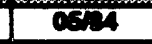 & JET & $2 \%$ & & 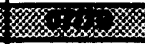 & 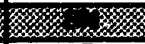 & $u-100$ & $800 \times 10$ & MA & \\
\hline & 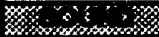 & & 嬨泣 & $8 x-112$ & AENOLKA & 0710 & AA & & & & m. \\
\hline BY-103 & ASND LRA & NA & & 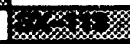 & & 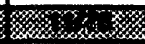 & & $0-103$ & 80UND & NA & \\
\hline & & & 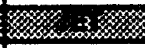 & $8 x-114$ & ASNOLG & $077 \%$ & AA & 1 & 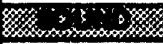 & ; & \\
\hline$B Y-105$ & AEMD LAR & WA & & 1238 & & 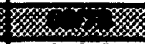 & & $0-110$ & AGMOUKR & $12 \sqrt{4}$ & $A R$ \\
\hline & & & & $T-101$ & AETDLA & ons & EN & 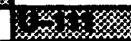 & 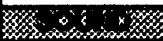 & (x) & \\
\hline$B Y-107$ & ASIDLA & $07 \pi$ & JET & $x$ & & & 28 & $u-112$ & AETDLR & $0 \% \pi$ & AR \\
\hline & 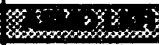 & & 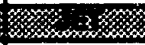 & $T-103$ & ASDLLA & $81 / 23$ & AR & $3 x=2$ & (x) & 2 & 8 \\
\hline$B Y-100$ & SOUND & WA & & & & s.m. & & $4-202$ & 8OUND & $0, \sqrt{10}$ & 8N \\
\hline $9 \times$ & & & $x_{3}$ & $T-106$ & $80 \mathrm{Non}$ & 0.57 & AA & & 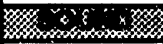 & $835 x$ & 85 \\
\hline BY-111 & 8OUND & 0105 & JET & 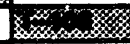 & & $x$ & sosin & $0-204$ & 8OUND & 0 arro & BN \\
\hline $4 x$ & 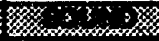 & $8 \times 12$ & 3. & $T-107$ & AS DOUA & NA & & & & & \\
\hline 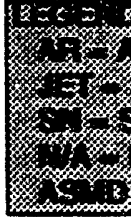 & $\frac{1}{x+2}$ & $\frac{1}{4 \times 1}$ & s. & কে & & & & \multicolumn{3}{|c|}{$\begin{array}{l}\text { Interim Stabilized Tanks } \\
\text { Not Yet Interim Stabilized } \\
\text { Total Single-Shell Tanks }\end{array}$} & $\begin{array}{r}106 \\
43 \\
\end{array}$ \\
\hline
\end{tabular}

Footnotes: See next page 
TABLE J-1. SINGLE-SHELL TANKS INTERIM STABILIZATION STATUS

(sheet 2 of 2)

\section{Footnotes:}

Note: Further information on the data below can be found in WHC-SD-RE-TI-178, "Single-Shell Tank stabilization Record," dated 1991. This document is currently being revised.

(1) These dates indicate then the tanks mere actually stabilized. In some cases, the official stabilization documents were issued at a later date.

(2) The following six tanks do not meet current established supernatant and interstitial liquid stabilization criteris, but did meet the criteria in existence when they were declared interim stabilized :

$$
\begin{aligned}
& \text { 8-104, } 110,111 \\
& T-102,112 \\
& U-110
\end{aligned}
$$

(3)

Interim Stabilization date are missing on four tanks. These tanks were Administratively Interim Stabilized.

$$
\text { B-201, T-102, 112, } 201
$$




\section{Number of copies}

OFFSITE - USA

Congress of the United States

House of Representatives

1111 Longworth Building

Washington, DC 20515-3703

Ron Wyden, Member of Congress, 3rd District Josh Kardon, Legislative Director

U. S. Department of Energy-Headquarters

1000 Independence Avenue, SW

Washington, D. C. 20585

Emile Bernard

H. Calley

H. Eckert

Teresa Fryberger

Sherry Gibson

A. Griffith

L. Gunn

D. Gupta

Kenneth Lang

J. C. Lehr

G. Mellinger

C. O'Dell

D. Pepson

J. C. Tseng

S. Woodbury

$\begin{array}{ll}E M-50 & \text { TREV II } \\ E M-36 & \text { TREV II } \\ \text { EM-37 } & \text { TREV II } \\ \text { EM-542 } & \text { TREV II } \\ \text { EM-55 } & \text { TREV II } \\ \text { EM-36 } & \text { TREV I I } / 341 \\ E M-36 & \text { TREV I I } \\ E M-36 & \text { TREV II } \\ E M-36 & \text { TREV II } \\ \text { EM-442 } & \text { TREV II } / 160 \\ E M-36 & \text { TREV II } \\ E M-36 & \text { TREV II } \\ \text { EM-36 } & \text { TREV II } \\ \text { EM-36 } & \text { TREV II } / 364 \\ E H-222 & \text { FORS/3G-092 }\end{array}$

19901 Germantown Rd, Germantown, MD 20585
R. Lasky
J. Psaras
EH-32.1 GTN/G-115
P. Worthington
NS-20 GTN
NS-20 GTN

U. S. Department of Energy - Oak Ridge Operations Office P. 0. Box 2001

Oak Ridge, TN 37831

W. D. Adams EW-40

7 U. S. Department of Energy - Savannah River Site P. 0. Box A

Aiken, SC 29808

$\begin{array}{ll}\text { C. Anderson } & 707-\mathrm{H} \\ \text { Michael Chandler } & 703-\mathrm{H} \\ \text { Mazen Shurrab } & 704-\mathrm{H}\end{array}$

T. C. Temple 
MHC-EP-0182-68

$$
\text { Distribution - continued }
$$

L. Sjostrom

W. R. West

V. Wheeler

704-8H

704-S

U. S. Environmental Protection Agency

Region 10

712 Swift Boulevard, Suite 5

Richland, WA 99352

D. R. Sherwood

Nashington State Department of Ecology Nuclear \& Mixed Waste Management Program P.0. Box 47600

01 ympia, WA 98504-7600

M. T. Gordon

M. Lerchan

Scott McKinney

R. Stanley

Library

7601 W. Clearwater \#102

Kennewick, WA 99336

S. V. Moore

Office Library

Mashington State Departipent of Health Radiation Protection Section Industrial Park Building 5, L.E-13

Olympia, WA 98504

\section{A. Conkl in}

General Accounting Office

P. 0. Box 321

Richland, WA 99352

C. R. Abraham

Oregon State Department of Energy 625 Marion St. N.E.

Salem, OR 97310

Janet Franco

Oregon State Mater Resources Department Ground Water Hanford Studies 3850 Portland Road

Salem, OR 97310

R. 0. Patt 


\section{Distribution - continued}

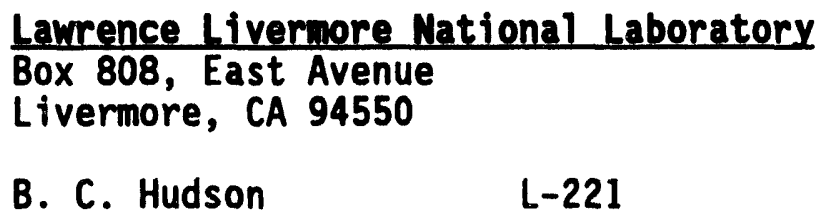

B. C. Hudson

Oak Ridge National Laboratory

P. 0. Box 2009

Oak Ridge, TN 37831-6385

C. Forsberg

MS-6495

T. S. Kress

MS-8088

Bldg 9108

Chemical Technology Division

P. 0. Box 2008

Emory D. Collins

C. Phil McGinnis

Dr. Jack Watson

Los Alamos National Laboratory

P. 0. Box 1663

Los Alamos, NM 87545

Stephen Agnew

Group INC-14

Phyllis Baca

$C-346$

T. Larson

$\mathrm{J}-514$

Sylvia Lee

A. Nuels

H. Sullivan

C-915

K-557

Dr. Reed Jensen

$N-6$

$N-6$

$\mathrm{J}-565$

Brookhaven National Laboratory Upton, NY 11973

K. K. Bandyopadhyay, B1dg 475-C

M. K. Kaisser, B1dg 475-C

P. D. Kalb, Bidg. 703

M. Reich, Bldg 475-C

J. R. Weeks, B1dg 197-C

1 Brookhaven National Laboratory 1409 Jan Drive

Wilmington, DE 19803

Michael Streicher 


\section{WHC-EP-0182-68 \\ Distribution - continued}

2

Argonne Mational Laboratory

9700 South Cass Avenue

Argonne, IL 60439

Dr. Martin Steindler

Dr. George Vandergrift

3

Sandia National Laboratories

1515 Eubank, NE

P. 0. Box 5800

Aibuquerque, NM 87185

Scott Slezak, Division 6471

Leon D. Chapman, Program Manager Industrial Waste Reduction Program

Dr. Margaret Chu, Organ $\$ 6622$

Massachusetts Institute of Technology

77 Massachusetts Avenue

Cambridge, MA 02139

Mujid S. Kazimi

Professor and Head

Department of Nuclear Engineering

2

BDin International. Inc.

20030 Century Blvd, Suite 101

Germantown, MD 20874

P. Kiang

K. J. Mahoney

3

SAIC

Trevion 1, Suite 300

20300 Century Blvd.

Germantown, MD 20874

J. Bunting

J. R. Pearring

R. A. Wullaert

1

102 Windham Road

Oak Ridge, TN 37830

D. 0. Campbel1

1

1845 Terminal Drive, Suite 130

Richl and, WA 99352

J. Mishima 
MHC-EP-0182-68

Distribution - continued

555 Quince Orchard Road

Gatthersburg, MD 20878

Paul Szerszen

1

Harvard University

295 Upl and Avenue

Newton Highlands, MA 02161

Melvin First

1

Syracuse University

334 Hinds Hall

Chemical Engineering \& Materials Science Department

Syracuse, NY 13244

Dr. Larry Tavlarides

Confederated Iribes, Umatilla Indian Reservation

P. 0. Box 638

Pendieton, OR 97801

Rick George

Mest Valley Nuclear Services Co.

P. 0. Box 191

West Valley, NY 14171

K. K. Gupta

MS-49

S. Ketola

MS-191

D. K. Ploetz

MS-305

Ram Shukla

Don Stroud

K \& Engineering \& Consulting Corporation

Suite 500

2001 L St. NW

Washington, D. C. 20036

Ryan Gill

4

Defense Nuclear Facilities Safety Board

625 Indiana Ave, N. W., Suite 700

Washington, D. C. 20004

Lester Clemons

Suite 700

Timothy Dwyer

Steven Stokes

Richard Tontodonato 
WHC-EP-0182-68

\section{Distribution - continuod}

Mestinghouse Id the Nualenr corporation

P. 0. Box 4000

Idaho Falls, ID 83404-4000

B. Grlebenow

MS-5104

A. P. Hoskins

MS-5217

Dr. Terry Todd

C. Abrams

1987 Virginta Drive

Idaho Falls, ID 83404

1

Fred N. Carlson

6965 North 5th West

Idaho Falls, ID 83401

1

Donald T. Oakley

555 Quince Oncliard Road

Gaithersburg, MD 20878

Dr. A. Veletsos

Department of Civil Englneering

Rice University

P. O. Box 1892

Houston, TX 77252

Uestinghouse Electric Corporation

1801 K Street $N$, 8th floor

Washington DC, 20006

Kevin Btllings

Mestinghouse interiels Co..nonny of Ohto

P. 0. Box 398704

Cincinnati OH 45239-8704

David L. Jacoboskt

Senior Engineer, Technology Demonstration

\section{Mestinghouse sovannh River Company}

P. 0 . Box 616

Aiken, SC 29802

D. M. Barnes, 773-41A

J. R. Chandler, 703-H

P. d'Entremont

F. G. McNatt, 704-8A

Dr. Major Thompson

Inst itute for Eneray and Environmental Reseach

6935 Laurel Avenue

Takoma Park, MD 20912

Or. Arjun Makhijant, President

$$
\text { Distr-6 }
$$




\section{Distribution - continued}

SPAR_Anrosence lted.

20 Avon Meadow Lane, Sutte 220

Avon, CT 06001

Peter W. Kruse

Advanced Technology Systems Division

Rotrone Robotics. Ince.

2425 Liberty Ave

Pittsburgh, PA 15222-4639

David W. White

12

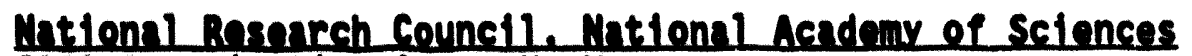

2101 Constitution Ave., N. W.

Washington D. C. 20418

Robert S. Andrews, Senior Staff Officer

Board on Radloactive Waste Management

Converse Consultints

$18 \mathrm{~W}$. Mercer Street, Suite 300

Seattle, WA 98119

David Stanley

1

Broun 1 Caldull

100 W. Harrison

Seattle, WA 98119

Hal Cooper

Benton County Department of Energency Management

P.0. Box 6144

Kennewick, WA 99336

Gary Pira

1

Boyay Morthmest Inc.

660 Swift, Suite D

Richland, WA 99352

T. J. McLaughl in

Omea Environmental Technoloay

655 Montgomery Street, Suite 1000

San Francisco, CA 94111

Mike Batley 


\section{Distribution - continued}

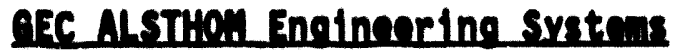

P. 0. Box 1274

Richland, WA 99352

J. W. Riddington,

Vice President, Nuclear Marketing

T. S. Elleman

North Carolina State University

Department of Nuclear Energy

P. O. Box 7909

Raleigh, NC 27606

Mike Lingle

Stone \& Webster

7677 E. Berry Ave

Englewood, CA 80111

1

Bryant Mather

Corps of Engineers

WESSV-Z

3909 Halls Ferry Rd

Vicksburg, MS 39180-6199

Paul Shewmon

Prof. Metallurgical Engineer

Ohio State University

2477 Lytham Road

Columbus, OH $\mathbf{4 3 2 2 0}$

Mnste Manogement Externel Advisory Comittee Nembers

Dr. Frank L. Parker

Professor of Environmental and Water Resources Engineering Vanderbilt University

P. 0. Box 1596, Station B

Nashville, TN 37235

Or. Bruce R. Kowalski

Professor of Chemistry, Co-director of Center for Process

Analytical Chemistry

University of Washington

Chemistry Department, Bidg 10

Seattle, WA 98195

Dr. Greg R. Choppin

Professor of Chemistry

Florida State University

Department of Chemistry, B-164

Tallahassee, FL 32306

Dr. Chester Grelecki

President, Chief Scientist

Hazards Research Corporation 


\section{MHC-EP-0182-68 \\ Distribution - continued}

200 Valley Road, Suite 301

Mt. Arlington, NJ 07856

Or. Alfred Schneider

Professor Meritus of Nuclear Engineering

Georgia Institute of Technology

5005 Hidden Branches Dr.

Dunwoody, GA 30338

Dr. Gary Powers

President

Design Sctence, Inc.

163 Witherow Road

Sewickley, PA 15143

Joseph S. Byrd

University of South Carolina

Department of Electrical and Computer Engineering

Swearingen Engineering Center

Columbia, SC 29208

William R. Prindle

1556 Crestline Drive

Santa Barbara, CA 93105

2

Ame inboratory

7 Spedding Hall

Iowa State University

Anes, IA 50011

Bill Haas

R. B. Thompson

1

RXK Lted.

16404 Smokey Pt. Blvd, Suite 303

Arlington, WA 98223

Chris Reno

1

MATEC

8320 Centerbrook P1 ace

Alexandria, VA 22308

Stan Blacker

1

Enainenrine-scionce. Inc.

1955 Jadwin Ave, Suite 470

Richl and, WA 99352

Matt Sakach 
MHC-EP-0182-68

Distribution - continued

EPAsco sorviges ince

1201 Jadwin Avenue, Suite 202

Richland, WA 99352-3429

F. J. Young

1

III. Syctems. Inc.

3481 Dayton-Xenta Road

Dayton, OH 45431-0299

E. McDantel

1

Nuciner Consulting services. Ince

7000 Huntley Road

P. 0. Box 29151

Columbus, $\mathrm{OH} 43229$

Dr. J. Louts Kovach

1

Bettelle Leoretorins

505 King Avenue

Columbus, OH 43201-2693

Rob Taylor Jr., P.E.

Rm 13-6-016

Portland emeral Flectric co.

121 S. H. Salmon St.

Portland, OR 97204-2991

Wayne Lei, 3WTCBRO5

1

Meptune \& Company

1505 15th St., Suite B

Los Alamos, NM 87544

Randy Ryti

John Hookins University

1714 Eutaw Place

Baltimore, MD 21217

Morton Corn

Roberts Enqinoering Services. IXC.

1980 East Ocean Boulevard

Stuart, FL 34916

Dr. Paul Roberts

Columbie River United Technical Consultant

P. 0. Box 912

Bingen, WA 98605

Gregory de Bruler

Distr-10 
MHC-EP-0182-68

Distribution - continued

Eovernment Accountability Project

West Coast Office

1402 Third Avenue, Suite 1215

Seattle, WA 98101

Thomas E. Carpenter, Director

1

Henrt of Ampice Northwest

1305 Fourth Avenue

Cobb Building Suite 208

Seattle, WA 98101

Gerald M. Pollet, Executive Director

1

Dr. Paul Wang

Ames Laboratory

106 Spedding Hall

Iowa State University

Anes, 1050011

1

Dr. Viorica Lopez-Avila

Midwest Research Institute

625-B Clyde Ave

Mountain View, CA 94043

1

Les Alnos Technical Associates

8633 W. Gage Bivd.

Kennewick, WA 99336

D. S. Delorenzo

OFFSITE - FOREIAN

1

British Nuclear Funls ltd

Risley Warrington

Cheshire WA3 6AS

United Kingdom

Howard A. Edwards

1

Ricardo Hitec litd

Club street Works, Bamber Bridge

Preston, PR5 6FN

United Kingdom

P. K. J. Smith

1 Telerobot

Consorzto Telerobot

Via Hermada 6

16154 Genova, Italy

Bruno Sessarego

Distr-11 


\section{WHC-EP-0182-68 \\ Distribution - continued}

1

SEY

1 , rue des Herons, Montigny-C-Bretonneux

78132 Saint-Quent in-en-Yvel ines Cedex,

France

Serge Merlin

2

CEA - SAclay

DCC/DIR

Ba't 121

91190 GIF/Yvette Cedex

France

G. Baudin

R. Atabek

1

Hans Malischilling GabH

D-7778 Markdorf/Bodensee

Germany

Wolfgang Wal ischmiller

OMSITE

J. J. Anttonen

G. E. Bishop

K. W. Bracken

S. T. Burnum

R. C. Cullison

J. J. Davis

L. Erickson

R. E. Gerton

M. Gl asper

W. F. Hendrickson

R. L. Higgins

R. D. Hildebrand

P. E. LaMont

T. Noble

R. L. Person

L. E. Petersen

G. W. Rosenwald

G. H. Sanders

E. J. Senat

A. B. Sidpara

A. D. Toth

J. K. Yerxa

Reading Room
R3-73

R3-72

R3-73

R3-74

A5-55

R3-74

R3-74

R3-72

R3-72

R3-72

R3-72

A5-55

R3-74

R3-72

R3-72

R3-72

R3-72

R3-74

R3-72

R3-73

R3-72

A5-15

A1 -65 
WHC-EP-0182-68

Distribution - continued

BNFL INC.

Dr. Mike Mckeon

G3-02

Stone \&ebster Engineering Co.

E. L. Richards

R2-83

2

MATEC

J. Janus

G6-18

L. Soler

A4-35

\section{EBASCO}
C. T. Anderson
G3-02

Pacific Northwest Laboratories

D. N. Anderson

K7-34

W. J. Apley

D. B. Baird

R. M. Bean

K1-73

D. W. Bennett

K7-34

P. R. Bredt

P8-08

K5-17

S. A. Bryan

P7-25

L. L. Burger

P7-25

J. B. Colson

P7-25

J. F. Fletcher

K5-10

E. A. Flores

K7-97

L. K. Holton Jr.

K3-08

$V$. L. Hunter

P7-43

P. R. Hrma

J. Janata

K7-94

P8-37

B. M. Johnson

K2-12

K1-78

E. O. Jones

P8-38

D. E. Larson

G3-02

S. G. Mckinley

P7-22

A. L. Mitchell

K7-94

L. G. Morgan

P7-35

B. E. Opitz

K6-81

M. S. Peffers

W. G. Richmond

K7-94

P7-41

J. M. Robbins

P7-22

R. D. Scheele

P7-25

E. A. Schmieman

K6-14

R. C. Schrotke

P. A. Scott

P7-18

P7-19

J. C. Spanner

K2-05

J. L. Straalsund

K1-79

K. L. Steinmaus

K6-84

J. L. Swanson

P7-25

K. M. Tominey

K7-97 


\section{Distribution - continued}

R. S. Wegeng

K7-97

P. D. Whitney

K7-34

T. W. Wood

K6-47 Sciences Richland/Kaiser Enqineers Hanford

A. T. Alstad

W. T. Alumkal

R. P. Anantatmula

J. D. Anderson

J. N. Appel

I. J. Aust in

H. Babad

J. K. Bajwa

A. D. Bates

P. K. Bhatia

T. J. Bander

L. L. Barry

G. D. Bazinet

D. L. Becker

D. B. Bechtold

R. V. Berg

M. V. Berriochoa

B. D. Biddle

K. R. Birney

D. L. Bjorkiund

J. E. Bjorklund

R. J. Bl anchard

D. C. Board

K. D. Boomer

G. L. Borsheim

V. C. Boyles

D. A. Bragg

D. R. Bratzel

W. R. Brooksher

R. G. Brown

S. K. Burden

J. H. Bussell

J. A. Caggiano Jr

J. W. Carey

R. J. Cash

T. Chiao

G. Christensen

K. L. Chubb

K. J. Cleveland

G. J. Coleman

J. C. Conner

R. B. Conrad

W. B. Cook

F. M. Coony

W. L. Cowley

C. Crawford
R1-49

R2-52

R2-11

N3-11

S4-58

T4-01

R2-78

H4-63

T3-01

S4-58

HO-33

RI-67

L4-71

H5-57

T6-09

R4-02

B3-30

(6) $55-14$

HO-40

S6-01

R1-62

R1-17

S1-57

H5-49

R2-11

R1-49

R1-49

L5-31

L4-01

R2-14

S4-55

L7-06

H6-06

S5-07

R2-78

LO-06

H4-21

L6-86

S3-10

T4-07

H4-61

H5-09

S5-20

H6-07

H4-61

R3-01 


\section{Distribution - continued}

N. R. Croskrey

R1-30

G. M. Crummel

RI-51

J. M. Cruse

L5-63

D. S. Cunningham

SO-02

S. A. Davidson

J. S. Davis

K6-26

S. J. Dechter

H4-64

C. DeFigh-Price

R2-54

T. A. Demitruk

R2-31

C. J. Denson

H5-36

D. R. Dickinson

L4-95

S. E. Dieterle

ᄂ5-31

L. F. Dougherty

S2-20

G. L. Dunford

H4-63

R. F. Eggers

R1-51

E. G. Elfner

S4-58

D. R. Ellingson

S2-24

F. W. Ellis

H5-37

D. B. Engelman

B4-52

S. D. Estey

W. G. Farley

R2-18

R2-11

H4-62

J. E. Fasso Jr.

S3-10

K. O. Fein

H4-63

L. A. Fort

S4-57

K. D. Fowler

R2-11

S. B. Fowler

LO-24

G. L. Fox, Jr.

L5-01

C. R. Fox

S4-60

G. T. Frater

R1-51

J. R. Freeman-Poll ard

H6-03

R. T. French

E6-61

J. C. Fulton

R2-31

K. A. Gasper

R2-08

G. J. Gauck

RI-51

C. J. Geier

R2-50

P. W. Gibbons

S4-58

R. L. Gilchrist

L5-63

D. A. Gilles

S2-14

S. D. Godfrey

R1-51

D. E. Good

S3-97

D. J. Green

H5-53

A. Greenberg

S2-66

P. R. Golberg

B4-08

P. Greenbaum

S5-20

W. T. Gretsinger

R4-01

J. M. Grigsby

H4-62

R. D. Gustavson

R1-51

K. D. Haggerty

T4-09

L. E. Hall

E6-25

V. W. Hall

R2-85

G6-04

C. S. Haller

T6-02

K. W. Hamilton

L4-71

B. M. Hanton (30)

R1-80

Distr-15 
J. M. Hanson

H. D. Harmon

M. S. Harrington

J. P. Harris III

G. A. Harvey

F. J. Heard

D. A. Healey

J. M. Henderson

D. W. Hendrickson

E. G. Hess

M. C. Higginson

B. M. Hisaw

M. J. Holm

B. A. Holmberg

J. D. Hopkins

B. K. Horsager

J. H. Huber

J. L. Huckaby

A. L. Huegel

J. V. Hurley

J. E. Irvin

M. N. Islam

M. T. Jansky

G. D. Johnson

J. L. Juette

R. A. Karnesky

J. R. Kasper

D. L. Kelly

R. A. Kirkbride

C. A. Kuhlman

N. W. Kirch

D. B. Klos

A. G. Krasopoulos

M. Kummerer

M. J. Kupfer

E. C. Ladd

D. R. Lance

J. Lee

D. L. Lenseigne

J. M. Light

D. C. Lini

B. H. Lueck Jr.

P. J. Mackey

G. T. Maclean

M. K. Mahaffey

R. M. Marusich

V. D. Maupin

T. B. McCall

J. D. McCormack

K. S. McCullough

M. A. McLaughl in

J. P. Menard

W. C. Miller

N. J. Milliken
R2-85

R2-52

B4-53

S4-55

B4-52

HO-34

T4-07

S4-55

L5-55

R3-09

A4-25

R1-62

R1-80

G4-02

R2-11

B5-24

R1-49

R2-11

E6-31

R4-02

R2-85

R3-08

H6-26

R2-78

G6-56

HO-39

R2-54

S5-20

S4-58

B3-30

R2-11

SO-14

A5-55

H4-62

H5-49

R1-19

SO-09

R2-36

R2-75

B4-08

H3-56

R3-12

B3-15

S4-58

L4-73

H4-60

$\mathrm{N} 1-73$

HO-33

L5-31

H4-70

H5-09

R2-40

S4-55

H4-62 


\section{Distribution - continued}

\begin{tabular}{|c|c|}
\hline 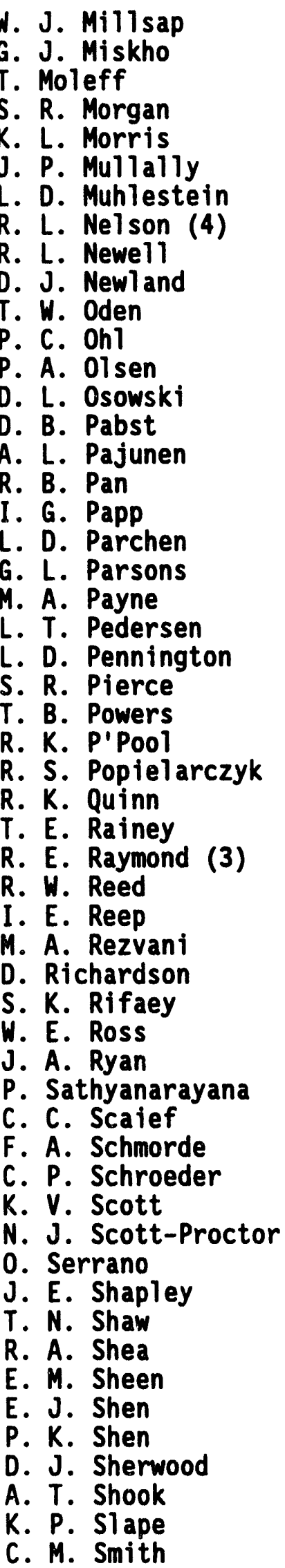 & 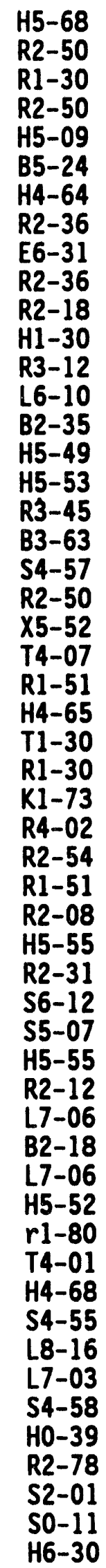 \\
\hline
\end{tabular}




\section{Distribution - continued}

S. G. Spencer

R1-30

S. M. Stah1

H4-61

E. G. Stephan

A3-74

B. E. Stapley

R4-02

R. R. Stickney

R4-02

D. G. Sutherl and

L4-72

J. P. Summerhays

R2-88

L. M. Swanson

H5 -49

J. F. Thompson

H5-68

J. D. Thomson

S. R. Tifft

J. A. Tilden (2)

R1-30

H. Toffer

H6-26

T. T. Tran

L6-12

A. L. Trego

HO-38

J. W. Tritz

L7-04

B3-02

D. P. Trott

B1-32

D. A. Turner

B1-32

C. J. Udell

R2-78

R. E. Van der Cook

L6-12

R. J. Van Vieet

S6-17

D. T. Vladimiroff

H4-62

J. A. Voogd

G7-01

R4-03

O. S. Wang

R2-78

D. L. Wegener

R. K. Weity

G. T. Wells

R1-62

R1-80

R. Whitman

H6-26

J. H. Wicks

H5-49

T4-07

D. D. Wiggins

R1-49

M. E. Witherspoon

E6-61

D. D. Wodrich

R2-85

R. D. Wojtasek

H6-27

W. R. Wrzesinski

R3-74

P. A. Young

R2-14

B. D. Zimmerman

LO-06

SDPC Docket File (2) H5-36 272-AW Shift Office S5-04

Central Files (2) L8-04

Tank Farms Info Center R1-20

Information Release Administration (3) R1-08

Env Data Mgmt Center H4-22

RL/TWRS Library

R3-72 

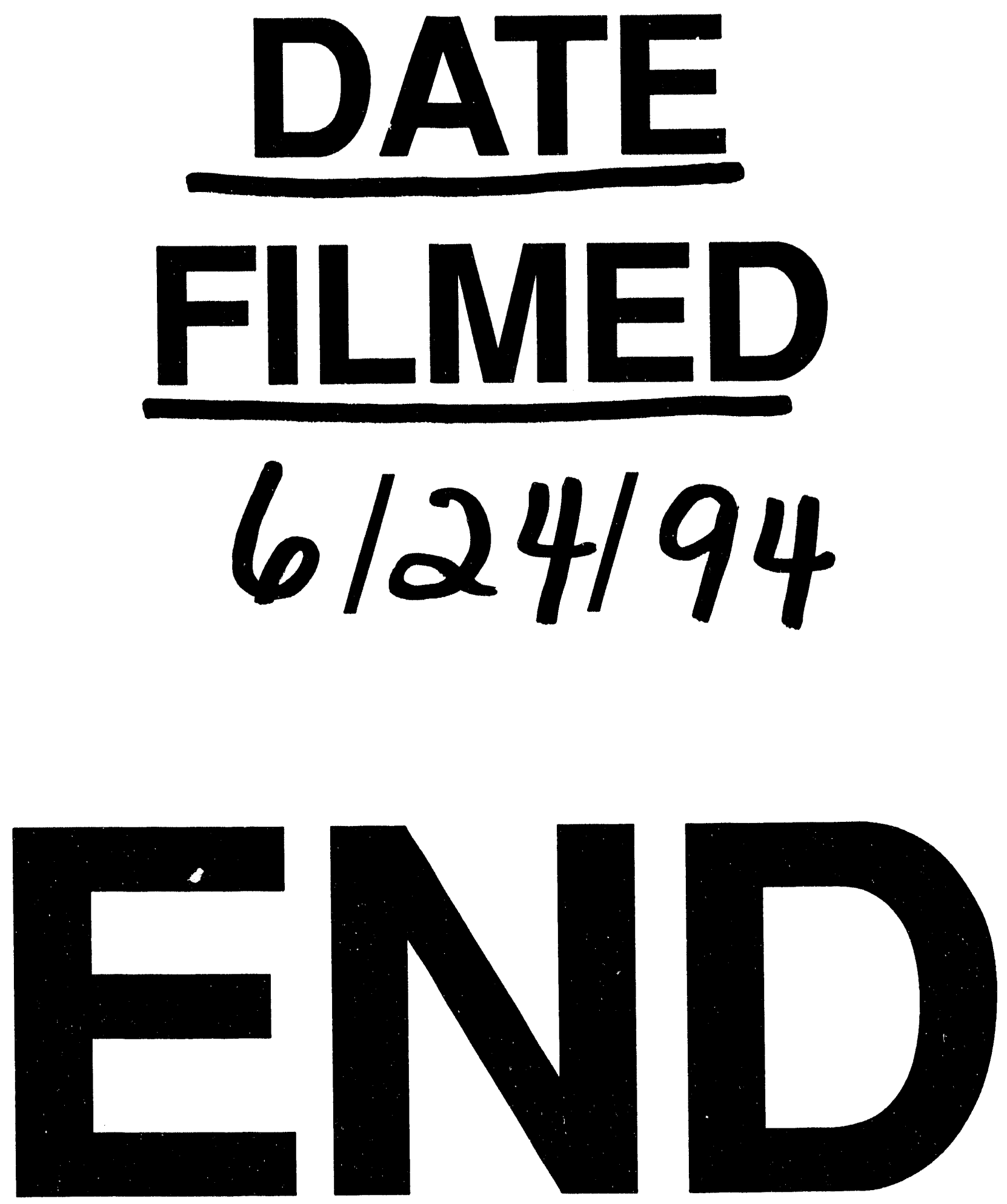
